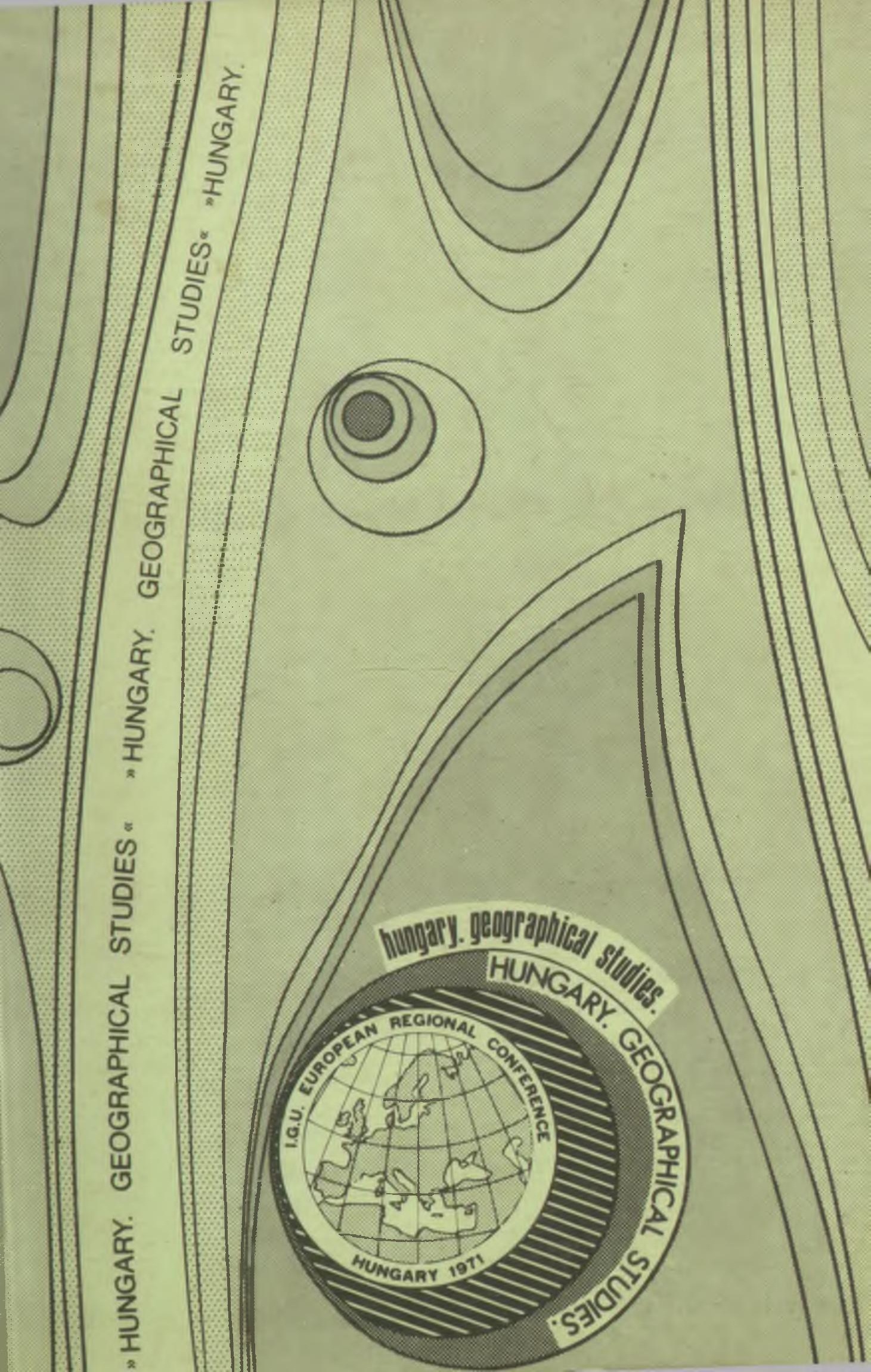



GEOGRAPHICAL STUDIES 
HUNGARY

GEOGRAPHICAL STUDIES

Edited by

MARTON PECSI

GYORGY ENYEDI

SANDOR MAROSI 


\section{Hungary}

Geographical Studies

INTERNATIONAL GEOGRAPHICAL UNION

EUROPEAN REGIONAL CONFERENCE

BUDAPEST 1971 
Translation revised by MARY VOLGYES

Title-page designed by L. Ballonyi 704314 MTA KESZ Sokszorositó. F. v.: Szabó Gyula 


\section{CONTENTS}

Preface

\section{Part One}

Physical Geography

Pécsi, M., Somogyi, S. and Jakucs, P.

Landscape units and their types in Hungary

Bacsó, N.

The climate of Hungary

Pécsi, M. and Somogyi, S.

The hydrography of Hungary

Pécsi, M. and Jakucs, $P$.

The natural vegetation of Hungary ...................................................... 109

Pécsi, M. and Góczán, L.

The soils of Hungary

\section{Part two \\ Economic Geography}

Enyedi, Gy.

Regional development of the Hungarian national economy

Krajkó, Gy.

The economic regions of Hungary

Borai, A.

The territorial distribution of energy resources in Hungary

Antal, Z. and Perczel, Gy.

Some economic geographical problems of Hungary's chemical industry

Bernàt, $T$.

Regional changes in Hungarian agriculture

Asztalos, I.

Regional problems of stock-breeding in Hungary ..................................... 205

Lettrich, $\boldsymbol{E}$.

Urbanization trends in Hungary

Gertig, B.

The tourist trade in the Balaton resort district 

This volume has been compiled in order to give the participants in the 1971 European Regional Conference of the International Geographical Union a brief account of geography of the organizing country and the recent results of Hungarian geographical research.

The size of the volume did not allow either the systematic publication of the complete geography of Hungary, nor thematical completeness. In addition, the compilation cannot offer a complete picture of the present state of Hungarian geographical research, as well as the results especially in the field of applied geography.

If the reader strives for a more complete knowledge of the results of Hungarian geographical research, we should like to call his attention, on the one hand to the other publications of the Regional Conference - the lectures to be delivered on Hungary; and on the other hand to the following publications: Pécsi, M. and Sárfalvi, B. Die Geographie Ungarns (1962); Kengriya (1962); The Geography of Hungary (1962); the volumes of the series, Studies in Gegoraphy in Hungary; the quarterly of the 100year-old Hungarian Geographical Society (Földrajzi Közlemenyek = Geographical Review); the quarterly of the 20-year-old Geographical Research Institute of the Hungarian Academy of Sciences (Földrajzi Ertesitö = Geographical Bulletin). In addition, the studies have summaries in English, Russian, French or German. The Hungarian universities also publish geographical works in foreign languages (Annales Universitatis Scientiarium Budapestiensis de R. Eötrös Nominatae, Sectio Geographica; Acta Universitatis Debreceniensis de Ludovico Kossuth Nominatae. Series Geographica, Geologica et Meteorologica; Acta Universitatis Szegediensis, Pars Geographica Scientiarium Naturalium. Acta Geographica). Some of the special books appearing in Hungarian (the series Földrajzi Monográfiák = Geographical Monographs; Földrajzi Tanulmányok = Geographical Studies and the handbooks) also have summaries in foreign languages, or are published in a special series (Hungarian Academy of Sciences, Institute of Geography-Abstracts).

The related sciences also display a comprehensive activity in the field of publication, partly in foreign languages. The volume giving a comprehensive picture of the country not only from geographical point of view. but from historical, social, economic and cultural aspects is the Information Hungary (Erdei, F. ed. 1968). Therefore, we have given only the most 
important references to the studies published in the volume, leaving to the interest of the reader the degree of getting acquainted with Hungary and the Hungarian geography.

We greet the foreign participants in the European Regional Conference of the International Geographical Union. It is our hope that after spending pleasant and useful time in Hungary, and after becoming acquainted with the geographical and social conditions of our contry, our hospitable people, as well as gaining impressions and useful professional experiences, they will return home to their everyday work after the Conference with the desire of meeting us again. 


\section{PART ONE \\ PHYSICAL GEOGRAPHY}





\section{LANDSCAPE UNITS AND THEIR TYPES IN HUNGARY}

M. PÉCSI - S. SOMOGYI - P. JAKUCS

\section{Interpretation and methodology}

In Hungary neither landscapes totally preserved in their natural conditions, nor original physiography environments can be spoken of. Therefore, it is obvious that the environment-altering effects of society cannot be separated from the concrete investigations of the landscape.

Furthermore. so far the real landscape or natural environment affected by the human society has been investigated only from the viewpoint of the physical landscape-forming agents by a considerable part of physical geographers. A landscape unit, explained in such a way, is called a "physiographic landscape", which implies the reconstruction of the original natural environment.

Some physical geographers, - including the authors - consider a landscape to be a unit of the geosphere which is the result of the natural and anthropogenic factors, and kinetic processes affecting one another by continuous mutual alteration. Consequently, it is necessary for physical geography to extend its investigations over the social and economic phenomena acting on the environment. The human activity uses and considerably transforms the physiographic landscape, though in the transformed region the natural elements will not cease acting according to the laws of nature, and the anthropogenic factors will not fail to obey the social laws.

This relationship implies, among other things, that the investigators of economic regions also have to scrutinize the physical landscape-forming agents.

In the course of research work, a complex approach to the landscape and to its evaluation is necessary for the more progressive economic activity of present time. The research tasks of the two geographical disciplines, carried out by different methods, are connected by the common aim to explore the natural and economic potentials of a landscape.

\section{Regional Classification of Hungary's Landscapes}

Ot the basis of principles of regional classification of landscapes, Hungary has been subdivided into landscape units which due to their related ecological landscape elements can be grouped (M. Pécsi - S. Somogyi, 1967. 1969). This classification has meant improving the earlier classifica- 
tion mainly developed by B. Bulla (1962) and S. Láng (1960). In addition, the methodological principles of the classification and demarcation of the landscapes have been developed.

A group of ecological facies has been used as a standard for landscape subdivision. These are landscape elements of nearly the same genesis and structure, where water budget, vegetation, soil cover and the type of the economic utilization are essentially homogeneous. For instance,

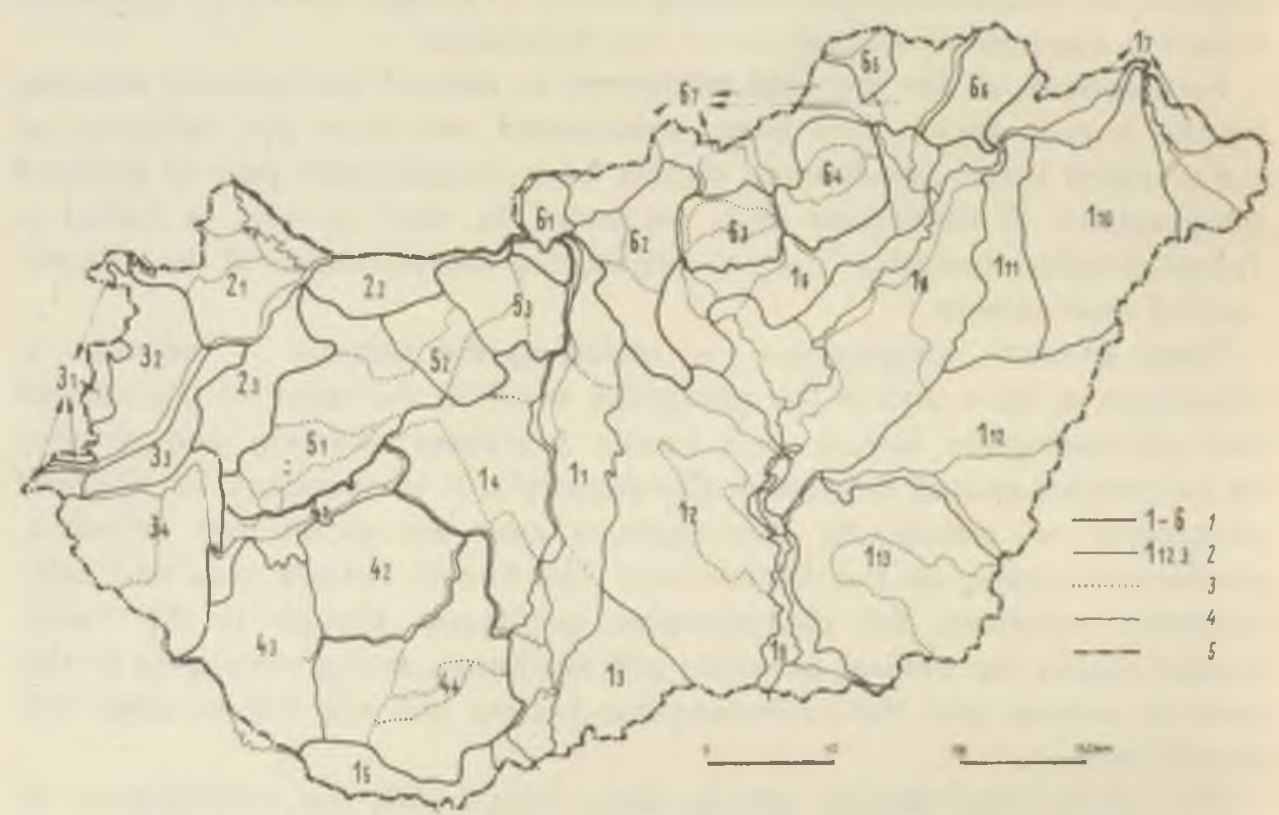

Fig. 1. Physiographic landscapes of Hungary. Classification developed by M. Pécsi and S. Somogyi. Boundaries of some landscapes traced and their names introduced with co-operation of Z. Borsy, Gy, Lovász, S. Marosi, Z. Pinczès and J. Szilárd. - 1. The Great Plain (A/föld); 1.1. The Danube Riverine; 1.2. Ridge of the Danube-Tisza Interfluve; 1.3. Bácska; 1.4. The Mezóföld; 1.5. The Dráva Riverine; 1.8. The Upper Tisza Riverine; 1.7. The Middle Tisza Riverine: 1.8. The Lower Tisza Riverine; 1.9. Alluvial fans of the Northern Great Plain; 1.10. Nyirség; 1.11. Hajdủság: 1.12. Berettyó-Körös Riverine; 1.13. The KörösMaros Interfluve; 2. The Little Plain; 2.1. Györ Basin; 2.2. Marcal Basin; 2.3. The GyörTata Terraced Plain; 3. West-Hungarian Marginal Region; 3.1. The Subalpine Region; 3.2. Sopron-Vas Plain; 3.3. Kemeneshát; 3.4. Zala Hilly Region; 4. Transdanubian Hilly Region; 4.1. Balaton Basin; 4.2. Outer Somogy; 4.3. Inner Somogy; 4.4. Mecsek Mountains and the Tolna-Baranya Hilly Region; 5. The Transdanubian Mountains; 5.1. Bakony; 5.2. Vertes and Velence Mountains; 5.3. Dunazug Mountains; 6. North Hungarian Mountains; 6.1. Mountain Region of the Danube Bend; 6.2. Cserhát Mountains; 6.3. Mátra Mountains: 6.4. Bükk Mountains; 6.5. The North Borsod Mountain Region; 6.6. Tokaj-Zemplén Mountains: 6.7. Nógrád-Borsod Basin; $1=$ boundary of macroregion; 2 = boundary of mesoregion; $3=$ boundary of subregion; 4 = boundary of microregion 
such ecological homogeneity often occurs in the regions of the Great Plain (e.g., meadow and swamp regions, regions of alkali soil, arable chernozem tablelands, etc.).

The mosaic-like network caused by the juxtaposition of related ecological facies and facio-groups forms micro-regions; and the repetitions of related micro-regions have allowed the geographers to distinguish micro-region groups (Figure 1).

The groupings of micro-regions which are similar but not identical in all characteristics have been assigned to the category of meso-regions. These meso-regions contain one type of relief (e.g., plains, mountains) but may have differences in form, structure, water regime and in the variety of forms of cultivation. (For instance, in the Great Plain there are differences between the wind-blown sands of the alluvial fans, the flood-free loess surfaces and the flood plains.)

A regional grouping of the meso-regions characterized by a homologous type of relief and by the similarity of several physical and anthropogenic landscape-forming agents, is called a macro-region.

In Hungary's territory the skeleton for the separation of macro-regions has been given by the major topographic units.

The landscape unit classification to which the Hungarian regions can be assigned is the macro-region group (mega-region) of the Carpathian Basin which is a portion of Europe's Carpatho-Balkan-Dinaric subcontinent. Within the mega-region of the Carpathian Basin. Hungary has six macroregions: the Great Plain, the Little Plain, the West-Hungarian Marginal Region, the Transdanubian Hilly Region, the Transdanubian Mountains, and the North Hungarian Mountains (Table 1).

Table 1.

\section{Macro-regions of Hungary}

1. The Great Plain

2. The Little Plain

3. West-Hungarian Marginal Region

4. Transdanubian Hilly Region

5. Transdanubian Mountains

6. North-Hungarian Mountains lintra-

Carpathian Mountains)

\begin{abstract}
Surface in sq. $\mathrm{km}$.
\end{abstract}

52,000

5,500

7,000

11,500

7,000

10,000

93,000

Percent of the
country's
surface

56

7

7,5

12,3

7,5

5

10,7

7

36 
Only the fourth and fifth macro-regions listed in Table I form a complete unit within the country's frontiers, the others, cut by political boundaries, are shared with the neighbouring countries. The obvious physiographical divergency between the macro-regions is least observable when the Little Plain and the West-Hungarian Marginal Regions are compared since the latter is just a transition to the Alps.

\section{Typology of Landscapes in Hungary}

A landscape type is composed of landscape-ecological units which are closely related to one another. The individual landscape types do not constitute large continuous areas, but they may connect types which are genetically similar (e.g., flood plain meadows, arable lands, forests of the mountain peaks and slopes, etc.). When a topological unit has been preserved in subnatural state, it is called "natural ecotop"; when it has been more or less transformed or influenced in its development by human activity, it is termed "anthropogenic or economic ecotop"; while in case of the combination of several elements of this kind, it is called landscape type. In this sense the landscape types are composed by both the natural ecotop groups (e.g., riparian and swamp forests on flood plains, alkalisoil meadows, peat bogs, etc.) and the anthropogenically influenced economic ecotop groups (arable lands and grass lands of the cultivated steppe on the higher flood plains).

The identification of the landscape types gives information about the geographical environment of the society which can be evaluated and utilized for many purposes.

Significant and fundamental information is also given by the various geological and geomorphological maps as well as by maps demonstrating different soil, vegetation and cultivation types. The landscape types are assessed and their boundaries determined by use of these maps and by the evaluation and summarizing of social activities of the various areas.

In the territory of Hungary the following main landscape types occur:

1. Continental, subcontinental forested-steppe plains, predominantly agricultural areas:

2. Subcontinental, subatlantic (de)forested hilly areas, plough lands with forest remnants;

3. Subcontinental, subatlantic forested low mountains (hilly uplands) and forested highlands (Figure 2).

In the terminology and characterization of the landscape types, however, the direction of anthropogenic activity has usually been expressed. Moreover, the fact was taken into consideration that landscape types formed on 
identical physical background, include different economic branches, and vice-versa. The aim was to discover and demonstrate spatially the actual landscape types formed by natural and social agents so that they might be best utilized in social production and regional planning.

At the same time, the landscape typology helps to determine more accurately the boundaries of the individual landscape categories.

To accomplish the classification different thematic maps were evaluated. The geomorphological map (Pécsi, 1967), the genetic soil map of Hungary (Stefancvits-Szücs, 1967), the map of Hungary's reconstructed natural vegetation (Zolyomi, 1967; Jakucs, 1970), the geological map (Szentes, F., 1967), the map of cultivation and land-utilization (Enyedi, Gy., 1967) and other special maps were utilized.* In this way the effects of landscapeforming elements were integrated. Then, with regard to the economic potentials of the landscapes, a hierarchy of natural agents was established for the individual categories. Whereas in the Great Plain regions the interest was focussed on the soil and water budget, in the Hungarian Mountains the essentials of the landscape type were best expressed by topography and vegetation. This hierarchy also has been found in the terminology of the landscape types (Figure 2).

Even though the landscape typology is based on the complex evaluation of the different fundamentals, and their hegemonial, integral and interferencial interaction, landscape typology still raises many questions. In the mountains and hilly areas the boundary between the individual types is locally indistinct, due to the broad transitional zones among them, or to the fact that the natural landscape has been transformed by human society in a number of different ways. Because of the complexity of content, scope and aims of landscape typology, the landscape types of Hungary presented in this study are considered to be just the beginning of research in this important area. More detailed investigation of the individual landscapes and the quantitative assessment of the categories are still necessary.

LOWLAND PLAINS AND THEIR TYPES

The Great Plain (Alföld)

The substratum and its genetic processes were involved in the shaping of the present landscapes and their types in the Great Plain. Rhythmical subsidence along the marginal faults of the Great Plain is a basic phenomenon which has been acting since the Tertiary period. As a result of this subsidence sandy-clayey sediment from an inland-sea accumulated

- See: National Atlas of Hungary, Carthographical Enterprise, 1967. Budapest. 
at a thickness of 1,000 to 4,000 metres, mainly during the Pliocene epoch. This sedimentary sequence, consisting of numerous formations, lies on a zonally distributed basement constituted by Paleozoic crystalline and, for the most part, Mesozoic carbonate rocks which have subsided differently in the various areas. The subsidence became relatively slower at the end of the Pliocene epoch and during the Pleistocene, but the surrounding chain of mountains rose more rapidly so that the Carpathian Basin was filled up with an alluvial fan of the Danube, Tisza and their centripetally flowing tributaries.

During the Quaternary, from several hundred to over one thousand metres of terrestrial-lacustrine sediment was deposited on the subsiding Pannonian sequence. On the wide flood plains of the rivers a thin blanket of sandy-loessy silt was settled by the floods. In the late Pleistocene epoch this fluvial and lacustrine filling was covered by eolian sands and loesses mainly on the interfluve alluvial fans out of reach of floods.

The skeleton of the Great Plain's topography is constituted by the wide flood plains of rivers and by the flood-free interfluve alluvial fans (Figure 3). The ground water regime, which is also important from the economic point of view. has developed in dependence on both the fundamental climatic characteristics of the Great Plain and on lithological and morphological conditions of the surface. The unconsolidated basin sediments contain in a vertical succession of different aquifers, inexhaustible resources of artesian water now being exploited by about 25,000 wells. Because of the low geothermal gradient the aquifers contain hot waters at depths as low as two kilometres. Moreover, in numerous places in the Great Plain considerable amounts of crude oil and natural gas have been discovered, in the Pannonian strata.

In spite of the influence of the temperate Atlantic climate, the Great Plain has a moderately continental character with several unique features which are due to the fact that it is a closed basin." Due to the climatic fundamentals the water balance of the Great Plain is negative (Figure 4), however, in spring to early summer the broad flood plains and the flat alluvial fans are characterized by abundance of water and floods. This fact has directly influenced the ecology of natural vegetation and soil formation on the flood plains and in the closed depressions of the alluvial fans. On the flood plains various azonal types of soils and plant associations have developed which have had a significant impact on the evolution of economy.

The rivers traversing the Great Plain and arriving from the neighbouring mountain chains not only control the development of the flood plains and

- For details see paper by N. Bacso in this volume. 
their ground water regime, but also transmit a considerable quantity of ground water to the alluvial fans. On these alluvial fans, as on flood-free surfaces, originally continental forest steppes and chernozem soils came into existence. The plain's natural vegetation belonged to one single floristic region - the Eupannonicum.*

At present the Great Plain, including the former natural flood plains, is almost entirely an agricultural region. On the surface of flood plains the survivors of the formerly rich marshy-aquatic plant associations have become confined to isolated spots of varying size. Thus two predominant landscape types can be distinguished: the flood plains and the culturesteppes of the alluvial fans.

The two group types can be separated from each other on the basis of their water regime and soil types. These are not only geomorphological categories, but also those of landscape types. Within the two main landscape types in the Great Plain several subtypes, topological categories can be distinguished according to the similarities and dissimilarities of soils and water budget.

\section{The Little Plain and its Landscape Types}

The natural and historical evolution of this region is related to that of the Great Plain in many respects, but it is a macro-region of smaller extent and of simpler structure. Structurally it also is a basin-like subsidence controlled by marginal faults. Thus the central part of the Little Plain is formed predominantly by different, azonal, alluvial ecological facies groups. The marginal meso-regions, on the terraces and interfluvial divides of alluvial fans are characterized topologically by subcontinental foreststeppes and forested plains.

The climate of the Little Plain (Cfbx), as compared to that of the Great Plain is less continental, its summers are somewhat cooler, in the growth season there is more precipitation, and its winters are milder. The quantity of precipitation increases towards the marginal regions; its annual average is 600 to $700 \mathrm{~mm}$. In the central, climatically drier area of the Györ Basin favourable conditions for irrigation are provided by the centripetally converging water-rich rivers, by the high ground water level, and by the great water reserves of the alluvial fans.

- See: Natural Vegetation of Hungary; in this volume. 


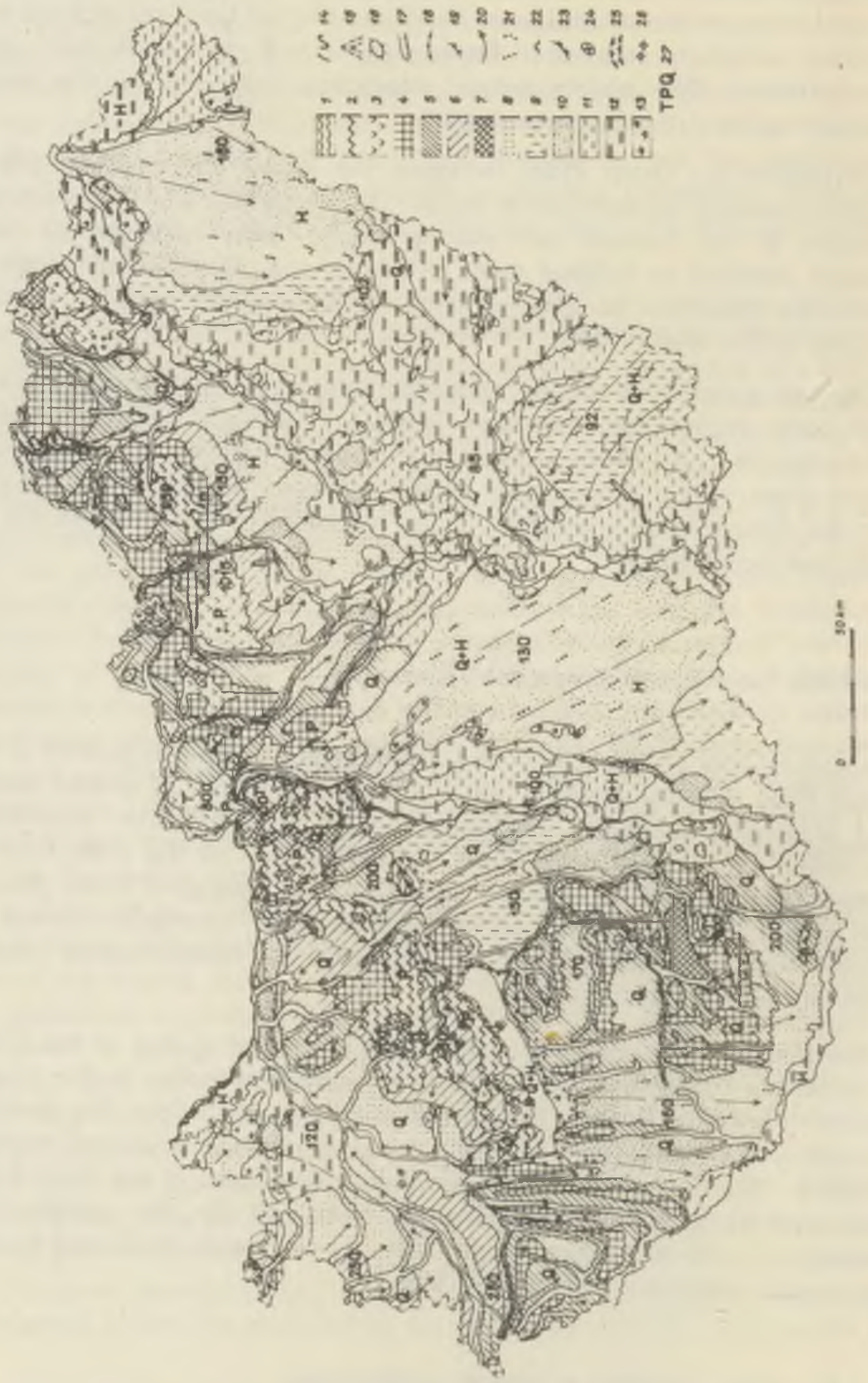




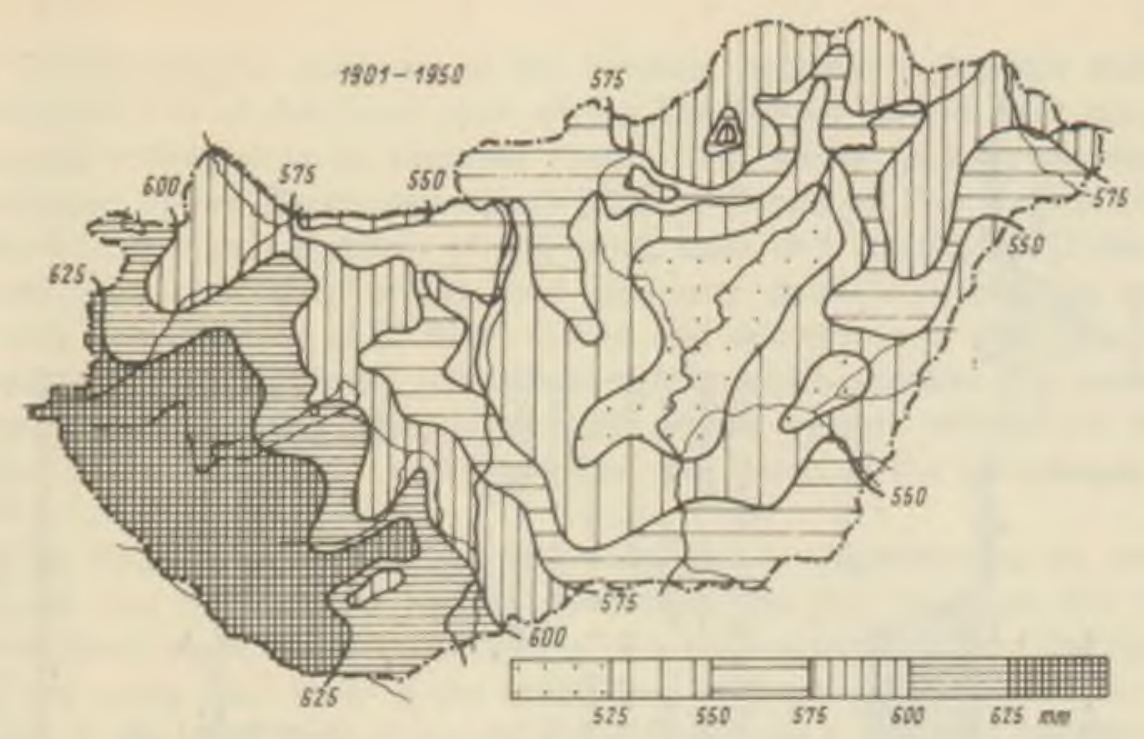

Fig. 4. Many years' average areal evaporation in Hungary, in $\mathrm{mm}$. (After J. Kakas A. Lốrincz, Mrs. Szepesi)

\section{Regulated Flood Plains}

The flood plain of the Danube Riverine is a trough-like, completely flat valley floor $200 \mathrm{~km}$ long and 20 to $30 \mathrm{~km}$ wide, extending south of Budapest to the country's frontier, and is well differentiated from its neighbourhood (Figure 1. meso-region 1.1). The average altitude a. s. I. of the flood plain is 95 to 100 metres, or 6 to 10 metres above the Danube's level at low water stage. It is bordered, especially in the west towards the Mezofold Plain, by fault-controlled and steeply underwashed bluffs. In the east it is marked off by the earlier sandy alluvial fan of the Danube - the Danube-Tisza Interfluve - especially over its southern stretch.

Fig. 3. Geomorphological Map of Hungary. $-1=$ block-faulted and folded mountains of Paleozoic structure; 2 = block-faulted and folded mountains of Mesozoic structure: 3 = young-volcanic mountains; $4=$ rolling divides; $5=$ rolling slopes, low divides; $6=$ alluvial fans in the marginal regions of the mountains, semi-plains; $7=$ small intramontane basins; $8=$ terraced alluvial fans in the marginal regions of the basins; $9=$ alluvial plains covered by loess: $10=$ alluvial plains covered by wind-blown sand; 11 = high flood plain; 12 = low flood plain; $13=$ bog, peat, muck; $14=$ oxbows, meanders; $15=$ alluvial fan on the flood plain level; $16=$ mesa-butte sculptured by erosion, terrace island; $17=$ asymmetric river valley, creek valley: $18=$ terraces: $19=$ steep bank; $20=$ alluvial fans; $21=$ dunes of wind-blown sand; $22=$ karst caves; 23 = pediment steps; 24 = mesa-butte sculptured by denudation; 25 = tectonic graben (foundered fault block); $26=$ volcanic cone in ruin; $27=$ age of landscape forms

(Tertiary, Pliocene, Quaternary forms at large) 

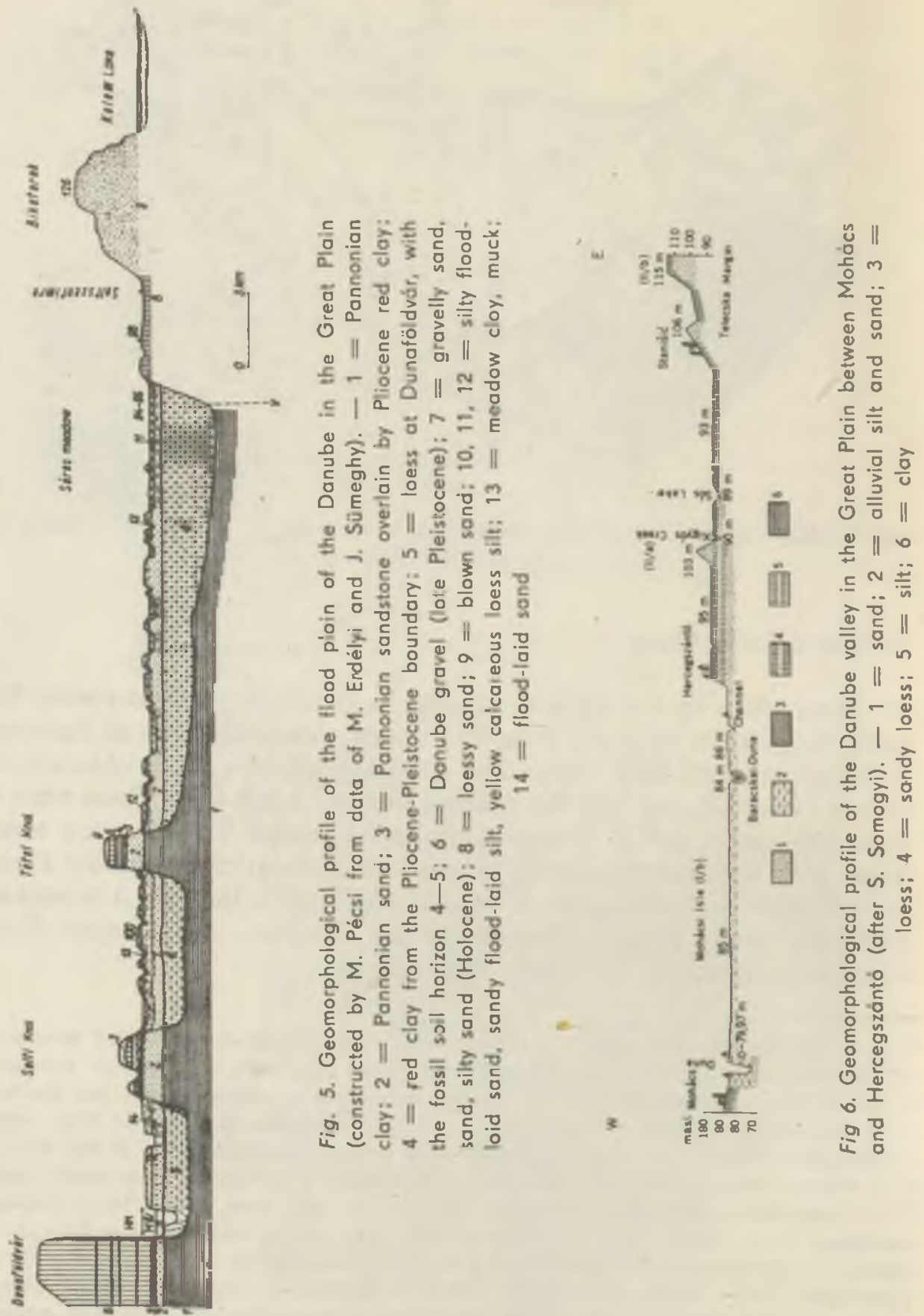

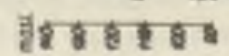


Considering the thickness of the fluviatile deposits, it appears that the northern part of the flood plain of the Danube is, for the most part, an eroded valley, while its southern stretch is a young tectonic depression subsided in the Pleistocene epoch (Figures 5 and 6). The surface of the flood plain is a few metres of silty sand, sand and loessic silt. Under this layer there are sandy gravels and clay-sand deposits, thickening southwards from a depth of 20 to 50 metres and decreasing in grain size. This sediment is vast, isolated subsurface aquifer which supplies the water for agricultural irrigation from driven wells. In dry seasons almost the whole area of the flood plain, now freed from the floods of the Danube, has to be irrigated.

The flood plain relief along the river bed is characterized by natural levees and bank-dunes. Farther away from the river bed lies the highlevel flood plain, laced by meanders and back-waters, and on the margin of the valley floor there is the broad belt of the low flood plain. The low level of the flood plain is poorly drained because it is locked between the Danube's high flood plain and the alluvial fan of the Danube-Tisza
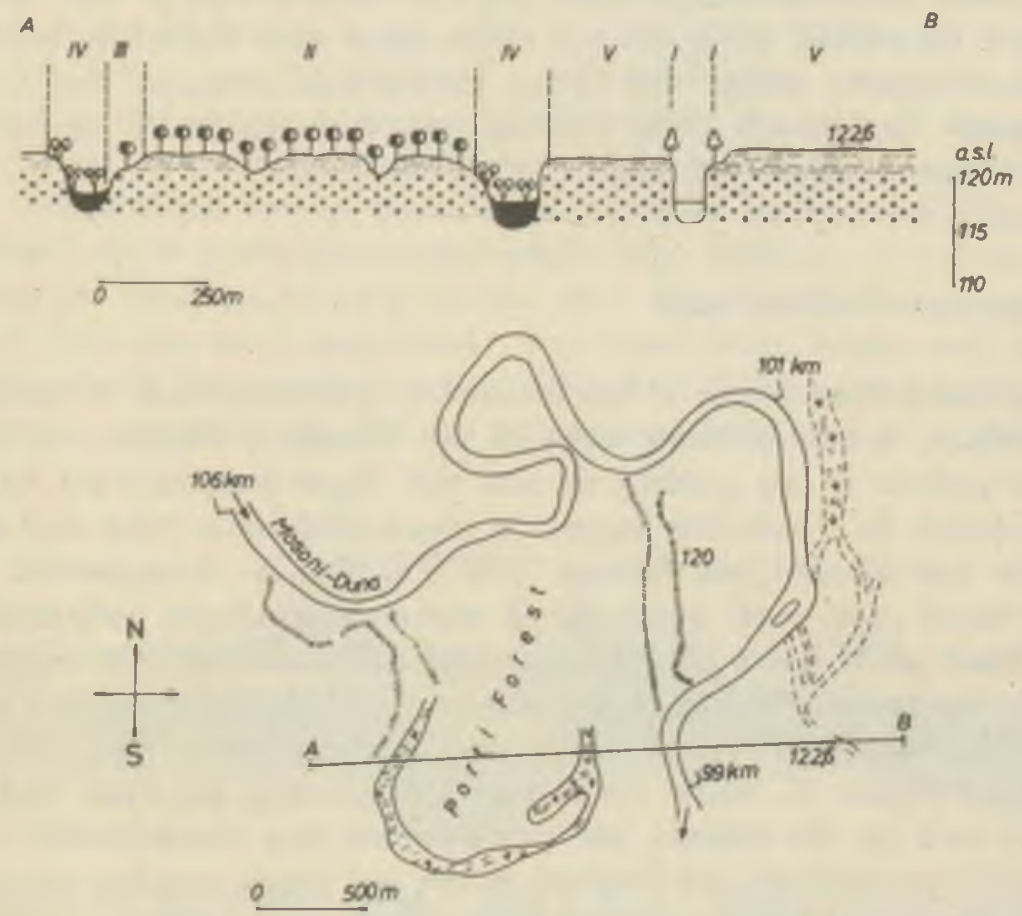

Fig. 7. Swampy oxbow lake along the Danube of Mosan (after I. Kárpáti and M. Pécsi). I = willow-poplar grove forest (Salicetum albae-fragilis); II = elm-ash-oak grove forest (Querco-Ulmetum hungaricum) - subassociation with woodruff (asperuletosum); III = elm-ash-oak grove forest - subassociation with resin and alder (alnetosum glutinosae); IV $=$ bog-forest with alder (Thelypteridi-Alnetum): $V=$ arable land 
Interfluve. On the margin of the latter in the deepest zones boggy soils have been formed. The low flood plain level which is one or two metres higher than the bog soils, is covered by vast blankets of alkali and meadow-soda soils. In the northern reaches of the Danube Valley, at the high flood plain level the soil-genesis has developed to the stage of the meadow-chernozem soil type, while in the southern stretch almost the entire width of the flood plain is mainly covered by meadow soils and it only locally shows the meadow-chernozem dynamics.

The relationship between micro-land forms and soil types is apparent. The soil types of flood plain of the Danube reflect both water budget and former natural vegetation. At present the soda soils, the swampy meadows and, in part, the deep-seated wet meadows have a significant impact on the development of the settlements, agriculture, and the economy, in general.

The Danubian Flood Plain, a characteristic and uniform meso-region of the Great Plain, is at the same time a type of flood plain landscape. Other flood plain landscape types are the flood plains of the Tisza and its larger tributaries, of which the larger ones also constitute individualized meso-regions within the Great Plain's macro-region (for instance, the Upper- and Lower Tisza Riverine, the Berettyó-Körös Region, etc.; Figure 1: meso-regions 1.6, 1.8, 1.12).

Flood plains of alluvial fans

The regulated flood plains of the Danube in the Little Plain is bordered in the south by the meandering zone of the Danube's Moson river branch. On the surface of the gravelly alluvial fan, flood-deposited silt has been accumulated. As a rule the deposit is about one meter thick and, on it a meadow soil blanket has formed. This structure is characteristic of the higher flood plain level which is an entirely agricultural landscape. The lower flood plain levels are characterized by dead channels and oxbows meandering here and there on the alluvial fan. They have wet and swampy meadows, grove and swamp forests and in many cases, their soils under cultivation (Figure 7). Inside the ramparts embanking the main bed of the Danube and on the islands, the grove forests are characteristic; willowand poplar associations are frequent in very wet areas, and the elm-ash-oak grove forests can be found on the higher flood plain levels.

The Rába and its tributaries formed a similar meadow soil flood plain alluvial fan in the Rábaköz, south of the fan of the Danube. This area has a large marshy, peaty-swampy depression of poor drainage called the Fertó-Hanság which intrudes between these two alluvial fans. Before the 
flood control and the artificial drainage of excess waters, this area was a waterland comparable to the present water surface of Lake Balaton. Now it is drained and has cultivated bog soil. With its shallow water Lake Fertō is just a modest remnant of its ancestor.

The Györ Basin (Figure 1. meso-region 2.1) which is the centre of the Little Plain, is mainly composed of the ecological types mentioned above, with which rarily flooded, slightly drier croplands characterized by alluvial and meadow chernozem soils and isolated bank-dune groups, are associated.

In the Marcal Basin, which is one of the marginal regions of the Little Plain, a flood plain occupies a rather considerable area. Here the wet, swampy meadows also have been replaced by arable lands, and only a small portion has been preserved in the form of meadows.

The flood plains of the Tisza and its tributaries also constitute mesoregions. The whole Hungarian stretch of the Tisza is accompanied by a completely flat plain.

The Upper Tisza Riverine extends down to the mouth of the Bodrog river, in front of the Tokaj Mountains, and consists of two marginal basins which subsided in the Holocene epoch. The extreme water budget of the Tisza and its tributaries over this stretch is regulated by dam systems to prevent dangerous spring and early summer floods. Along the beds of these rivers a high flood plain level extends in a broad strip which has risen from natural levees a few metres above their interfluve background (Figure 8 ). In the interfluve, in partly closed and rather large depressions, wet meadows and bogs lie. Their areas have shrunk after flood control and artificial drainage measures were undertaken. The flood plain forests and swamp vegetation mostly has disappeared as a result of the drying of habitat and putting into agricultural use. But the mosaic-like distribution of arable land,
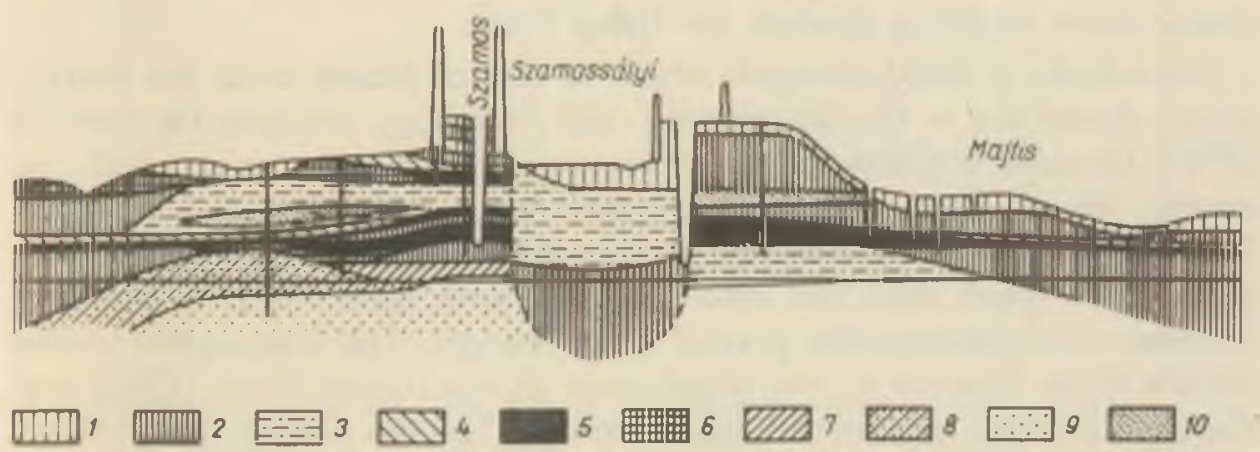

Fig. 8. Position of buried meadow soils on the Bereg-Szatmar Plain, in the Szamos-Valley (after Mrs. L. Szebẻnyi). $-1=$ alluvium: $2=$ clay; $3=$ silt; $4=$ shale-grey clay: $5=$ meadow soil, black clay: $6=$ grey clay; $7=$ blue clay; $8=$ blue silt; $9=$ finegrained blue sand, sandy silt; $10=$ yellow, fine-grained sand, sandy silt 
meadows and pastures in this region still reflects the influence of the flood plain soil types and area of higher ground water level. Vigorous development of marshes was promoted by the more rainy, local climate of the Great Plain (Dfbx), cooler than the Great Plain's average; and also by the great amounts of water flowing from the Carpathian mountains which infiltrates and is stored in the loess sandy-gravelly alluvial fan; and finally by the supposed recent subsidance of the area.

From the Tokaj Gate down to the mouth of the Körös, the flood plain jumble of the Tisza and its tributaries forms the major part of the Middle isza Riverine (Figure 1: 1.8 meso-region). It is only the so-called Nagykunság loess and the dune-patterned flood-free alluvial fan that rise one to three metres above the surrounding flood plains. The channel of the Tisza in the Upper- and Middle Tisza Riverines is quite young. Before the Holocene epoch the Tisza flowed south of the Nyirség along the Ér-BerettyóKörös towards the present Lower Tisza Valley. Its reaches between Tokaj and Szolnok developed because due to the postglacial marginal subsidences of the territory of the Upper Tisza Riverine, the Tisza took up the waters of the Bodrog, Sajó and Hernád, and with its increased size, it cut off the flat alluvial fan of the Sajo-Eger-Tarna tributaries in the Nagykunság, setting it apart from the piedmont sector (Figure 9). With its incisions and meanderings in seemingly pre-tectonized zone, it built up a broad flood plain. The tributaries developed their flood plains at the same level and in the same way (e. g., the flood plain of the Zagyva-Tarna).

Prior to flood control, the alkali soil grassland ("puszta") of the Hortobágy also belonged to the present silt-covered flood plain of the Tisza. During floods, a portion of the Tisza's water flowed through the Hortobágy towards the Berettyo and the Körös rivers. Before the appearance of the Tisza in this stretch the Sajo and Hernád periodically followed the same course while travelling through the Great Plain.

The oxbows of dead channels which in several places cross the loessic, sandy alluvial fan in the Nagykunság and Hortobágy, preserve the memory of the intricate labirynth of water courses. The present rivers and the natural levees along the dead channels and cut-off meaders are surrounded on all sides by bowl-like depressions. These depressions have been dotted with alkali soils and alkali meadow soils as a result of the poor drainage and infavourable ground water budget. The flood plain of the Middle Tisza Riverine is the driest area of the Great Plain (Cfbx) and therefore summer irrigation is indispensable. For this reason a significant irrigation canal network has recently been developed over the Hortobágy area and along the Tisza.

The less productive, dry alkali patches have been and are still characterized by meadows and pastures, while tine meadow allivial soils and 


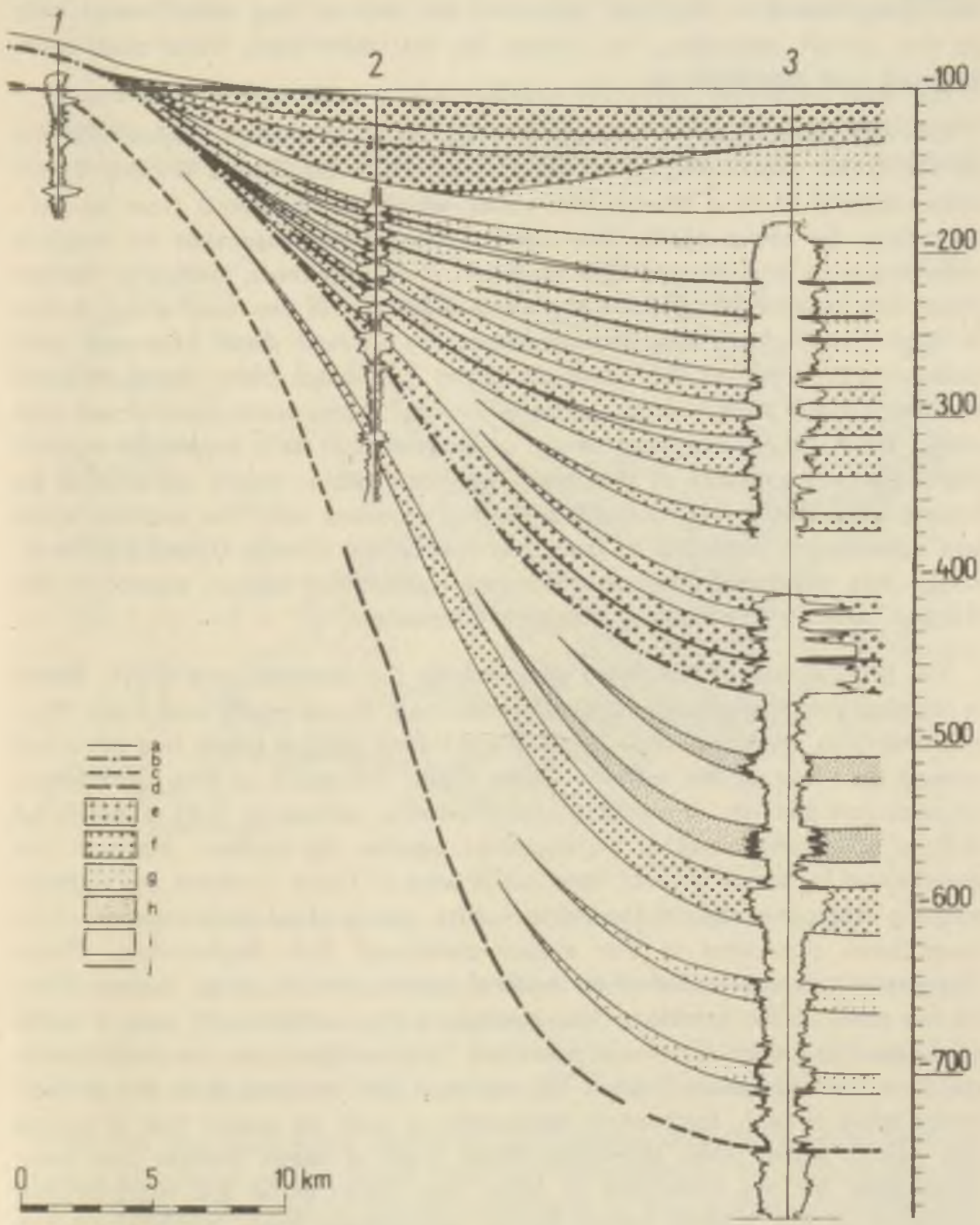

Fig. 9. Geological profile from the Middle Tisza Riverine (after d. Urbancsek). $-1=$ Emöd; 2 = Mezöcsát; 3 = Tiszacsege; $a=$ surface; $b=$ boundary of Pleistocene sediments; $c=$ boundary of the Pliocene sediments; $d=$ supposed boundary of the Pliocene sediments; $e=$ gravelly sand, sandy gravel; $f=$ coarse-grained sand; $g=$ medium- and fine-grained sand; $h=$ silty sand; $i=$ silt, clay; $j=$ interbedded clay in aquifer 
meadow soils have became arable lands. The process of marsh formation was insignificant in the flood plains of this region. Bog soils formed only in the cut-off meanders, but these, for the most part, have also been drained and ploughed up.

The flat flood plain in the Lower Tisza Riverine is the deepest surface of the Great Plain lying at an altitude of 78 to 80 metres (Figure 1: 1.8 meso-region). It is a trough-like valley which is separated from its surroundings by sharp bluffs. The name Tisza-graben expresses its tectonic subsidence in a supposed N-S direction. In its southern stretch a narrow flood-free terrace strip follows the western margin of the flood plain. It has a high flood plain level, honeycombed by incised dead channels and oxbows which are at the same time, the low flood plain levels. Around the settlements of this area separate circular dams were constructed and along the rivers, strong longitudinal ones were built as a protection against the long-lasting floods of the river. The flood plain, mostly constituted by loessic silts, is covered by flood-deposited meadow soil. The sodified spots are subordinate, and due to its rather favourable climate ( $\mathrm{Cfax}$ ) this landscape has developed into an advanced agricultural region, except in the Szeged area, which has an industrial character.

The alluvial fan of the flood plain along the Berettyó and Körös Rivers is wedged into the alluvial fans of the Nyirség. Nagykunsag and Tisza-Maros Interfluve, this landscape is a still subsiding surface which has attracted almost all rivers of the eastern Great Plain. The basis of this Quaternary alluvial fan consists of various-sized fluviatile sediments with a depth of 200 to 300 metres and is an excellent aquifer. Its eastern margins are constituted by sandy alluvial fans, while west of these - where the slightlysloping Holocene alluvial fan ends - silts, sandy clays and meadow clays have been deposited in the mosaic-patterned flat depressions. These depressions are surrounded by natural levees one to three metres high. In the zone of the bankless river meanders wind whimsically over a width of a few kilometres. On these so-called "river-ridges" are the settlements, gardens and vineyards (Figure 10), while in the inclosed flats the ground water table is high, fluctuating seasonally to such an extent that in spring the excess water often stagnates there. Such a water budget has been favourable for the formation of large bog soils, while the impermeable sediment of the slightly higher banks surrounding these depressions has favoured sodification. The alkali meadow soil used to cover large areas, but a significant portion of them were reclaimed agriculturally. Since drainage the cultivated bog soils have shrunk considerably, while the meadow soils have become meadow-chernozems. The present situation of the arable lands, meadows, pastures and marshy forests is, for the most 
part, constituted by the past and present physical and anthropogenic characteristics of the landscape.

At present all flood plains of the Great Plain are regulated, and are a landscape type composed of related ecological facies groups transformed by anthropogenic actions. These groups can be most simply characterized

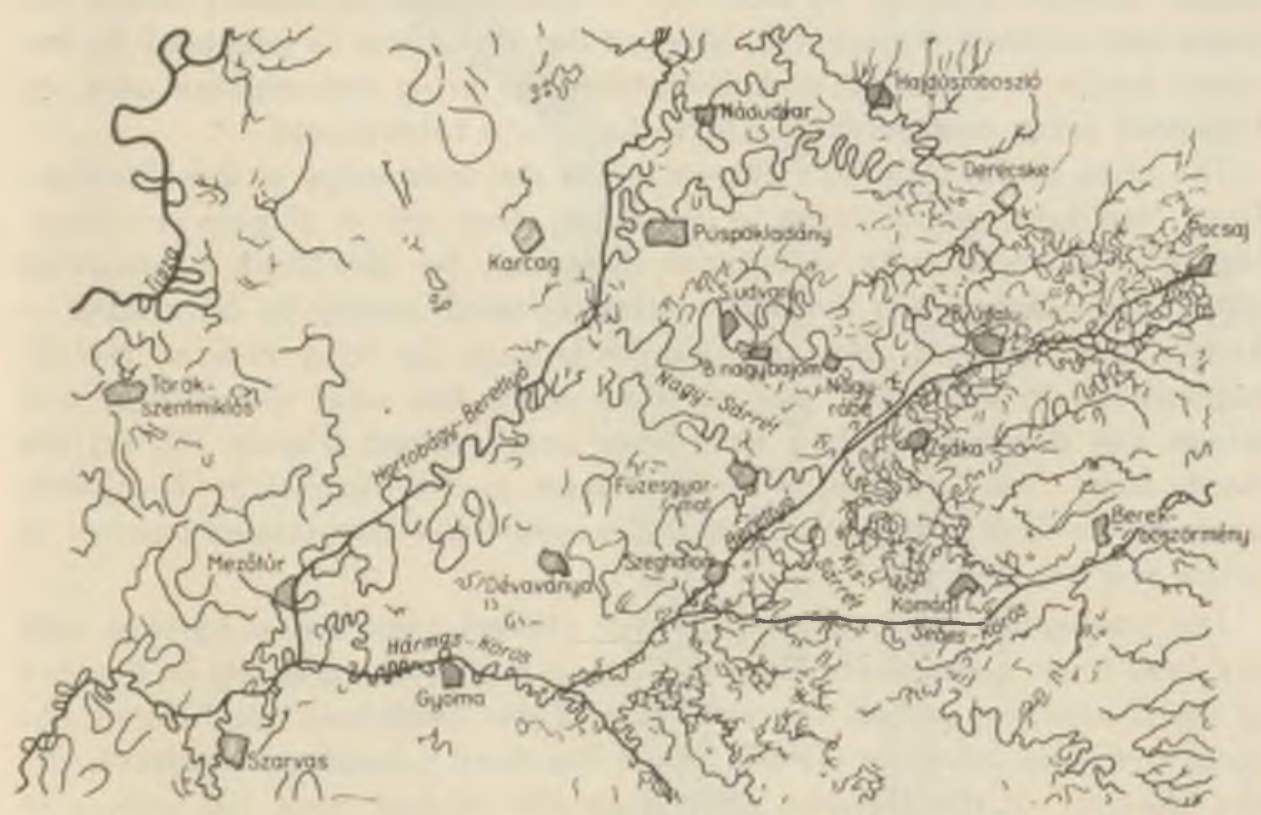

Fig. 10. Cut-off river beds of the Koros Riverine (after A. Popp).

by the water budget and soil types which best reflect the anthropogenic effect (Figure 2). In this way the improvement of the soils has been accelerated by man's intervention and the evolution of soil types has had to obey the laws imposed by the new ground water conditions.

Thus the regulated flood plains of the Danube and the Tisza as well as of their tributaries in the Great Plain are characterized by ecological types 1-7 of Figure 2. Only in the assemblages of the individual topological types can be found local differences which are due to the different development of environment and agricultural production. 
Continental Culture-Steppes of the Alluvial Fans

Sandy Types of the Alluvial Fans

The largest alluvial fan in the Great Plain is that of the Danube. Its northern extremity is the Pest Plain, on which the lower terraces have been covered mostly by sand (levels II/a, II b, III), while the sandy gravel of the higher terraces (No. IV, V) crop out in several places directly below the forest soil sections (Figure 11). Most of the Pest Plain is occupied by the urban jungle of Budapest and the settlements of its metropolitan area, by industrial areas and gardens; arable lands are subordinate.

The trunk of the Danube's alluvial fan is the sand ridge of the DanubeTisza Interfluve, which forms a separate meso-region (Figure 1: mesoregion 1.2). Three main ecological types can be identified in recurring strips and patches: (a) landscape types covered mainly by blownsand humic sand blnakets, blownsand dune-groups; (b) long N-S or NW-SE depressions in which the ground water table lies near the surface and where wet meadows or bog soils have been formed (Figure 12), (c) the sandy loess fields covered with chernozem in the Nagykörös-Kecskemét area. In the third category and in the meadow soil depressions patches of alkali soil are frequent.

The ecological characteristics of the alluvial fans are congruent with the land forms brought about by the eolian processes occurring at the end of the Quaternary period. The formation of the windblown sand dunes has continued even in recent historic times. The deep subsurface sediments are the deposits of the Danube, they gradually thicken from 100 meters in Budapest to 800 meters towards Szeged. Among the predominantly sandy strata subordinate eolian and lacustrine layers are imbedded. Among them in several levels coarser (gravelly) sand layers can be found which are rich aquifers.

Social activity has transformed the landscape considerably. The former sand plains, loess steppe meadows, and oak forests and groves have been transformed into cultivated meadows. The windblown sand dunes clad with poplar and juniper vegetation have been planted with forests or orchards and vineyards. The wet meadows, meadow swamps lying among the dunes have been replaced by arable lands and orchards. Due to the favourable climatic conditions the Danube-Tisza Interfluve is famous for its fruit production.

The Nyirseg is another of the alluvial fans of the Great Plain. It is the Pleistocene alluvial fan of the Tisza and its northern Great Plain tributaries. Its surface is also mainly covered by blownsand. Many of its characteristics are similar to those of the Danube's Great Plain alluvial fan, and it 


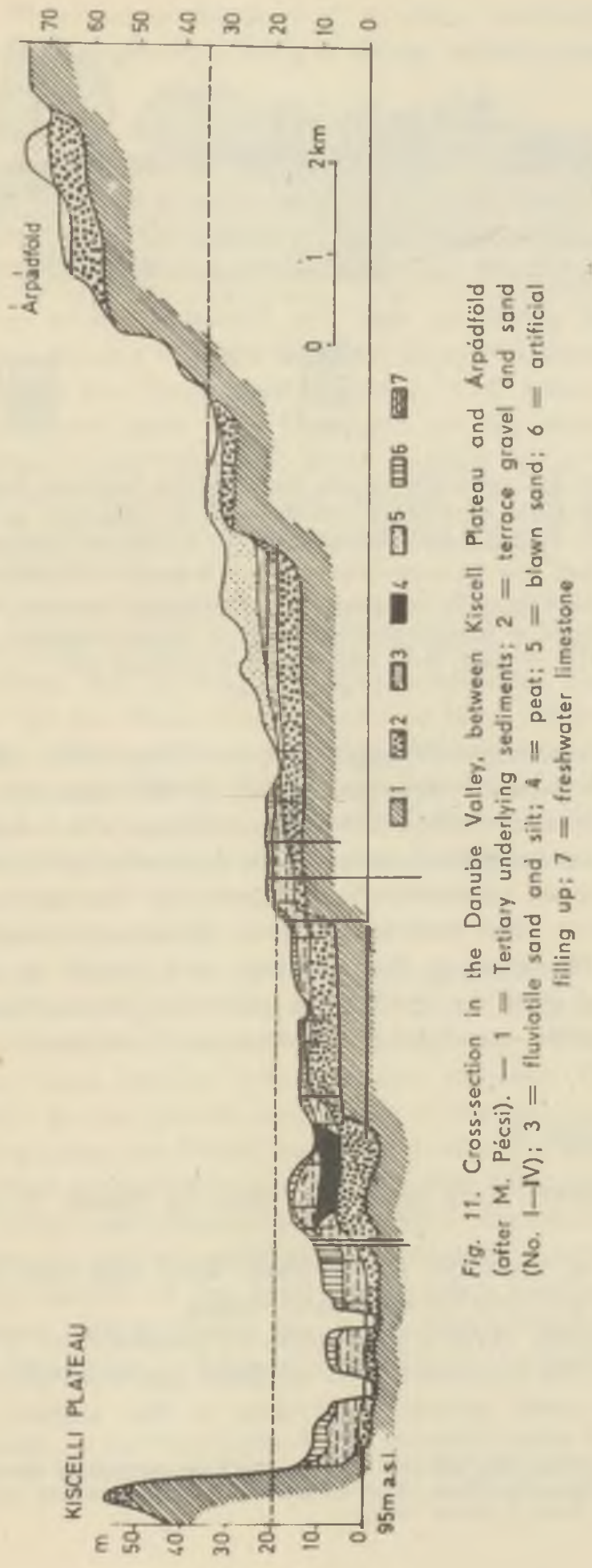




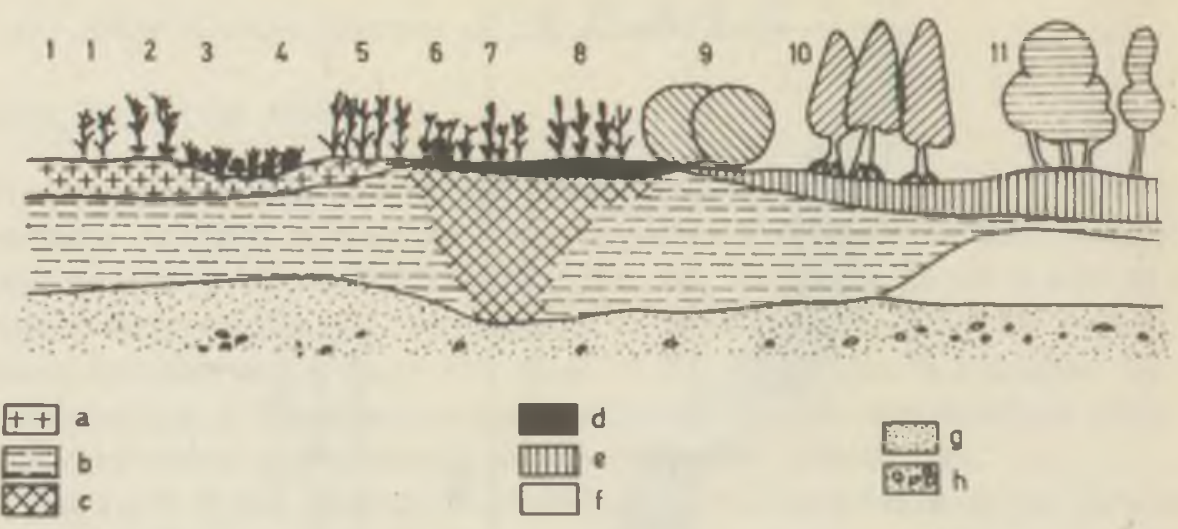

Fig. 12. Vegetation and soil profile of the Danube-Tisza Interfluve. Relation between the boggy meadow, its forest associations and the soils of turjanvidék of Ocsa-Dabas (after M. Komlódi). - 1 = Juncetum subnodulosi; 2 = Caricetum acutiformis-ripariae; $3=$ Carici-Menyanthetum: $4=$ Coricetum elatae: $5=$ Cladietum: $6=$ Schoenetum nigricantis : $7=$ Molinietum coerulea with Schoenus: $8=$ Molinietum coerulea; 9 = CalamagrostiSalicetum cinereae; $10=$ Dryopteridi-Alnetum; 11 = Querco-Ulmetum; 0 = meadow soil: $\mathrm{b}=$ gley-horizont $; \mathrm{c}=$ peat $\mathrm{d}=$ mull soil; $\mathrm{e}=$ lenwood soil; $f=$ loess; $\mathrm{g}=$ sand

$$
h=\text { gravel }
$$

also forms a separate meso-region of the Great Plain (Figure 1: mesoregion 1.10). The dune ranges are mainly of $\mathrm{N}-\mathrm{S}$ direction. Between them there are longitudinal valleys with poor drainage which have swamps and stretches characterized by meadow soils and alluvial sand.* These areas had to be drained by artificial canal network. The northern part of the Nyirség sand has been covered by brown forest soil, directly underlain by loessic sand. However, in the southern part rough or poorly humified windblown sand gives the site for the cultivation. Vast arable lands, patchlike apple-orchards, meadows and forests are characteristic of the Nyirség.

\section{Cultivated Loess Lowlands}

Chernozem-covered loess fields can also be found. It joins the sandy alluvial fan.

In the zone of transition sand, loessic sand and loess spots are intercalated with chernozem-covered sand dunes.

In the Hajduság cereals production is predominant (Figure 1: mesoregion 1.11). In the basement of its southern part the Pannonian sediments in this region come conspicuously close to the surface, unlike in the

* In the dune ranges the ground water is near the surface in the Nyirsè as well as in the Danube-Tisza Interfluve, and follows its configuration in a slightly flattening pattern (A. Rónai, 1961; Z. Borsy, 1961). 
adjacent Great Plain areas. Because of its more northerly position, the Hajduság has a cooler climate ( $\mathrm{Cfbx}$ ). It slopes westerly towards the Hortobágy Plain.

The Bácska (Figure 1: meso-region 1.3), which is famous for its wheat, maize and fruit production, is one of the most excellent croplands of Hungary. The sandy loess plateau faces the flood plain of the Danube valley with a bluff. This valley formed as late as the end of the Pleistocene and the Bácska Plateau was separated from the Mezöföld at that time.

The alluvial fan of the Mezöföld was built up during the Pleistocene epoch by the rivers flowing from the Transdanubian Mountains towards the Great Plain. During the Quaternary period a thick loess cover and in some places windblown sand were deposited on the older river gravels and interfluve ridges of the Mezöfold. These deposits lie on the Pannonian strata roughly at the present level of the Danube. With its gradual shifting to the west, the Danube formed steep escarpment 20 to 50 metres high on the edge of the Mezöföld.*

The Mezöföld is a low elevated loess plateau covered by typical chernozem, the predominantly smooth, level surface of which is locally interrupted by wide river valleys and by hilly or rolling landscapes dissected by dry derasion valleys. On the slopes soil erosion has been become accelerated due to cultivation. Originally a forest steppe landscape, this territory is now under intensive agricultural cultivation producing such crops as wheat and maize. Because of its position between Budapest, Lake Velence and Lake Balaton and the Danube, the former exclusively agricultural function is rapidly being replaced by a variety of economic branches including industry, recreation and services.

The Kärös-Maros Interfluve is the most homogeneous of all the alluvial fans of the Great Plain (Figure 1: meso-region 1.13). On its surface meadow chernozem and "lowland chernozem" are predominant. These soils have become locally in large patches salty in deeper horizons. The silty, loamy soils are underlain by the gravels and sands of the alluvial fan. With its Holocene river branches the Maros has shifted over the whole area, and here too the natural levees built up along the river channels have closed around several alkali soil depressions. In these depressions seasonally waterlogged patces as well as meadows and pastures have been preserved. The overwhelming majority of the landscape is table land and it provides an excellent soil for raising wheat, rice, maize and various thermophilous spice cultures. Climatically, in terms of the number of sunshine hours and

* Along the Danube, in the high banks of the Mezôföld locally almost the entire Quaternary sedimentary formation can be seen, with 6 to 10 fossil soil levels and erosive discordances between the loess and sand layers (L. Adám-S. Marosi-J. Szilárd, 1959). 
the total heat-flux $\left(<3300{ }^{\circ} \mathrm{C}\right)$ of the growth season, this is the richest (Cfax) landscape of the Great Plain.

The alluvial fans of the northern Great Plain form a transition zone between the Great Plain and the Intra-Carpathian Mountains. It is composed of micro-regions which have several similar characteristics, but differ from one another like the components of a mosaic. It is repeatedly dissected by narrow valleys along the Tisza tributaries. Its surface is homogeneous in thezone bordering on the flood plains of Tisza and it can be characterized by slightly sloping, flood-free interfluve ridges. It forms foothills in the foreland near the mountains, which are divided by the tributaries into more dissected, round interfluvial ridges. These higher levels are covered by brown forest soil and chernozem-brown forest soil. The gentle slopes of the alluvial fans and foothills are covered by solifluctional-deluvial, alluvial tracts of slope in varying thicknesses. The reworked humus and mineral substance of the Pleistocene fossil soils were mingled into these soils. Elsewhere at small depths under the surface, fossil soil can also be found. The south-facing slopes, which are of favourable micro- and meso-climate $(\mathrm{Cfbx})$, are excellent cropland for the vineyards and fruit orchards. The famous vine districts at the foot of the Mátra. Bükk and Tokaj mountains belong mostly to the foreland of the Intra-Carpathian mountains.

The lower plain of the alluvial fan range is grain-producing, and in the part lying closer to the flood plain level, where the ground water table is near the surface, the conditions for the production of the hoed riants are favourable.

\section{Subcontinental-Subatlantic Deforested Marginal Plains}

The Marginal Landscapes of the Little Plain

In the Marcal Basin (Figure 1: meso-region 2.2) the intra-valley ridges running down from the Bakony Mountains, are covered by alluvial fan gravels and sands. Due to the more humid climate in this area the greybrown podzolic soil dominates. The intra-valley ridges are more disintegrated in areas closer to the Bakony Mountains. The monadnocks (Somlo Mountain, Ság Mountain, etc.) which consist of Pannonian strata and are basalt-capped, are characteristic elements of this landscape. The pebble and loam soils of their slopes of cone-frust type support famous vineyards. They are monadnocks since they rise 100 to 150 metres above their base thus showing the position of the Pannonian surface as it lay at the end of the Pliocene. 
The Gyōr-Tata Terraced Plain occupies the older alluvial fan terraces of the Danube. An alluvial fan slope joins this landscape in the south, at the foothills of the Bakony-Vertes Mountains. The surface of the latter is locally divided into landscapes of hilly character by the dense network of derasion valleys and facing the Danube. The climate of this meso-region of the Little Plain is the driest. The overwhelming majority of its surface is covered by chernozem soils, except for minor brown forest soil patches.

Marginal Alluvial Fans of SW Little Plain

South of the Little Plain a transitional landscape extends southwestwards along the banks of the Rába, as a part of the West-Hungarian Marginal Region. Morphologically it is a lowland, but its climate (Cfbx"), water budget, phyto- and pedogeographical conditions are influenced by the neighbouring Alps. Due to this fact, it was macro-regionally separated from the Little Plain. Its landscape ecotypes are similar to those of the edge of the Great Plain. Geomorphologically, it is a vast alluvial fan plain the gravelly surface of which is dissected by flat intervalley ridges of the rivers running down from the Alps. This gravelly surface was originally covered by subatlantic-subcontinental forest. The landscape nowadays is a culture steppe. Its surface is locally covered with a cemented gravel blanket without any soil and thus a barren and tree-less steppe has developed.

The Sopron-Vas Plain. During the Pleistocene epoch the Rába and its tributaries which rush down from the foothills of the eastern Sub-Alps towards the Little Plain built up a huge gravelly alluvial fan. The surface of the level Sopron-Vas alluvial fan was slowly dissected by river valleys, due to the subsidence of the central Little Plain which can still be observed. During the last glaciation "brown earth", silty-loamy deposit have been formed on the surface of the alluvial fan, on which fertile forest soils also have developed.

The gravel-covered long whaleback east of the middle Rába valley parallel to the river is the Kemeneshát. This is the oldest remnant of the subalpine gravel sheet, a butte of the alluvial fan. Its grey-brown podzolic soil is utilized as narrow strips of arable land and as vast oak and mixed forests.

The Rába Valley has been cut along an early fault line which recently was rejuvenated in a SW-NE direction, between the Vas and Kemeneshát alluvial fan plains. It is accompanied by well-preserved terraces, Its present flood plain is several kilometers in width and belongs to the Little Plain as far as Körmend. The valley becomes wider to the north and merges 
with the flood plain of the Rábaköz. The former alder-poplar-willow swamp forests occur as isolated patches. At present, the Rába valley contains wet meadows, while the high flood plains serve as arable lands.

Such marginal transitional landscape types of subcontinental character can be found not only south of the Little Plain, but along the dividing line between the Great Plain and the Hungarian Mountains, as well. They are characterized, among other factors, by a ground water table lying deeper than average and by the transformation of the former rorest soils into chernozem as a result of the dynamic agricultural cultivation. In general, the termination of the marginal alluvial fans coincides with this marginal lowland zone, therefore the surface is more dissected and richer in microforms than in the interior part of the Great Plain. Agricultural expansion in this region seems to be unrivalled.

From a comparison of the maps shown in Figure 1 and Figure 2 it is obvious that the two differ from each other in some respects. On the basis of their ecological facies some meso-regions belonging morphologically to the West-Hungarian Marginal Region (3.2) or to the Transdanubian Hilly Region have been ranked as landscape types, among the lowland types sather than among the hilly countries. Their predominant, society-controlled characteristics bring them closer to the lowland types.

It is obvious from the natural resources of the Little and Great Plains, that their most important asset is their fertile soil. This, due to the water budget depending on the lithologic-geomorphic-climatic conditions, can be differently utilized for agriculture. Besides soil utilization, the hydrocarbon resources, the thermal hot-waters are significant.

HILLY LANDSCAPES AND THEIR TYPES

The Fectures of the Hilly Lanscape Types

The predominant characteristics of the Hungarian hilly regions are the strong linear-erosive dismembering on the substratum of loose material, and the erosion-derasion processes which formed the trough-shaped dry valleys dissecting the hilly countries. The valleys and the intravalley ridges and their slopes are developed not only of fluviatile-erosion character, because they also have been formed by the erosion of the surface. During the Pleistocene glacial ages the increased cryogenic solifluction and mass movement processes, on the slopes the so-called derasion process displayed significant activity on the surface of the present hilly countries. 
During the Pleistocene, in the morphogenesis of the hilly countries, linear erosion was predominant in the mild-humid climatic periods, while during the cold, dry, glacial periods the eolian sedimentation and the cryoplanation were dominant.

The cool humid stages of the glacials were the most favourable conditions for downslope mass movements, for the deposition of solifluctional stratified sediments, for the development of derasion valleys and forms as well as for the cryogenic phenomena.

During the Pleistocene-Holocene periods when the overall rising tendency of the Alp-Carpathian Mountain System occured, the hilly countries of Hungary endured considerable synorogene tectonic effects. As a consequence, the Upper Tertiary geosyncline of the Carpathian Basin yradually emerged from the sea, especially in the western and southern parts of Transdanubia.

The elevated hilly countries were dissected by a dense and deep valley network. It the different stages of the Quaternary period, the accumulation continued in the relatively subsiding depressions of the hilly countries under consideration.

The composition of the hilly regions is rather varied. The surface, and locally the deeper strata themselves generally are composed primarily of Tertiary loose sediments, Oligocene-Miocene sand and clay, PliocenePannonian sand and clay, and subordinately of Quaternary fluviatile sand and gravel, eolian loess, slope-loess, loess-like deluvial slope deposit.

Directly in the mountains' margins the relief forms can be characterized by the foothill surfaces consisting of solid rocks pedimented down to the level of the hills, by the "glacis" forms developed on the loose sediments. or by their form-facies brought about by dissection into intra-valley ridges. These formations are covered in many places by correlative sediments removed from the mountains.

The geological structure is mosaic-like which is strongly homogenized by the other factors determining the landscape type, thus depriving the geographer of any criteria for classification. The relative altitude and the degree of dissection by valleys, however, can be useful standard. In such a way it is possible to classify the hilly countries according to the criteria of light-, medium and strong dissection depending on whether the relief energy per square kilometer is below 50 meters or higher than 100 meters. This is expressed in Figure 2, where the colour signes correspond to three dissection degrees. Obviously, the degree of dissection is determined by the structural-tectonic conditions on the one hand, and by the climaticgeomorphic fundamentals, on the other.

Another factor which can be used is the climate. The hilly regıons situated south, and south-east of the axis of the Hungarian Mountains can 
generally be characterized by a subcontinental, dry climate. But this dividing line is inconclusive. Northwest of this line subcontinental climate exists while south-east of it sub-Atlantic - sub-Mediterranean climates can be found in the hilly countries. The climate types here depend on the direction of the slopes and the altitude. West of Lake Balaton the hilly countries are of sub-Atlantic character and northeast of the Visegrad Gorge of the Danube all regions have subcontinental and continental climate.

The climate of these areas is reflected in the natural vegetation and its continuous remains. Although on the surfaces of the moderately dissected lower hilly countries only the remnants of the original natural vegetation can be found.

The zonal Turkey-oak and oak forest remnants of the hilly landscapes reflect the subcontinental-continental climatic type. The sub-Atlantic types can also be well separated using the remnants of mixed forests (oakbeech-pine forests in the same region), though this type is more wooded than the former one.

Another tangible expression of the humidity-aridity of the climate is provided by the equation of the water budget. The dividing line of the sub-Atlantic - subcontinental types oscillates just about the zero value.*

In the classification and termination of single hilly landscape types, it is the genetic soil types and sub-types that play the predominant role among the factors determining the landscape type. Thus the complex local effect of the factors determining the ecological unity of the living world occurs most directly in the soil formations. The hilly regions are situated higher than the base level, therefore the zonality-disturbing role of the ground water does not prevail. The zonal soil types can be identified precisely in the hilly countries, in the most regular arrangement. Many types of soils occur in the Hungarian hilly regions from the chernozem (related to typical steppe conditions), to the grey brown podzolic soils.

\section{Independent Hilly Landscapes in Hungary}

In Hungary, according to the relief- and landscape characteristics, two regions can be referred to the hilly landscape category: the West Hungarian Marginal Region and the Transdanubian Hilly Region.

The subdivision of the two hilly landscapes into separate macro-regions is justified because of the climatic differences which determine their bio-

* Here the minus sign expresses the water loss, the plus sign the excess water in absolute values, within each particular landscape type. In addition to the values of the water balance, the mean temperatures of January and July also are shown. 
sphere. In the western landscapes of the country the Alps have been responsible for the formation of a climate of a mild-humid character and for the development of the typically sub-Atlantic character of vegetation and soil conditions. South of Lake Balaton, the moderately moist, milder continental climate has formed the characteristics of the sub-Mediterranean vegetation with the adequate soil types.

The hilly countries of the West-Hungarian Marginal Region are made up by the hilly landscapes of Upper-Vas and Zala counties (Figure 1: mesoregions 3.1 and 3.3 and 3.4). The hills of Somogy-Tolna and Baranya Counties belong to the Transdanubian Hilly Region (Figure 1: meso-regions $4.2,4.3$ and 4.4 ).

\section{Foothills and Intermountain Hills}

Hilly landscapes also occur within the macro-regions of the Hungarian Mountains. On the one hand, they occur in the foreland and on the margins of the mountains, and on the other hand in the tectonic basins within the mountains. The extent of the hilly landscapes in the mountain foreland and the width of the transition zone between subsiding plains and elevating mountains depend on the rock types of the mountains and hills, and on the degree of the tectonic movements and of the exogeneous processes shaping the hilly landscapes.

The marginal hilly landscapes, in the foreland of the Transdanubian Mountains in general have a temperately continental climate, and surround the horsts of the Mesozoic block mountains of Eastern-Alpine type.

The hilly landscapes of the North Hungarian Mountains partly surround the Intra-Carpathian volcanic range, partly surround the Paleozoic and Mesozoic mountain blocks. In the northern foreland of the Intra-Carpathian range a series of hilly basins, filled up by Tertiary marine clayey-sandy sediments and covered by loessic-loamy slope deposits, extends to the frontier of Hungary and beyond it well into the Slovak Mountains. With the uplifting of the mountain members, these basins also elevated and as a consequence have been incised profoundly by watercourses. Consequently they have developed into hilly countries of marked relative relief. The common peculiarity of the basin-hilly region which lies north of the North Hungarian Mountains, is dryness and frequent atmospheric inversions due to the inter-mountain position.

A special type of the basin-hilly landscape is the considerably dissected units of the minor basins lying inside the mountains. These basins generally are filled by sediments which are less dense than the rocks constituting the mountain, so the erosion-derasion processes have devastated them. These areas possess dry climate as compared to their environs, and owing 
to their isolation, they have frequent atmospheric inversion, and on extreme continental climate. They usually are the scene of agricultural or industrial activities conducted by inhabitants of minor settlements.

All the piedmont, marginal and intramountain hills are just parts or subunits of the mountainous meso-regions. Only basin ranges which lie north the range of the Northern Mountains, along the Ipoly and Sajo rivers and are of mainly hilly country character, are considered to be meso-region (Figure 1: meso-region 6.7). Smaller hilly inter-mountain basins occur in almost all mountainous landscapes.

\section{Transdanubian Hilly Region}

In the internal area of the Pannonian Basin lies the macro-region of Hungary which consists of independent hilly countries and is closed between Lake Balaton and the flood plains of the Sio-Danube-Drave rivers. The close juxtaposition of heterogeneous ecological facies is characteristic of this entire area.

The climate of the area is characterized by the duality of the temperate sub-Atlantic and sub-Mediterranean features $\left\langle\mathrm{Cfbx}\left(\mathrm{x}^{\prime \prime}\right)\right\rangle$. The precipitation of the region as a whole surpass 600 millimetres, and in the region between Lake Balaton and the Drave, it reaches an average of 750 millimetres a year. Due to the high evaporation values $(600-625 \mathrm{~mm})$ the water budget of the area below 700 millimetres precipitation is deficient. The average temperature of the region is $10^{\circ} \mathrm{C}$, except in the area of the Mecsek Mountains. The southeastern landscapes also are rich in sunshine. The second precipitation maximum occurs in autumn, with decreasing intensity to the east.

The waters of the area run, in the south to the Drave, in the north to Lake Balaton, and in the east toth e Sio and Danube. The sandy, clayey Pannonian layers of the dissected hills are neither characterized by a continuous ground-water table.

The landscapes, which are homogeneous in their structural-morphological peculiarities and in their climatic-water budget fundamentals, can be typified acording to their plant and soil geographical conditions. Main landscape type groups are: the Mecsek and Villany Mountains; the hilly country of Somogy; the hilly country of Tolna; and the hills of Baranya.

The Hilly Region of Baranya, the Mecsek and Villány Mountains

The Villány Mountains which is surrounded by typical hilly landscapes is a series of simple horsts with an imbricated structure, while the Mecseh Mountains are stepped block-mountain range of a more complex structure 


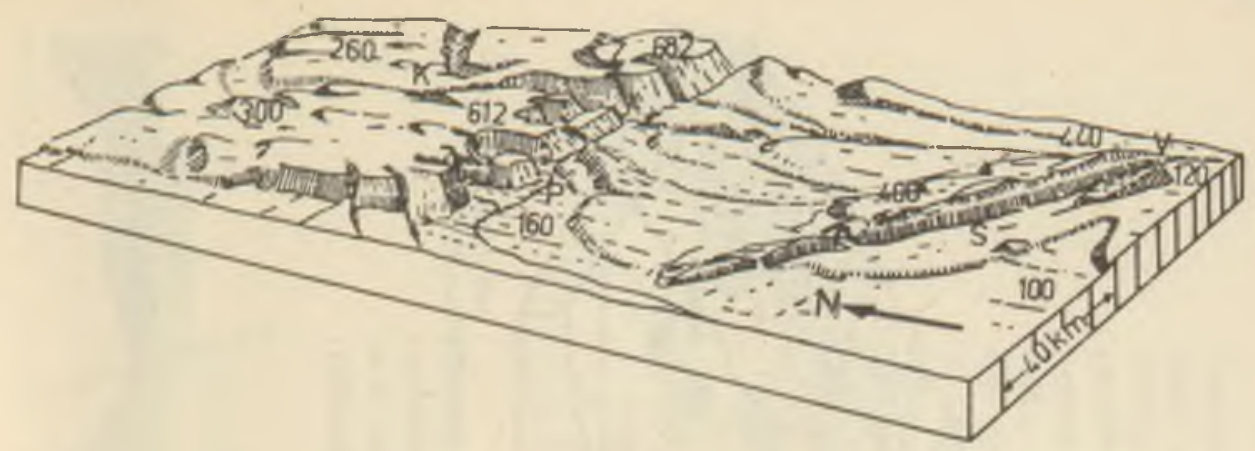

Fig. 13. Relief diagram of the Mecsek Mountains (constructed by Gy. Peja), height in metres. $-K=$ Komló; $\mathrm{P}=$ Pècs; $\mathrm{S}=$ Siklós; $\mathrm{V}=$ Villány; $\mathrm{Z}=$ Zengō Peak

consisting of ranges of thrust-sheets (Figure 13). The heavy structural disturbances of this range make it difficult to mine the good quality Jurassic coals. On the southwestern slopes Permian sandstone crops out, containing uranium ore. The morphology of the territory is characterized by varied forms relief, rich in karstic phenomena, in the Triassic limestones of the mountain's western part. Due to its low elevation the climate of the mountains is quite similar to that of its vicinity. On the southern side steppe-meadows and karst-shrub-forests exist above the vineyards and orchards, while the tops and northern slopes are covered mainly by closed beech and oakwood forests.

The karstic plateau of the eastern Mecsek Mountains absorbe a lot of rain water which reappears on the margins as abundant karst springs. These springs play an important role in the water supply of the vicinity, mainly at Pécs.

The southern slopes of the Villány Mountains are covered by famous vineyards. Plants of sub-Mediterranean character occur locally (sweet chestnut), indicating that this landscape has the warmest summer and mildest winter of all regions in the country $\left\langle\right.$ Cfax $\left.\left(x^{\prime \prime}\right)\right\rangle$.

The vicinity of the Mecsek and Villány mountains is formed by an erosional-derasional hilly country, Baranya, 150 to 300 meters high and of varied structure. At the foothill of the Mecsek Mountains the Holocene subsidence of the Pécs Plain and that of the Villany Mountains, the famous mineral springs of Harkány and Siklós give evidence of young tectonic movements. The basement rock, which varies from Lower Paleozoic granite to Upper Pannonian sediments, is usually covered by a thick loessic blanket on which the most fertile chernozem and chernozem brown forest soils of Hungary have developed. Agricultural production has removed 


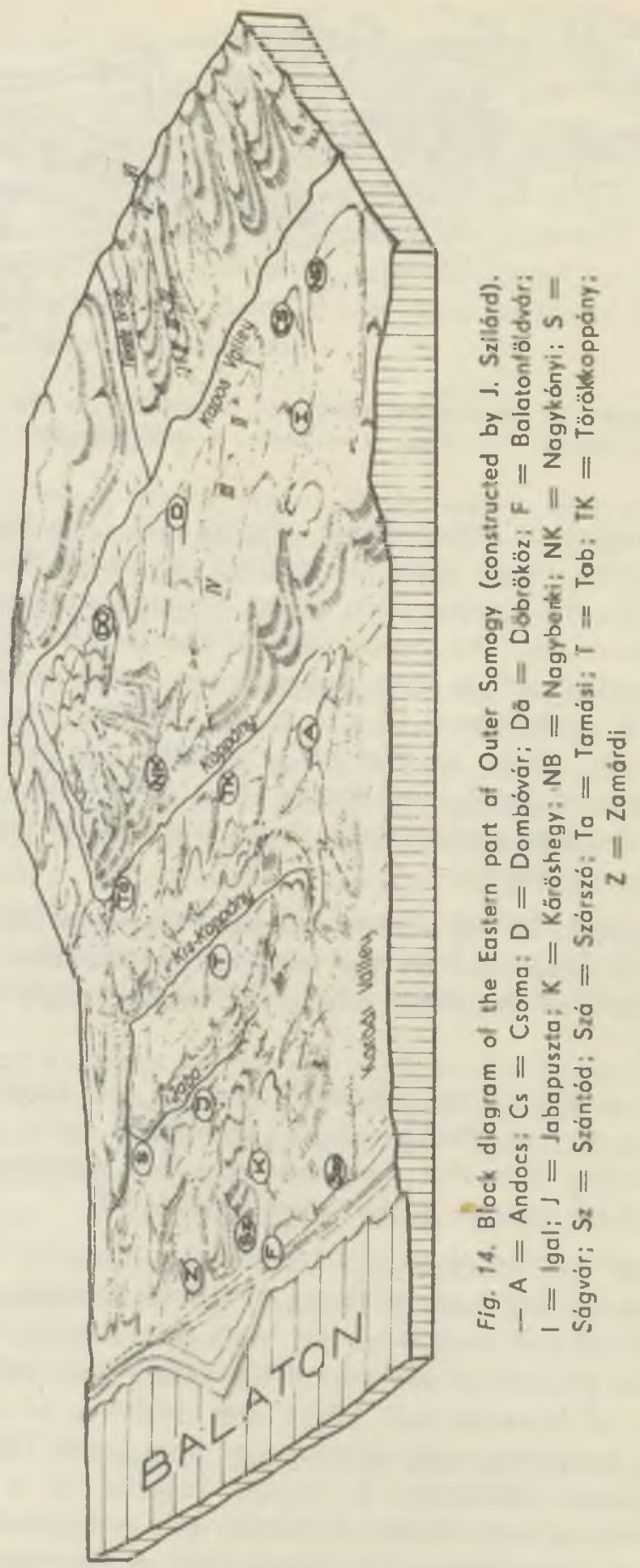



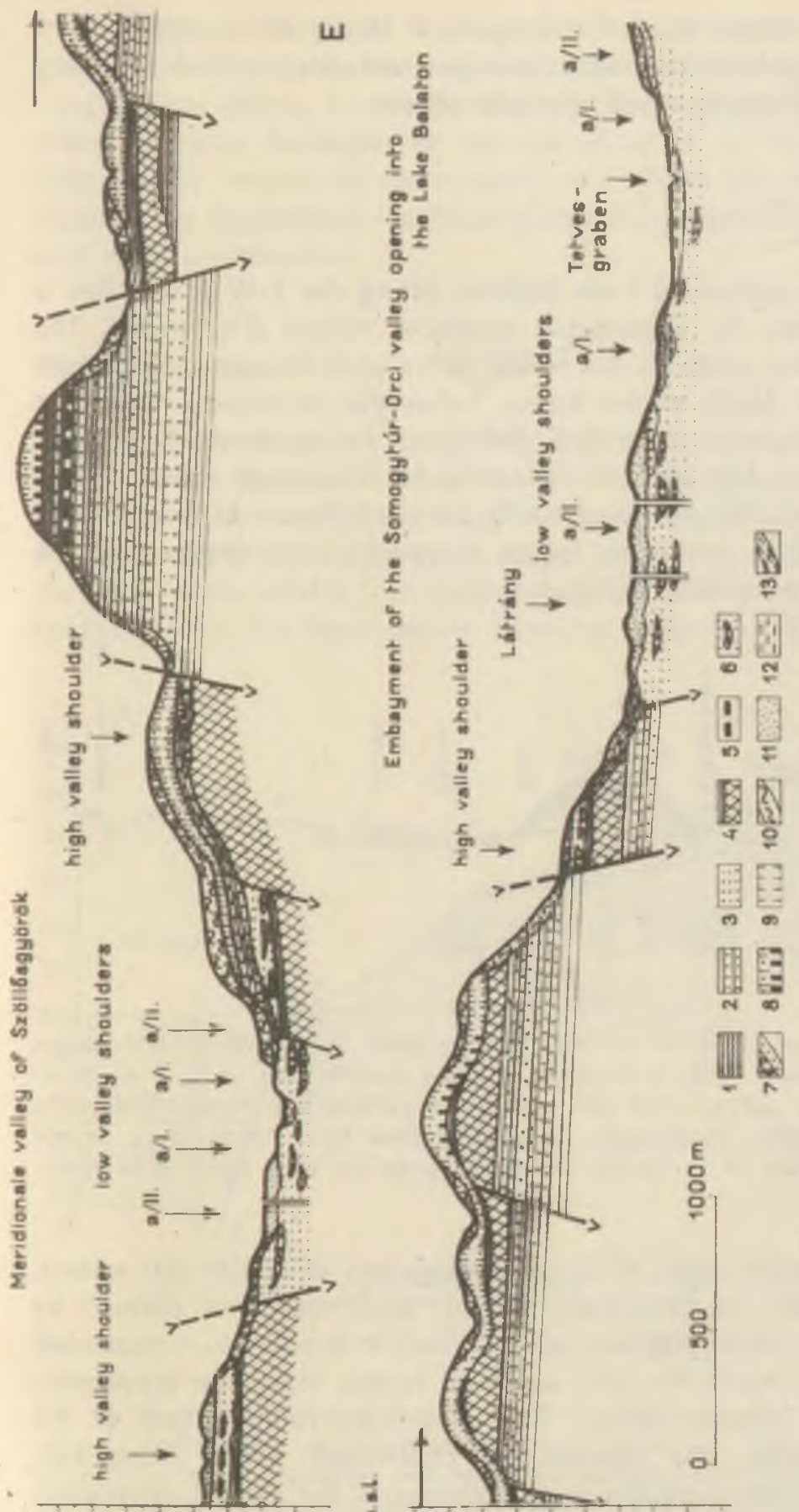

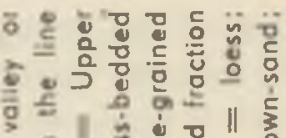

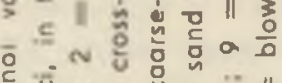
는 $\lambda$ 至

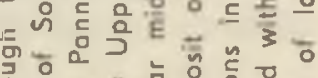

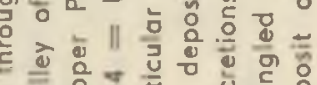
-

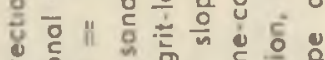

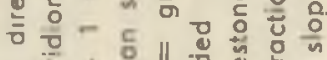
प $3 E$ E 0 。

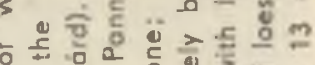

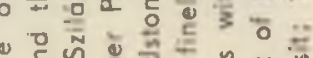

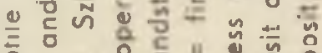

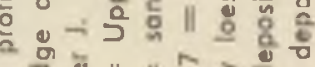
- कृ

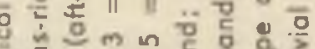
믈 응 웡

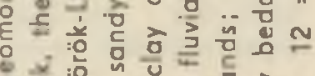
ว : i है ํํํำ

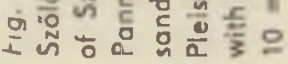

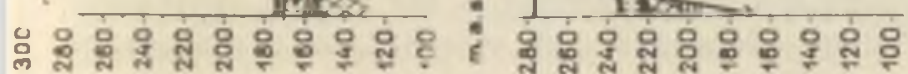


the formerly dense forests but on the northern slopes many groves have been preserved. Its mild winter, warm summer and early arrival of spring also show the sub-Mediterranean climatic effects.

\section{The Hilly Region of Somogy}

South of the young graben of Lake Balaton along the E-W faults, lies a hilly country dissected by asymmetric erosional valleys (Figures 14, 15), which is bordered from south by the broad valley of the Kapos river (Figure 1: meso-region 4.2). South of the Kapos Valley the landscape types are similar but the valleys are in a N-S direction. An ancient alluvial fan covered by thick sand deposits and called the Inner Somogy extends westward between the Lake Balaton and the Drave river (Figure 1: meso-region 4.3). On the basis of its ecological facies, however, it was assigned to the landscape types of the lowland (Figure 16).

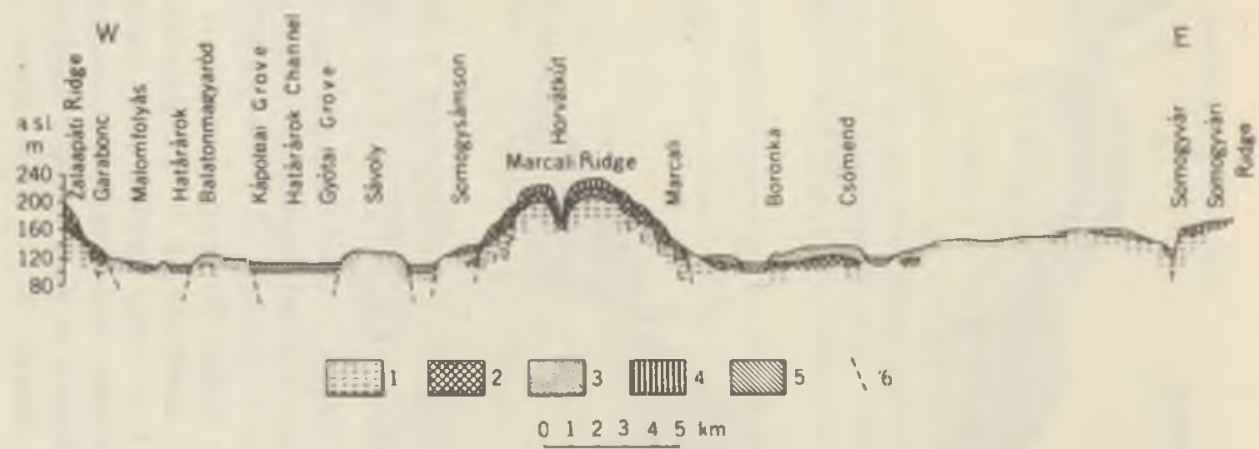

Fig. 16. Geomorphological profile of the Inner-Somogy (after S. Marosi). $-1=$ Upper Pannonian sediments (sand, clay): 2 = Upper Pliocene cross-bedded sand; 3 = Pleistocene fluviatile sand, in general, and with wind-blown surface, and frequently occuring "kovárvány", cryoturbational phenomena; $4=$ Pleistocene loess, sandy loess, on the slopes stratified slope loess: $5=$ alluvial sediments (sand, silt, clay, peat): $6=$ faulty. zone

Where the interfluvial ridges of Outer Somogy are of 250 to 300 meters, the loess cover is thin or completely absent. Such spots are covered by forests. On the grey brown podzolic soil - mainly in the South - expanded sub-mountain beech-hornbeam and oakwood forests show the prevalence of the sub-Atlantic climatic effect. The wide intra-valley ridges of the central part of Somogy are covered by chernozem brown forest soil, moreover, in the eastern part the culture-steppe is the typical chernozem with its arable lands of great extent and with vineyards of the southern slopes. 
The northern margin of the region can be connected to the developing tourist-zone of Lake Balaton, the character and development rate of which considerably differs from that of the hilly landscape lying to the south. More intensive development can be observed in the inner part of the hilly country, mainly in towns and spas. Along the entire shore of Lake Balaton the development is directed by long-term national economic plans. and rapidly increasing.

The Hilly Region of Tolna

Three strongly dissected small hilly areas are closed between the flood plains of the Kapos-Sió-Danube rivers and the range of the Mecsek Mountains. The most dissected part is the Hegyhat located between the Kapos and Sio rivers (Figure 1: micro-region 4.4; Figure 17), and facing the flood plain of the Danube; and the Hilly Region of Szekszárd; while south of them the more gently dissected Völgység (Figure 18) extends to

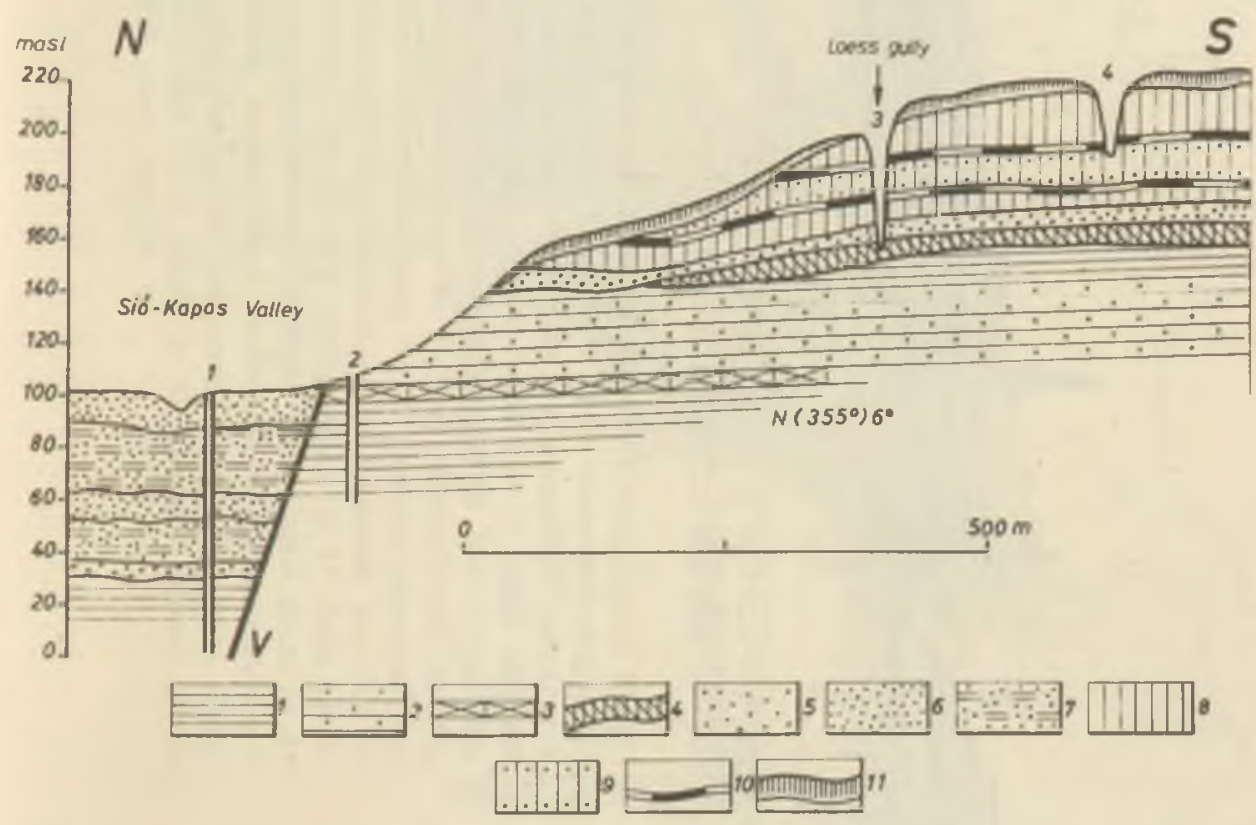

Fig. 17. Geomorphological section of the northern margin of Hegyhat at Simontornya (after L. Adám). - 1 = Ponnonian clay; 2 = Pannonian sand; $3=$ Pannonian sandstone: $4=$ Lower Pleistocene red-clay; $5=$ medium-grained fluviatile sand: $6=$ finegrained fluviatile sand; $7=$ clayey fluviatile sand; $8=$ pale-yellow typical loess; $9=$ pale-yellow sandy loess; $10=$ redbrown fossile soil; $11=$ chernosem; $V=$ fault, faulty 


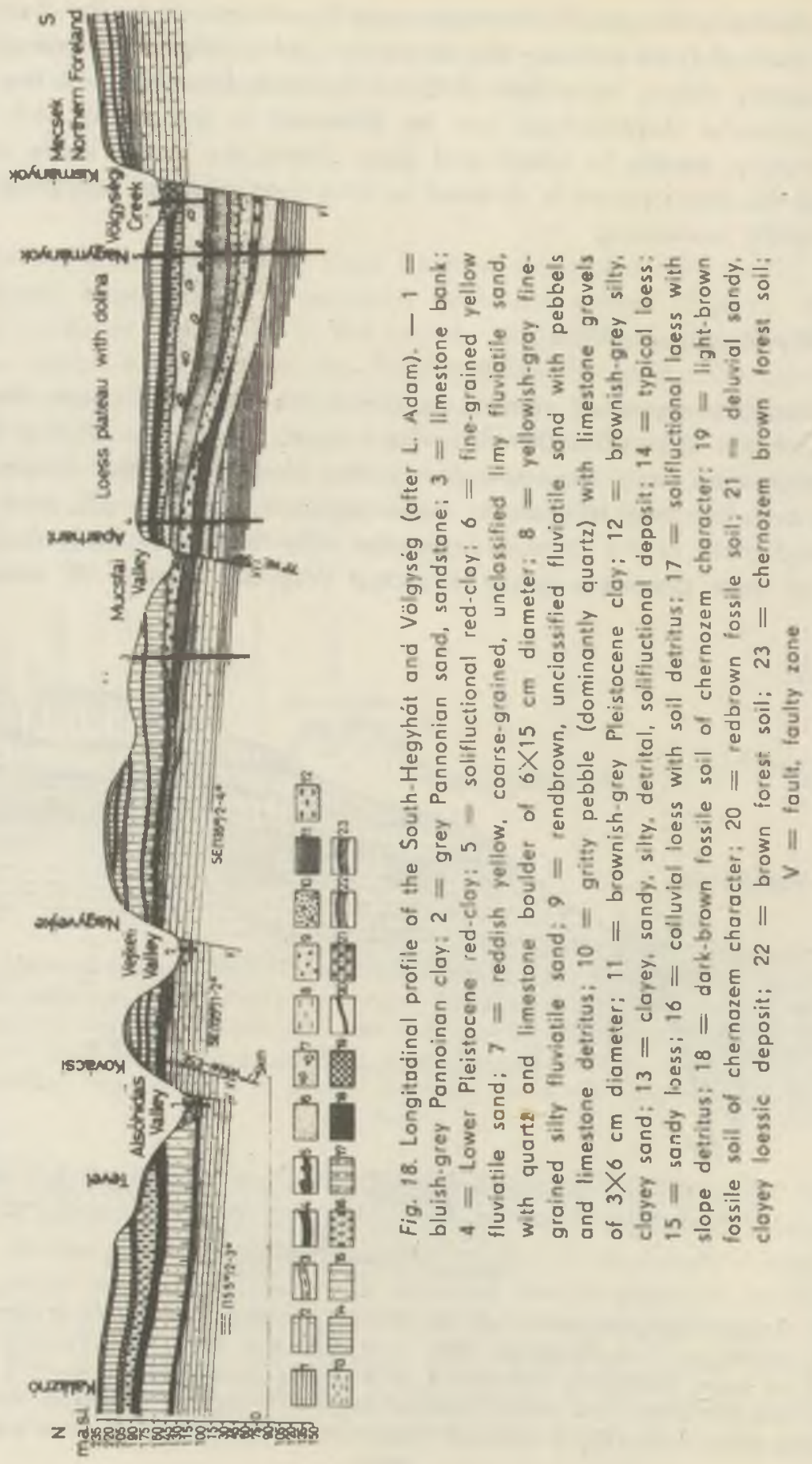




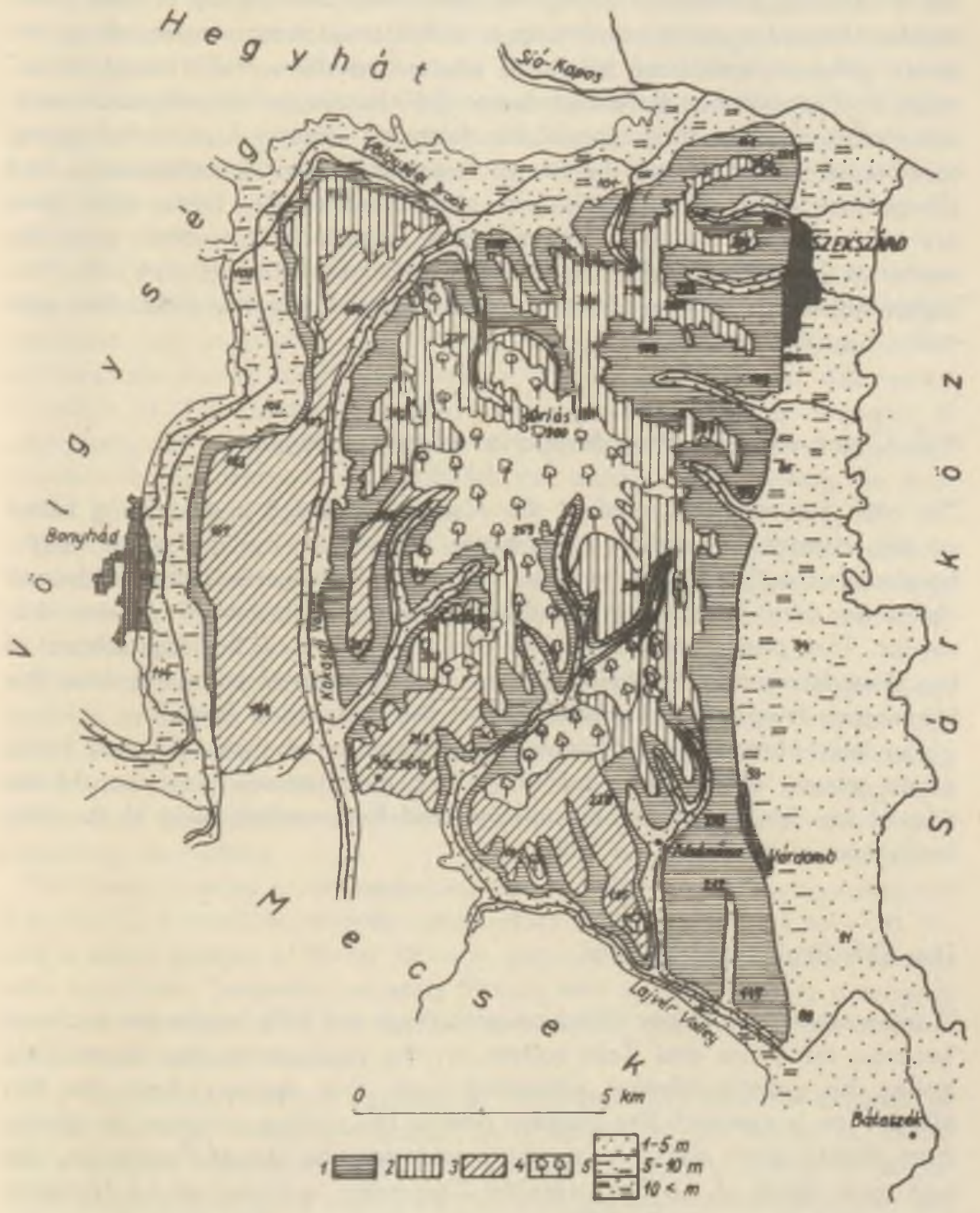

Fig. 19. Soil erosian mop of the Szekszárd Hilly Region (numbers demostrate the percentual measure of erogion of the soil profile) (after L. Adám). $-1=$ area, eroded by about 90-100 percent; $2=$ area, eroded about 30-90 percent; $3=$ area, eroded less than 30 percent; $4=$ non-eroded (covered by forests) area; $5=$ accumulation area 
the Mecsek Mountains. The most widespread formations in the region are the underlying Pannonian beds, but they are covered by a thick loess blanket. Recent tectonic movements and the small watercourses along the dense valley network have produced strong dissection and a rough mesorelief. Soil erosion has increased due to the cleaning of the original mixedoak forests and the cultivation of the dissected surface. Due to the strong continental climate ( $\mathrm{Cfbx}$ ) the brown forest soils, and the chernozem and chernozem brown forest soils are characteristic. All these soil types are of excellent fertility. Administrative, agrotechnical and scientific measures have been taken to prevent soil devastation (Figure 19). The higher elevations of these hilly countries experience some difficulties with water supply.

\section{Hilly Countries of the West-Hungarian Marginal Region}

The high mountainous relief of the Alps has a large and unifying effect on the climate, vegetation, soil, water regime, in its immediate neighbourhoods, so that in the marginal region it homogenizes the landscape character even: though the relief conditions may be more or less dissimilar. This phenomenon explains the separation of the landscapes of the West-Hungarian Marginal Region of hilly country character from the landscapes lying in the internal part of the Pannonian Basin.

The West-Hungarian Marginal Region consists of three different landscape groups: a) the Sub-Alps which is a mountainous lanscape; b) the alluvial fan landscape of Sopron, Vas and Kemeneshát; and c) the hilly landscape of the Vas-Zala Hills.

\section{The Hilly Region of Vas-Zala}

In the westernmost corner of the country, there is a hilly landscape enclosed between the Mura and Zala valleys. In the environs of the Upper Zala Valley the gravelly blanket extending into this territory from the Vas alluvial fan is exposed. The greatest part of the surface is dotted by glacial loam (brown earth sails). It usually is underlain by Upper Pannonian clay and sand. South of the Zala river the Pannonian sediment of the Neogene kratogeosyncline exceeds 4,000 meters in thickness. This thick Pannonian sequence and other Tertiary sediments are the reservoirs of the crude oil deposits of Zala. The crude oil and the associated natural gas, as well as the hyperthermal mineral waters are valuable resources. The hill ranges of this area reach up to 300 meters in height. 
The Zala Hills are characterized by long, linear parallel meridional valleys which formed between the Zala and Mura rivers (Figure 20). These valleys dissect the surface into flat topped uniform ridges of N-S strike. The origin of the meridional valleys, bordered by uneven, sloping sides, is a much debated question. They were deepened with fluviatile erosion along the structural lines and widened because of the effect of the wind and gravitational downslope movements. When crossing the Zala Hills in an $\mathrm{E}-\mathrm{W}$ direction perpendicular to the valleys, one may have the impression of travelling on a switchback railway.

On the hill tops oak-pine-acacia forest patches of various sizes alternate with arable lands. The valley floor is composed of waterlogged meadows and grassland, and in large valleys it consists of peat. In the southwestern corner of the country the Vasi-Hegyhát rises to 400 meters in height. It is a strongly dissected hilly landscape with the remnants of seven terraces of the Rába (Figure 21). It largerly is covered by mixed forests with a characteristically sub-Atlantic undergrowth showing the most varied composition in Hungary.

The valleys in Zala can still be characterized by the valley waterscheds. The water flows both north and south, or it is stagnant and its drainage is uncertain. The most significant meridional valley in Zala is the valley of the Principalis Canal.

The landscape and its types are not too varied. On the ridges pseudogleyic and grey brown podzolic soils have developed, which towards Lake Balaton grade into more weakly leached forest soil with a decreasing precipitation. In the valleys between two hill-ridges meadow and bog soils occur. Due to abundant precipitation soil erosion is active on the slopes bordering the valleys.

The local climate is characterized by a mean annual temperature of 9 to $10{ }^{\circ} \mathrm{C}$, a medium monthly temperature fluctuation of -1 to $+20{ }^{\circ} \mathrm{C}$, and a water budget of 50 to $150 \mathrm{~mm}$. gain $\left\langle\mathrm{Cfbx}\left(\mathrm{x}^{\prime \prime}\right)\right\rangle$. The winter usually lasts from early December to early March, with a snow-bianket averaging 8 to $10 \mathrm{~cm}$ thick. With the tempestous winds snow-drifts and summer thunder storms are frequent.

The landscape is of an agricultural character. The hamlets situated at regular intervals, usually are located in a water-rich river valley, but avoid the wet valley floor endangered by inundation. In the vicinity of larger towns a broad intensively cultivated fruit-and vegetable-producing zone has developed. The apple is the most common fruit, and mainly in the southwestern region, the apple orchards are common ecological elements on the hill sides. It is only in this region of Hungary that locally produced timber is used as building material on a large-scale though the ancient log-walled houses have now been mostly removed from their original sites. 


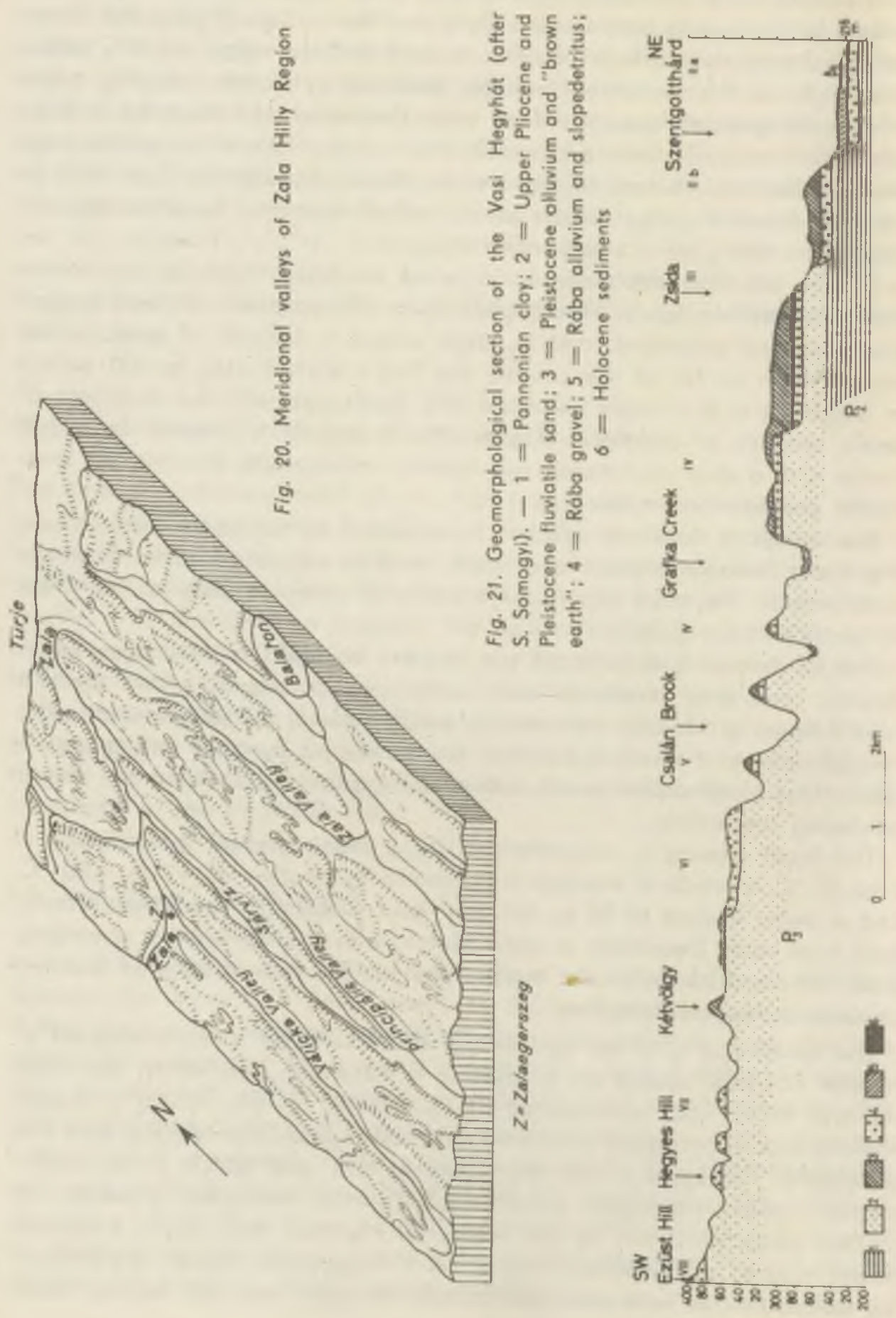


From the point of view of typology the relief is most essential of all the natural characteristics. The height above sea level and the structuralmorphological types, as well as the variability of exposition and angle of slopes (together with the lithological characteristics) of the relief control the other landscape-forming natural factors. In such a way, for instance, the increase of the height above sea level or the increase of the slopes facing the north cause cooler and more humid micro- and macroclimates. These factors also cause further changes in the quality of the soil and vegetation and in the character of the landscape. Therefore, in the reliefbased classification of the Hungarian mountainous landscape types, two mountainous landscape type groups have been distinguished:

(a) Types of the low mountains

(b) Types of highlands

The most common and most essential characteristics are: the markedly mosaic-pattern of the ecological facies; the relative richness of mineral resources and mine products; uneven topography; very high relief energy, drainage coefficient of high percentage which cause an increased danger of erosion; the increase of the role of the micro- and mesoclimates and the mass occurrence of the intra- and extrazonal vegetation and soil.

The types of the low mountains can be found between the 300 to 350 meter elevation of the rolling slope surfaces and the 650 to 700 meter heights of the central mountains of medium height. These types are characterized by dense woods where zonal Turkey-oak, and hornbeamoaken woods predominate. On the basis of the climatic character, the low mountains can be further subdivided into four subgroups:

a. The low mountain types under the influence of the more extreme subcontinental climate, occur in the macro-region of the North Hungarian Mountains. The most widespread ecological type characterized by the grey brown podzolic soil, developed on the dissected volcanic bedrocks (Visegrád, Börzsöny, Cserhát, Mátra, Karancs, Medves und Tokaj-Zemplén mountains). This type of mountain is always less marked morphologically and is constituted by carbonate rocks and carrying mainly rendzina and grey brown podzolic soils, as well as characteristic karst forms (eastern Bükk Mountains, Aggtelek Karst, Uppony Mountains, etc.).

b. The second type of the low mountains affected by the sub-Mediterranean climate with double precipitation maximum, occur in the Transdanubian Mountains. Among them the types constituted by carbonate rocks and having rendzina and grey brown podzolic soils, are frequent. Besides them the ancient karstic barren landscapes are secondarily expanded and at present they dominate the landscape in many places 
(Villány, Mecsek, and Keszthely mountains, Eastern and Southern Bakony, Southern Vèrtes, Gerencse, Buda, Pilis mountains, etc.). In this group the type of crystalline block-mountains is of small extent (Velence Mountains).

$c$. The third type of the low mountains, affected by the more humid subAtlantic (Middle European) climate which developed in the territory of Transdanubia. The types of the mountains of volcanic origin and of the block-mountains, covered with erubase and strongly acidic brown forest soils, can be found in the Sub-Alps (Köszeg-Sopron mountains) as well as in the western margins of the Transdanubian Mountains (basaltic mountains of the Balaton Highlands).

d. The northern, precipitation-collecting margins of the mountains of carbonate bedrock form the other type of this group. They are usually covered with brown forest soil and beech forests can also be found on them (Western- and Northern Bakony Mountains, Northern Vèrtes Mountains, etc.).

The landscape types of the highlands (between 650 and 1000 meters above sea level) can be found in Hungary only occasionally in the North Hungarian Mountains. This type group of a true mountainous character is characterized by a rather humid climate (Central European, sub-Atlantic). Its closed forests are generally beeches. One of its types is the strongly dissected summit level of the volcanic mountains with eurbase and slightly podzolic brown forest soils (High-Börzsöny, Central Mátra, and Northern Zemplen mountains). The other type is the sligthly dissected karst-plateau covered with rendzina and brown forest soils (High-Bükk mountains). These highest landscapes of Hungary are utilized by forestry and recreational facilities.

\section{The montainous landscapes of the Sub-Alps}

The basin of the Little Plain is bordered on the west by the Sopron- and Köszeg mountains which are the easternmost blocks of the crystalline range of the Eastern Alps, isolated from one another and extending into the territory of Hungary. The southern trough-like depressions of the Little Plain - the Rába Valley and the Marcal Basin - separate the foothills of the Alps from the Transdanubian Mountains to such an extent, that there is little structural connection between them.

The Sopron Mountains are a part of the Paleozoic crystalline bedrock. Its highest point is only 558 meters. It is really a portion of the Rosalia Mountains, which lie in Austrian territory, and is a separate block of the crystalline schist zone of the Eastern Alps. It is composed mainly of Lower Paleozoic gneiss and partly of mica-schists but its lower slopes are covered by a thick sheet of Tertiary sediments. 
Level to gently sloping land-forms are characteristic of its relief. The valley troughs form moderately steep slopes which, along with the flat ridges, are covered by beautiful beech and pine woods.

The cultivated areas of the region extend to the high slopes. The vicinity of Sopron is famous for vineyards and wines.

The fertile Sopron Basin separates the slightly elevated flat crystalline Balf-block on the western shore of Lake Ferto, from the Sopron Mountains.

The Köszeg Mountains rise south of the Sopron Mountains, at the western frontier of Hungary. They also are remnants of the Paleozoic crystalline basement complex. The Bernstein Mountains connect them to the Styrion Alps in Austrian territory. In the backbone-shaped continuous block of the Kõszeg Mountains is the highest point of Transdanubia, the Irottkö (882 meters). On the eastern side of the mountains built up by Paleozoic schists, the deeply incised valley is dissected into secondary crests.

The vegetation of the area is varied. At the bases of the eastern slopes oakwoods and chestnut woods are located and in the higher parts beech and pine woods can be found. Lower hills, covered by vineyards and arable lands, join the eastern bases of the mountains.

The area of the Sopron and Köszeg Mountains receives the most moisture in Hungary. The annual precipitation is 900 to $1,000 \mathrm{~mm}$. The distribution of precipitation is equable. The effect of the humid oceanic air masses, arriving from the West, is manifested by early summer and late autumn maximums, as well as by the temperate climatic conditions (Dfbx'). The balanced character dominates in the climate, and these landscapes are among the mountainous landscapes of Hungary the least liable to extremism (Figure 1: 3.1).

\section{The Transdanubian Mountains}

The low mountainous landscape of 400 to 500 meters average height is a block-mountains range which consists mainly of Mesozoic limestones and dolomite. The groups of the Transdanubian Mountains of SW-NE strike consisting of uplifted horsts, are dissected by various sized basins with a hilly country character. The single groups are separated from one another by graben valleys of NW-SE direction perpendicular to the mountain strike. The surfaces of the uplifted blocks, elevated in different heights along the faults, are landscapes of forestry type. The hilly inter-mountain basins are mainly utilized as arable lands, while the basins of marginal position, where the Lower Tertiary marine sediments contain brown-coal beds, are landscapes of a mining and industrial type. 
The natural resources and mosaic-like character of he Transdanubian Mountains, consisting of horst-like blocks and basin-sculpturing hills, ore the results of geo-historic evolution. The rocks of South-Alpine facies, consisting mainly of Triassic limestone and dolomite, have accumulated in the sea-trough of crystalline basement, which subsided at the end of the Paleozoic era, and which emerged for the most part, at the end of the Triossic period. In the area of the mountains the graben-like depressions and horst-like blocks alternated differentially in space and time. The Jurassic-Cretaceous and Tertiary open seas transgressed several times over the marginal zones. In the Cretaceous period the mountains were still relatively uniform and of greater extent than they are at present. Under the tropical climate their surface was reduced to a peneplain of lower position by the planation processes. This fact is proved by the bauxite beds buried in several places into the basins during the Tertiary period, whereas other bauxite deposits were uplifted. At the end of the Cretaceous period and during the Paleogene period loose sediments and coal-beds accumulated in the subsiding depressions and bays.

The horsts surrounding the bosins in the Transdanubian Mountains underwent a dra. matically colourful evolution during the Tertiary period. Among the summit surfaces surpassing 500 meters in height there are mountains which since Late Cretaceous epoch have risen above their background and endured policyclic denudation. Others were covered with Tertiary sediments (gravel, conglomerate, sand and limestone, marl, etc.) and in the later phases of their evolution they became partly or totally exposed. Among the Mesozoic mountains there occur both exposed horsts and blocks covered by Tertiary sediments. Later, in the Pliocene epoch, basaltic lava-sheets deposited on certain blocks of the Bakony Mountains.

Till the end of the Miocene epoch, the northern and southern regions of the Transdanubian Mountains were surrounded by a higher crystalline bedrock mountain, which gradually hos subsided since the Late Miocene - Early Pliocene. Its remnants are the Velence hills in the foreland of the Vertes Mountains, and the Paleozoic phyllites which crop out in the Balaton Highlands. The whole Tarnsdanubian Mountains also emerged from the Pliocene-Pannonian sea as a peninsula, as the sea transgressed locally over its margins, and in several places it produced abrasion terroces on the sides of the blocks.

The present features of the Transdanubian Mountains have been controlled by the uplifts which took place in Late Pliocene and Pleistocene ages. In this period intermountain and piedmont foothills were formed and were dissected later by rivers.

Lying north of Lake Balaton, the Bakony Mountains are the largest member of the Transdanubian Mountains (Figure 22). Their block, which separate into groups, are isolated or rather connected to one another by numerous inter-mountain and mountain-margigal basins. The greater part of the low mountains, consisting mainly of carbonate rock, is affected by the sub-Mediterranean climate, while its closed inter-mountain basins have a more extreme climate. The parts facing the dominanting NW wind are affected by the rain-collecting sub-Atlantic climate (Dfbx). Large, flat dolomite plateaus, usually formed by planation, are characteristic. The other group of the blocks is a buried karst landscape. The basins and grabens between the blocks are filled up with sediments, as well as with bauxite and manganese ore and brown coal. The Tapolca Basin, famous for its basalt-capped buttes, is of dissimilar character and is the wellknown separate micro-region of the Bakony (Figure 1: meso-region 5.1). 


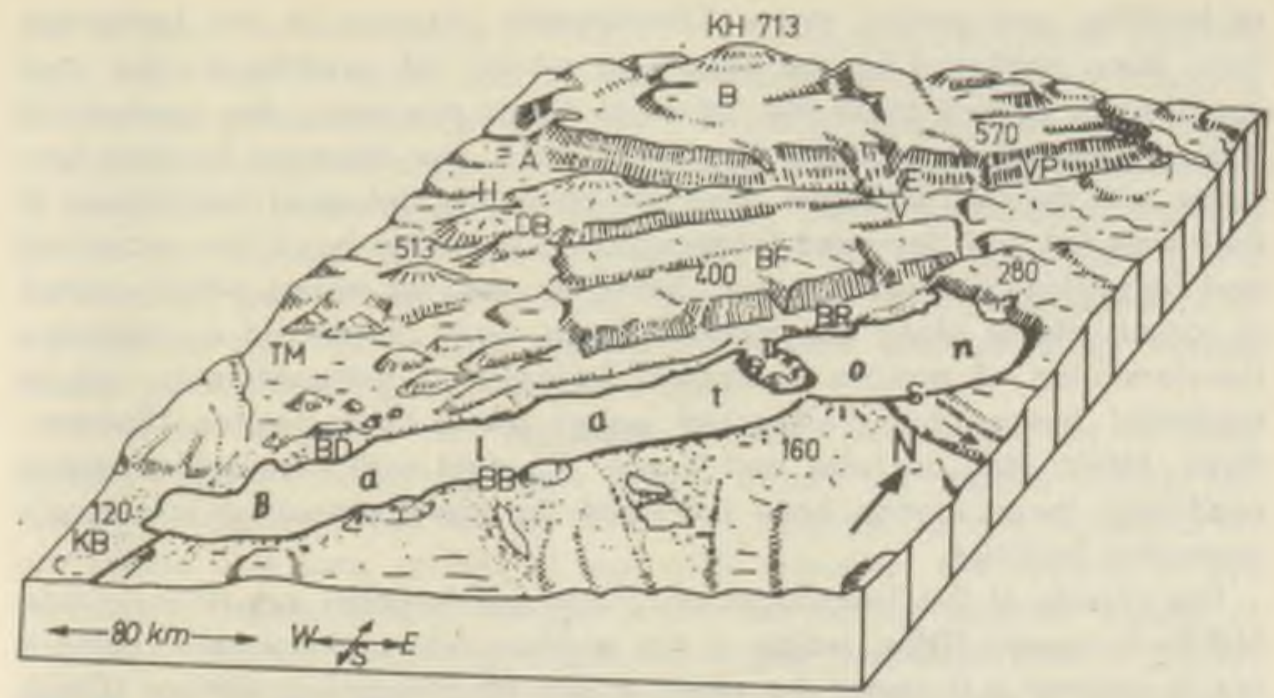

Fig. 22. Relief diagram of the Bakony Mountains and of Lake Balaton (constructed by Gy. Peja), height in metres. $-A=A j k a ; B=$ Northern Bakony: $B B=$ Balatonboglár: $\mathrm{BD}=$ Badacsony; $\mathrm{BH}=$ the Balaton Highlands; $\mathrm{DR}=$ Balaton Riviera; $\mathrm{DB}=$ Southern Bakony; $E=$ Eplény; $H=$ Halimba $\mathrm{KB}=$ Little Balaton; $\mathrm{KH}=$ Mount Köris; $\mathrm{S}=$ Siófok: $\mathrm{T}=$ Tihany: $\mathrm{TM}=$ Tapolca Basin: $\mathrm{V}=$ Veszprém: $\mathrm{VP}=$ Várpalota

The uplifted horst of the Vértes Mountains is one of the most closed units of the Transdanubian Mountains. Poor in superficial watercourses, this karstic landscape is covered with Turkey-oak and hornbeam-oak woods, but its north-facing dolomite slopes are ancient natural barren lands in which the rich sub-Mediterranean vegetation indicates the character of the climate. Its large bauxite and brown coal deposits are important mineral resources (Figure 1: meso-region 5.2).

Northeast of the Vértes, the Dunazug Mountains connect the blocks of the Gerecse-Buda-Pilis Mountains which alternate like a mosaic, with small basin-sculpturing hills (Figure 2). The characteristics of the part of the Transdanubian Mountains near the Danube Bend approach those of the macro-region of the North Hungarian Mountains. Budapest, the capital of the country, has developed on the eastern margin of the Buda-Pilis Mountains. These mountains are of inestimable value as health resorts and tourist attrations.

The mineral resources of this region, primarily bauxites and manganese ores, as well as brown coal, which are located mainly in the basins of the hilly countries, are an important source of power for the entire country. The morphological pattern of the landscape has been considerably influenced by the human society, especially with the large-scale extraction 
of building and paving stone. Considerable changes in the landscape have been produced by the open-face mining of bauxite, by the coal spoil-banks, as well as by the industrial plants processing the products of mining (Gánt, Dorog. Tokod, Tatabánya, etc.). The chemical fertilizer factories with their air pollution have disturbed the biological equilibrium of their vicinities and destroyed landscape. On the other hand, the recreation and balneological centres (spas), based on the hot waters which ascend in various places along the marginal faults, have resulted in a landscape transformation of positive character. Budapest is extraordinarily rich in medicinal springs, but the thermal waters along Lake Balaton (Balatonfüred, Héviz, etc.) are also well-known. Coupled with favourable natural conditions these springs have promoted the development of large-scale recreation facilities.

The climate of the Transdanubian Mountains is partly sub-Atlantic and Middle European (Dfbx, mainly in the southwestern and northern regions), but in general it is under the effect of sub-Mediterranean climate (Cfbx). The quantity of annual precipitation varies between 600 and $800 \mathrm{~mm}$., the temperature is milder and less extreme than in the eastern part of the country. The winter is cold and snowy, the summer is cooler and not droughty. The snow-cover is thick and steady mainly in its northern and southern parts, and snow-drifts, caused by the wind of dominantly NW direction, are frequent. The marked relief increases the possibilities for the development of meso- and micro-climates, which locally may strengthen or weaken the zonal climatic effects.

The different varieties of forest soils are the main soil types of these landscapes. On the limestone and dolomite surfaces shallow rendzina

A

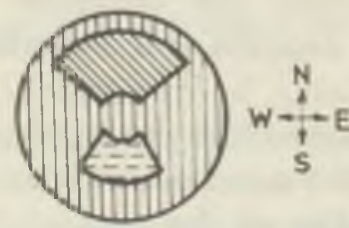

B

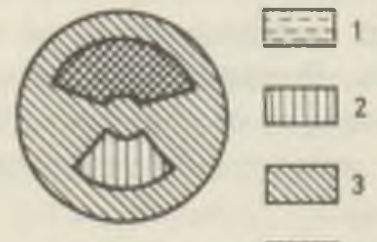

C

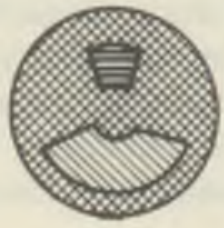

Fig. 23. Plant associations according to exposure of a coenical mount in three forest zones of the Hungarian Mountains (schematic representation) (after P. Jakucs). $A=$ in oak forest zone; $B=$ in oak-hornbeam forest zone: $C=$ in beech forest zone ; $1=$ steppe, shrub forest; $2=$ oak forest the mountains; $3=$ oak-hornbeam forest; $4=$ beech forest: $5=$ coniferous forest 
can be found, while in other places brown earths and grey brown podzolic soils with clay illuviation occur. On bedrocks more liable to leaching (sandstone) pale acidophilic soils also may occur in large patches. Due to strong morphological dissection soil erosion and even the development of completely barren lands are frequent. The barren landscapes also are due to the relative relief attaining of 500 to 600 metres (mainly in the northeastern part of the landscape), to the poor forestry management of the past as well as to the peculiar cultivation method using narrow private plots extending high up the slopes.

The water budget of the landscape is rather poor, especially in those places where the carbonate rocks rapidly absorb the surface waters. The run-off coefficient is as low as 15 to 18 percent. Surface watercourses are sparse and karst springs of high yield occur on the margins of the mountains. Thanks to Lake Balaton which lies on the southern border of the Transdanubian Mountains and is the largest freshwater lake of Central Europe, the Balaton Highlands area has developed into one of the largest recreation district of Hungary.

The natural vegetation of the whole mountainous landscape belongs to the zone of the oak and hornbeam-oak woods and beech-forests, according to hypsometric levels. The southern slopes, rich in sub-Mediterranean plant species, carry extrazonal thermophilous oakwoods, karst-shrub forests and associated mosaic-like culture steppes are flourishing. On the northfacing slopes of remnant character, high-mountain plants and vegetation types may also occur, mainly on dolomite bedrock. Nearly half of the landscape is forest-clad (Figure 23).

Comparatively intensive agricultural cultivation is conducted only on the marginal slope-pediment and in the inter-mountain basins, its character being the same as that of the Transdanubian Hilly Region. The viticulture and fruit-production are significant, especially on the meso-climatically warmer slope-pediments of the Balaton Highlands which enjoy a higher isolation.

Its landscape types are distributed in accordance with the morphological fundamentals as well as with the climatic and vegetational zones. Depending on the lithological characteristics these types are further refined by differences in soils, exposition, slope conditions, and qualitative and quantitative characteristics of the anthropogenic impact. In the Transdanubian Mountains the low central mountain types are predominant, as shown previously in Fugure 2. Most important are the following:

- The landscape type which is characterized by sub-Mediterranean climate, flat topped limestone and dolomite bedrock covered with rendzina and grey brown podzolic soils (Keszthely Mountains, Eastern and Southern Bakony, Vẻrtes, Gerencse, Buda and Pilis mountains). 
- The low mountain types characterized by sub-Atlantic climate, low plateaus of carbonate bedrock covered with brown forest soil (Western and Northern Bakony and Northern Vertes mountains).

- The landscape type of the volcanic monadnocks covered mainly with erubase soils and characterized by sub-Atlantic climate (Buttes of the Tapolca-environs).

\section{The North Hungarian Mountains}

This macro-region can be regarded as the northeastern continuation of the Transdanubian Mountains, but it differs from them in several important fundamentals. It is closely connected to the Carpathians and extends past the border. Its connection with the Carpathians is obvious in the structure of its individual sectors, in the climatic character, in the vegetation, etc.

From the structural-morhological point of view, two types of mountains can be distinguished:

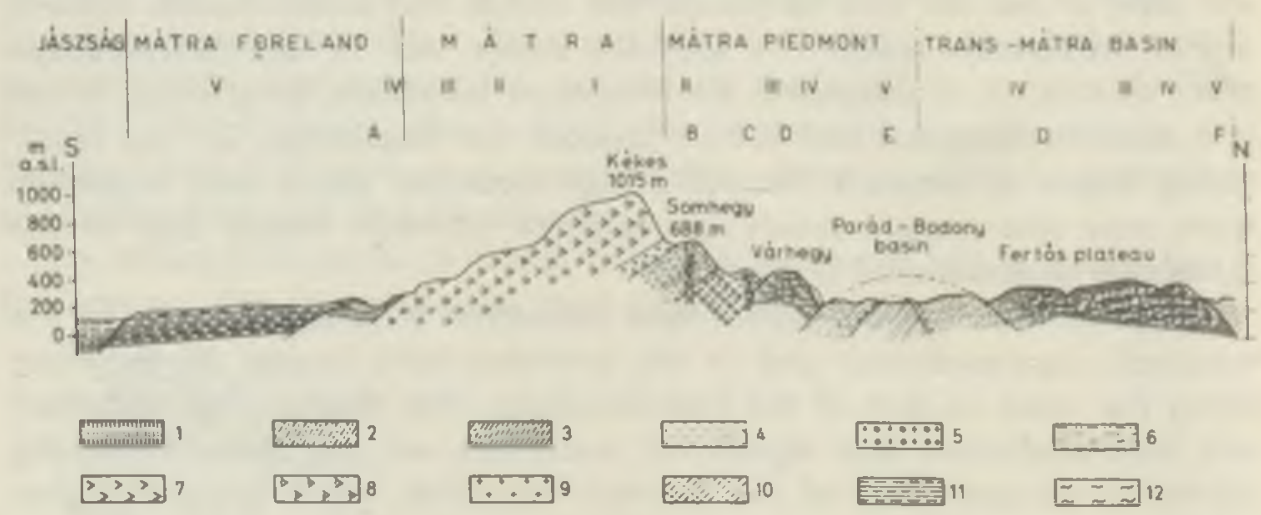

Fig. 24. A comprehensive synthetic profile of the Mótra Mountains (after A. Szekely). 1 = Middle Oligocene schlier; 2 = Upper Oligocene (Lower Chattian) schlier; $3=$ Upper Oligocene hard sandstone; 4 = Upper Oligocene (Upper Chattian) schlier, less thoroughly consolidated; $5=$ Lower Miocene varicoloured clays, soft sandstone, Lower Rhyolite tuff, lignite formation; $6=$ Helvetian schlier; $7=$ Etched-out subvolcanic bodies (lacooliths, dykes); $8=$ Tortonian volcanites (andesite, agglamerate, tuffs); $9=$ Middle Rhyo-dacite tuff; $10=$ Sarmatian clay, marl, reworked tuff, etc.; $11=$ Upper Pannonian clays, sands, deposits of the Pannonian inland sea: 12 = Quaternary alluvial fans, slope deposits etc. Planated surfaces: I = High surface; II = Upper step; III = Middle step: IV = Upper Pliocene pediment-like lower step; V = Loker Pleistocene glacials of erosion and accumulation. $A=$ Structurally controlled small basins of the Mátraaljo; $B=$ Upper string of laccoliths; $C=$ Lower string of laccoliths; $D=$ Plane on Upper Chattion sandstones: $E=$ Basins of denudation of the foot of the Matra: $F=$ Basins of denudation beyond the Matra 


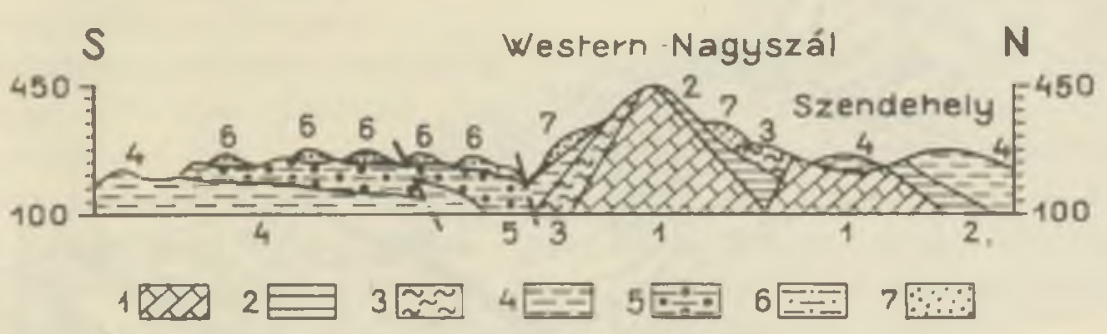

Fig. 25. Profile of the western part of the Nagyszal (Cserhat Hills) (after J. Noszky, 1940 - S. Láng, 1967). -1 = Triassic formations: 2 = Eocene formations: 3 = Rupelian; $4=$ Chattion; $5=$ Helvetian; $6=$ Tortonian formations: $7=$ loess

a. The remnants of the Neogene strato-volcanoes which belong to the Inner-Carpathian Volcanic Chain;

b. The Mesozoic fault-folded block-mountains.

The range of the volcanic mountains actually begins with the Visegrád Mountains lying in the Danube Bend. Other members of the range are the Börzsöny and Mátra Mountains which are well separated from their surroundings (Figure 24). These two mountains encircle the Cserhát Mountains of hilly country character (Figure 25) which is a micro-region of several volcanic and Mesozoic block-mountains loosely linked to one another. The members of the volcanic mountains mentioned above generally are built up by lavas, tuffs and agglomerates of andesites. In the Tokaj-Zemplèn Mountains andesites, rhyolite lava and tuffs are the mountain-forming rocks.

The flat ridges and crests of the volcanic mountains are 650 to 1,000 meters a.s.l. These are the representatives of the highlands. They are surrounded by the 350 to 550 high zone of low mountains, which also are markedly dissected by valleys. The volcanic groups of the Cserhat Mountains can be ranked entirely among the low mountains.

All of the volcanic mountains are surrounded by a moderately sized piedmont zone* 250 to 350 meters high, mainly consisting of Tertiary loose sediments or volcanic lavas.

The faulty-folded Mesozoic block-mountains, the Bükk Mountains and the North Borsod Karst, form an independent mountainous landscape (Figure 1: meso-regions 6.4, 6.5). Both lie on a Paleozoic basement complex. Their evolution is similar to that of the Transdanubian Mountains.

* It is a pediment dissected by intervalley ridges in Late Pliocene and Early Pleistocene ages: while the low mountains zone seems to be the high remnant of an older pediment which probably was formed in the Early Pliocene age. In morphogenetic sense, the summit level of the volcanic mountains also is a planation surface, it is a structuralerosional remnant of old volcanic explosion centres. 


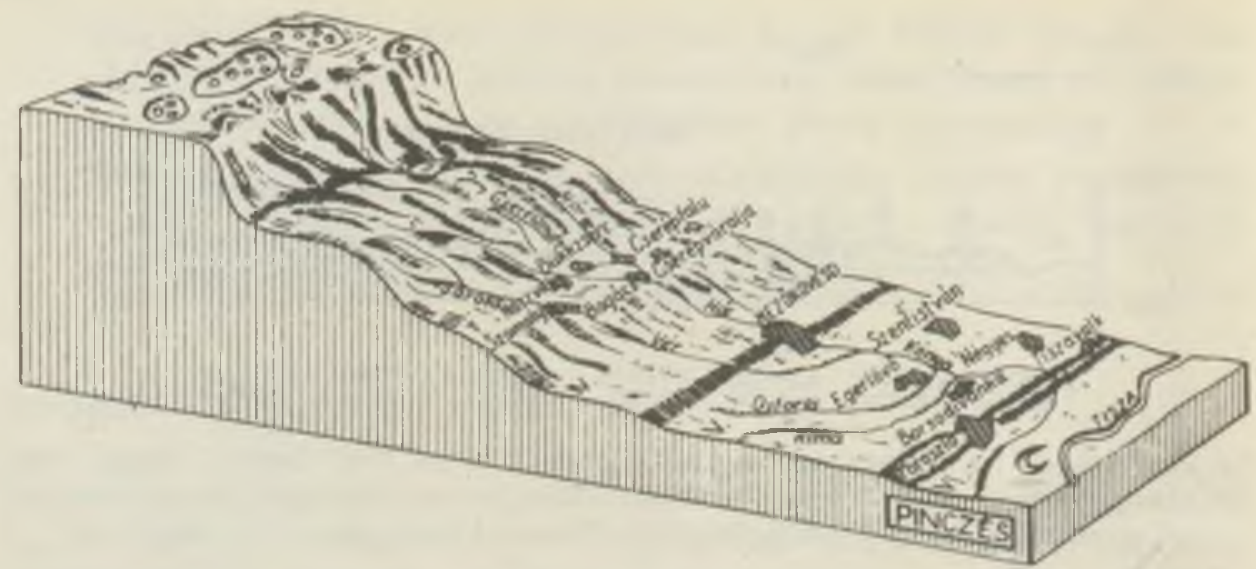

Fig. 26. Morphological profile from the foothills of the Bükk Mountains (after Z. Pinczes). - I = High Bükk (Lower and Middle Eocene surface); II = Middle Bükk: III = Lower Bükk (upper Pliocene foothill surface): IV = Foreland of the Bükk (Early an Middle Pleistocene alluvial fan; $V=$ Borsod Plain (Late Pleistocene alluvial fan): $V I=$ Floodplain of the Tisza River on the Borsod Plain (Holocene)

The central planated surface of the Bükk Plateau (900 meters average height) is surrounded by a lower planated surface (650 to 750 meters). which is followed by a low mountain zone ( 300 to 400 meters high). This area actually is the Upper Pliocene pediment, strongly dissected by valleys. Then a gently dissected Quaternary alluvia 1 fan joins it towards the Great Plain (Figure 26).

The Hungarian portion of the Aggtelek Karst, 500 to 600 meters in height is an old planated block-mountain, partially covered by a young sediment mantle, and partly exposed. The most typical karstic landforms of Hungary have developed in the Bükk Mountains and in the Aggtelek Karst. The multilevel, 22 kilometer-long Aggtelek cave which is famous all over Europe for its wonderful stalactites and stalagmites and for its gigantic karstic halls, is part of the North Borsod Karst.

The North Hungarian Mountains have a varied mosaic-patterned relief due to the peculiar tectonic structure and lithology and petrography of this territory. The mountains are characterized by rough morphology, by limestone masses (Bükk Mountains, Aggtelek Karst), by large continuous

Like the Transdanubian Mountains, the North Hungarian Mountains with their rich forests, energy resources and various industrial raw materials, provide important basis for the country's industrialization. The scenic beauty and mountainous character of the individual landscapes make the whole region an attractive tourist and recreational area. Its higher parts have forestry landscapes, and its lower and marginal zones offer promising potential, for large-scale agricultural development. 
plateaus interspersed with surface and by subsurface karstic landscape forms. These mountains contain peaks above 900 meters and are the highest relief in Hungary.

This area is valuable because of its abundant mineral resources (precious metals, iron ore, kaolinite, bentonite, perlite, gypsum, etc.). Energy resources are also considerable particularly in the marginal areas where brown coal and lignite as well as crude oil and natural gas are found. The building and paving stones of this landscape also supply the regions of the Great Plain. The industrial plants, based on local mineral resources, are transforming the adjacent original landscape.

The climate of the North Hungarian Mountains is more extreme and more continental than that of the Transdanubian Mountains. This can be explained not only by its comparatively easterly position, but also by the direct contact with the Great Plain. This region in general has a landscape with Dfbx climate. The number of the winter and severe days is the highest (above 40 and 20 respectively) the total number of heat days $(10)$ is the lowest with regard to the national average. The annual precipitation is 600 to 800 millimeters, with an early summer precipitation maximum. The rough relief has produced a varied landscape responsible for the development of very diversified micro- and meso-climates which are of great importance for the entire region. On the north-facing slopes mountainous conditions may prevail while on those facing the south conditions characteristic of the lowlands exist.

The hydrography reflects the interactions of the relief, lithology and climate. The run-off coefficient and the specific run-off is highest in this landscape of the country (Màtra, Börzsöny, Zemplèn mountains). On the limestone plateaus (Bükk Mountains, Aggtelek Karst) infiltration is considerable. The infiltrated waters are discharged in the karst springs of the foothills. In the landscape there are excellent possibilities for the erection of storage dams. Thus, not only the water-supply problems of the industrial settlements and towns, but those of irrigation for agriculture could be solved. Mineral and medicinal water resources also are rich. Especially in the marginal areas there are great possibilities for tapping thermal waters by bore-wells. These still are unexploited reserves for potential development of balneological centers, and intensive green houses.

In the Inner Carpathian Volcanic Mountains the brown forest soils and grey brown podzolic soils dominate, while on the carbonate surfaces. rendzina soils are common. In the most humid areas the podzolic brown forest soils also occur, due to the stronger leaching. The high relative relief and bedrock conditions, as well as the sudden precipitation in large quantities, which are especially frequent in summer, are factors threatening to increase the erosion hazards. Erosion has been steadily increasing during 


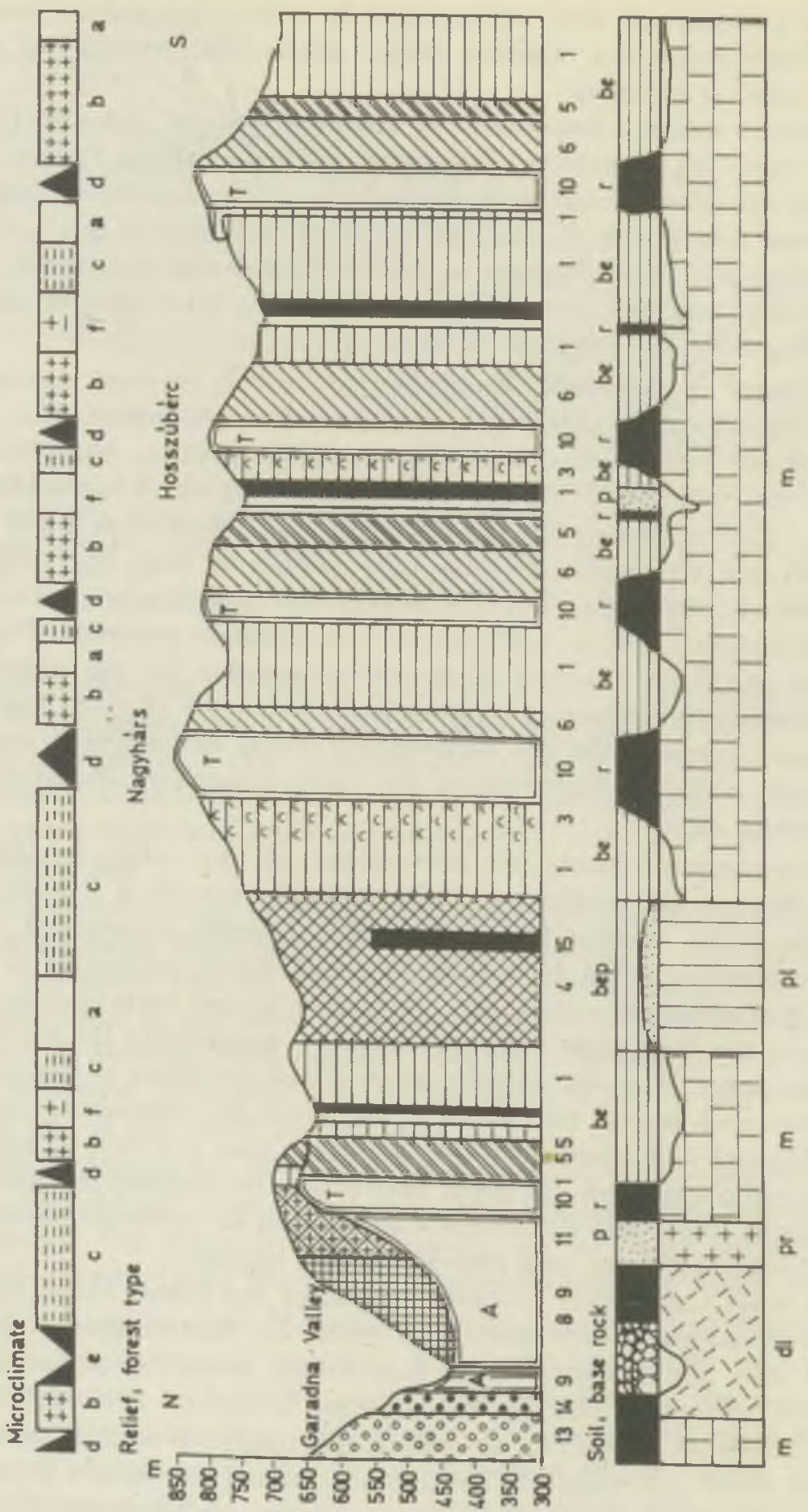


the course of the large scale shrinkage of forests, expansion of the industrial and urban areas, and other landscape transformations.

Forests still predominate in natural vegetation, although they are being continuously reduced. In accordance with the elevational zonation the oak, hornbeam-oak and beech woods constitute the zonal vegetation (Figure 27). A zone of coniferous forests is absent even at the highest levels. In the vegetation, similarly to the case of soils, the rough morphology and the resulting peculiar meso- and microclimate conditions have produced numerous intra- and extrazonal plant associations. Of these the thermophilous oakwoods and karst-shrub forests are significant. In the marginal areas of the territory where this vegetation has been cleared, famous vineyards flourish. The rocky, ash-linden woods of the higher mountains are excellent habitat for game, still abounding in species including elk, deer and mountain gam and wild-boar.

The macro-region of the North Hungarian Mountains is composed of uniform ecological landscape types. It is the low mountain types of rather extreme (subcontinental) climate that are predominant. Most common are the volcanic areas with grey brown podzolic soils, covered by zonal Turkeyoak and hornbeam-oak forests (Visegrád, Börzsöny, Mátra 〈Figure 28). Cserhát and Zemplén mountains). These landscapes are more dissected than the type of carbonate rock types, covered mainly by rendzina and brown forest soils, which predominate in the lower levels of the Bükk Mountains and Aggtelek Karst (Figure 29). The types of the highlands of Middle European climate and of beech-forests, occupy only minor patches. The highest parts of the volcanic High-Börzsöny. Central Mátra and Zemplén mountains are of rough morphology, while the Bükk Plateau is poorly dissected and covered by rendzina soils.

Fig. 27. Complex forest type translet from the beech forest zone of the Bükk-Plateau (Demonstration of the unity of the plant cover and environment) (after B. Zolyomi - P. Jakues - Z. Baráth - A. Horánszky, 1954). Relief: 2,5 times distorted in height. - I. Microclimate types: $a=$ undistinctive type (plateau); $b=$ warm slope type of highgrade isolation; $c=\mathrm{cool}$ slope type of low-grade isolation; $d=$ peak type: $e=$ walley type: $f=$ extreme, frost-hole, sink hole-type. II. Forest types: 1 = Asperula beech forest type: 3 = Mercurialis-Aegopodium beech forest type; $4=$ Oxalis beech forest type: $5=$ Carex pilosa beech forest type; $6=$ Melica beech forest type; $8=$ rocky beech forest type: $9=$ ravine forest; $10=$ ash-linden forest; $11=$ calciphobic beech forest; 13 = calciphilous oak farest; $14=$ pubescent oak shrub forest; $15=$ planter spruce forest; meadows remained empty. III. Soil types: bep = podzolizing variety of brown forest soil; $p=$ podzol (primary and secondary); $r=$ rendzina. At the bottom of the Garadna Valley alluvial sceleton soil. The soil of a deeper layer is marked by a deepening into the base rock. IV. Base rock: $m=$ light, laminated Triassic limestone; $d$ l $=$ Gutterstein dolomite; $\mathrm{pl}=$ silky greenish grey clay slate; $\mathrm{pr}=$ quartz porphyry and porphyroid; $s m=$ dark grey Permian limestone 


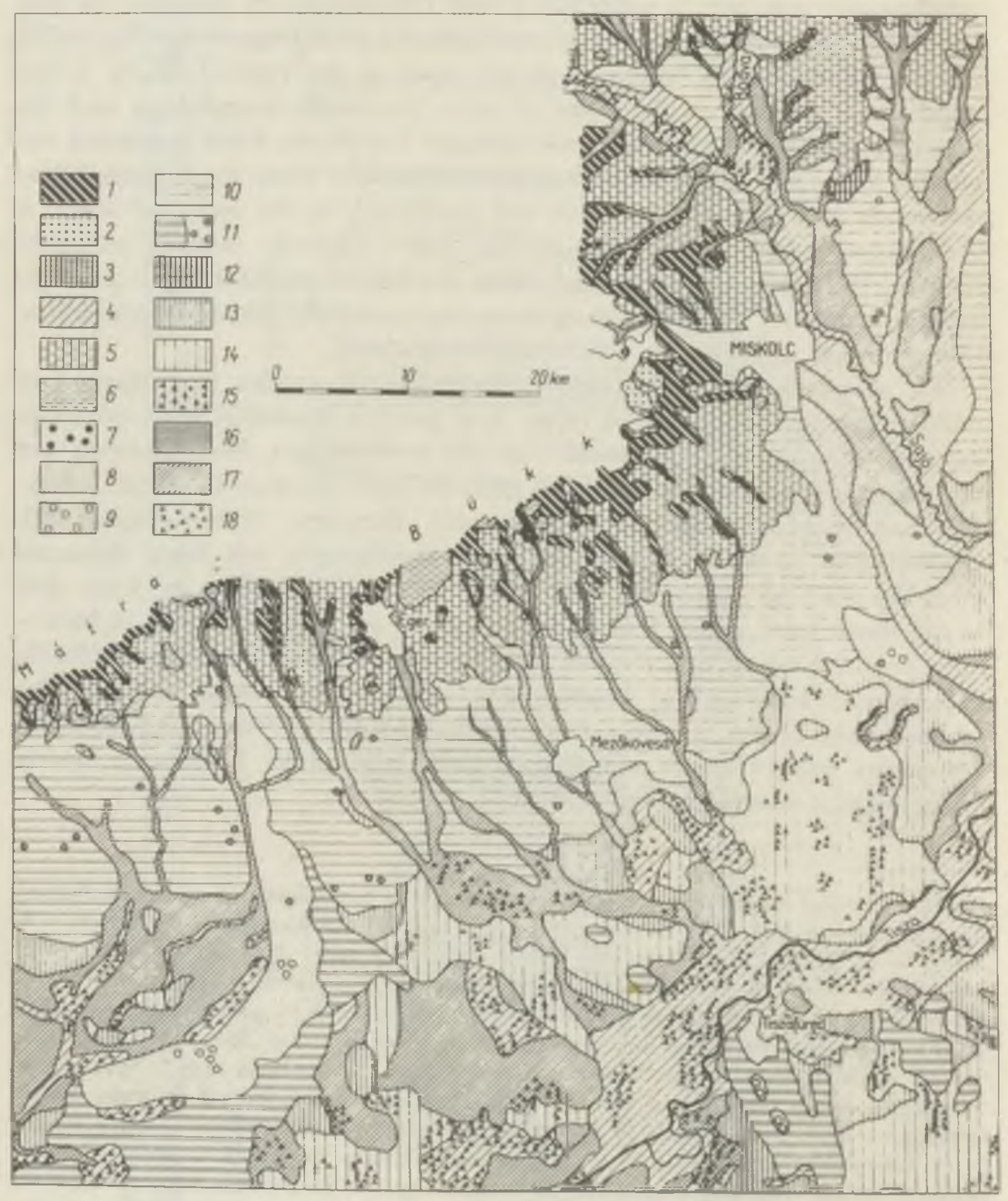


Fig. 28. Vegetation Map of the contact zone of the Great Plain and the Hungarian Mountains. Detail from the vegetation map of Hungary, 1:200 000. Edited by P. Jakucs (P. Jakucs: Bükk, Cserehát; M. Kovács: Mátra; B. Zólyomi: The Great Hungarian Plain). - 1 = montane hornbeam-oak forest; 2 = beech forest on acidic soil; $3=$ oak forest onacidic soil; $4=$ grove forests in the flood plains with Salix and Populus; $5=$ forests with Quercus cerris and Quercus petraea; $6=$ forests with Quercus pubescens and shrub forests: $7=$ rock-lawns, slope with steppe-type grass vegetation: $8=$ oak woods on sandy ground; $9=$ sandy steppe; $10=$ oak woods with tortar maple; $11=$ loess steppe and shrub; $12=$ oak woods with Acer campestre; 13 = tortar maple oak woods on alkali soil: $14=$ solonetz vegetation; $15=$ swamps on alkali soil; $16=$ submontaine Alnus-forests; $17=$ grove forests in the flood plains with Fraxinus, Ulmus and Quercus: 18 = aquatic vegetation, swamps
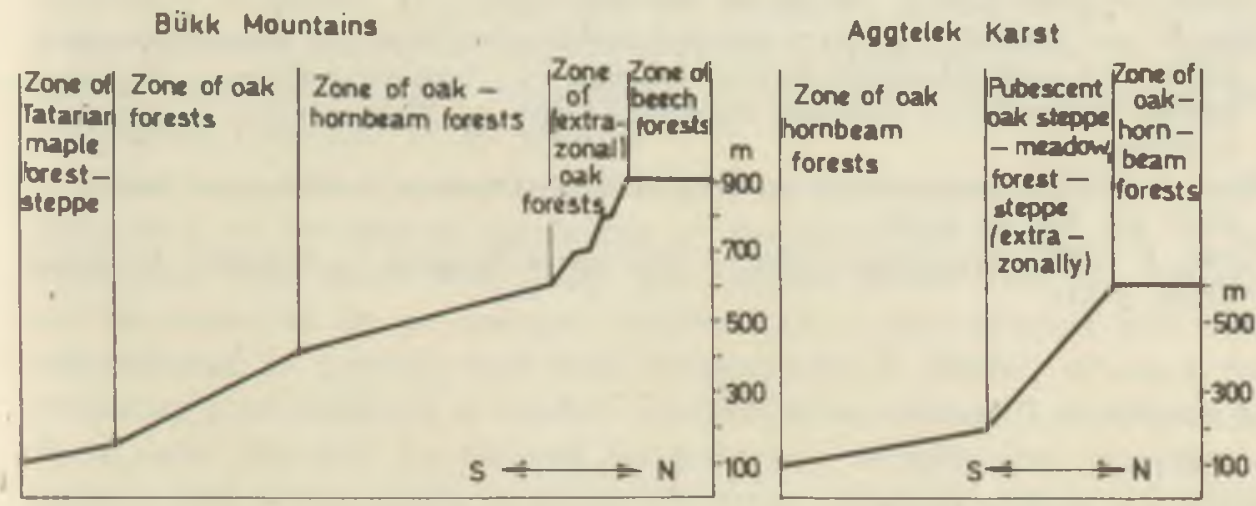

Fig. 29. Forest zones of the southern slopes in the Bükk Mountains and the Aggtelek Karst (schematic profile after P. Jakucs, 1954). This figure clearly demonstrates the regularity that on steep, extremely warm slopes (but similary on cool ones, too) always plant communities of a zone lying by one or two zones lower can be found in extrazonal development

\section{BIBLIOGRAPHY}

Adám, L., Marosi, S. and Szilárd, J. (1959). A Mezōföld természeti földrajza (Physical geography of the Mezốfóld). - Budapest: Akadèmiai Kiadó, p 514. (Fôldrajzi mo. nográfiák 2.)

Bernàth, T. ed. (1969). Magyarország gazdaságföldrajza (Economic geography of Hungary). - Budapest: Tankönyvkiadó, p 546.

Borsy, Z. (1961). A Nyirség természeti foldrajza (Physical geography of the Nyirség). Budapest: Akadémiai Kiadó, p 227. (Földrajzi monogrófiák 5.)

Bulla, B. (1962). Magyarország természeti földrajza (Physical geography of Hungary). Budapest: Tankönyvkiadó, p 423.

Bulla, B. (1962). Magyarország természeti tájai (Physical regions of Hungary). - Földr. Közl. 1, Vol. 10, pp 1-16. 
Láng, S. (1960). Magyararszág tájtérképe. Magyarország éghajlati atlasza, 8. térkép (Land map of Hungary. Climatic atlas of Hungary, 8th map). - Budapest: Akademiai Kiadó.

Magyarország Éghajlati Atlasza (Climatic Atlas of Hungary) Vol. 1 (1960), Vol. 2 (1967). Kakas, J. ed. - Budapest: Akadêmiai Kiodó.

Magyarország Vizfoldtani Atlasza (Hydrogeological Allas of Hungary). Schmidt, E. R. ed. - Budapest: MAFI. p (1958).

National Atlas of Hungary. - Budapest: "Cartographia". p 112. (1967).

Pècsi, M. (1964). Ten years of physicogeographic research in Hungary. - Budapest: Akadémiai Kiadó, p 132. (Studies in geography 1.)

Pécsi, M. (1970). Geomorphological regions of Hungary. - Budapest: Akadémiai Kiadó, p 45. (Studies in geography in Hungary 6.)

Pécsi, M. and Sáfalvi, B. (1964). The geography of Hungary. - Budapest: Corvina. p 300. Pécsi, M. and Somogyi, S. (1967). Magyarország természeti földrajzi tájai es geomorfológiai körzetei (The physiographic landscapes and geomorphological regions of Hungary). - Foldr. Közl. 4, Vol. 15, pp 285-304.

Pécsi, M. and Somogyi, S. (1969). Subdivision and classification of the physiographic landscapes and geomorphological regions of Hungary. - Research problems in Hungarian applied geography. - Budapest: Akadémiai Kiadó, pp 7-24. (Studies in geography in Hungary 5.)

Ronai, A. (1956). A magyar medencék talajvize (Ground water of the Hungarian basins). MAFI évk. Vol. 46, p 245.

Vadász, E. (1960). Magyarország földtana (Geology of Hungary). - Budapest: Akadémiai Kiadó, p 645. 


\section{THE CLIMATE OF HUNGARY}

N. BACSO

The climate of Hungary, due to the location of the country between the geographical latitudes 46 to $49^{\circ} \mathrm{N}$, is a moderate one. This character is further enhanced by Hungary's location at the westward-narrowing onefifth of the Eurasian continent in relative proximity to the important water masses of the Atlantic Ocean and the Mediterranean. This location causes a predominance of maritime winds (Figure 1) as compared to continental air transport, and has a moderating influence on extreme temperature conditions. However, the orography of Hungary's surroundings with the great mountain masses of the Alps and the Carpathians forms an almost closed basin, which by a modification of wind conditions, enhances the continental character of its climate.

These three factors exert their influence on the weather of this country (according to the actual conditions of European air circulation) in an alternating and mixed way. Thus, the westerly winds from the Atlantic are accompanied by an overcast weather rich in precipitation with cool temperatures in summer and mild temperatures in winter; whereas the temporary predominance of eastern, continental air masses is accompanied by a clear sky and by extreme temperatures, bringing hot weather in summer and severe colds in winter. At times recurring violent intrusione winds of arctic origin causes strong reductions of temperature. Finally, as a consequence of air transport from Mediterranean, arid hot weather in summer and mild, cloudy, rainy weather in the autumn and the winter occurs.

When one of the four climatic types is prevailing it usually lasts for a rather short time, that is, for only a few days, and therefore none of these types is capable of fully exerting its influence. When, however, one of them prevails during several weeks or even months or during a whole season. Hungary experiences protracted periods of weather which corresponds to the climates of such cities as London, Helsinki, Kiev or Napoli. This fact explains the peculiar fact that in Hungary, though the average values of climatical elements are expressely moderate, the extreme values which occur rarely are very important. Thus, the very severe winters and hot summers are anomalies, but in every season there is a possibility for droughts, and there are summers and winters with a surplus of precipitations. Of course, these conditions are rare, but important and protracted climatic events can create a severe situation for agricultural production 


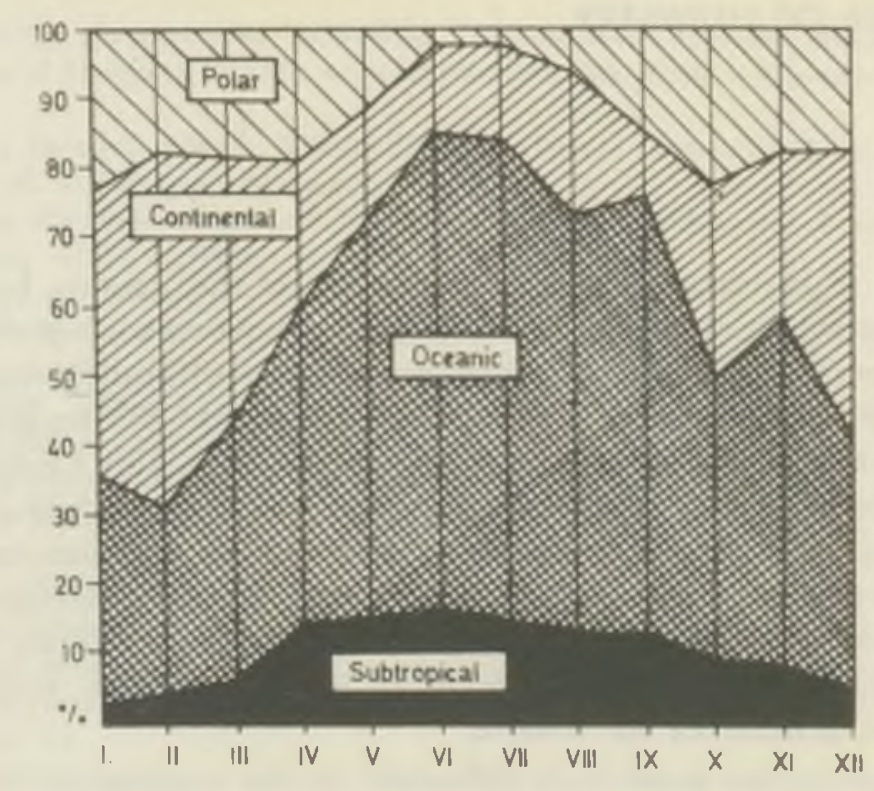

Fig. 1. Residence times of air masses of different origin in Budapest (average for a great number of years)

in this country, mainly for the production of plants which are most sensitive toward extreme climatic occurences.

All the phenomena of weather and climate are produced by the very sophisticated processes of exchange of matter and energy occuring in the lower layers of the atmosphere. These processes determine the influence of radiation (solar radiation and terrestrial radiation emission) and air transport. In the latter case, the humidity content of the air also is of a great importance. The sophisticated combination and actual interaction of these factors of energy and material transport and their seasonal variations determine the characteristic daily and annual variations of the climatic elements, as well as their geographic distributions.

\section{SOLAR RADIATION}

The fundamental influence of radiation on Hungary's climate is the balance of irradiation and radiation emission, a factor that in various years may exhibit a different behaviour as a consequence of the modifying influence of atmospheric circulation. According to data shown in Table 1 and in Figure 2, the average radiation balance of the earth's surface in this country is a positive one and the annual sum is rather important. 
Table 1.

ANNUAL VARIATION AND ANNUAL SUM OF RADIATIVE ENERGY in HUNGARY (kilocal/ $\mathrm{cm}^{2}$ ), 50 YEAR AVERAGE

$\begin{array}{rrrrrrrrrrrrrr} & I & I I & I I I & I V & V & \text { VI } & \text { VII } & \text { VIII } & \text { IX } & \text { X } & \text { XI } & \text { XII } & \text { Year } \\ \text { 1. } & 9,8 & 11,5 & 18,3 & 23,7 & 29,4 & 30,5 & 30,4 & 26,5 & 20,3 & 15,0 & 9,7 & 7,7 & 231,8 \\ \text { 2. } & 3,6 & 4,1 & 6,6 & 8,7 & 10,0 & 10,4 & 9,4 & 7,9 & 6,5 & 5,0 & 3,8 & 3,3 & 79,9 \\ \text { 3. } & 2,1 & 2,2 & 3,8 & 4,5 & 5,2 & 5,1 & 4,9 & 4,6 & 4,4 & 4,0 & 2,9 & 2,4 & 46,1 \\ \text { 4. } & 3,1 & 4,8 & 7,9 & 104 & 14,2 & 15,0 & 16,1 & 14,0 & 9,4 & 5,9 & 3,0 & 1,9 & 105,7 \\ 5 . & 1,3 & 1,7 & 1,2 & 1,8 & 2,4 & 2,7 & 2,4 & 2,1 & 1,5 & 0,8 & 0,4 & 0,4 & 18,7 \\ 6 & 19,4 & 18,0 & 21,5 & 22,4 & 24,9 & 25,7 & 26,9 & 26,4 & 24,0 & 23,0 & 20,6 & 20,0 & 272,8 \\ 7 . & 16,6 & 14,8 & 17,7 & 18,2 & 20,4 & 21,5 & 22,7 & 22,0 & 19,4 & 19,2 & 17,8 & 17,7 & 228,0 \\ \text { 8. } & 2,8 & 3,2 & 3,8 & 4,2 & 4,5 & 4,2 & 4,2 & 4,4 & 4,6 & 3,8 & 2,8 & 2,3 & 44,8 \\ 9 . & -1,0 & -0,1 & 2,9 & 4,4 & 7,3 & 8,1 & 9,5 & 7,5 & 3,3 & 1,3 & -0,2 & -0,8 & 42,2 \\ 10 . & 59 & 84 & 136 & 186 & 254 & 271 & 296 & 270 & 193 & 135 & 68 & 39 & 1991\end{array}$

1. Extraterrestrial radiation over Hungary

2. Scattered reflection

3. Atmospheric absorption

4. Global irradiation reaching the surface

5. Reflection from the earth's surface

6. Total emission from the earth's surface

7. Radiation received from atmospherical emission

8. Effective emission

9. Radiation balance

10. Duration of insolation in hours

The data in Table 1 are considered to be average values for the whole of the country. They indicate that Hungary is rich in solar radiation and that the duration of insolation is plentiful. Although the insolation period is higher in Hungary than in most countries of Western Europe (with the exception of Spain and the southern parts of France), both the amount of irradiated energy and the duration of irradiation is lower in this country than in Italy or in the Balkans. The end result of all the radiation processes is represented in line 9 of Table 1 by the radiation balance data. These data show the amount of solar radiation energy which is produced in the long run, together with the influence of the general circulation. For eight months of the year the radiation balance is positive, however, from November to February it is a negative value. In this period there is a loss of previously accumulated energy. In the period from March to October, however, there is a surplus of energy, which is sufficient in the spring for melting the snow $(0,5 \mathrm{kcal})$ and during the whole year for meeting the heat requirements of evaporation $(30 \mathrm{kcal})$. It also is sufficient $(11,5 \mathrm{kcal})$ to warm up rapidly the lower atmosphere trough turbulent exchange and as a result the cold winter temperatures are replaced by warm summer values. The table also clearly shows the important annual variation in the radiation values which 


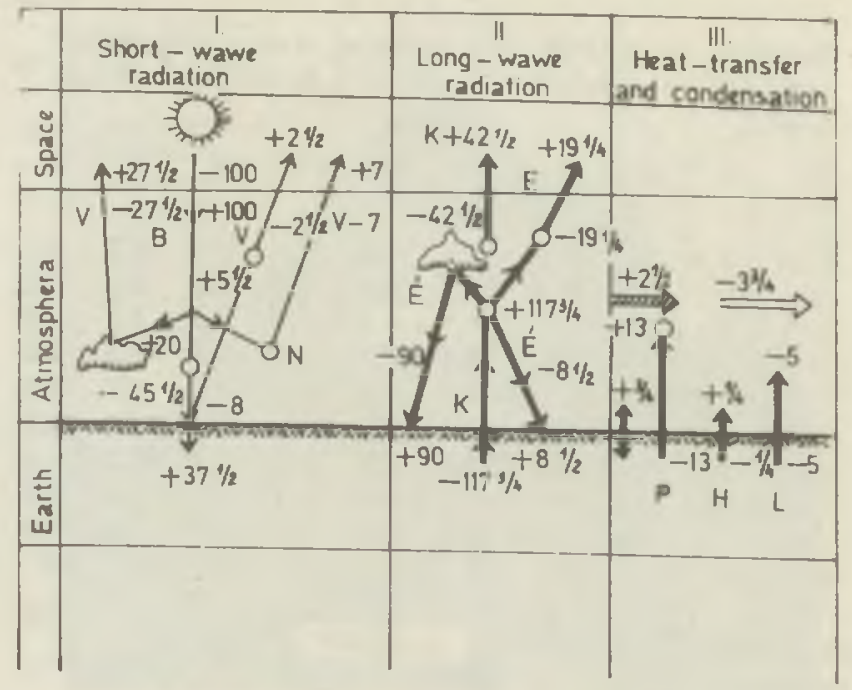

Fig. 2. Energy balance of radiation for the air space of Hungary. $-V=$ reflection; $\mathrm{B}=$ irradiation; $\mathrm{K}=$ outgoing radiation; $\mathrm{N}=$ absorption; $\mathrm{O}, \hat{\mathrm{E}}=$ radiation emitted from the sky and from clouds; $P=$ evaporation: $H=$ heat exchange of the soil: $\mathrm{L}=$ turbulent exchange of heat

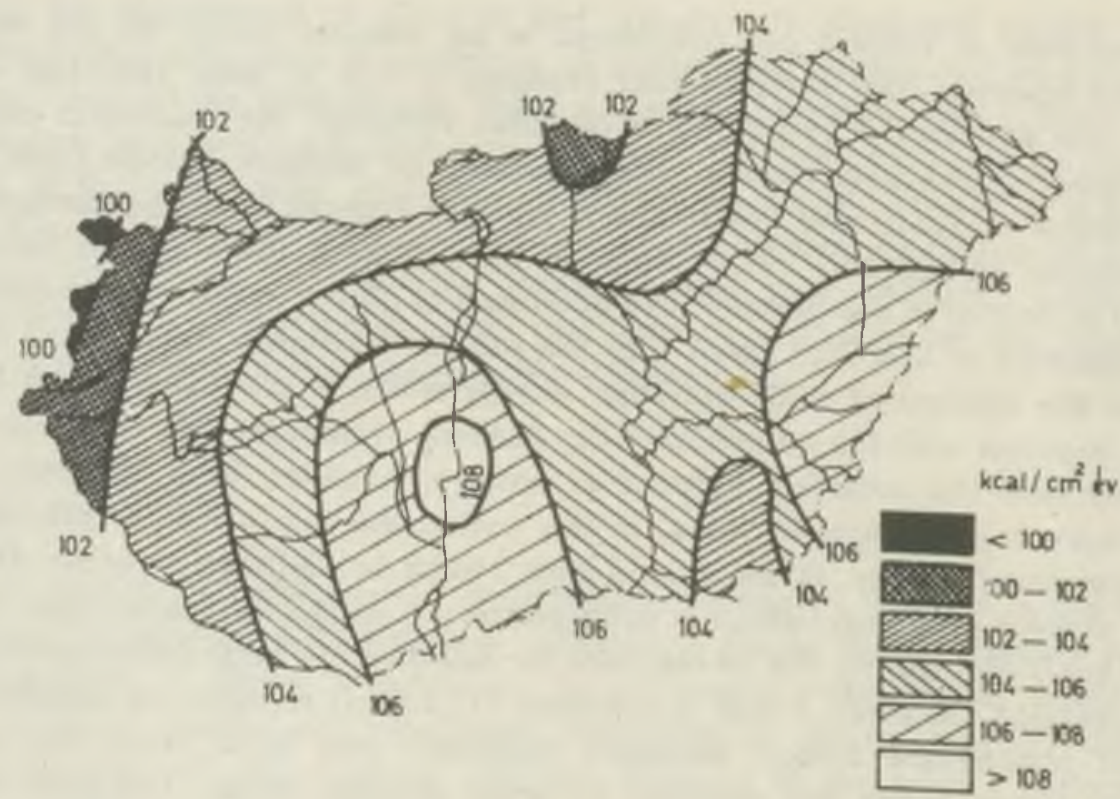

Fig. 3. Annual sums of global irradiation (50-year averages) 


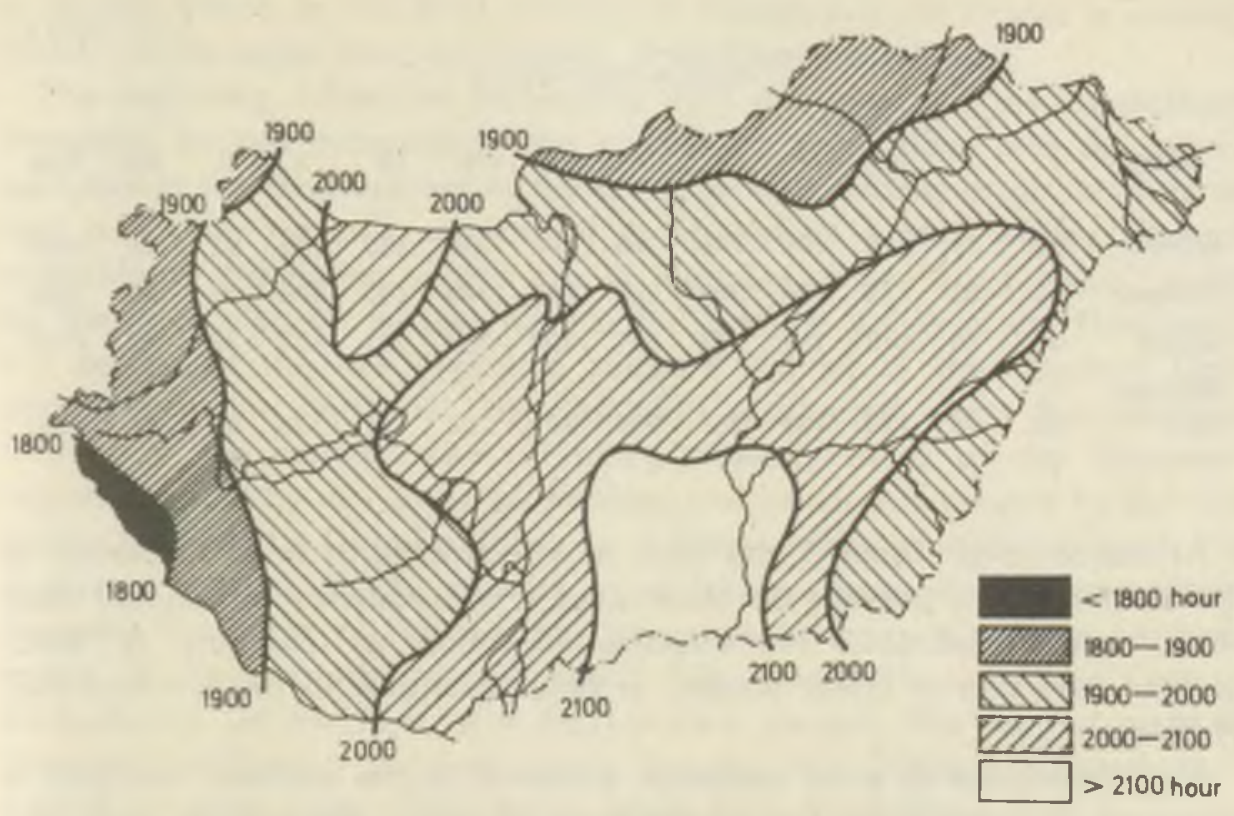

Fig. 4. Annual sums of insolation hours (50-year averages)

corresponds to the life-cycles of plants. The periods of negative radiation balance correspond to the winter rest in plant life.

Global irradiation (the sum of direct solar radiation and sky radiation) is not identical for the whole area of the country. The geographical distribution is shown in Figure 3. The regional variations are within the limits of +3 and -7 percent. The greater part of solar energy reaches the terrestrial surface during the growing season (from April to September), with 1500 hours of insolation during the summer half-year, while in the other half-year, there is only about 500 hours. Duration of insolation also varies in the different districts. From Figure 4 it is obvious that most insolation is experienced in the central counties of the southern part of the country. while the lowest values are found along the western frontier, at the foothills of the Alps.

Monthly and annual sums of insolation hours for several stations throughout the country are given in Table 2.

The low nebulosity of the Great Plain is a consequence of the location of this area within a basin. It is closed from the western through the southeastern sides and winds mainly can penetrate only with a descending flow which dissipates the clouds. Thus, nebulosity is lower in the plains than in the mountainous regions of moderate height where the ascension of inner winds provides more occasions for the formation of clouds. 
Table 2

INSOLATION HOURS

\begin{tabular}{|c|c|c|c|c|c|c|c|c|c|c|c|c|c|}
\hline Station & 1 & 11 & 111 & IV & v & VI & VII & VIII & IX & $x$ & $x \mid$ & XII & Year \\
\hline opron & 59 & 81 & 140 & 181 & 246 & 256 & 266 & 255 & 182 & 116 & 62 & 44 & 188 \\
\hline Budapest & 59 & 83 & 136 & 186 & 252 & 269 & 297 & 270 & 195 & 134 & 67 & 40 & 10 \\
\hline zzeged & 64 & 90 & 143 & 187 & 258 & 271 & 309 & 286 & 211 & 152 & 79 & 52 & 210 \\
\hline $\begin{array}{l}\text { yiregy- } \\
\text { aza }\end{array}$ & 62 & 75 & 139 & 189 & 251 & 259 & 281 & 262 & 191 & 138 & 67 & 46 & \\
\hline
\end{tabular}

As indicated by Table 3, the ratio of effective duration of insolation to the astronomically possible duration is, as a consequence of frequent clear skies, rather favourable. The effective insolation of Hungary is much greater than that of Great Britain, or other countries in the northern half of Europe.

The abundance of solar radiation primarily in the summer half-year is extremely favourable for the development of crops, particularly fruit, and wine production. Thus, the quality flavour, colour, and vitamin contents of the fruit and wine products generally are excellent, and they are much in demand for export to the whole area of Western and Northern Europe. The same circumstance ensures that selected varieties of rice, which is an indigeneous plant in the southern countries of Hungary, produce satisfactory yields and are economical crop on the Alföld.

Table 3

EFFECTIVE INSOLATION at BUDAPEST

(percents of the astronomically possible values)

$\begin{array}{lllllllllllll}\text { I } & I I & I I I & \text { IV } & V & \text { VI } & \text { VII } & \text { VIII } & \text { IX } & X & \text { XI } & \text { XII } & \text { Year } \\ 21 & 29 & 37 & 45 & 54 & 56 & 62 & 61 & 52 & 40 & 24 & 15 & 45\end{array}$

AIR CURRENTS

Although solar radiation provides the greatest part of the energy used in weather phenomena, the other source of atmospheric energy - the flow of air - cannot be omitted in a discussion of climate. In many cases its influences indeed do not increase the energy content, but instead result in a decrease. It not only has a warming effect but frequently it also produces 
a cooling effect. In the final analysis in Hungary it constitutes a cooling factor. At the same time, air currents determine precipitation.

The modifying influences emanating from the Alps and the Carpathian Mountain Ranges surrounding this country on three sides play an important role in the development of the direction and velocity of air currents as well as in the westerly currents of the European branch of the general atmospheric circulation. There are in Hungary three "wind doors" open for the advancing air masses. One is the Danube Valley in the' Northwest, the second is the low mountain range $(1000 \mathrm{~m})$ of the "Eastern Carpathians" in the northeast, and the third is situated along the southern frontier of the country. The prevailing westerly winds of the European region are split by the range of the Alps and reach this country by the two paths: through the Danube Valley as a northwesterly wind and through the southwest frontier of the country as a southwesterly wind. It sometimes happens that part of the westerly air masses turn around the northern range of the Carpathians and reach this country through the "Eastern Carpathians" in the form of a northeastern current. The natural path of Eurasian continental currents leads through the "Eastern Carpathians" toward the inner parts of the basin. While from the Balkans Mediterranean or African air masses reach Hungary. The big intrusions of polar air masses originate partly from the northwest and partly from the north in spite of the presence of a high mountain range.

The thermal characteristics of air currents from the different quadrants of the compass may be visualized from Figure 5, in which January and July mean temperatures at the locations of origin of the various air masses and at Budapest are illustrated.

Prevailing wind directions, derived from statistics for a great number of years, are given for the different districts of this country in Figure 6. The essence of the flow pattern is that in most places the northerly (that is NW, $N$ and NE) currents are responsible for the predominantly southern direction of the air transport in this country: Thus, the western and central parts of the country obtain air currents mainly from the NW and the N. From spring to autumn these currents are cooler than the air found in this country, and in the winter, they are milder if they originate from the moderate Atlantic regions. In the eastern half of the Alfold, that is, the region beyond the river Tisza, mostly northeastern and eastern winds prevail. Air masses originating in the interior of the Eurasian continent and arriving through the .Eastern Carpathians" in winter and other seasons as well are colder, or at least cooler, than the air of the basin. Accordingly the overwhelming majority of these prevailing winds, (among which can be found heavy storms) produce a cooling effect, that is, they must be regarded as energyconsuming factors, because they take in energy over 


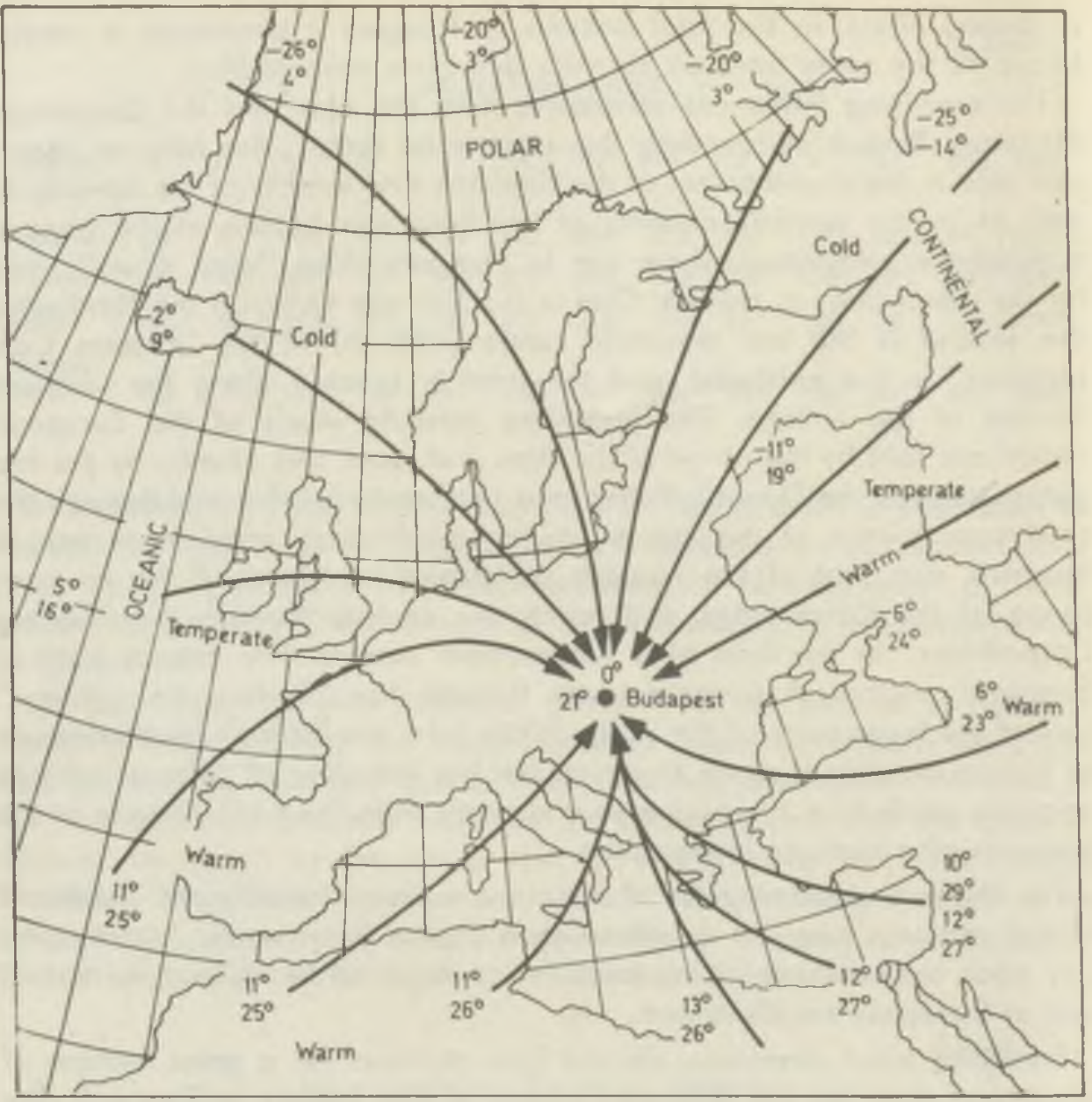

Fig. 5. Temperature conditions of air masses of different origin arriving in Hungary

the area of this country and they are warmer when they leave the frontiers in the south. The amount of displaced energy is equal to $8,5 \mathrm{kcal} \mathrm{cm}^{2}$ year.

Arriving air masses of a maritime origin import amounts of water vapour greater than the amounts contained in the Eurasian air masses. The important latent energy contained in these air masses (estimated at 6 $\mathrm{kcal} / \mathrm{cm}^{2}$ year) leads to a gain in energy when it is liberated at cloud level during the formation of clouds. The difference between these two items, amounting to $2,5 \mathrm{kcal} / \mathrm{cm}^{2}$ year, represents the loss of energy in the air. A consequence of this situation is that the radiation balance of the country must be a positive one, as the loss of energy caused by atmospheric circulation leads to a reduction in the emitted radiant energy. 


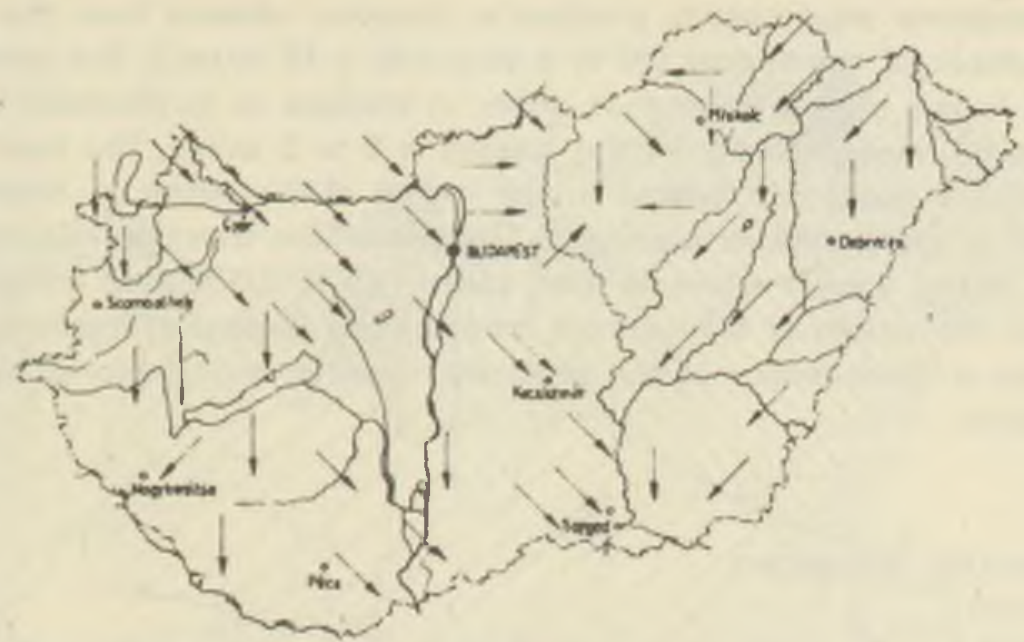

fig. 6. Directions of prevalling winds (50-years averages)

The seasonal frequencies of wind direction at Budapest are given in Table 4.

These data indicate that prevailing northerly winds predominate and produce the cooling effect of air currents in this country. In the summer the frequency of NW and $\mathrm{N}$ winds is higher (European summer monsoon), whereas in winter the NE winds are more frequent. From the data on calm conditions it appears, that in the autumn there is high frequency of the periods of "St. Martin's summer", characterized by calm, quiet, protracted spells of clear weather. The frequency of the prevailing winds is equal to 25 to 35 percent.

Table 4.

FREQUENCIES OF WIND DIRECTIONS at BUDAPEST,

50 - yeal averages

$\begin{array}{lrrrrrrrrr} & \text { N } & \text { NE } & \text { E } & \text { SE } & \text { S } & \text { SW } & \text { W } & \text { NW } & \text { C } \\ & & & & & & & & & \\ \text { Winter } & 12 & 9 & 5 & 8 & 7 & 6 & 9 & 25 & 19 \\ \text { Spring } & 10 & 8 & 5 & 9 & 8 & 7 & 10 & 24 & 19 \\ \text { Summer } & 10 & 6 & 3 & 5 & 5 & 6 & 13 & 33 & 19 \\ \text { Autumn } & 9 & 8 & 5 & 8 & 6 & 6 & 10 & 22 & 26 \\ \text { Year } & 10 & 8 & 5 & 8 & 7 & 6 & 10 & 25 & 21\end{array}$

The common wind speeds of Hungary are rather moderate in comparison to those of other European countries. This is an obvious consequence of the protection against winds provided by the Alps and the Carpathians. 
The moderate wind speeds produce a situation obvious from the rather low number of stormydays (60 in a year with $v 15 \mathrm{~m} / \mathrm{sec}$.). The number of storms in this area is lower than either in Western or in Northern Europe. The annual mean velocity for the country is 2 to $3 \mathrm{~m} / \mathrm{sec}$. The most windy area of the country is located in the region of the inflow of Atlantic air masses in the northwest along the Danube where average velocities are 3 to $4 \mathrm{~m} / \mathrm{sec}$. Lowest values of wind speed (1,5 to $2,0 \mathrm{~m} / \mathrm{sec}$.) are encountered in the vicinity of the northern mountainous regions of medium height and are a consequence of the protection against winds offered by these mountains.

\section{TEMPERATURE CONDITIONS}

In addition to the influences exerted by the two energy-carrying agents namely radiation and air currents - there are two factors which strongly influence the temperature of this country, namely altitude above sea-level and orographical conditions.

On the map of annual mean temperatures shown in Figure 7. the isotherms also exhibit an influence of the geographical latitude, as the southern frontier of the country is on the average 3 degrees centigrade

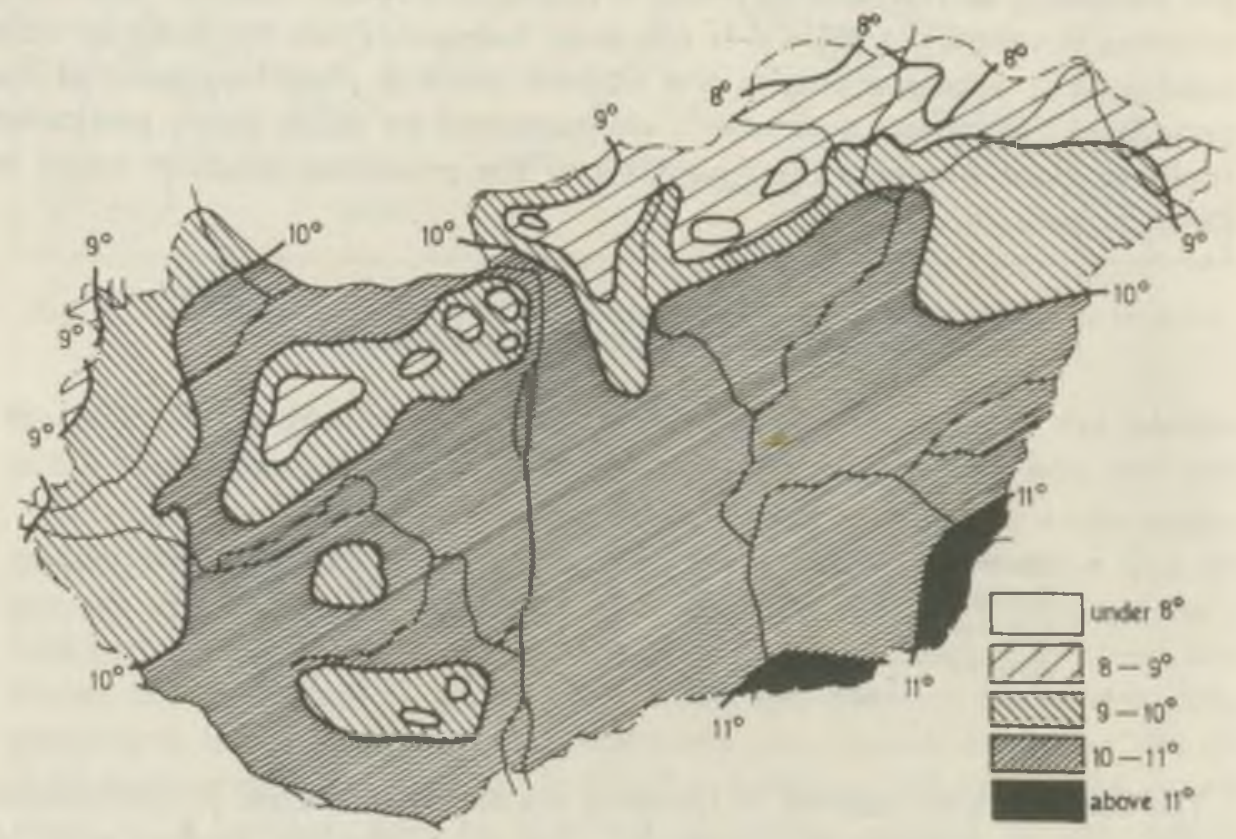

Fig. 7. Annual mean values of air temperature (50-years averages) 


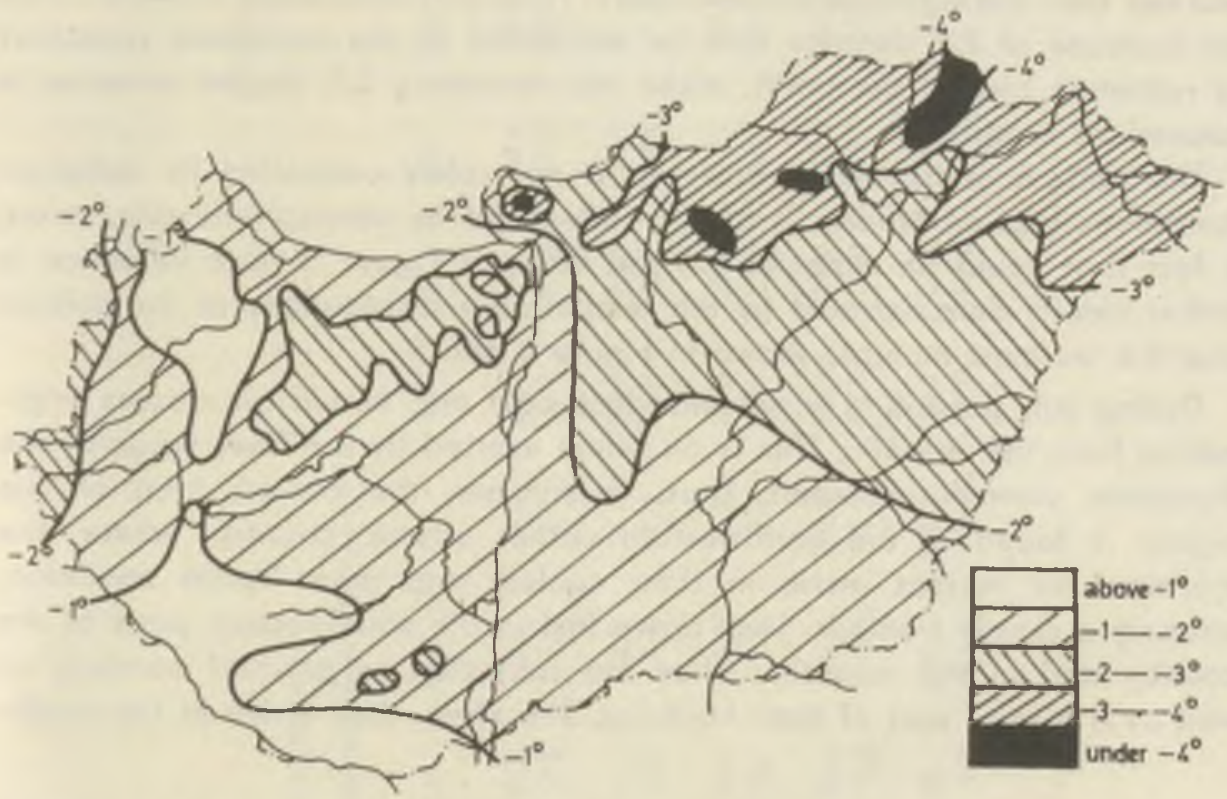

Fig. 8. Mean values of air temperature in January (50-years overages)

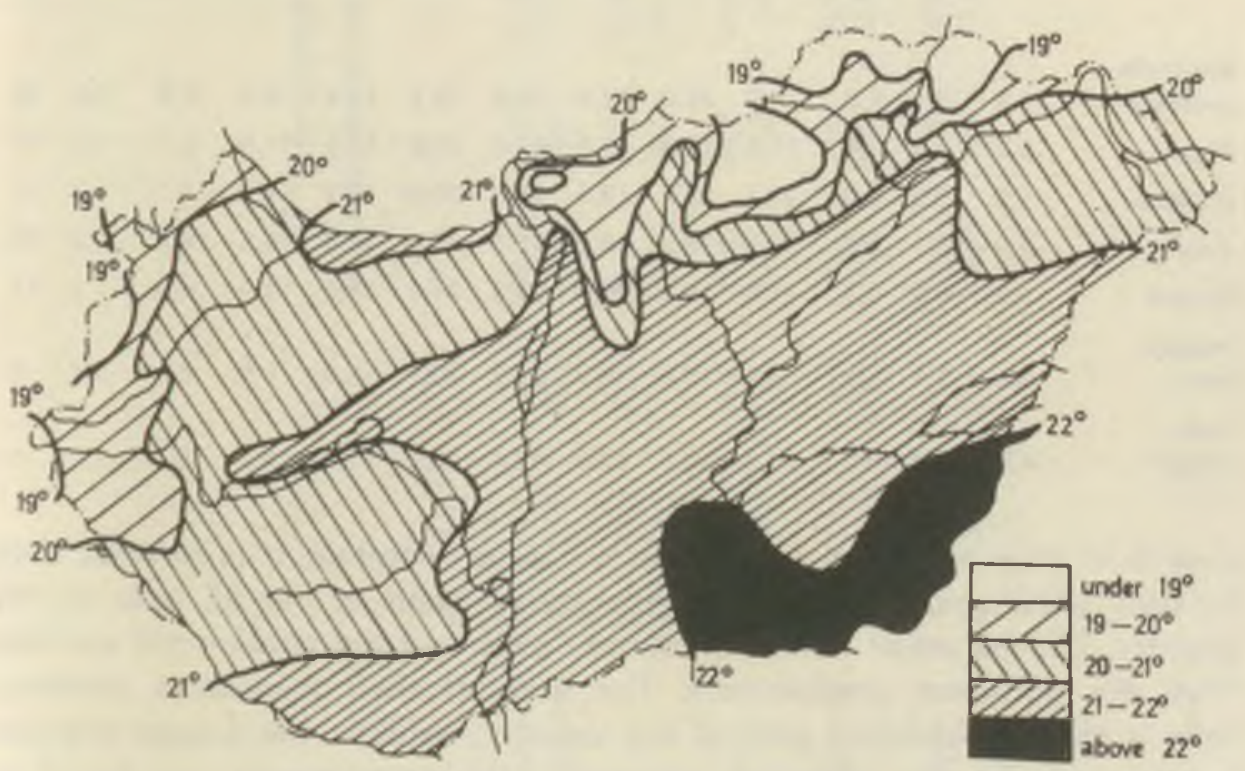

Fig. 9. Mean values of air temperature in July (50-year averages) 
warmer than the northeastern boundary. From this difference, however, only an increase of 2,5 degrees may be attributed to the estimated reduction of radiation toward the north, while the remaining 0,5 degree increase is caused by orography.

The pattern of isotherms, however, is not solely controlled by radiation conditions and orography. It also is influenced by atmospheric circulation, a fact that could be expected on the basis of Figure 5. This influence is rather clearly demonstrated by the temperature distributions of the coldest and the warmest months, shown in Figure 8 and 9.

During July prevailing winds introduce cool and humid air masses originating from the Atlantic. This is an effect exerted by the final stage of the European summer monsoon. Thus, in summer, the coolest area of this region is found in the northwestern corner of the country, where the maritime air masses arrive in their coolest and most humid condition, causing a cloudy weather. They arrive last in the southeastern parts of the country and in the meantime they are subjected to gradual warming as well as a loss of part of their humidity. Therefore, they arrive in the south-

Table 5 .

MONTHLY and ANNUAL AVERAGE TEMPERATURES In CENTIGRADE, 50-YEAR AVERAGES

I II III IV $V$ VI VII VIII IX $\quad x \quad$ XI $\quad$ XII Year

\begin{tabular}{|c|c|c|c|c|c|c|c|c|c|c|c|c|}
\hline $\begin{array}{l}\text { Mosonma- } \\
\text { gyaróvar }\end{array}$ & $-1,6$ & -0.1 & 4,9 & 9.9 & 15,0 & 17,9 & 20,0 & 19.1 & 15.4 & 9.9 & 4,4 & 0.4 \\
\hline Pécs & .0 .7 & 1.0 & 6,4 & 11,4 & 16,4 & 19.8 & 22,0 & 21,5 & 17,4 & 11,5 & 5,7 & 1,6 \\
\hline Budapest & $-1,0$ & 0,9 & 6,0 & 11.1 & 16.4 & 19.5 & 21,5 & 20,8 & 16,7 & 11,0 & 5.1 & 1,3 \\
\hline Kecskemét & $\cdot 2,0$ & -0.1 & 5,3 & 10,7 & 16,2 & 19,3 & 21.5 & 20,6 & 16,3 & 10,6 & 4.6 & 0,2 \\
\hline Szeged & $-1,2$ & 0,6 & 6,3 & 11.4 & 16,8 & 20,0 & 22.3 & 21,4 & 17,5 & 11,9 & 5.9 & 1,4 \\
\hline $\begin{array}{l}\text { Nyiregy- } \\
\text { hâza }\end{array}$ & $-3,0$ & $-1,1$ & 4,5 & 10.1 & 15,8 & 18,7 & 20,7 & 49.7 & 15,6 & 9.9 & 4,1 & $-0,4$ \\
\hline Kékes & 4.0 & -33 & ?? & 47 & 104 & $12 ?$ & 157 & & & G & & \\
\hline
\end{tabular}

east in a drier condition and cause a clearer weather. It is obvious that, in such situations, the highest temperatures occur in the SE area of the country. On the other hand, in January cold and dry continental currents from the northeast predominate. The area of their immediate invasion, that is the northeastern part of the country, exhibits the lowest average temperature. In this situation, relatively mild temperatures are found at the southwestern frontier where the severely cold air masses arrive only 
:

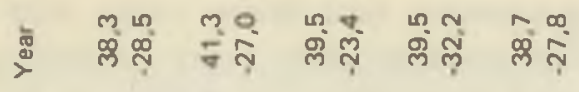

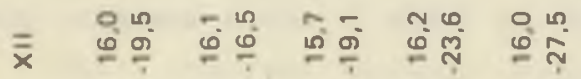

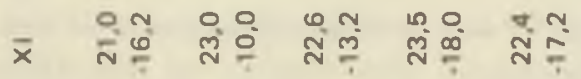

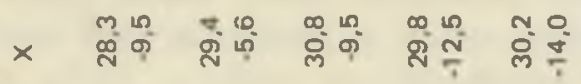

ㄸำ

요

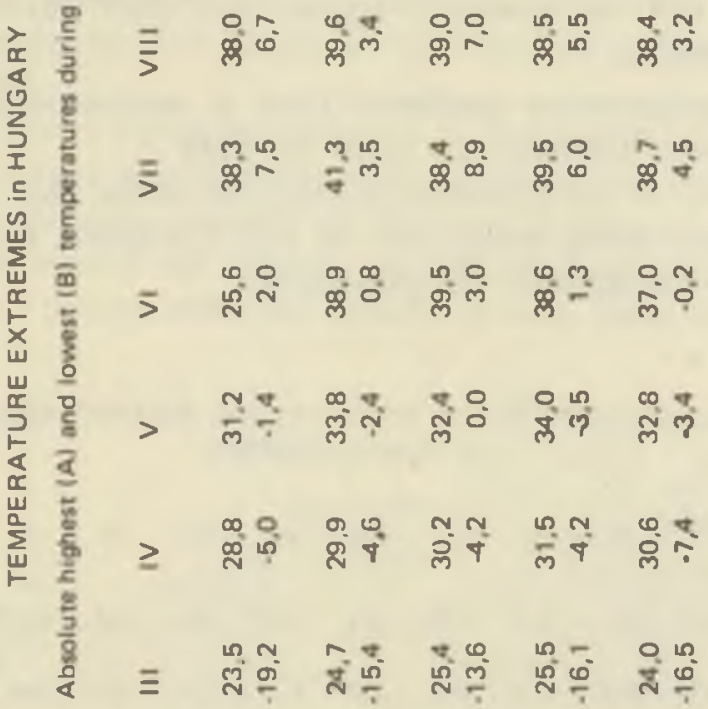

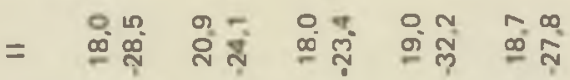

- 華

$\varangle \infty \varangle \infty<\infty<\infty<\infty$

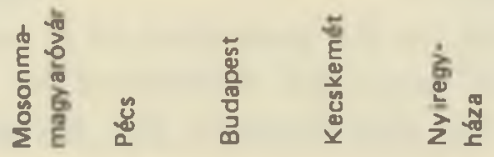


after undergoing warming and where rising mild and humid air masses from the Mediterranean area often occur. Winter is longest and coldest in the northeast and it is shortest and mildest in the southwest. These facts are corroborated by Table 5 which contains average temperatures for Hungary.

The same trends - the early arrival of cool temperatures and the strongest cooling down in the northeastern areas - are also indicated by data of extreme temperatures. The districts of the Alföld, which are the lowest of the basin, also experience rather severe spells (minima at Kecskemét) during some winters mainly in periods of clear weather (Table 6).

The absolute amplitudes are equal to 60 to $70^{\circ}$ centigrade. They are smallest on the higher mountains, and they are equally low along the southern and south-western frontiers. The amplitude of the 50 year averages of extreme temperatures generaly is 50 to $57^{\circ}$. It is lowest on Kékes Peak (altitude $1000 \mathrm{~m}$ ) where it equals only $42,3^{\circ}$ (average max. $26,4^{\circ}$. average $\left.\mathrm{min} .-15,9^{\circ}\right)$.

The vertical temperature gradients (that is, temperature differences for $100 \mathrm{~m}$ difference of altitude) are given in Table 7.

The low values of the gradients during the winter months (the value of $G_{\min }$ in January being equal only to $-0,1^{\circ}$ ) indicate the high frequency of temperature inversions in the mountains.

Table 7.

VERTICAL GRADIENT OF AIR TEMPERATURE, DEGREES CENTIGRADE 50 YEAR AVERAGES

$\begin{array}{cccccccccccccc} & I & I I & I I I & I V & V & V I & V I I & V I I I & I X & X & \text { XI } & \text { XII } & \text { Year } \\ G_{M} & 0,1 & 0,3 & 0,5 & 0,6 & 0,6 & 0,7 & 0,6 & 0,6 & 0,5 & 0,5 & 0,4 & 0,2 & 0,5 \\ G_{\operatorname{Max}} & 0,3 & 0,6 & 0,7 & 0,9 & 0,9 & 1,0 & 0,9 & 0,9 & 0,9 & 0,8 & 0,5 & 0,3 & 0,7 \\ G_{\operatorname{Min}} & 0,1 & 0,0 & 0,4 & 0,3 & 0,3 & 0,3 & 0,3 & 0,3 & 0,2 & 0,2 & 0,3 & 0,1 & 0,2\end{array}$

Temperature conditions also are well characterized by certain frequency values such as the average numbers of frosty days $\left(\mathrm{min} . \leq 0^{\circ}\right)$, of winter days $\left(\max . \geqq 0^{\circ}\right)$, and of severe days ( $\min . \equiv-10^{\circ}$ ) in winter; as well the number of summer days $\left(\max . \geqq 25^{\circ}\right)$, hot days $\left(\max . \geqq 30^{\circ}\right)$ and tropical days $\left(\max . \geqq 35^{\circ}\right.$ ) in the summer. Their average values for some stations are given in Table 8 .

The possibilities for the production of a number of valuable agricultural and horticultural crops are determined by the length of the frost-free period during the year because this period is the actual, undisturbed 
Table 8.

NUMBER of DAYS with EXTREME TEMPERATURES 50 YEAR AVERAGES

Pècs Magyaróvâr Kecskemét Nyiregyhãza

$\begin{array}{lrrrr}\operatorname{Min} \leqq 0^{\circ} & 78 & 95 & 91 & 109 \\ \operatorname{Max} \leqq 0^{\circ} & 23 & 29 & 31 & 33 \\ \operatorname{Min} \leqq-10^{\circ} & 8 & 12 & 13 & 17 \\ \operatorname{Max} 25^{\circ} & 79 & 62 & 82 & 78 \\ \operatorname{Max} \geqq 30^{\circ} & 23 & 12 & 23 & 21 \\ \operatorname{Max} 335^{\circ} & 2 & 0 & 1 & 0\end{array}$

growing season of the plant, during which an abundant crop of good quality may be produced. The length of the frost-free period in Hungary is shown in Figure 10.

The annual variation of air temperature is represented in Figure 11. by 80 -year average values of the daily mean temperatures in Budapest. The coldest period of the year consists of the last 10 days of January, when dry and cold continental air masses usually predominate. The warmest period of the year occurs after the middle of July. Both extreme periods

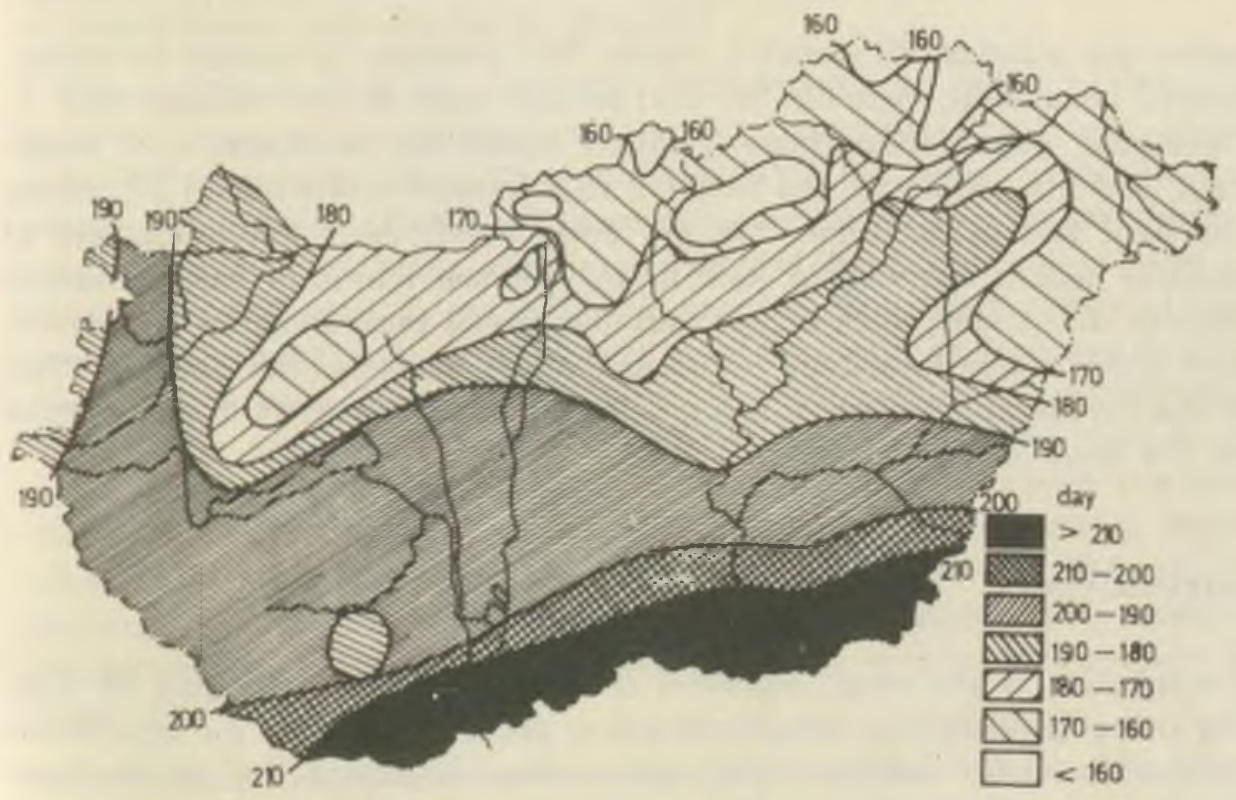

Fig. 10. Length of frost-free period (50-years averages) 


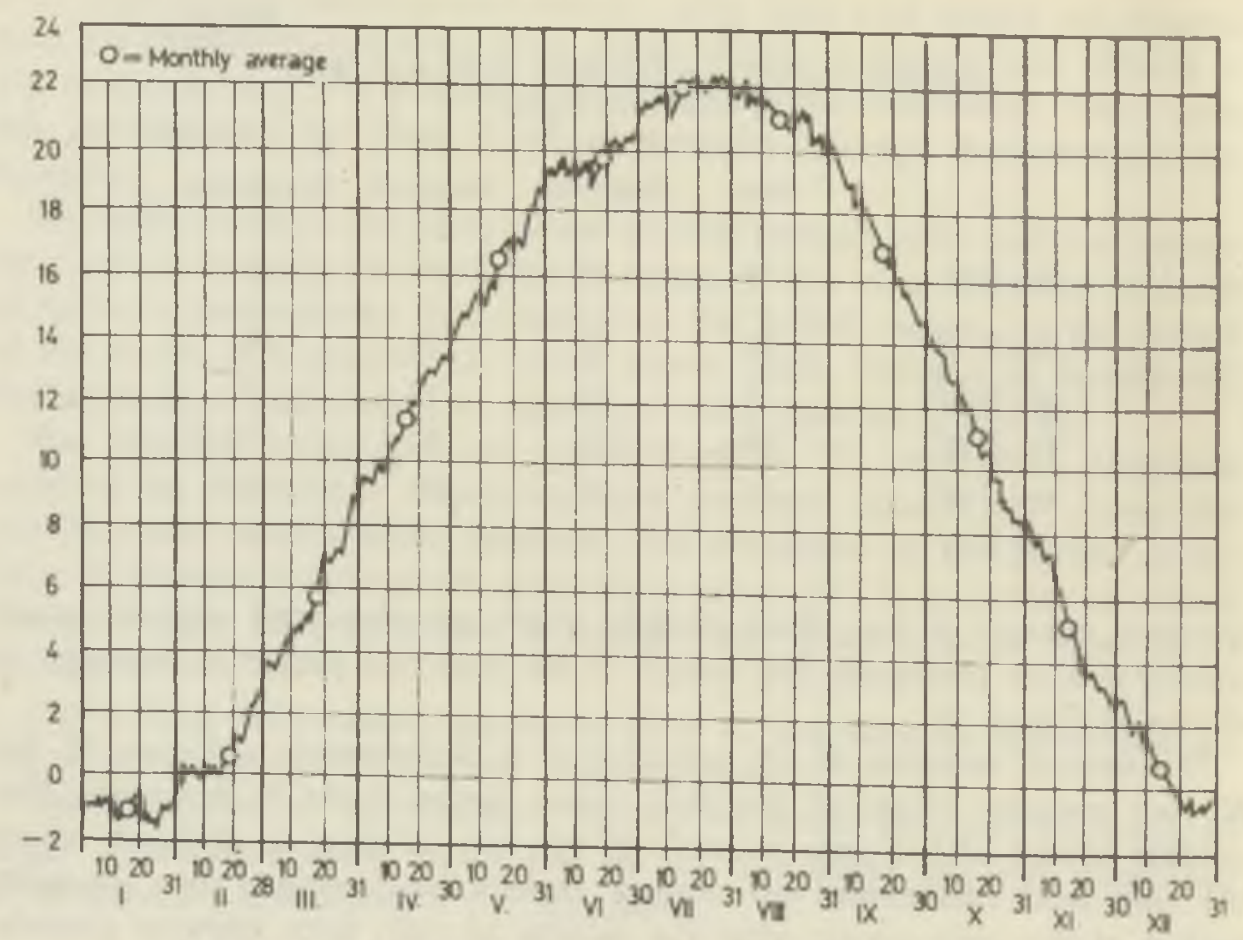

Fig. 11. Annual variation of air temperature (80-year averages)

follow the solatices by about a month. This situation is caused by atmospheric circulation. Actually, in the second half of the autumn and in December, mild Mediterranean currents retard the development of winter cold, and the nebulosity and frequent fogs formed in this humid air reduce the heat loss by radiation. On the other hand, the full development of summer heat is retarded in June by the summer monsoon that introduces Atlantic air masses which are, at that time of the year, still cool and humid. and which cause frequently occuring thunder showers. The cooling effect of the European monsoon in this country causes a reduction in temperature at the beginning of summer.

\section{PRECIPITATION}

Precipitation is the most important climatic element in Hungary because the actual precipitation conditions are a decisive influence on agricultural production. Solar radiation and temperature conditions are, in the overwhelming majority of years, favourable for the development of crops. Damaging values of these elements such as a too severe winter cold, a 


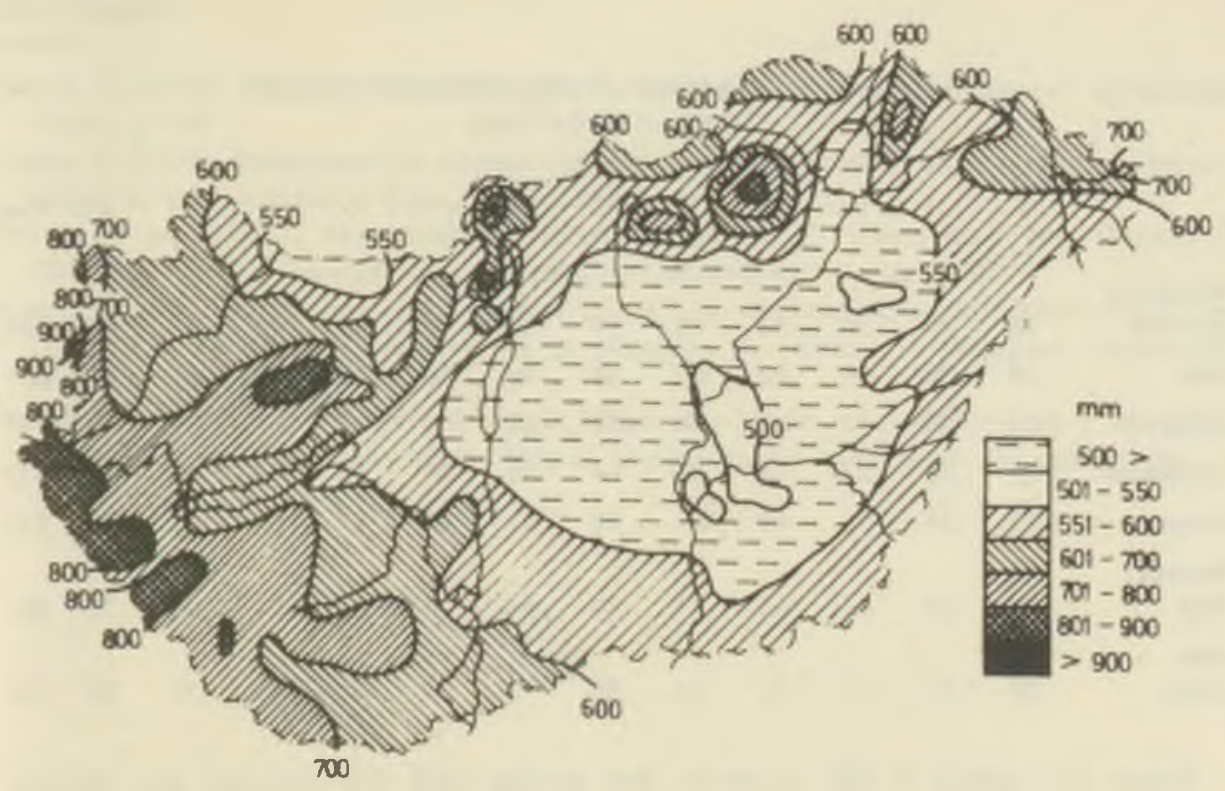

Fig. 12. Annual precipitation (50-year averages)

late-spring frost or a lack of insolation are rather infrequent. Accordingly, great damage to agricultural production mainly is caused by fluctuations in precipitation and mainly by droughts.

General information on precipitation conditions is provided in Figure 12, a chart of average precipitations from many decades. The lowest annual sum $(480 \mathrm{~mm})$ is found in the central parts of the Alfold while the most ample precipitation $(1000 \mathrm{~mm})$ is encountered along the western frontier, on the slopes of the Alps. In the entire area of the Alföld annual sums are lower than $600 \mathrm{~mm}$; in the hilly and mountainous regions they are between 600 and $800 \mathrm{~mm}$; while along the southwestern and western frontiers they vary between 800 and $1000 \mathrm{~mm}$. If these amounts of precipitation were evenly distributed in time. favourable conditions would exist in the entire country. According to averages of many decades, even the timedistribution of percipitation shown in Table 9 appears to be rather favourable since during the year there are neither periods of a distinctly dry character, nor periods with extremely abundant precipitations. In addition, the growing period for plants is generally richer in precipitation than the colder half-year.

Unfortunately, however, there are years with a rather erratic time distribution of precipitation with frequently occuring dry spells, and at other times but less frequently great excesses of precipitation. 
Table 9.

MONTHLY and ANNUAL SUMS Of PRECIPITATION

50 YEAR AVERAGES

I II III IV V VI VII VIII IX $\quad x \quad$ XI XII Year

$\begin{array}{llllllllllllll}\begin{array}{l}\text { Mosonma } \\ \text { gyaróvár }\end{array} & 36 & 34 & 38 & 43 & 65 & 57 & 64 & 58 & 51 & 49 & 51 & 48 & 594 \\ \text { Pécs } & 38 & 39 & 44 & 63 & 67 & 64 & 58 & 56 & 54 & 66 & 67 & 45 & 661 \\ \text { Budapest } & 39 & 39 & 43 & 52 & 69 & 67 & 50 & 48 & 45 & 54 & 61 & 50 & 617 \\ \begin{array}{l}\text { Kecskemét } \\ \text { Szeged }\end{array} & 26 & 29 & 32 & 44 & 55 & 54 & 48 & 44 & 46 & 48 & 50 & 37 & 513 \\ \begin{array}{l}\text { Nyıregv- } \\ \text { hàza }\end{array} & 29 & 30 & 32 & 44 & 61 & 70 & 64 & 68 & 46 & 51 & 50 & 38 & 583 \\ \begin{array}{l}\text { Peak } \\ \text { Kékes }\end{array} & 39 & 41 & 47 & 61 & 86 & 98 & 79 & 75 & 61 & 69 & 74 & 54 & 784\end{array}$

These dry spells in the summer, the spring and the autumn are accompained by strong insolation and by very high temperatures which speed evaporation transpiration. As a consequence, in these situations the water requirements of plants are not fulfilled and agricultural crops are strongly reduced as severe drought damages occur. More infrequently, on the other hand, a protracted abundance of precipitation accompanied by rather cold cloudy weather occurs. This situation causes floods and inundations by the elevation of the water-table in the soil. The tendency toward occurence of droughts led to the installation of irrigation works. while the excesses of precipitation require incessant activities in the field of hydraulical engineering and anti-inundation work. During the warmer period of the year, great concern is caused by the soil- destroying erosional effects exerted by thunder showers with a high precipitation intensity $(I=1-5 \mathrm{~mm} \mathrm{~min}$.$) , because in such cases the amount of precipitation$ can reach values of 100 to $200 \mathrm{~mm}$ within 24 hours. Once or twice a year these cloudbursts usually are accompanied by hail, but the damages it causes can only be mitigated by hail insurance.

The number of days in a year with precipitation is 80 to 110 including 20 to 30 days with snow in the winter. The formation of a durable snow cover is relatively infrequent. On the tilled lands, 30 to 600 days with a snow cover may be expected in the course of a winter. Its protective influence makes the cultivation of winter cereals possible. As a consequence of the invasion of maritime air masses, winter weather is rather unpredictable. Frequently thawing occurs during the day and the snow-cover is destroyed so that crops often suffer from subsequent frost damages. 
Bacsó, N. (1959). Magyarország éghajlata (Climate of Hungary). - Budapest: Akadémiai Kiodó, p 309.

Kakas, 1. (1960). Magyarország éghajlati körzetei (Climatic zones of Hungory). - Kandidátusi èrtekezès. Kézirat (Diss. manuscript).

Kakas, J. ed. (1960). Magyarorszóg éghajlati atlasza, I. Klima-Atlas von Ungarn I. (Climatic atlos of Hungary I.). - Budapest: Akadémiai Kiadó, p 97.

Kakas, J. ed. (1967). Magyarország éghajlati atlasza II. Számtáblázatok, Klima-Atlas von Ungarn. II. Tabellen (Climatic atlas of Hungary. II. Tables). - Budapest: Akadémiai Kiadó, p 261.

Péczely, Gy. (1957). Gross Wetterlogen in Ungarn. - Veröff. d. Zentralanstalt f. Meteorologie, Budapest: Országos Meteorológiai Intézel kisebb kiadványai, új sorozat 30. 



\section{THE HYDROGRAPHY OF HUNGARY}

M. PECSI - S. SOMOGYI

\section{The Evolution of the Drainage Network}

The present drainage network began to evolve at the very end of the Pleistocene epoch when the Pannonian-Pontian inland sea finally withdrew from the territory of the country. Originally the ancient Danube filled up the basin of the retreating Pannonian Sea in what is now the Little Plain. The river turned south in the Little Plain and, proceeding along the valley of the present-day Dráva, ended in the system of inland lakes in the southern part of the Great Plain. Later, the central portion of Transdanubia was uplifted and the Danube adopted a west to east course running towords what is now the Visegrad Gorge. At that time the relief there consisted merely of low hills among which the Danube found its way along a valley of faulted origin into the Great Plain. Since the Great Plain subsided greatly in the course of the Tertiary period, while the Transdanubian Mountains were uplifted, the Danube considerably incised the valley between Esztergom and Vác, and formed a terraced valley 200 to 300 metres deep.

Having passed through the Visegrád Gorge, the Danube built a vast alluvial cone on the edge of the subsiding basin of the plains. In the course of the Quanternary period the Danube broke up into several branches all of which flowed southeast towards the bed of the present Tisza, towards Cegled, and then towards Kecskemét and Szeged. The river occupied and began to shape its present north-south valley as the result of a small subsidence on the border of Transdanubia at the end of the Pleistocene epoch. Its evolution did come to an end, however, because in recent times before the flood control projects were put into effect it frequently changed its bed in some places.

The Danube also built up a huge alluvial fan in the Little Plain; its braidings on top of the fan can still be traced between Bratislava and Komárom. Its tributaries starting in the mountains developed partly somewhat earlier than, and partly contemporarily with the Danube itself.

The present course of the Tisza in the Great Plain also evolved in recent times. The Nyirseg plateau is an alluvial fan of the Tisza and its tributaries. At the end of the Pleistocene epoch the Tisza did not flow around the Nyirség in the north, but ran along its southern margin towards the middle of the Great Plain.

As a result of the evolution of the drainage network, two great rivers, the Danube and the Tisza, flow through Hungary. Nevertheless, the 


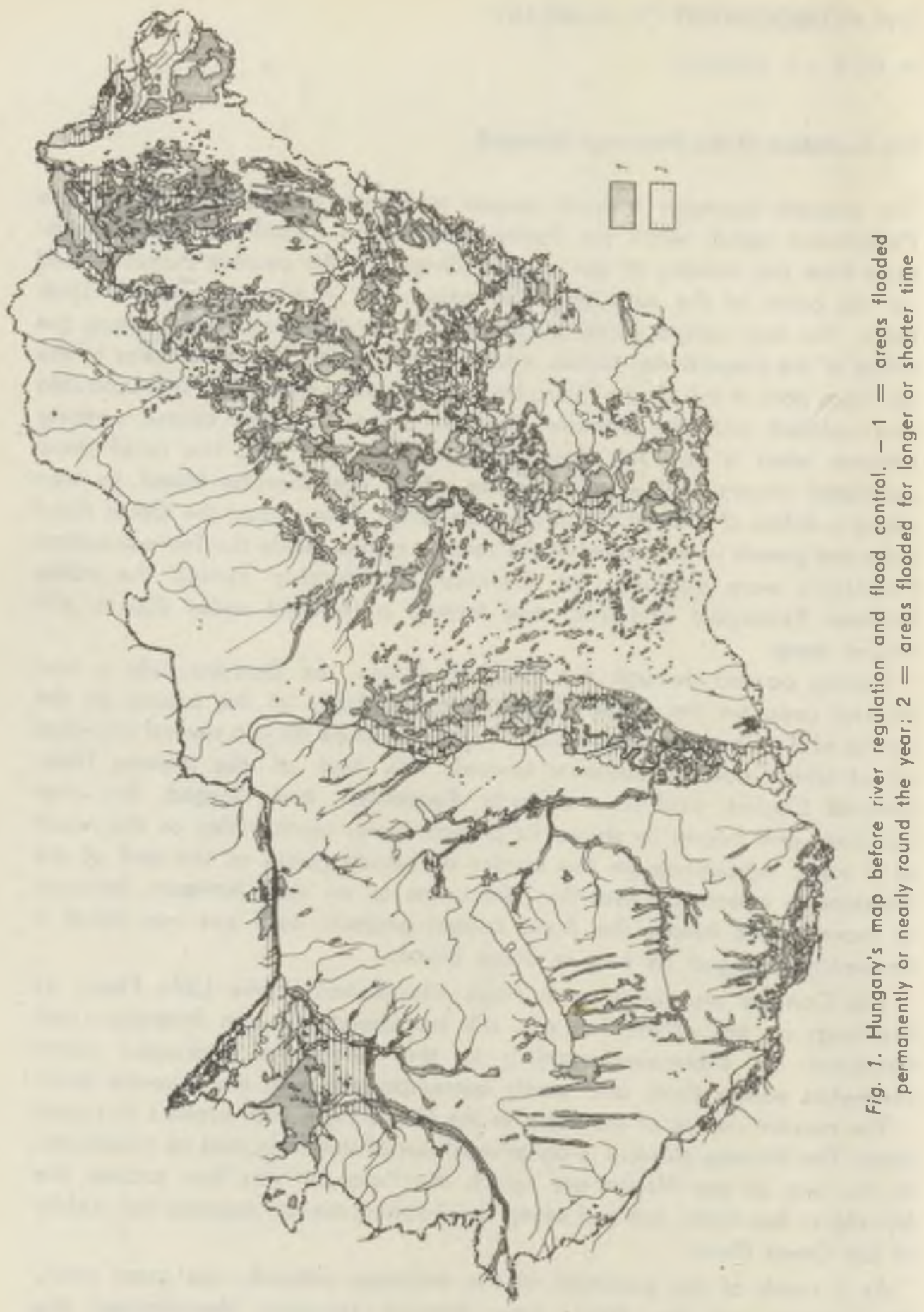


drainage mesh in the plains is none too dense for the tributaries are few and far between. There are small areas, mainly among the sand dunes of the Great Plain, which have insufficient drainage. Among the hills of Transdanubia and in the areas of the Hungarian Mountains there is a fair number of smaller water courses, though some of these dry out at times of drought. The rivers have no well defined valleys along their courses through the plains, while in their courses through the hills they run along terraced valleys (Figure 1).

\section{Surface Waters}

THE DANUBE AND ITS TRIBUTARIES

The Danube is the largest river of Hungary and of Central Europe, and the highway of the peoples of the Danube valley. Its catchment area of some $817,000 \mathrm{sq} . \mathrm{km} . \quad(306,000 \mathrm{sq} \mathrm{mi}$.) extends over nine countries. Its length is nearly $2,900 \mathrm{~km}$. (1,740 mi.) of which the Hungarian section is $417 \mathrm{~km}$. (244 mi.). In Europe its catchment area and length are second only to those of the Volga. The rather steeply sloping Upper Danube flows through German and Austrian territory. The Middle Danube begins in Hungary's Little Plain and continues through the narrower valley section of the Hungarian Mountains into the Great Plain and finally to the Rumanian-Yugoslavian Iron Gate Gorge. Hence, Hungary is situated in the basin of the Middle Danube which sometimes is also referred to as the Pannonian Basin (Figures 2, 3).

The discharge and regime of the Danube in Hungary are determinated by the flow of the Upper Danube and particularly of the right-bank tributaries stemming from the Alps, the most important of which is the Inn. The annual precipitation over the catchment areas of the tributaries which reach the Danube from the northern foothills of the Alps is very abundant, usually about 1,200 to $2,000 \mathrm{~mm}$. Depending on the fluctuations of Alpine precipitation and on the snowmelt in the mountains, the Hungarian Danube section has two regular floods each year-one in early spring and another in early summer. The floods are characteristic of the first half of the year, while medium water levels are typical in the summer period, and low waters are more frequent in the autumn and winter months (Figure 4).

The early spring flood of April or May is not so high as the early summer flood. It is caused by the snowmelt in the lower regions along the upper reaches of the river. This flood is mainly the result of the coat of ice. The ebb is slow and gradual because the snowmelt frequently provides re- 


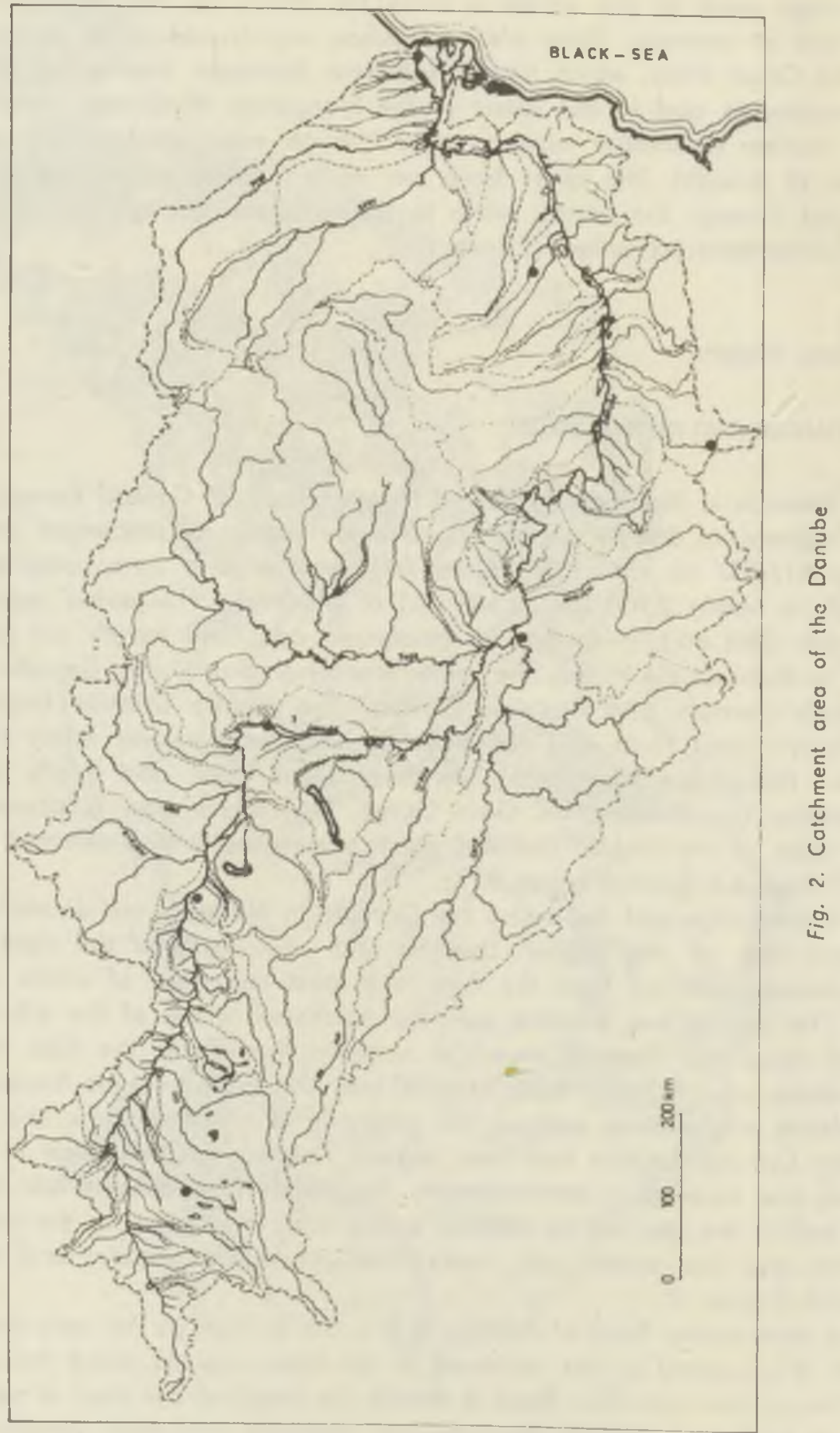




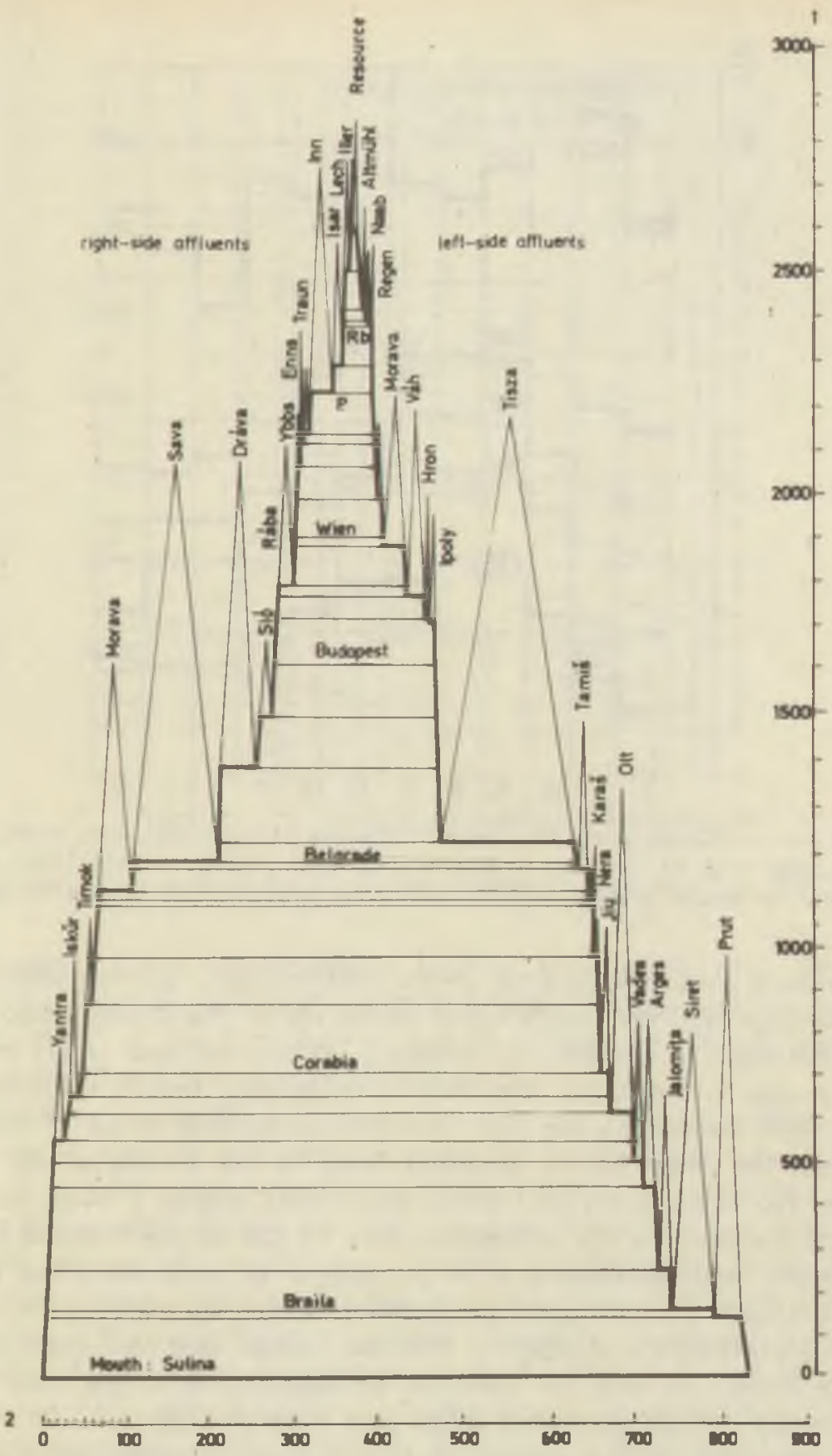

Fig. 3. Structure of the river system of the Danube. At the mouths of the tributories horizontally the catchment area in square kilometres, vertically the length of the tributaries in kilometres are demonstrated (after $W$. Lászlóffy). $-1=$ length of rivers in $\mathrm{km}$ : $2=$ catchment area in $1000 \mathrm{~km}^{2}$ 


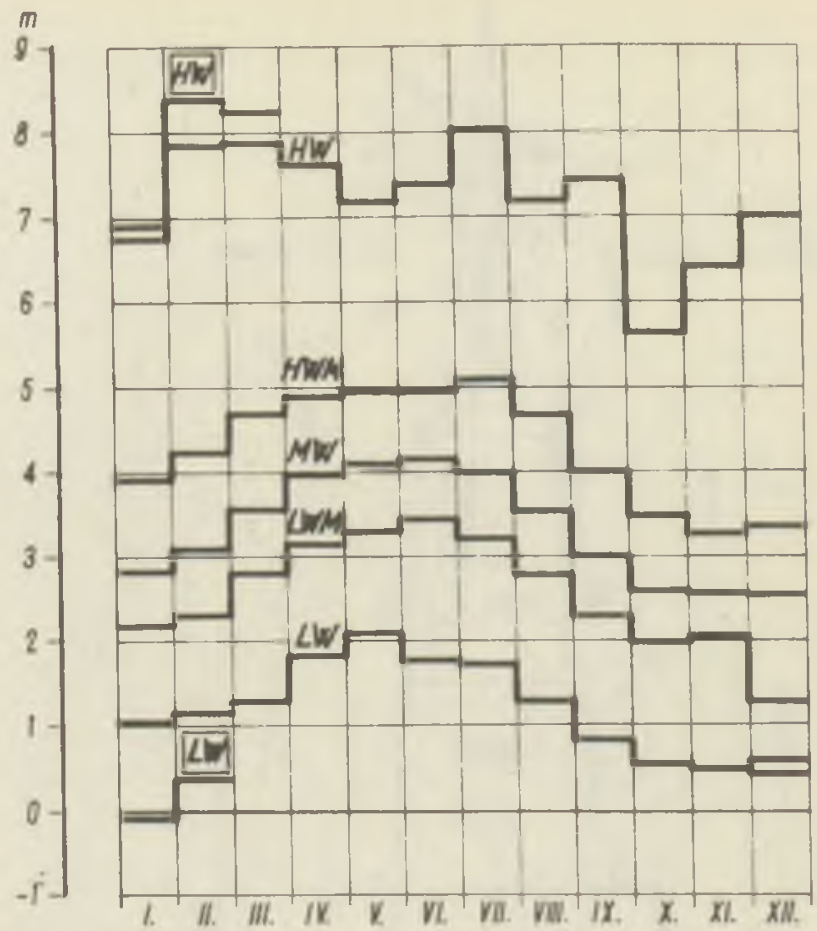

Fig. 4. The water Duaget of the vanuoe at buoapest. Lnatucteristic nule levels between 1901 and 1960 (after W. Lászlóffy). - HW = High Water: HWM = High Water Medium: $\mathrm{MW}=$ Middle Water $; \mathrm{LWM}=$ Low Woter Medium; $\mathrm{LW}=$ Low Water

charges for a considerable time. In the past the early spring floods caused great damage, for they usually broke up the ice on the Danube and carried off the ice floes. In general, the breaking up and removal of the ice cover begins earlier in the upper reaches of the Danube than in the Hungarian section. It is caused by the fact that the ice-melting effect of the warm front from the West occurs generally later in the basins of the Middle Danube. Especially heavy and dangerous floods originate when the thawing starts suddenly in the catchment area of the Upper Danube because of the warm rainfalls coming from the ocean. In such cases the drift ice from the Upper Danube piles up in front of the ice cover still unbroken in several parts of the Hungarian Danube section and frequently an "iceplug" is formed. It was, for instance, an obstruction of the river bed by an "ice-plug" which destroyed Buda and Pest in 1838.

The rate of flow of the "green flood" in the early summer flood is higher than that of the early spring flood. In June the Danube's discharge is greatest due to the late spring and early summer rains over the catchment area of the Upper Danube: moreover, the snowmelt reaches the snowfields 


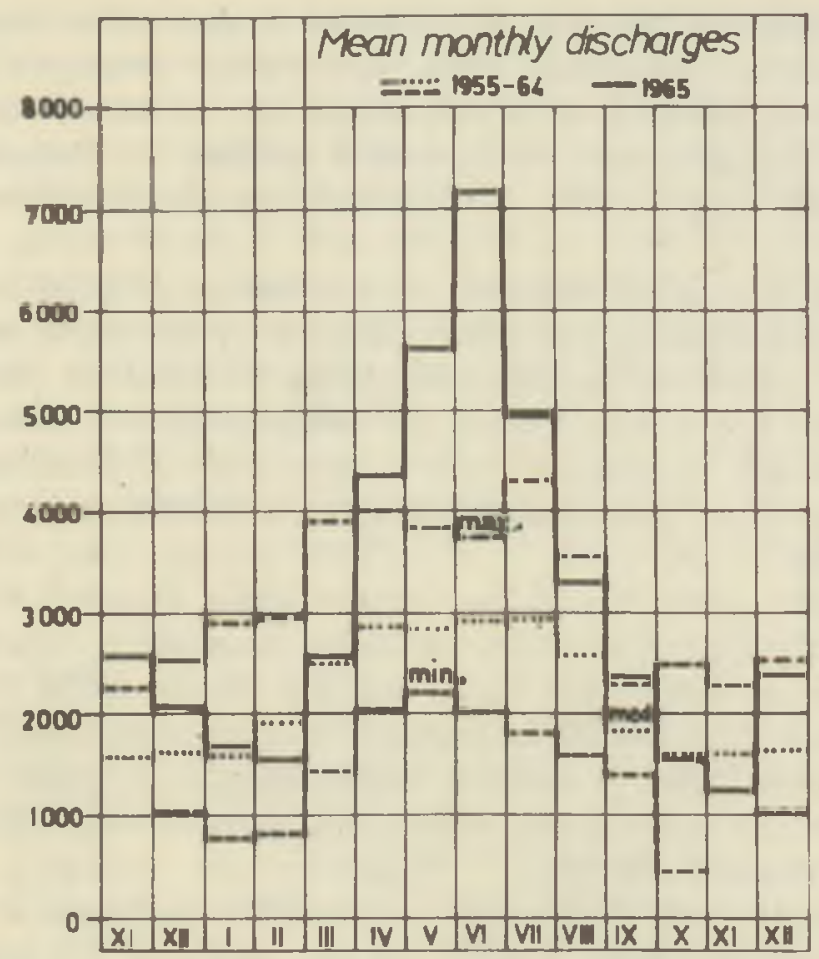

Fig. 5. Monthly medium water output of the Danube in budapest 1ysj-1964 and 1965

and glaciers of the higher Alpine regions around this time. The early summer floods of the tributaries of the Middle Danube run down earlier than the flood of the Danube, so that the tributaries do not affect the early summer flood of the Danube (Figure 5).

The Danube generally is lowest towards the end of summer or the beginning of autumn and also occasionally in the winter. In extremely dry years the low water level may hinder shipping, but ordinarily the Danube is navigable during the whole year except in dry and cold winters when it is covered with ice for several weeks. The discharge of the Danube at Budapest is $600 \mathrm{~m}^{3} \mathrm{sec}$. at the lowest water level, and $10,000 \mathrm{~m}^{3} / \mathrm{sec}$. at the highest. The water level difference between the highest and lowest levels is as much as 8 metres (26 ft.) yearly. Experience has shown that in constructing dams, flood waves of a maximum of 10 metres (33 ft.) above low water level have to be reckoned with on the Great Plain.

The Danube, however, does not freeze every year. At Budapest, for instance, it is on the average only every second year that the Danube freezes over, and then freezing usually occurs in the period between December 25 and February 25. With the exception of the periods of drifting 
ice and of complete freezing, the Danube is navigable throughout its Hungarian section. Significant trade takes place among the countries lying along the Danube. Smaller sea vessels can be in service up to $\mathrm{Bu}$ dapest. While Hungary does not possess a seaport, the Danube is a very important water way to the seaports of the Southeastern European countries.

The Danube is of great economic importance not only for transport but also in supplying drinking and industrial water to the towns on its banks. In addition, ever increasing areas are being included in the irrigation schemes whose water requirements are supplied by the Danube. It is a very important task to safeguard the Danube's clarity because the towns settled close to it can only be supplied with satisfactory quantities of water by the Danube.

The right-bank tributaries of the Danube within Hungary have a small discharge. In the Little Plain there are larger rivers which include the Lajta and the Rába, as well as the Répce and the Marcal which flow into the Danube at Gyốr. From the Transdanubian Mountains only small brooks flow into the Danube. Only the Sárviz is worthy of note. It meets the Danube with the Sio, which is the gutter of Lake Balaton. The Kapos flows into the Sió before it meets the Sárviz.

The only right-bank tributary of appreciable discharge is the Dráva (Drave). Its catchment area is $40,000 \mathrm{sq} . \mathrm{km}$., and it is $720 \mathrm{~km}$. long. This river constitutes the Hungarian-Yugoslav frontier, but its mouth lies in Yugoslav territory. The Dráva has as many as three floods, one in early spring, the second in early summer, and the third (a Mediterranean feature) in early autumn.

Some of the left-bank tributaries of the Danube flow from outside of Hungary, and their mouths are located along the Czechoslovak border: the rest are insignificant.

\section{THE TISZA}

The Tisza is a typical flatland river. Along the central, lowest section of the Great Plain the river meanders lazily. The country along the Tisza has a peculiar aspect of its own-the vast sinuous loops of the river, the willow groves of the flood area, the cut-offs and silted-up fens and oxbow lakes, as well as the frequent bank dunes give the extensive flood plain of the river a varied aspect. Until the middle of the last century when the Tisza was regulated, it frequently changed its bed in its extremely wide flood area. The heavy and frequent floods inundated nearly two million hectares of land. The stretch of the Great Plain along the Tisza at that time was little more than a sea. 
The regime of the Tisza is very changeable, its water level fluctuation is three to four metres greater than that of the Danube. The Tisza also has two floods - one in early spring, the other in early summer - and like the Danube, its early summer flood is higher. The early spring flood on the Tisza comes from the snowmelt in the Carpathian and Transylvanian ranges. The spring floods of this river and its tributaries usually overlap; the culminating points, however, do not coincide, so that they do not reinforce one another. The early spring floods of the Danube and the Tisza also frequently occur at the same time. The Tisza cannot discharge into the Danube and it swells rapidly. This circumstance caused the disastrous Szeged flood in 1879 which devastated the whole city. There are no iceplugs on the Tisza because the warm air masses from the southwest melt the ice of the lower regions before that of the upper reaches (Figure 6).

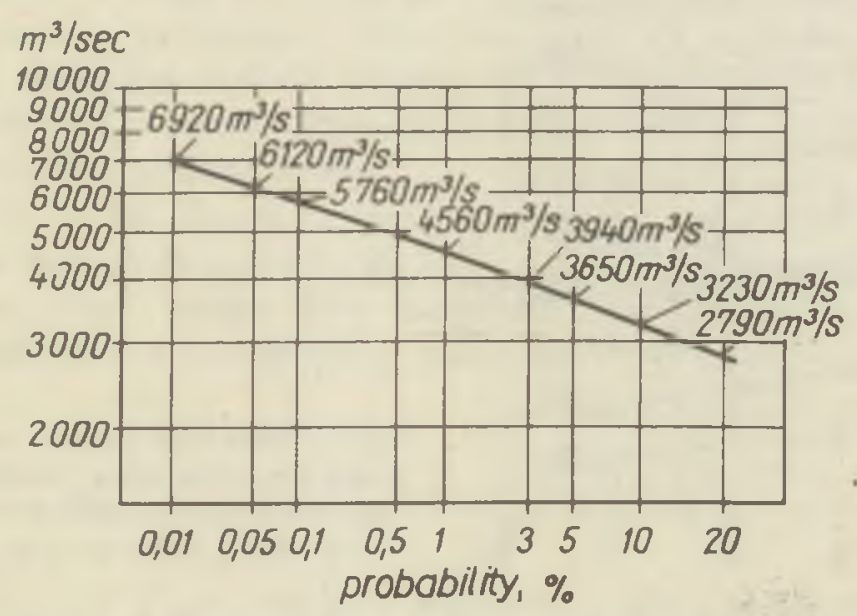

Fig. 6. Flood discharges of different probability of the Tisza, at Szeged (after W. Lászlóffy)

The early summer flood is due exclusively to rainfall, and arises simultaneously on the Tisza and on its tributaries. Its vehemence decreases from north to south. The early summer floods of the Danube and the Tisza do not usually concur, as the early summer precipitation maximum occurs earlier in the upper reaches of the Tisza. East of Tokaj there also occasionally is a second maximum of precipitation in October which can result in a third flood-wave, but it is attenuated as it progresses downstream.

It is most characteristic of the extreme regime of the Tisza that at Szolnok it transports 53 times as much water at flood stage as at low water (72 $\mathrm{m}^{3} \mathrm{sec}$. at low water, $3,800 \mathrm{~m}^{3}$. sec. at flood stage). In the upper reaches of the Tisza the difference between low water and flood stage is even 
greater. At Vásárosnamény, for example, the flood discharge is 87 times the discharge at low water (Figure 7).

Because of the decrease in water level after regulations, the Tisza until recently was navigable by larger ships only up to Szolnok, while smaller ones could only proceed to Tokaj. The Tiszalök Dam, completed between 1952 and 1954, however, made the Tisza navigable up to Dombrád, and the Bodrog navigable up to Sárospatak. At Tiszalök the water is conducted by the East Main Canal at a rate of $60 \mathrm{~m}^{3} \mathrm{sec}$. to the droughty land of the Körös. With the aid of this canal irrigation takes place on about 140,000 hectares. The dams also produce electric power.

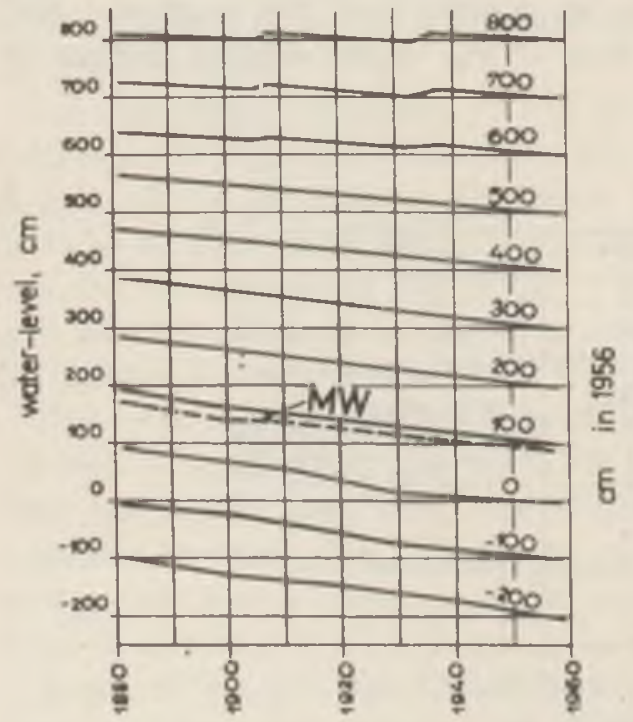

Fig. 7. Water-level changes caused by bed deepening taken place between 1880 and 1960 in the case of identical water output in the profile of the Tisza at Szolnok

At present north of Szolnok at Kisköre the second Tisza Dam is under construction. It will provide enough irrigation water for 350,000 hectares.

The most important of the right-bank tributaries is the Bodrog, a union of five rivers, which joins the Tisza at Tokaj. Like the Tisza, it is a meandering. characteristically graded river. The point of confluence of the two rivers has changed frequently. The changes are clearly shown by the numerous oxbows and point bars in the vicinity of Tokaj.

The Sajó is joined by the Bódva in the Miskolc Gate, and further south, on the margin of the Great Plain, it unites with the Hernad before it joins the Tisza. Below Tiszafüred, the Tisza is joined by the Eger, and at 
Szolnok it meets with the Zagrva which carries the waters of a few smaller rivers. Further downstream the Tisza does not receive so much as a single stream from the sand plateau between the Danube and the Tisza. The eastern margin of the sand plateau is only furrowed with dry valleys.

The left-bank tributaries of the Tisza are of greater importance. The Szamos and the Kraszna join the Tisza in the vicinity of Vásárosnamény. These two rivers carry the water excess of the northern part of the Transylvanian Basin into the Tisza. It was with the help of the system of canals connected with the Kraszna that the marshes of the Ecsed Swamp, a subsidence between the Nyirség and the Érmellèk Districts, were drained.

The Körös carries the waters of five smaller rivers into the Tisza. The liver resulting from their confluence is called the Hármas Körös (Triple Körös). Like the Tisza it is a graded river: it meanders a great deal and often has changed its bed. Along the banks of the Körös irrigation is practised over a large area. Between the three rivers - the Körös, the Berettyó and the Hortobágy - there was once an endless swamp called the Sárét. Now the area is covered by a network of irrigation canals extending several hundred kilometres and by a network of drainage canals many thousand kilometres long.

The Maros is the largest tributary of the Tisza but only a short section of it flows through Hungarian territory. It is $754 \mathrm{~km}$. (467 mi.) long and collects the water excess from $30,330 \mathrm{sq} . \mathrm{km}$. (11,700 sq. mi.) in the southern part of the Transylvanian basin.

\section{Flood Control, River Conservation and Water Economy}

The Danube, the Tisza and their tributaries flow in the plains in flatbottomed beds with no valleys. In former times, every flood inundated vast areas paralyzing transport and agriculture for prolonged periods. Many settlements were frequently confronted with disaster. The lower portions of the flood plains were under water for most of the year and were swampy. reed-covered areas with almost no economic use. Until the middle of the last century there were some one million hectares of swamps along the Danube and well over two million hectares of swamps along the Tisza which were practically useless for agriculture. A map of ancient hydrography gives a fair idea of these conditions.

With the building of railways in the second half of the last century. the European market opened up for Hungarian grain. Consequently, it was in the interest of the landowners to expand agriculture over ever larger areas. 
Large scale embankment and regulating works began in Hungary. On the basis of the organization work of Istvan Széchenyi and the plans of Pál Vásárhelyi the beds of the Danube and Tisza were regulated so that floods could rush down more rapidly. For this reason a lot of oxbows were cut off. By regulating and cut-offs, the course of the Tisza was shortened from $1419 \mathrm{~km}$. (810 mi.) to $966 \mathrm{~km}$. (540 mi.). The progress of the flood waters

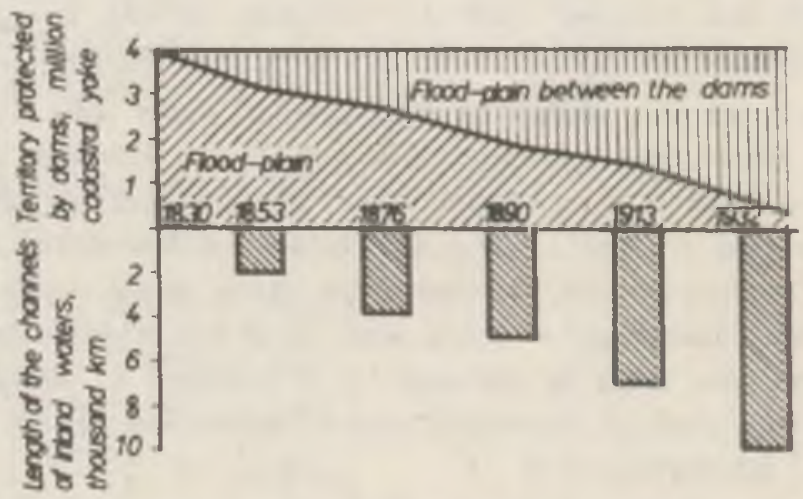

Fig. 8. Change of the drainage canals and of the extent of the area protected by dams in the Tisza Valley between 1830 and 1932

therefore was greatly accelerated and the danger of inundations considerably diminished. In the case of the Danube, the cut-off of meanders and the dredging of the bed served to eliminate the frequent jamming of drift ice, the main cause of heavy floods. To prevent the inundation of the flood plain levees were constructed along the banks of the rivers. The length of the flood levees along the Danube and the Tisza is over 4,000 $\mathrm{km}$. $(2,400 \mathrm{mi}$.). The main settlements on the banks of the Tisza, moreover, are protected against possible floods by circular levees (Figure 8 ).

Besides protection against floods another aim of river conservation was to eliminate the fords and shoals to make shipping and goods traffic along the Danube and the Tisza reliable.

The lands freed from the floods by these projects ought to have been irrigated, but the construction of irrigation canals was neglected. In the last decade, irrigation in the Great Plain was promoted by the government of the Hungarian People's Republic. A long-term plan for water economy was formulated, and hundreds of thousands of hectares of irrigated land east of the Tisza bear witness to the results. 


\section{Subterranean Waters}

\section{GROUND WATER}

In general, the water in the superior water-containing layer is called ground water (ground water is a free water surface which is not pressed by other layers). Such ground water of free water table can be found in the Little Plain, in the Transdanubian Hilly Region, and in the areas of wind-blown sand of the Great Plain. In a great portion of the territory east of the river Tisza, however, the first water table lying near the surface is not the ground water of the free water table, because impermeable sediments can be found over large areas. The water in the first watercontaining layer is under pressure. According to research the ground water rises by one to three metres before reaching its level of repose. It was also ascertained that in the Great Plain the ground water-containing layer is dissected by a number of mud and clay lenses which distribute the layer of ground water. These layers are not bordered by continuous impermeable substratum, and therefore the water of the deeper watercontaining layers can be in connection with that of the superior one (Figure 9).

The origin of the ground water of the Great Plain has been discussed many times. Of course, on the loess surfaces, on sands and alluvial fans a great part of precipitation infiltrates except in case of impermeable surfaces covered with clay. The water supply of the water-containing layers lying under these strata comes from the surface precipitation of the basin's margins. Here a lot of rainwater collects, and on the alluvial fans of the foot of mountains the infiltration takes place easily; the evaporation, however, is insignificant.

The rainwater infiltrating the margins of the mountains is thus drained off by the gravel beds of the river deposits and by the loess deposits sand and gravel - of the alluvial fans, which subside deeply under the surface and protrude into the heart of the Great Plain. The water accumulating in such a way is stored in the water-sustaining layer system of the great basin which is dissected by sandy-ravelly and sandy-clayey strata. The ground water of the Great Plain is supplied by the upper level of these aquifers, and its lower level supplies more than ten thousand artesian wells.

To a certain extent the basin of the Little Plain is dissimilar because its center is an alluvial fan of 50 to 100 metres depth of the Danube and its tributaries. A great portion of the alluvial fan consists of gravel. The ground water is potable, clean, plentiful, easily accesible and of rapid 


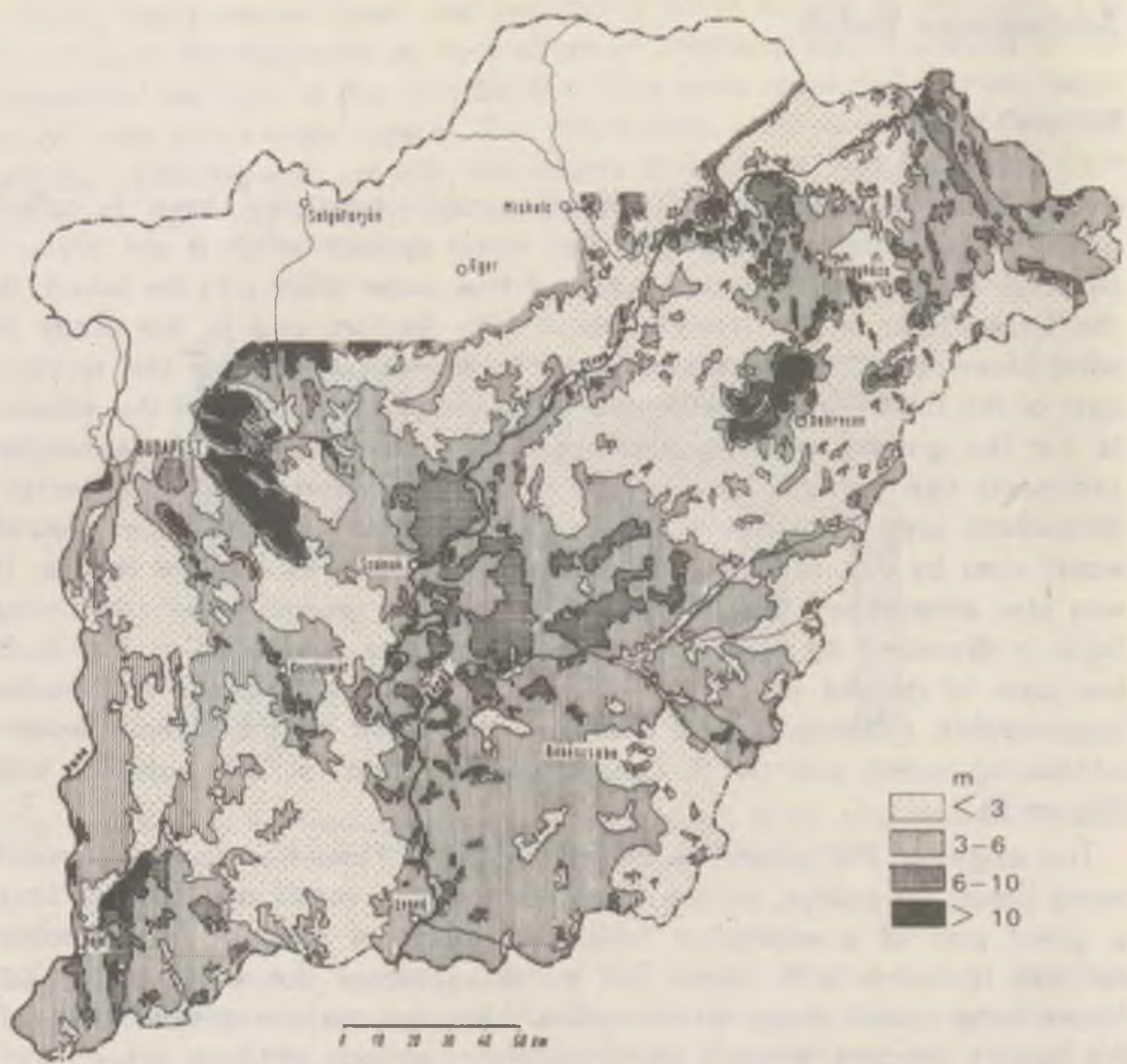

Fig. 9. Average depth of the ground-water table under the surface in the Great Hungarian Plain (1950-1959) (after A. Rónai and B. Bóczán)

ing water of the rivers, and by the rainwater collected in the margins. The ground water is potable, clean, plentiful, eaşily accesible and of rapid motion in the gravelly sediments of the flood area of the Little Plain, and in its higher western part covered by gravels.

Inside the Great Plain and principally in the territory east of the Tisza, the ground water moves slowly in the fine-grained sediments and dissolves from them a lot of mineral salts. The ground water in the Great Plain is immensely rich in dissolved substances. Often it is too hard to drink and usually it is calcareous.

The general rule for the positon of the ground water table is that in areas covered with loess, its depth corresponds to the thickness of the loess. In the Great Plain it may be 6 to 12 metres, or even deeper. In 


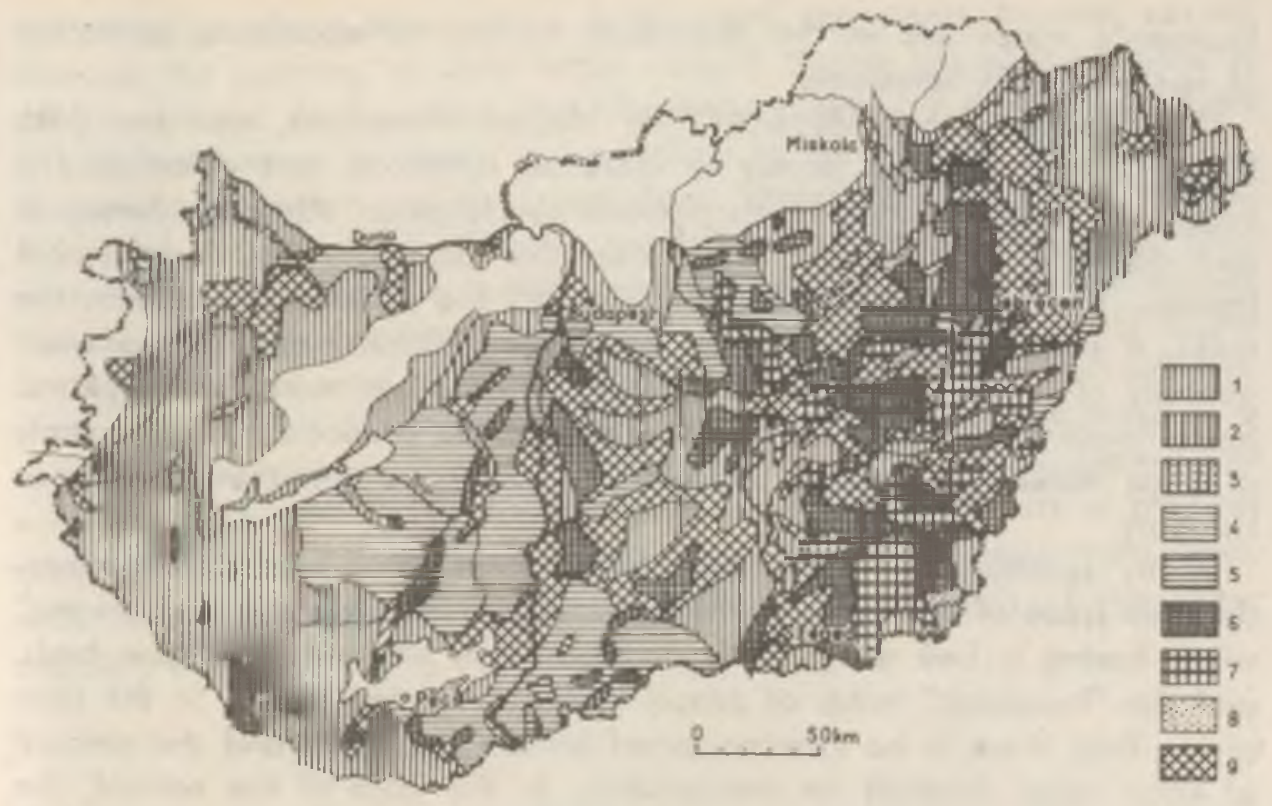

Fig. 10. Chemical characters of ground-water samples in Hungary (after A. Rónai). The signs show the salts which occur most frequently and with greatest weight per cent in the ground-water of the area. $-1=$ ground-water with calcium hydrogen carbonate; $2=$ ground-water with calcium sulphate; $3=$ ground-water with calcium cloride: $4=$ ground-water with magnesium hydrogen carbonate; $5=$ ground-water with magnesium sulphate (bitter-salty water): $6=$ ground-water with natrium hydrogene carbonate (alcalic, sodic water): $7=$ ground-water with natrium sulphote (glauber salty water): $8=$ ground-water with natrium cloride; $9=$ ground-water of mixed, varied character

areas of aeolian sands and in the river valleys, on the other hand, it may be reached at 2 to 5 metres. In the deeper flood plains it is located within 1 to 2 metres of the surface. The flood plains of the Danube store vast quantities of water. This is proved by the fact that the enormous water requirements of Budapest are, for the most part, satisfied from ground water. North of the capital water is pumped from hundreds of wells dug in the terrace gravel layers on the islands and on both banks of the river (Figure 10).

\section{KARST WATER}

Karst water, too, plays an important part in the economic life of the country. On the one hand it is useful for industrial and drinking purposes but on the other it is harmful when encountered as waste water in the mines where it has to be kept out by costly protective measures. Most of 
Hungary's mines are in the immediate vicinity of mountains consisting of easily karsted limestone.

The Transdanubian Mountains, the Mecsek Monutains, and the Bükk Mountains are built up mainly by mezozoic limestone and dolomite. The surface of these mountains gets plentiful precipitation. Although limestone and dolomite are compact rocks, they are permeated by innumerable fissures. Through these fissures and through the systems of caves in the rocks, a significant portion of the rainwater infiltrates and only a small quantity of it flows down on the slopes and valleys towards the plains. Since flooding by karst water is a frequent threat to coal mining, the study of karst water has become a practical problem of great importance in Hungary.

Briefly summarizing the investigations carried out so far, it appears that two types of karst water can be distinguished: the shallow, "epikarst" water having a free water table and stored in elevated limestone beds. and the "hypokarst" water of deeply subsided karsted blocks. In the case of the first, there is no interconnected karst water table and the amount of karst water depends on precipitation. In the case of the second, the level of karst water is interconnected over larger areas and less dependent on local precipitation. This latter so-called deep karst water is connected with the subsurface water circulation of the entire Hungarian basin, and therefore the deep karst water resources are practically inexhaustible.

The water holding capacity of the epikarst is not so large so that the water has a short route and can reach the surface, usually at the foot of the hills. Its supply from precipitation is obvious and always observable.

The water holding copacity of the hypokarst is vast and it possesses an interconnected water table of large extent. The flowing and dissolving capacity of the water is very small. In the zone of the deep karst the caves storing the water did not originate by cave erosion. The caverns of the deep karst are sometimes the levels of the former shallow karst which have subsided. They also can be of tectonic origin and caves dissolved by hot springs.

Some parts of the Hungarian Mountains which consist of Mezozoic rock have, in the course of time, subsided and been covered by more recent impermeable marine sediments. In these cases so-called buried karsts were formed, as opposed to the uncovered free karst that has been discussed. Obviously, the karst water of the subsided, buried karsts could not originate from local precipitation. They are covered in the depth with a real network of subterranean drains. The drains of the deep karst are interconnected with the water holding layers of the loose sedimentry rocks deposited on and near it, and thus it is in connection with subsurface water system of the whole basin. 
Knowledge about these caves is of great importance in coal mining because the opening of karst water caverns during mining operations is very dangerous. At the same time, the karst water is a significant benefit in supplying water to many towns settled in the margins of mountains. The springs and baths of Budapest, Tata, Várpalota, Eger, Pécs, Miskolc, Ajka, and Veszprem, for example, depend on this water supply. In these settlements karst water is brought to the surface by different techniques including wells, collecting systems, and gallery systems. This water is the basis of the local water supply - purified water for drinking and softened water for industry. In the coal and bauxite mining industries there is a special problem of preventing the disappearance and regime decrease of wells caused by the sinking of the karst water table. Numbers of physical geographers are working among the Hungarian karst researchers, who, with their research work have contributed to the solution of the water supply problems of many settlements.

\section{Confined Ground Water in the Plains}

In the Great Plain and also in other areas the phreatic water is generally unfit for drinking due to its contamination, its hardness, and its high mineral content. The water of the deeper aquifers, however, is clear and healthy. It is brought to the surface by pumpoperated wells from 50 to 100 metres or even greater depth. It may also reach the surface through freely effluent, positive artesian wells. There are about 25,000 of these in the Great Plain and nearly 15,000 over the rest of the country. Most of the wells in the Great Plain draw on the sandy and gravelly beds deposited in the Quaternary period. The aquifers are isolated from one another by layers of clay and mud. The water resources of the aquifers are practically inexhaustible. The recharging of these beds takes place in the plains largely through precipitation in the marginal parts of the basins. According to other opinions, there are processes of rock diagenesis in progress in the sedimentary series of the plains by which water bound by the rocks is liberated and joins the underground water circulation (Figure 11).

In the period of planned economy during the last decades, the demand for drinking and industrial water has greatly increased. New towns and large numbers of new factories and plants have been established. As a result, the number of artesian wells and local or regional water works has considerably grown, and further rapid development is planned. 


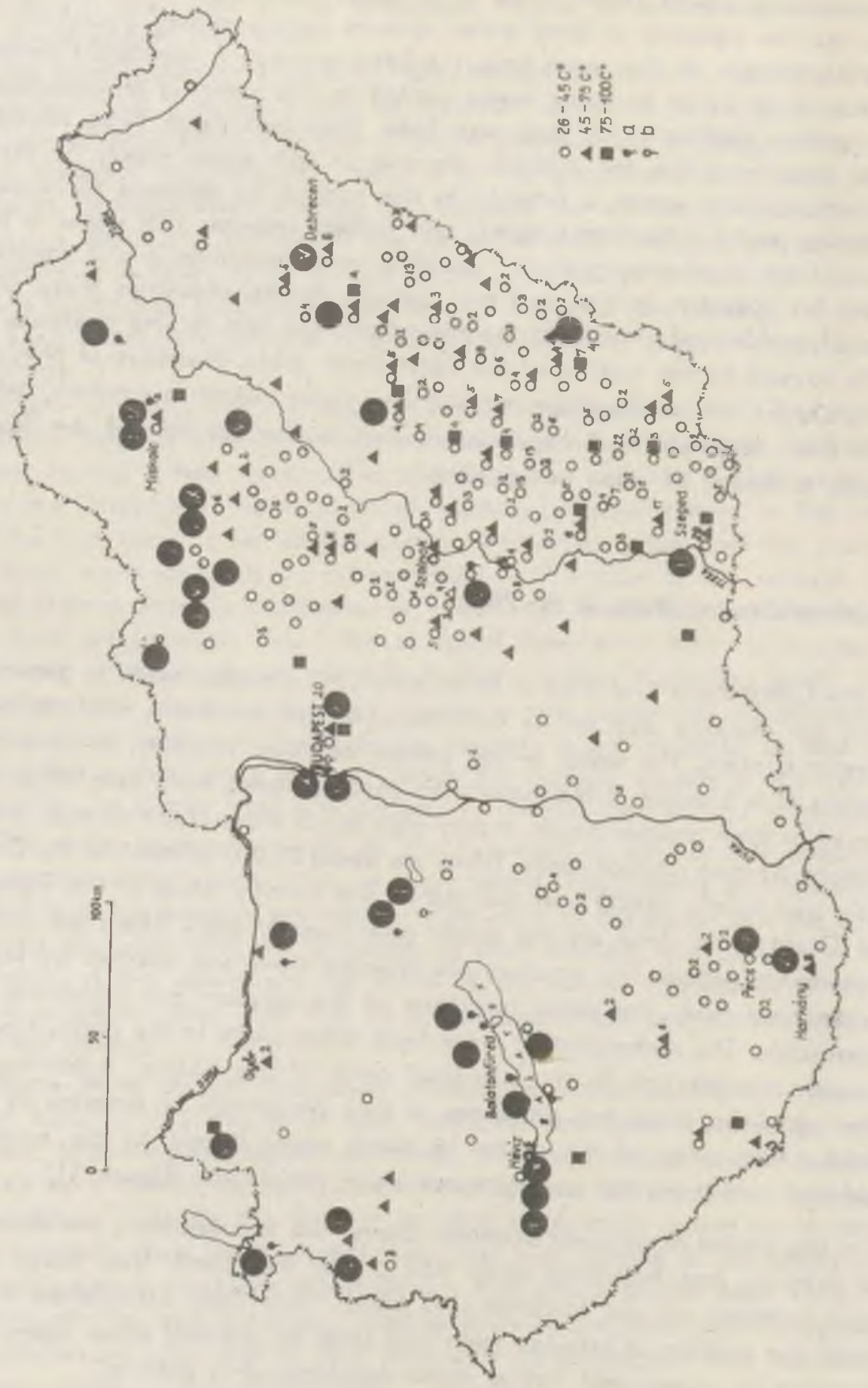




\section{Lakes, Marshes and Nature Reserves}

It was on the margins of the Great Plain, where the emerging and subsiding areas contact that standing waters of more or less free water surface developed in the subsidences of the latest geological past. Their evolution also was due to the fact that flood waters were left behind in large poorlydrained areas among the alluvial fans of the rivers which flowed inward in the basins.

In Transdanubia and in the subsidences of the southern foreground of the Transdanubian Mountains, large lakes originated of which only Lake Balaton and Lake Velence have open water surfaces. The Sárrét and Zámoly basins in Fejer County as well as the Pécs Basin in the southern foreground of the Mecsek Mountains are swampy. There are a lot of small valleys with bad outflow among the sand-hills of Somogy and hills of Zala counties. Lake Fertó and the Hanság, closed into the alluvial fans of the Danube and Raba are the shrunken remnants of the former swampland.

The largest Hungarian lake is Lake Balaton. It is the largest body of standing water in Hungary and in Central Europe. It frequently is called the "Hungarian Sea". The graben depression of Lake Balaton is quite young and was formed by stepwise subsidence along faults of SW-NE direction, at the end of the Pleistocene epoch. Lake Balaton and its environment became an object of detailed geographic and geological research as early as the end of the last century. There are not many lakes on the earth studied so thoroughly from the geographic point of view as Lake Balaton and its environment.

The water surface of Lake Balaton is approximately $600 \mathrm{sq} . \mathrm{km}$. (230 sq. mi.). Its greatest length is $77 \mathrm{~km}$. (46 mi.,), its greatest width $14 \mathrm{~km}$. (8 mi.). For a lake of its size, it is exceedingly shallow -3 to 4 metres ( 10 to $13 \mathrm{ft}$.) on the average. The deepest part, called the Tihany "pit", is only 11 metres (36 ft.), in depth.

The northern shore, defined by a fault, drops off rather suddenly to a depth of 3 to 4 metres from a narrow, rocky and reed-grown shoreline. In the south the lake bottom begins to rise 500 to 1,000 metres offshore

Fig. 11. Thermal and mineral medicinal woters in Hungary in 1966 (after R. E. Schmidt, a simplified version) with the indication of the temperature of thermal waters, and that of the chemical composition of mineral and medicinal waters (I-IX) (On the figure the numbers beside the signs mark the number of dug wells, the signs indicate the average of their data). - $\mathrm{a}=$ spring, dug well; $\mathrm{b}=$ bored well. $\mathrm{I}=$ acidulous water; II = water containing $\mathrm{NaHCO}_{3}$; III = water containing $\mathrm{Ca}-\mathrm{Mg}$-hydrogen carbonate; IV = water containing $\mathrm{NaCl}_{i} \mathrm{~V}=$ water containing sulphate (bitter-salt, glauber-salt); $\mathrm{VI}=$ water containing $\mathrm{Al}-\mathrm{Fe}$-sulphate; $\mathrm{VII}=$ water containing sulphur; $\mathrm{VIII}=$ water containing J, $\mathrm{Br} ; \mathrm{IX}=$ radioactive woter 
and forms a wide, flat, sandy beach, the longest lacustrine beach of Europe, extending along the southern shore of Lake Balaton a distance of 70 kilometres. Its fine, velvety sands and shallow waters, which warm up considerably in summer, make it a paradise for bathers. In the shallow water there are long, parallel, wave-built, underwater sand bars.

The volume of Lake Balaton ( 1,800 milliom $\left.\mathrm{m}^{3}\right)$ is rather small owing to its shallow depth. Its large surface evaporates more water yearly than can be recharged by the precipitation over the lake. The balance is restored by the Zala River and by the streams flowing into the lake along the northern shore. The water level of the lake is variable; it attains the highest level in April or May, and the lowest in October or November. The water level fluctuation, as observed through several decades, does not exceed 2 metres, though there is some evidence suggesting that in the Holocene epoch the lake, or part of it, dried out twice. Soon after its formation, however, the lake probably attained a level exceeding the present one by 6 to 8 metres, as confirmed by the evidence of higher sand bars and abrasion terraces of those times. At that time, the lake covered a much greater surface. The waters of Lake Balaton also rippled in the Tapolca Basin, and the monadnocks of basaltic cap emerged as islands. The Kisbalaton (Little Balaton) of today and the marsh in Somogy County also were flooded. Later in the course of the Holocene epoch the lake's water level decreased. Its margins, the Tapolca Basin and the Kisbalaton separated, and the marshes of Somogy were separated by barrierbeaches. In this way Lake Balaton came to have its present shape.

Summer around Lake Balaton lasts from the end of May till the middle of September. The highest summer temperature is 30 to $35^{\circ} \mathrm{C}\left(86\right.$ to $\left.95^{\circ} \mathrm{F}\right)$. but these temperatures occur mostly in the eastern part. The attendant water temperature is 26 to $28^{\circ} \mathrm{C}\left(79\right.$ to $\left.82^{\circ} \mathrm{F}\right)$, and the water is warmer than the air at night. The daily variation of water temperature seldom exceeds $2^{\circ} \mathrm{C}\left(4^{\circ} \mathrm{F}\right)$. The water is warmest in strong sunshine at 4 a.clock p.m.

The microclimatic conditions of the lake are very favourably affected by the intense reflection of sunshine from the water, especially on the southern slopes of the northern shore, where the sunshine is valuable for vacationers as well as for the quality of grapes and fruit produced on the Balaton Highlands.

The prevailing northwest wind comes to the environment of Lake Balaton through the forest-clad Bakony Mountains. For this reason the air of the northern shore is dust-free and clean. The winds generate three types of water movement in the lake: waves, currents and swinging of water.

A storm on Lake Balaton is a phenomenon of weird beauty, yet highly dangerous. On an average there are 15 stormy days per year in the Bala- 
ton region. In exceptional cases the storms can attain gale force. The air stream suddenly diving down from above the Bakony Mountains causes a rapid temperature drop, the sky is overcast in a few minutes, and a stormy wind tears across the lake and whips up the smooth water with great force.

A view no less interesting is Lake Balaton in the winter. The shallow lake freezes almost every year. The shallower western basin freezes first. but the complete freezing of the entire lake may take weeks if the cold is not too intense. The ice floes along the beaches do not remain undisturbed for long as strong winds usually break up the thin ice sheets, forming huge barriers of them on the beach. Later on when the weather turns colder thicker sheets of ice are formed. The ice grows to a thickness of 20 to $25 \mathrm{~cm}$. on the average, but thicknesses up to $75 \mathrm{~cm}$. have occurred.

One quarter of Lake Fertö, whose average surface is $322 \mathrm{sq} . \mathrm{km}$. (125 sq. mi.), belongs to Hungary. Evaporation, changes in the ground water level, and climatic variations is general, exercise a powerful influence on the water level. The depth of water is, even under the most favourable conditions, not above 1.5 metres ( $5 \mathrm{ft}$.) but generally under 1 metre. Greater decreases in the water level periodically drain large parts of the flat shores. The high sulphate content of the clay in the lake bed, however, renders the areas thus freed unsuitable for tilling. The water level changes are connected to significant fluctuations in temperature. In winter the lake often freezes to the bottom so that it is not suitable for fish breeding. In its present marshy condition it cannot even satisfy the water sport and recreation requirements of the neighbouring towns. Until now the lake has been of no use except for the harvesting of reeds growing in a wide belt all around it.

Hungary's third lake is Lake Velence. Presently its surface is $26 \mathrm{sq} . \mathrm{km}$. (10 sq. mi.); however, not so long ago it included extensive marshes to the southwest as well. In its present condition only half of the lake has a free surface; the other half is covered with reeds. The present water depth of 1 to 2 metres ( 3 to $6 \mathrm{ft}$.) is being maintained by human effort. The flat basin has been considerably silted up by the tributary streams. The influx from the catchment area, some $600 \mathrm{sq} . \mathrm{km}$. (230 sq. mi.), would not accumulate here but would run off to the southwest were it not prevented from doing so by sluices. The lake is especially suited to fishing, particularly angling. Its shallow water, which warms up considerably in summer, would make is a Mecca for bathers if it had sandy beaches. Because of its proximity to Budapest $(50 \mathrm{~km}$. or $30 \mathrm{mi}$.) it attracts big crowds nevertheless. There are some popular weekend resorts along the shore of the lake.

According to the cadaster of the VITUKI (Scientific Research Institute for Water Conservancy) Hungary has about 1,200 standing waters having a water surface greater than 0.5 hectare, with a total surface of 900 sq. 
$\mathrm{km}$. of which the three large lakes comprise more than $700 \mathrm{sq} . \mathrm{km}$. According to their origin these standing waters are natural, back-waters, and artificial lakes.

The once so famous Hungarian marshlands now exist only on old maps. As a result of the flood control projects carried out in the late 1800's, most of them had disappeared by the turn of the century. Their former locations now are only indicated by the smooth relief of the former beds, the willow and poplar groves left on the ancient banks, and the meadow and marsh clay and patches of alkali soil.

One of the many consequences of the large scale flood control and river conservation projects was that in addition to the standing waters, their rich flora and fauna also have disappeared. The country, which not so long ago was so rich in water plants and animals and especially in water-fowl, has now reached a point where it is endeavouring to save some remains of untouched nature by establishing nature reserves in a few areas.

The most famous nature reserves offer sanctuary to some particularly important groups of plants or animals which are veritable relics of a former state of nature. Lake Feher in the neighbourhood of Szeged, and the Little Balaton at the western end of Lake Balaton, offer a safe home for rare water and wading birds. Besides the innumerable varieties of heron, there are among the surviving species redshanks (Finga totanus), great white heron (Egretta alba), black-winged stilt (Himantopus himantopus), avocet (Recurvirostra avosetta), marsh snipe, cormorants, greater and lesser godwits, sandpipers, and many other waterfowl which were once common in much wider areas. Another important function of these bird sanctuaries is that, since they are in the line of the autumn and spring migrations, they offer good resting places to Northern and Eastern European species which fly over Hungary to avoid the natural barrier of the Alps.

\section{BIBLIOGRAPHY}

Bogárdi, J. (1955). A hordalékmozgás elmélete (Theory of the alluvial deposit movement). - Budapest: Akadémiai Kiadó, p 574.

Goda, L. ed. (1965). Magyarország vizvidékeinek hidrológiai viszonyai (Hydrographical conditions of the catchment areas of Hungary). - Budapest: VIKUTI. p 138.

Kitaibel, P. (1829). Hidrographia Hungariae Vol. 1-2. - Pest: Trattner, p 316, 408.

Lászlöffy, W. (1932). A Tisza-völgy (The Tisza Valley). - Vizügyi Közlemènyek, 2, Vol. 14, pp 108-142.

Lászlóffy, W. (1934). A Magyar Duna vizjárása (Water regime of the Hungarian Danube reach). - Vizügyi Közlöny, 1, Vol, 16, pp 26-54. 
Magyarország Hidrológiai Atlasza (Hydrological Atlas of Hungary). Budapest: VITUKI, Series I: Folyöink vizgyújtôje (Catchment area of our rivers). 1. A Zagrva (The Zagyva), 2. A Sajó (The Sajö), 4. A Mosoni-Dunaág (The Moson Danube Branch), 5. A Felsó-Tisza (The Upper Tisza), 6. A Körösök (The Körōs-es), 7. A Tisza (The Tisza), 8. Az Ipoly (The Ipoly), 9. A Duna (The Danube), 10. A Drava (The Drava). Series II. Hidrometeorológiai adatok (Hydrometeorological data), 1. Csapadekviszonyok (Precipitation conditions), 2. Hómérsékleti és párolgási viszonyok (Thermal and evaporation conditions). 3. A Vizgrūjtók átlagos csapadéka (Average precipitation of the catchment areas). Series III. Data of water regime. 1. Jellemzō vízállasok (Characteristic waterlevels), 2. Árvizi adatok (Flood data), 3. Folyóink jégviszonyai (lceing conditions of our rivers). Series IV. Magyarország állóvizei (Standing waters of Hungary. 1. Magyarország állóvizeinek katasztere (Codaster of the standing waters of Hungary), 2. Magyarország vizenyós területeinek katasztere (Cadaster of the humid regions of Hungary). - (1952-1966).

Magyararszág vizkészlete (Water resources of Hungary). Budapest: VITUKI. 1. Mennyiségi számbavetel (Quantitative recording), 2. Vizfolyásaink minốségi számbavétele (Qualitative recording of our streams). 3. Viztározasi lehetöségek (Water stocking possibilities), 4. Minöségi szảmbavètel. Felszín alatti vizek (Qualitative recording. Ground-water resources). - (1954-1961).

Puskás, T. ed. (1967). Magyarország felszíni vizei (Surface waters of Hungary). - Budapest: VITUKI, P 126.

Rónai, A. (1956). A magyar medencék talajvize, az országos talajviz térképezố munka eredmenye (Ground-water of Hungarian basins, results of the national ground-water mapping). - MÁFI évk. Vol. 46, p 245.

Schmidt. E. R. ed. (1961). Magyarország vizfoldtani atlasza (Hydrogeological atlas of Hungary). - Budapest: MAFI, p 73.

Schulhof, O. ed. (1957). Magyarország ásvány- és gyógyvizei (Mineral and medicinal waters of Hungary). - Budapest: Akadémiai Kiadó, p 973.

Somogyi, S. (1964). Geographical effects of flood control and river regulations in Hungary. - Hungarian Geographical and Cartographical Studies, Budapest: IGU Hungarian National Committee, pp 37-57.

Szesztay, K. (1964). Magyarország öntözōviz szükséglete és a Kárpátmedence vizháztartása (Irrigating water demand of Hungary and water balance of the Carpathian Basin). VITUKI 1961. évi beszámoló, pp 274-287.

Tóry, K. (1952). A Duna és szabályozása (The Danube and its regulation). Budapest: Akadémiai Kiadó, p 454. 



\section{THE NATURAL VEGETATION OF HUNGARY}

M. PECSI - P. JAKUCS

In a given land, the development of the vegetation depends on the natural conditions and requires thousands of years to evolve. As a result of the evolution of human civilization, and especially of the industrial revolution of the last fifty years, the transformation of the lands has become more and more rapid, and this process has either transformed the natural vegetation or destroyed it entirely. A knowledge of the natural vegetation is in the fundamental interests of every country. Twenty-seven to thirty percent of the surface of Hungary is covered by natural, or slightly transformed vegetation which includes forests, grasses, aquatic and marshy vegetation, etc. Because of the location of the country in Europe, an extremely varied vegetation mosaic evolved.

\section{The Evolution of the Natural Vegetation}

The climatic changes in Central Europe during the Tertiary period may be deduced from the remains of the Tertiary flora which show that a tropical climate existed at the beginning of that period. Tropical plants such as Nipa palm,* whose nearest relatives are now native to Malaya, were found in Hungary.

Following the middle of the Tertiary period the climate in Hungary and in all of Central Europe gradually became cooler. The tropical plants began to disappear and substropical plants first began to take their place; then the plants of the temperate latitudes began to predominate. As the tropical forests died out, laurel-leaved and deciduous mixed forests spread over ever larger areas. The Middle Tertiary layers of the Northern Mountains have, for instance, yielded not only tropical ferns and coniferous trees, but also leaves of evergreen oak, fig and cinnamon. The organic deposits of the Miocene epoch which formed the large quantities of brown coal were largely composed of swamp cypresses (Taxodium).

Towards the end of the Tertiary period (in the Pliocene epoch) the slow cooling of the climate continued. The forests consisted more and more of associations of deciduous trees, but tropical and substropical elements also persisted. The late Pliocene flora, so rich in varieties, was destroyed

* Its fruits were found in lower Tertiary deposits, in Hungary. 
and driven out of Central Europe by the sudden change in climate and by the repeated glacial ages which marked the beginning of the Quaternary period.

Some of the remnants of the late Tertiary flora - e.g., the berch (Fagus silvatica), the mountain maple (Acer pseudoplatanus), the water caltrop (Trapa natans), etc. - support the conclusion that the flora of the preglacial period was similar to the present flora.

During the Quaternary period (the time of the glacials succeeded one another four times), the vast ice cover extending over the greater part of Northern Europe was jammed in the northern foreground of the Carpathians. Hungary was comparatively far from the ice-covered area in the periglacial zone. The characteristic landscape in the immediate vicinity of the glaciated area was one resembling the present Arctic tundra. In Hungary loess steppes speckled here and there with groves were dominant in the cold, extreme continental climate. Near the river-beds in the plains and hills and on the margins of the better protected areas, sandy and mossy fens, as well as groups of cembra pine and larch interspersed with shrubs of dwarf fir relieved the monotony of the steppes. The Hungarian Mountains belonged to the taiga forest zone.

In the interglacial ages the climate must have been somewhat like the present one with moderate precipitation. Evidence for this conclusion is provided by the remnants of deciduous trees discovered in the hearths of primeval man who had made his appearance by the Quaternary. The most frequent finds of deciduous trees have been lime, oak and maple.

During the four successive periods of large-scale glaciation, the xerothermous part of the flora which was less able to tolerate extremes either receded to the south, became extinct, or vegetated in the mountains where a more favourable microclimate existed. The repeated withdrawal of the inland ice over Northern Europe towards the Arctic resulted in several revivals of the xerothermous flora which had been forced south. This repeated north-to-south movement of the flora was greatly influenced in Central Europe by the relief, and in particular by the mountain chains of east-west strike. The line of the Alps and Carpathians largely prevented the spreading of the plants. As a result, many northern plant species could not traverse into the Carpathian Basin. Naturally, each successive glaciation decimated the migrating species. The richly varied flora of the late Tertiary period was, therefore, considerably impoverished during the lce Age.

In the Holocene epoch the climate became increasingly warmer, but the transition was uneven. Nevertheless, the plant associations, and the changes of their dominating species closely followed the comparatively weaker climate changes. Fairly accurate information on the most recent 
developments of the flora may be drawn from an analysis of pollen which is well preserved under anaerobic conditions in the Holocene swamps and aqueous sediments.

The first layers deposited after the last glaciation contain the pollen of coniferous trees, and later layers show evidence of birch and willow trees. This period is called by botanists the pine-birch stage. The climate still must have been fairly cool during this period, and it must have been similar to a stage between the taiga and the forest steppe. The xerothermous trees had not yet migrated back from the south. In the overlaying layers we suddenly find abundant pollen of such xerothermous plants as the hazel, oak, beech, elm and ash. This deposit originated during the period of the dominance of the hazel (Corylus), between about 8000 and 5000 B.C., and suggests that the climate must have been drier and warmer than before and of an extreme continental nature. During this time the zonal vegetation of Hungary's Great Plain was like that of the SouthRussian steppes. In the next 2,500 years the hazel was replaced by closed, oak mixed forests. This warmer and more humid period saw the culmination of the influx of Mediterranean elements, and in this period the transformation of the steppes to forest steppes began. The dominance of the oak coincided with the spread of Neolithis culture in Hungary. With the weakening of the continental character of the climate, and with the gradual cooling and the more abundant precipitation, the monocracy of oak was challenged by the mass immigration of the beech. The first half of the beech stage was a period of some 1,500 years and corresponded to the Bronze Age in the history of civilization. After the Pleistocene epoch, this was the period when Hungary was most extensively covered with forests. Beech penetrated right down to the margins of the Great Plain which was covered by groves of oak and by forest steppe, interspersed with extensive swamps and flood plains.

The last stage of vegetation development - the second part of'the beech stage - was the period when the present pattern of mixed natural and secondary vegetation evolved.

Since the present climate of Hungary is a transitional, changeable type lying at the zone of contact between the main European climatic areas, her flora includes Oceanic, Mediterranean, and also Continental elements. After the passage of the Pleistocene epoch the floral elements of these climatic types migrated into the basin of the Middle Danube, through the valleys traversing the Carpathians.

The richness of the Hungarian flora is, to some extent, due to the facts that this country was never covered entirely by ice, and that numerous Tertiary and Pleistocene species threatened with extinction or actually 
dying out found refuge in the Middle Danube Basin surrounded by its wreath of mountains.

Since the beginning of recorded history the changes in the Hungarian flora have been more and more closely connected with the intervention of the human society. For many centuries this intervention took place at the expense of the flora but at the present time it is taking place with careful consideration to favour the development of the flora which serves human needs.

\section{The Phytogeography of Hungary}

The flora of Hungary belongs to the floral region of Central Europe which is directly contiguous to: the Subarctic region characterized by cool summers, cold winters, and moist climate; the Pontain, characterized by a hot, dry climate with cold winters and with steppe-like features; and the warm-temperate, and somewhat humid Mediterranean floral area. Due to its geographical situation in the territory of the Pannonian floral province. the constituent species of the Western and Central European deciduous forests are combined with the floral elements of the South-Russian steppes and of the Mediterranean Sea.

The greater part of Hungary belongs to the Pannonian floral province. It contains five floral zones: the Great Plain with the Little Plain (Eupannonicum), the Northern Mountains (Matricum), the Transdanubian Mountains (Bakonyicum). Southern Transdanubia (Praeillyricum), and Western Transdanubia (Praenoricum).

\section{The Plant Associations of Hungary}

The Hungarian flora with its rich variety of species reflects the origin of the vegetation, its development, and its conmections with other zones. A wealth of species make the Hungarian vegetation interesting and varied, but nevertheless it is not the floral elements in themselves that give the Hungarian landscape its particular aspect. The best way to characterize the vegetation as part of the landscape is to describe the plant associations.

The floral association is the constant and recurring entirety of the plant species, occurring in a determined and rather constant ratio, with determined environmental demands and characteristic production of organic matter. The name of the plant association is given by the prevailing or characteristic species. In the association there can be mosses, soft stem 
plants, sub-shroubs, shrubs and trees. In the plant associations of superior organization more coexisting plant species can be found. Plant associations are developing, changing, and forming; this course of change towards the more organized and developed level is called succession. The dense network of the reed-grass flora which establishes itself in open water, for instance, gradually fills up the lake bottom and eventually it will become suitable for the establishment of the plants which are rooted in the lake bottom, for example, reed, bulrush and sedge. These plants continue the work of filling up the lake and in the margins of the original water surface more places become suitable for the development of marshland. This process prepares soil suitable for the establishment of certain kinds of trees (alder, willow, ash and birch). In such a way the plant association of the fenwood appears as the last stage in the succession of silting.

The regional appearance of the Hungarian plant cover can be best characterized by plant associations of different development and complexity. The plant associations will be discussed in order from the simplest to the most complex, because this order shows the evolution of the Hungarian vegetation cover.

In Hungary the different plant associations belong to two phytogeographical zones: the deciduous forest and forest steppe zones. However, since the climate of the country is of a transitional character between the continental and the oceanic climatic areas, the two phytogeographic zones also often are of a transitional character and sharp lines did not form everywhere. The Great Plain, the Little Plain and the Mezôföld Plain - the greater part of the country - were, in their natural state, forest steppes belonging to the belt of pedunculate oak (Quercus robur): now they are covered by secondary meadows. A large part of the Hungarian Mountains and of the Transdanubian Hilly Region belong to the deciduous forest zone (Figure 1).

\section{THE FOREST STEPPE ZONE}

\section{Aquatic and Flood Plain Plant Associations}

Even in the middle of the last century before flood control was initiated there were very extensive flood areas and marshes along the Danube, the Tisza, and their tributaries. All over the undrained swamps, the wide flood plains, and the inland waters there was a very rich aquatic vegetation. In the Little Plain and in the Great Plain, the cut-off channels and 


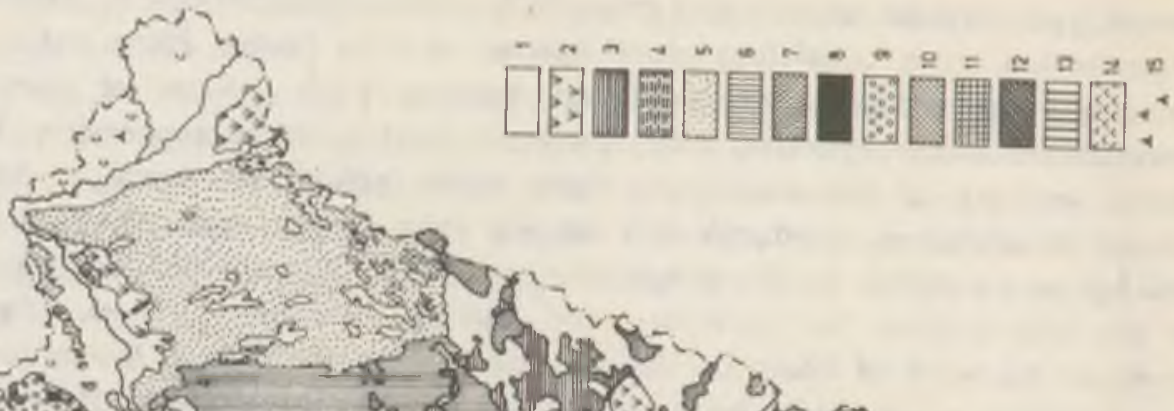

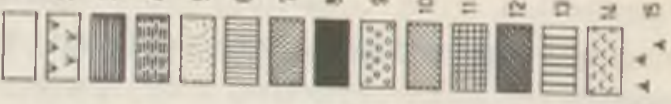

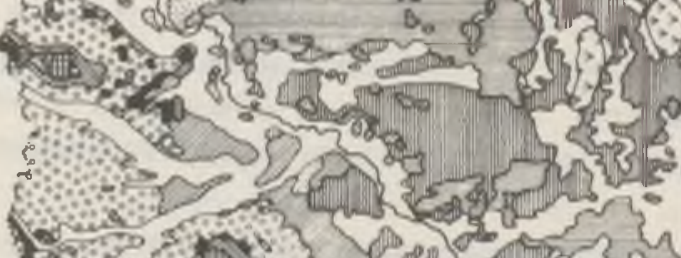

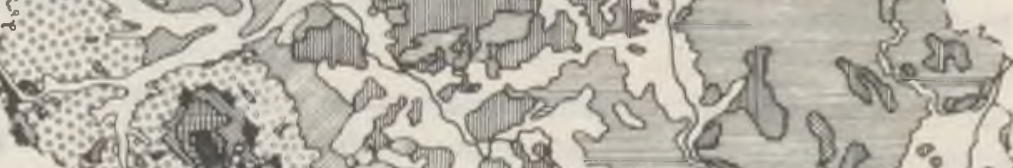

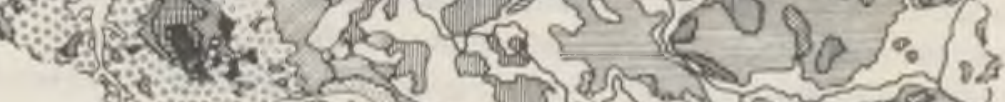

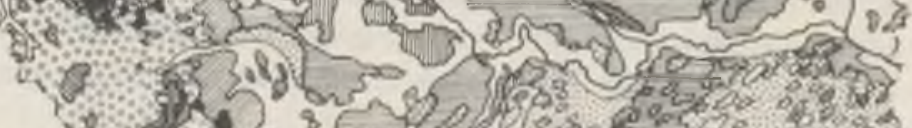

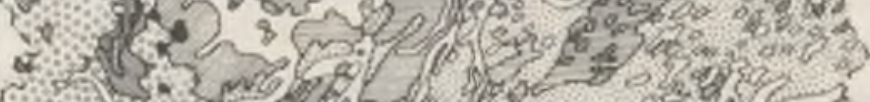
4.

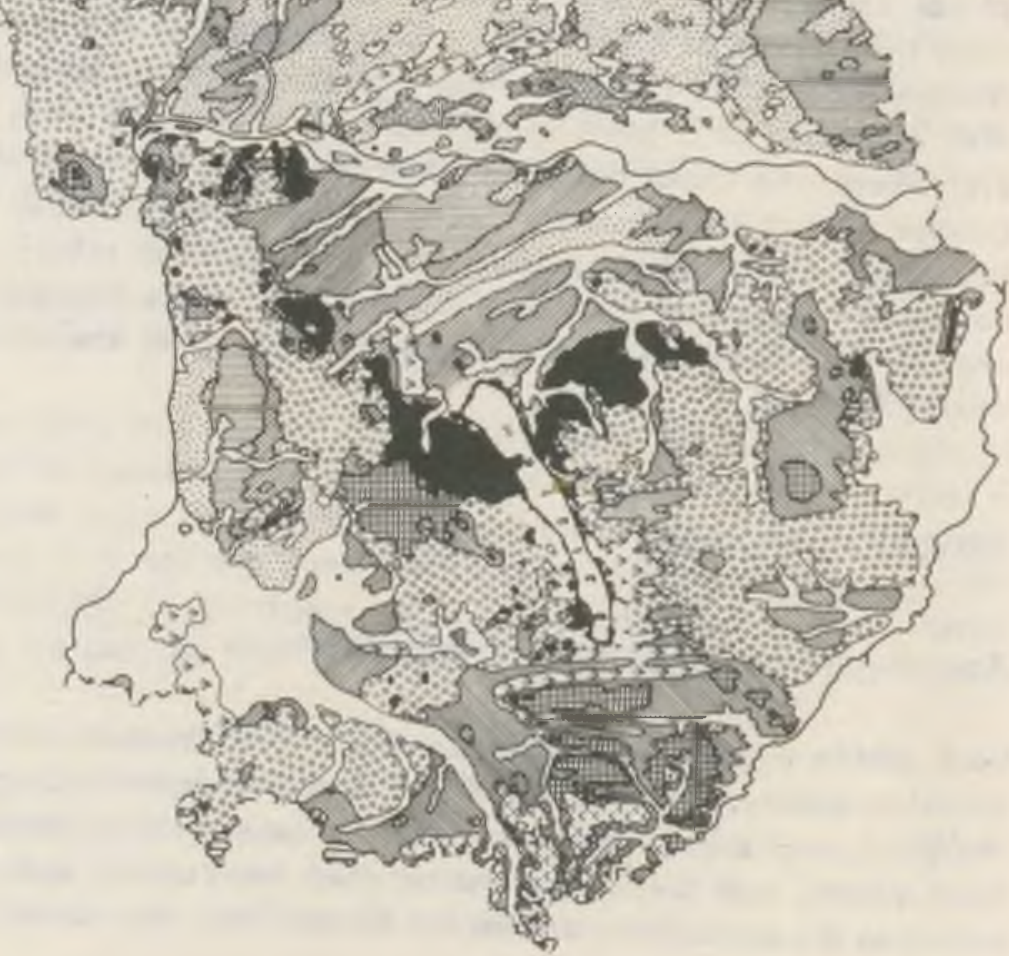


swamps of the Danube, of the Tisza, and of their tributaries were adjacent to immense alluvial and swamp forests. In the bays of the southern shore of Lake Balaton and in the vicinity of Lake Velence and Lake Fertö there were inpenetrable marches. Only fragments of these marshy or swampy lands, remained, but they neverthe!ess are very characteristic of the Hungarian flatland scene.

\section{Aquatic-marshy Associatons}

The nearshore areas of standing or sluggish waters are densely populated by the simplest associations of floating water grass whose dominant members are the duckweeds (Lemna minor and Lemna gibba), the small water fern and the floating moss (Salvinia natans).

The floating water grass gives way to the association of large water grasses (Potamion) which are rooted in the bottom of the standing or sluggish waters. These plants are of fully underwater habit, and at the most they float their flowers and leaves on the water's surface. These plants are extremely varied and rich in beautiful forms. One of the most beautiful flowers is the water buttercup (Ranunculus aquatilis) whose tiny white flowers practically cover the entire surface of some small streams, irrigation canals of rice fields, and swamp waters. An interesting member of the Potamion water grass associations is the water caltrop (Trapa natans) which is common in the swamps of the Danube and the Tisza and particularly in the Balaton district and on the flood areas of the rivers of the Little Plain. The most beautiful of the large water grasses of Hungary is the white water lily (Nymphea alba). This plant, with its flowers and round, shiny leaves, forms rank colonies over the shallower stagnant waters, especially in back waters and oxbows where it completely covers the surface.

The mass of water grasses, fastening the mud of floods, gradually accelerates the silting of the lakes and water courses, and slowly gives way

Fig. 1. Natural vegetation recontructed (after B. Zoblyomi) $-1=$ grove forests in the flood plains, swamps (also bogs between dunes and in lowland meadows); 2 = swamps and swamp forests: 3 = solonetz vegetation (formerly and partly a flood plain vegetation): $4=$ solonchak vegetation; $5=$ oak woods on sandy ground, sandy steppe: $6=$ loess steppe with shrub, with spots of oak woods on loess and on alkali soils; $7=$ oak woods with tartar maple on loess and tartar maple-oak woods on alkali soil ("szik" soil); $8=$ hairy oak forest, shrub forests. rock-lawns, slope with steppe-type grass vegetation; $9=$ acidophilus oak forests; $10=$ montane hornbeam-oak forest; $11=$ submontane beech forest: 12 = montane beech forest: 13 = oak forest on acidic soil: $14=$ scotch pine - oak forest and Silver-Fir-Spruce forest; $15=$ transitory and peat-moss bogs 
to the highly organized plant associations. As the silting progresses, the place of the water grass is taken by the reeds (Scirpo-Phragmitetum), and with further water level decreases appear the tall sedges (Magnocaricion) and the plant associations of the swampy meadow (Agrostion albae), the shrub-willows and the forest associations of flood plains.

\section{Flood Plain Forest Associations}

The banks, flood plains, oxbows, and shoal islands of the Danube, Tisza, and their tributaries are lined with a silvery grey ribbon of willow and poplar groves (Saliceto-Populetum) (Figure 2). In the foliage stratum of this soft-wood association of low flood plains, the white willow (Salix alba), the crack willow (Salix fragilis) and the black poplar (Populus nigra) mingle, though the latter forms separate groups. The white willow is one of the most valuable members of the flood plain forests. Its shoots are used for basketwork and wickerwork, of which much is exported. In the shrub stratum of the association, the various species of hawthorn dominate, while in the grass zone the most frequent plant is the dewberry (Rubus caesius).

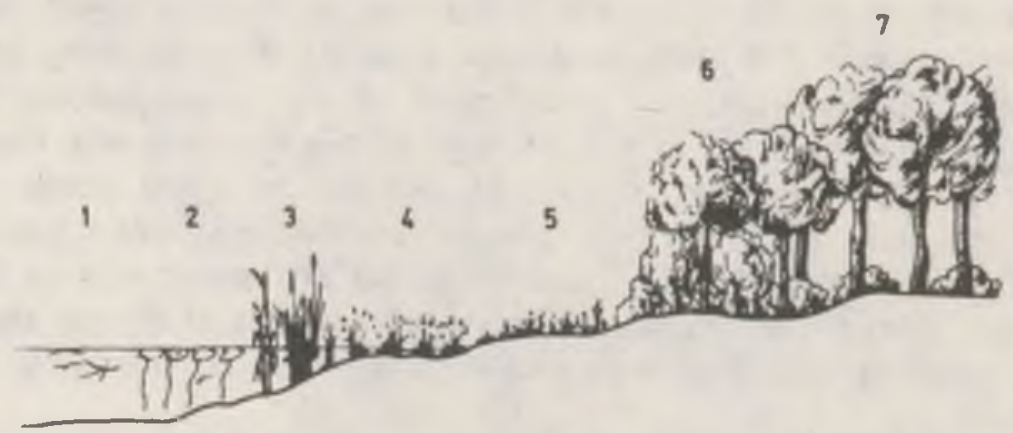

Fig. 2. Aquatic and water-side vegetation schematic profile (after P. Jakucs, 1960). $1=$ infixed reed grass: 2 = fixed reed grass; $3=$ reeds; $4=$ sedge; $5=$ swamps: $6=$ grove forests with Salix and Populus; $7=$ grove forests with Uimus, Fraxinus and Quercus

At the higher levels of the flood area, where only the larger floods carry fine sediment and silt, the succession of aquatic plant associations reaches the stage of the elm-ash-oak grove forest. This is the highest order, the socalled end climax association (Querco-Ulmetum hungaricum) of the flood plains.

At the foliage zone, this is a heterogeneous forest of hardwood trees, which yields useful timber to the Great Plain otherwise poorly supplied 
with wood. Apart from the pedunculate or ramp oak (Quercus robur), the dominant tree species are the field elm (Ulmus campestris) and the sharppointed ash (Fraxinus oxycarpa). In the shrub stratum the characteristic plants are low hawthorns, dogwoods and occasionally Tartar maples (Acer tataricum).

\section{Grass-Moor Plant Associations}

Grass-moor associations are formed in stagnant waters, in flat hollows of valious size with poor drainage, far from the flood plains, where the moving waters no longer dump their load. If it is large the moor may constitute a peculiar floral unit of its own (e.g. the Hanság, Little Balaton. etc.). The silting of the grass-moors takes place by the accumulation of the mortified plant organisms, unlike that of the flood plains which takes place mainly by mineral substances - by mud and sand.

In the middle of the moors the local shallows are sporadically inhabited by tussock and tall sedge associations. The dominant clump sedge (Carex elata) forms dense tussocks over a peat base. To traverse these areas it is necessary to jump from tussock to tussock over the water surfaces covered by marshy vegetation which in more arid years completely dries out.

The higher plant association to which the elevated tussocks give way is the damo grass-moor association formed by the fenland sedge (Caricetum davallianae) and by the large rush (Juncetum subnodulosii). This is a markedly peat-forming plant association. At higher levels which are relatively dry after drainage it gives way to the desiccating grass-moor. The dominant grass in this association is the purple moor grass (Molinia coerulea). The desiccating grass-moor no longer yields peat, but has a considerable part to play in the formation of swamp soil on top of the peat surface. Where the grass-moors are constantly reaped, this plant association becomes stable. In many places where the ancient conditions have not yet been disturbed, the succession of the grass-moor associations reaches the end associations - the moor osiers or the alder moor forest whose characteristic species are the grey sallow (Salix cinerea) and the resinous alder (Alnus glutinosa) as well as the sharp-pointed ash (Fraxinus oxycarpa). The alder moor forest is the most highly organized multilevelled (moss, grass, shrub and foliage stratum) plant association of the grass moors. This sequence of development sometimes is clearly shown by the zone-like position of the plant associations. Using knowledge of this regularity, plant associations can be systematically transformed, and development can be artificially promoted. 
The Great Plain, the Little Plain and the Mezöföld Plain in Transdanubia make up the greater part of the country's territory. Upon their higher and drier surfaces the forest steppe plant associations originally were dominant but now agriculture, for the most part, has driven them away. It is difficult to reconstruct in detail the original condition. It is only in places, especially on areas of alkali soil and aeolian sand dunes less suited for agriculture, that the original plant associations have survived. Upon the chernozem soil of the highly fertile loess slopes the plant association of the original loess steppes has, in the course of hundreds of years of agriculture, become almost completely extinct. The original picture has been reconstructed only recently by the latest scientific research.

\section{Plant Associations of Alkali Soils}

Of the natural plant associations, those of the alkali soils have best preserved their original state, but these associations exist only in areas of relatively small size. Their present large expanses are partly secondary. With the decrease in the ground water level caused by the river regulation and the drainage of the former alkaline lakes and marshes, alkali soils were formed in ever larger areas and became colonized by halophytic plants. The plant associations of the alkaline flats vary according to the water supply and soda content of the soil.

Where the soil is not too alkaline there are extensive alkaline pastures. Their characteristic grass is the sodaic fescue (Festuca pseudovina), associated with numerous other plants of the alkali soils. In the more intensely alkaline areas the sodaic fescue associations become sparser and gradually give way to more open grass associations characterized by sagebrush (Artemisia maritima). On the most alkaline areas which are damp in spring but become completely dry later another grass - the salt meadow grass (Puccinellia limosa) - becomes predominant. It is accompanied by masses of wild camomile (Matricaria chamomilla) and other plants. The small wild camomile, very suitable for herb-tea, is the most valuable plant of the alkali soils, and it is exported in large quantities.

The poorest plant association of the alkaline flats is that of Camphorosma ovata. The site of this association is dry, barren and dazzlingly white, but in autumn it is coloured red by the Camphorosma ovata.

Now that the ecology of the plant associations of alkali soils is known. biological methods (ie., soil reclamation without breaking up the grassy surface) occupy an increasingly prominent place in the struggle against alkali soils. 
A large part of the forest steppes of the Great Plain is occupied by windblown sand dunes. They are most extensive between the Danube and the Tisza and in the Nyirség district. The micro-morphological aspect of these sand areas is very varied. Dunes and flat depressions scooped out by the wind alternate frequently, and therefore the ground water level also is very changeable. The almost semi-desert plant associations of the still shifting sand are found in the immediate neighbourhood of the closed oak forests of the forest steppe zone.

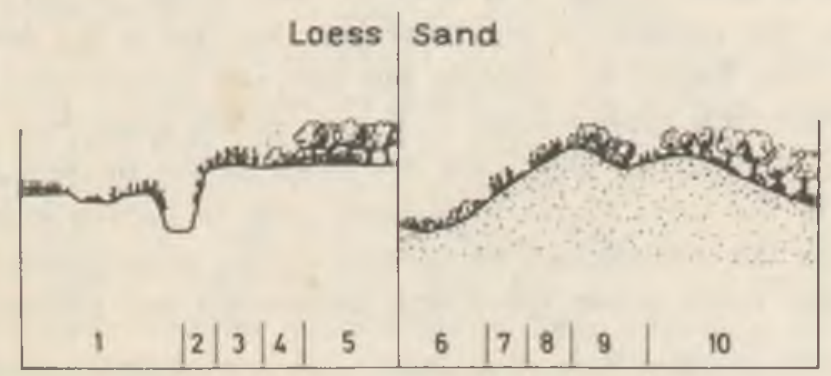

Fig. 3. Steppe vegetation schematic prohile (after P. Jakucs, 1960). $-1=$ vegetation on alkali soil ("szik" soil): 2 = Agropyro-Kochietum on loess; $3=$ loess steppe; $4=$ shrub with Amygdalus nana; $5=$ oak woods with lartar maple; $6=$ Salicetum rosmarinifoliae; $7=$ sandy steppe with Festuca vaginata; $8=$ sandy steppe with Festuca sulcata; $9=$ sparse oak woods on sandy soil; $10=$ canopied ook forests on sandy soil. $1-5=$ loess;

$$
6-10=\text { sand }
$$

The pioneers on the still freely shifting sands are brome grass (Bromus tectorum) and wood rye (Secale silvestre). The grass of the sandy steppe is of very loose texture. Lower order plants, mosses, and lichen grow on the bare sand. The half-bound sand has a higher stage of grass development. On the dune slopes the Hungarian fescue (Festuca vaginata) plant association is the most characteristic. Together with it grows the Ephedra dastachya, a plant of eastern origin.

In the next phase of succession the closed steppe meadow is formed. The dominant grass here is the striated fescue (Festuca sulcata), but some species of the open sandy grasses still occur. In the depressions among the dunes the most characteristic plant association of the sandy parts of the steppe is the poplar-juniper (Junipero-Populetum albae). The white poplar (Populus alba) with its deep roots penetrates into the sand steppes or closed grasslands as a pioneer.

The final plant association in the Great Plain consists of two types of oak woods. The first, drier and more open, is the lowland oak (Festuco- 
Quercetum roboris); the second, occurring on a higher ground water level. is the oak with lily of the valley (Convallario-Quercetum roboris). This type also is often transitional to the elm-ash-oak grove forest. At the foliaga level of the first the pedunculate oak is the monarch. The oaks of the sandy country on the Great Plain are very important for they bind the sand and ease the shortage of timber (Figure 3).

The Vegetation of the Loess

The fertile loess cover occupies a relatively very large territory in Hungary. The extensive, flat surfaces of the loess plateaus rise a few feet above the flood areas. Man began to cultivate the rich soil (chernozem) at an early period in history (the Bronze Age), and now nearly every inch of this land is utilized for agriculture. Thus, only the relics of the ancient steppe plant associations of the loess banks have been able to survive in a few places that have been left undisturbed for centuries (e.g., strips along boundaries). In these places there grows the Volga pheasant's eye (Adonis volgensis).

Research has shown that the loess plant associations of the Great Plain are most closely akin to the plant associations of the East European forest steppe zones. The plants of the Hungarian steppes include several endemic species and numerous immigrants from the South Russian plains. In its natural state the Great Plain was a forest steppe belonging to the pedunculate oak belt: now it is a cultivated steppe. The initial plant association on it was that of the loess steppe with an almost completely closed grass stratum. The grasses include, among other plants, the striated fescue (Festuca sulcata) and the curly needlegrass (Stipa capillata).

At one time the shrub association of dwarf almonds (Amygdaletum nanae) was very widespread at the contact of loess steppes and forest steppes. The final plant association on the loess plateaus of the plain was loess steppe forest of tartar maple and oak (Aceri tartarico-Quercetum). At the foliage stratum here the pedunculate oak, the hairy oak, occasionally the turkey oak, the field elm and the tartar maple (Quercus robur, Quercus pubescens, Quercus cerris, Ulmus campestris, Acer tataricum) mingled in a characteristic manner. This type of forest, once widespread in the Great Plain, is the equivalent of the East European forest steppe plant associations and is their westernmost extension. 


\section{The Forest Associations of Mountains of Medium Elevation and Hills}

The mountains lower than 1,000 metres which stretch along the southwestto-northeast diagonal of the country belong to the zone of deciduous forests. Not even the tallest peaks reach the fir-wood zone. On the higher mountains, in the cooler valleys, and on the northern slopes the beech associations are dominant; while on the lower mountains, the lower stretches of the slopes, on the warmer southern slopes, and on the flat hills of the Transdanubian Hilly Region, oaks prevail.

Over the Mezozoic dolomite blocks of the Hungarian Mountains there often are barren, treeless dolomite areas. On the steeper, rocky slopes the soil cover is so thin that only the rock lawn association can gain a foothold there. The vegetation at best covers only half of the raw soil. As the soil grows thicker, the rock lawn becomes more and more dense, and species with higher requirements crop up. First the rock lawn closes completely (steppe meadow associations); then begins a shrub-like light wood interspersed with clearings, called the karst shrub forest (CotinoQuercetum and Ceraso-Quercetum). It is a plant association resembling a park and it marks the beginning of the forest zone. Its foliage is 2 to 8 metres ( 6 to 26 feet) high, with tangled branches interwined with the shrub level. This association is neither shrubs nor a true forest. The characteristics of the foliage and shrub-stratum are: the fluffy oak (Quercus pubescens), the flowery ash (Fraxinus ornus), the Hungarian fustic (Cotinus coggygria), the Prunus mahaleb, and the plumpy cornel (Cornus mas), etc.

\section{Beech Forests}

The most valuable mass supply of industrial timber is provided by the beech forests. The beech tree (Fagus silvatica) likes a cool cilmate and relatively abundant precipitation. On hills of over 600 to 900 metres $(2,000$ to 3,000 feet) it generally prospers excellently on any slope, regardless of which direction it faces. The dominant species of the beech associations (Fagetum silvaticae) is the beech, though individual ashes and mountain maples may mingle with it. The shrub stratum generally is absent and the carpet level is sparse in the tall, shandy beech forests which are almost completely closed at the foliage stratum.

The four most widespread forest associations of the Hungarian beech forests are distinguished by, and named after, their carpet plants. The 
northern, cooler slopes or higher (limestone) plateaus are favoured by the beech with woodruff (Asperula). This is the most widespread of all types. The carpet layer frequently is completely absent so that the soil is covered only by fallen leaves. The type of beech forest with Carex pilosa may evolve over any kind of bedrock and is a rapidly growing forest, yielding much timber. The most abundant and best quality timber is furnished by the beech forest with wood sorrel (Oxalis). On southern slopes with rocky soil the characteristic type is the beach forest with Melica, which grows more slowly.

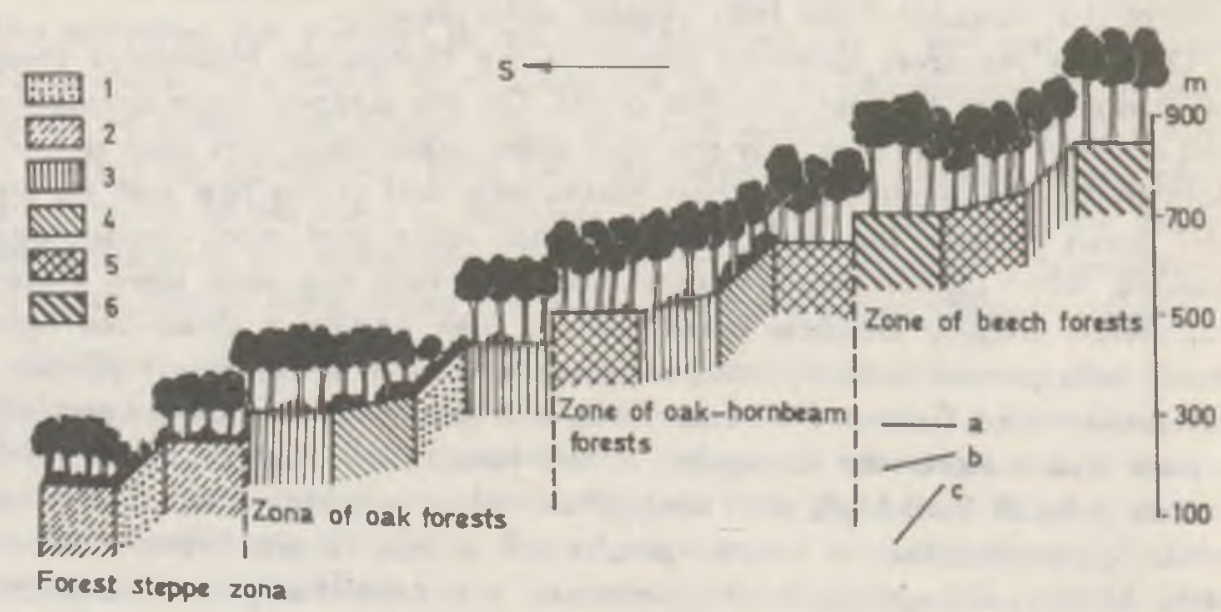

Fig. 4. Forest zones of southern slopes with different angles in the Hungarian Mountains (schematic profile). -1 steppe, shrub forest: 2 = loess ook forest: 3 = Turkey-oak sessile-oak forest; 4 = calci - and thermophilous oak forest; $5=$ hornbeam-oak forest:

$6=$ beech forest. Inclination of slopes: $a=0$ to $5^{\circ} ; b=10$ to $20^{\circ} ; c=20$ to $35^{\circ}$

\section{Oak Forests}

Upon the sunny, dry, and warm slopes of the Hungarian Mountains, and on the lower hills in Transdanubia the most characteristic growths are the various associations of oak. On the slopes of the limestone mountains the calciphile oak forest (Orno-Quercetum, Corno-Quercetum) has spread everywhere. This is the closed forest plant association accompanying the karst shrub forest association. The foliage level is composed mainly of hairy oak (Quercus pubescens), sessile oak (Quercus petraea) and turkey oak (Quercus cerris).

Very widespread over the whole of the Hungarian Mountains and the hills of Transdanubia is the Quercetum petrac re-cerris oak association 
which grows over the most varied bedrocks in clayey or sandy soil. This is a forest of great economic value and its carpet level is rich in varieties. On the slopes of the volcanic ranges of the Northern Mountains (the Börzsöny, Mátra and Zemplén Mountains) and in the western part of Transdanubia the calcifuge oak association (Genisto tinctoriae-Quercetum) has developed. In its foliage stratum the birch accompanies the sessile oak. In the western part of Transdanubia, on the gravel-covered flat ridges along the Rába and Zala Rivers, this association includes ever increasing numbers of Scotch pines (Pinus silvestris), and where the precipitation is plentiful the Scoth pine becomes dominant.

In the cooler, mesophile areas which are lower than the beech, but higher than the oak forests, the oak and hornbeam form widespread associations. This is the characteristic forest association of the hillock districts of Central Europe. In the oak and hornbeam forests the oaks are the prominent trees, and the hornbeam appears only in the second foliage layer. This type of forest is very valuable economically. In the grass carpet of these forests the early spring geophytes are characteristic, and later in the summer their place is taken by other plants.

\section{Pine Woods}

The pines which may be found sparsely scattered in the Hungarian Mountains today are not original. In the Transdanubian Dolomites the primeval barren areas and the slopes in danger of soil erosion after the felling of timber frequently were populated with black fir. These and the plantations of fir and spruce in the Northern Mountains and in the Sub-Alps are extraneous features in the deciduous forest regions of the phytogeographic equivalent of the Hungarian Mountains.

The natural vegetation of Hungary generally is rich in varieties, but the area covered by vegetation is decreasing to more and more confined areas because of the progression of the agricultural cultivation. The rare species and those varieties in danger of extinction now are carefully protected.

\section{BIBLIOGRAPHY}

Andreánszky, G. (1954). Osnövènytan (Palaeobotany). - Budapest: Akadèmiai Kiadó, p 320. Bulla, B. (1962). Magyarorszàg természeti földrajza (Physical geography of Hungary). Budapest: Tankōnyvkiadó, p 423.

Jakucs, P. (1961). Die phytozönologischen Verhältnisse der Flaumeichen-Buschwälder Südostmitteleuropas. - Budapest: Akadémiai Kiadó, p 313. (Monographie der Flaumeichen-Buschwälder). 
Jakucs, P. (1970). Magyarország rekonstruălt természetes nóvenytokarojának térkèpe (Reconstructed natural vegetation map of Hungary). - Kézirat (Manuscript).

Jakucs, P. (1971). Dynamische Verbindung der Rasen und Walder. - Budapest: in print.

Soo, R. (1945). Novenyfoldrajz (Geobotany). - Budapest: M. Term. Tud. Tars. p 205.

Soo, $R$. (1964). A magyar flóra és vegetació rendszertani - nóvényfoldrajzi kézikönyve I (Systematic geobotanical handbook of the Hungarian flora and vegetation). - Budapest: Akadèmiai Kiadó, p 589.

Zólyomi, B. (1953). Die Entwicklungsgeschichte der Vegetation Ungarns seit dem letzten Interglazial. - Acto Biol. Hung. 4, pp 367-413.

Zolyomi, B. (1957). The zonal plant associations of Hungary. - Acta Biol. Hung. Suppl. 1. pp 7-8.

Zolyomi, B. (1958). Budapest és környékének természetes nōvenytakarója (Natural plant cover of Budapest and its environment). - Budapest termeszeti kèpe. Pécsi, M., Marosi, S. and Szilard, J. eds. Budapest: Akadémiai Kiadó, pp 508-642. 


\title{
THE SOILS OF HUNGARY
}

\author{
M. PECSI-L. GOCZAN
}

Hungary's most valuable natural resource is her varied and extremely fertile soil cover. Its varied character may be attributed to the natural interaction of the landscape-forming agents discussed in the previous chapters - the bedrock, relief, climate, hydrography and the vegetation. The soil, after its formation is itself one of the land-forming agents, but its formation and local appearance are considerably influenced by the natural agents mentioned above. From the point of view of the soil formation, Hungary can be divided into two parts, which can be separated from each other on the basis of the relief: a hilly and mountainous land, and an expanded lowland. On the former, because of the higher and undulated relief forms, various forest soils usually have evolved. In the plains, as a result of the interaction of the soil-forming factors, meadow, chernozem and alkali soils and their diverse varieties may be found together.

In Hungary the relief-sculpturing and the soil-forming factors are very diverse; they may vary considerably even within a small area. For this reason the number of soil types in Hungary is greater than elsewhere in Eastern Europe. The main reason for the rich variety of soil types in a relatively small area is the intermediate character of the country's climate as well as the sum total of its varied hydrographic, geological and relief features.

Soil geographic and pedological research and mapping were, for this very reason, initiated in Hungary as early as in the last century. For a considerable time the investigations and classifications reflected a static approach. The momentary condition, physical, and chemical properties of the soil were examined. Even pedological investigations of this type were of extreme importance and resulted in a soil map of the country, on a scale of $1: 25000$.

More recent research on soil geography has applied the genetical principle to the classification of Hungarian soil types and to the elucidation of their development. This research has been done on the principles proposed by Peter Treitz and Elek Sigmond, using the outstanding achievements of Russian and Soviet peJology.

In recent years Hungarian soil scientists, Pál Stefanovits and László Szücs, have prepared the genetic soil type map of the country on a $1: 200000$ scale. Before this mapping the soils of Hungary were systematized from genetic and soil-geographic points of view. This system cate- 


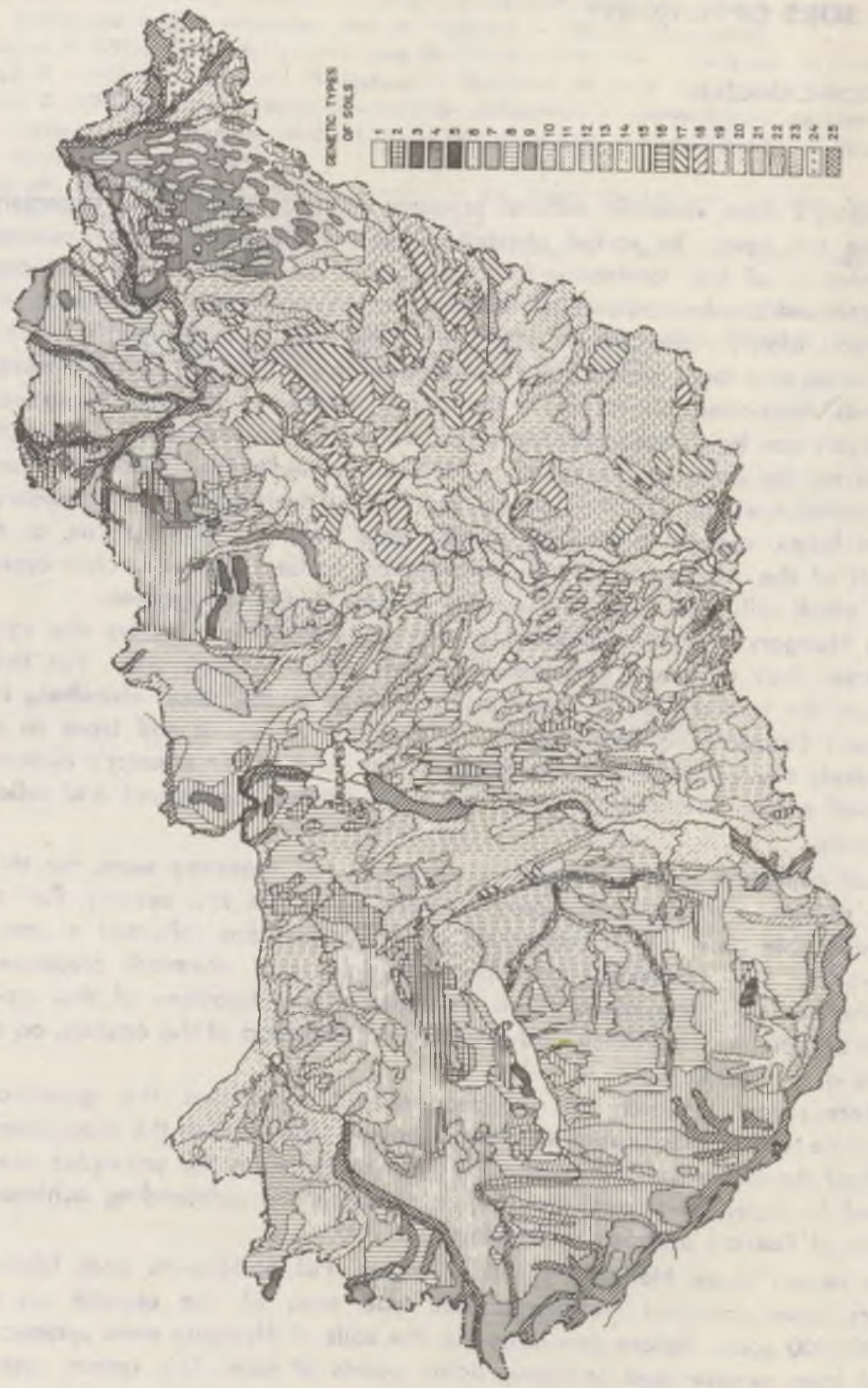


gorizes the soil types in accordance with the stage of the soil-forming processes. In compliance with this principle the following soil types are distinguished: skeletal soils, which are unformed because of different causes; lithomorphous forest soils, which reflect the peculiar soil-forming effect of the rocks; and the two main types of the brown forest soil of Central and Southeastern Europe as well as the chernozem soils, the two great climatezonal soil groups. Within the chernozem zone the following main soil types can be distinguished: the alkali soils formed in places without an outlet; the semi-hydromorphous meadow as well as the marshy and flood plain forest soils formed by the effects of the dominant influence of the capillary ground water and the hydromorphous bog soils formed as a consequence of constant ground water effect.

These types include the soils formed under the same physical, chemical and biological processes as well as under the same geographic conditions. Their classification is given in Table 1 (Stefanovits, P.-Szücs, L., 1961).

\section{The Description and Geographic Distribution of Hungarian Soil Types}

\section{SKELETAL SOILS}

The blownsand covers a vast area in the Great Plain as shown in Figure 1.1. The sands of the territory between the Danube and the Tisza originating from the Danube's area are calcareous, but those of the Tisza are of acidic character. The blownsand has neither humus content, nor structure.

The upper level (20 to $40 \mathrm{~cm}$.) of the humic sand already has become slightly humic from the effect of the flora and cultivation; but this soil too has no structure.

The alluvial soils cover a vast area. These soils are of very small humus content and are at the beginning of the process of soil formation. Before

Fig. 1. Genetic soil map of Hungary (after P. Stefanovits-L. Szücs). $-1=$ blownsand; $2=$ rendzina; 3 = erubase soil, black nyirok; $4=$ strongly acidic non-podzolic brown forest soil; $5=$ podzolic brown forest soil; $6=$ grey brown forest soil; $7=$ pseudogleyic brown forest soil ; $8=$ brown earth according to Ramann; $9=$ brown forest soil with alternating thin layers of clay substance kovárvány; $10=$ chernozem-brown forest soil; $11=$ sand of chernozem character; $12=$ chernozem with carbonate coating; $13=$ meadow chernozem; $14=$ alluvial chernozem; $15=$ solonchak; 16 = solonchak-solonetz; $17=$ meadow solonetz; 18 = meadow solonetz converting to steppe soil; $19=$ meadow soil; 20 = alluvial meadow soil; 21 = boggy meadow soil; 22 = meadow bog soil; 23 = drained and cultivated meadow bog soil; 24 = soils of marsh and alluvial forests; $25=$ recent alluvial soil 


\section{SKELETAL SOILS}

1. Stone detrital, gravelly skeletal soil

2. Parent material of humus remain

3. Blownsand soil

4. Humic sand

5. Recent alluvial soil

6. Humic alluvial soil

7. Soil deposited on slopes

\section{LITHOMORPHOUS SOILS}

8. Humus-carbonate soil

9. Rendzina

10. Erubase soil, black „nyirok"

\section{BROWN FOREST SOILS}

11. Strongly acidic non-podzolic brown forest soil

12. Podzolic brown forest soil

13. Grey brown podzolıc soil

14. Pseudogleyic brown forest soil

15. Brown forest soil with alternating thin layers of clay substance (kovárvány)

16. Brown earth

17. Chernozem-brown forest soil

\section{CHERNOZEM SOILS}

18. Chernozem with forest remnants

19. Leached chernozem

20. Chernozem with carbonate coating

21. Meadow chernozem

\section{ALKALI SOILS}

22. Solonchak

23. Solonchak-solonetz

24. Meadow solonetz

25. Meadow solonetz converting to steppe soil

26. Soil secondarily evolving into alkali soil (anthropogenic)

\section{MEADOW SOILS AND FLOOD PLAIN FOREST SOILS}

27. Meadow soil converting to steppe soil (chernozem-meadow soil)

28. Meadow soil

29. Solonetz-like meadow soil

30. Solonchak-like meadow soil

31. Boggy meadow soil

32. Alluvial meadow soil

33. Marshy and flood plain forest soit

\section{BOG SOILS}

34. Mossy bog soil

35. Meadow bog soil

36. Drained and cultivated meadow bog soil 


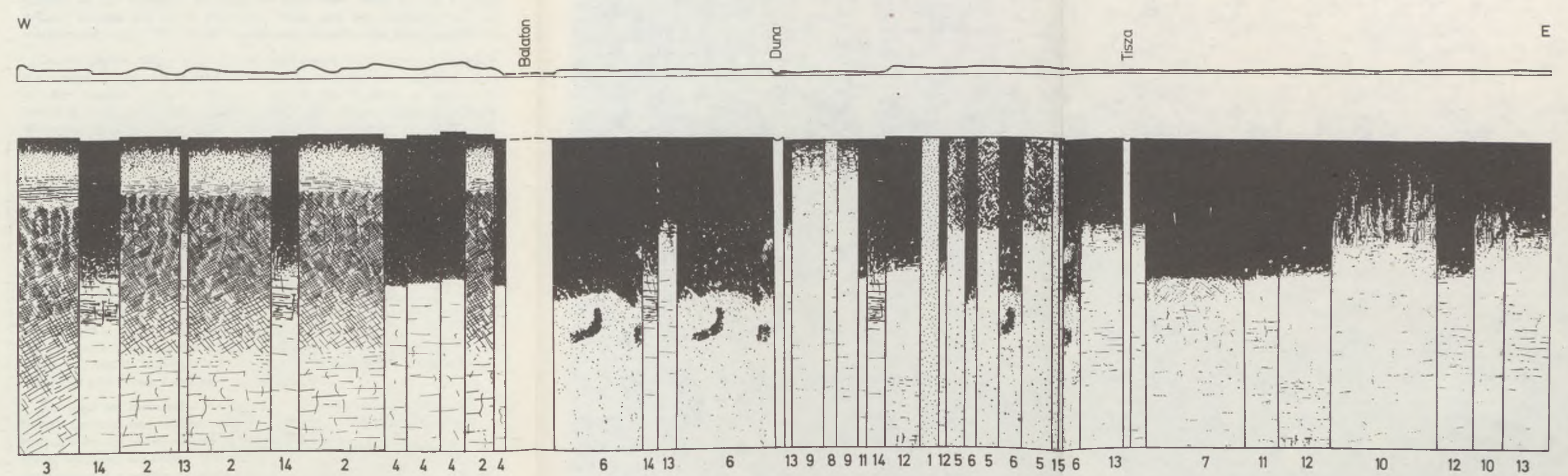

Fig. 2. Relief profile and profiles of the main genetic soil types along the 47 th latilude -1 = blownsand; $2=$ grey brown torest soil; $3=$ pseudogleyic brown forest soil with borbole cooting: 7 = meadow chernozem; $8=$ solonchak: $9=$ solonchak-soloret 10 = meadow solonetz converting to steppe soil; $11=$ meadow soil converting to solonetz soil; $12=$ meadow soil; $13=$ meadow alluvial soil; $14=$ meadow bog soil 
the regulation of the rivers in Hungary, the Danube, the Tisza and their larger tributaries, flooded regularly and spread their silty, sandy sediment ovar very broad tracts of land. The oft-repeated floods hindered the process of soil formation because the vegetation could act on a given alluvial surface only for a short time. Little time wcs available for the formation of humus. The resent alluvial soils formed under these conditions.

On the slightly higher levels of the flood plains which are rarily flooded. the process of humus formation could begin. In such a way, a humic level of small organic matter content was formed the thickness of which was only 2 to $3 \mathrm{~cm}$. These are the humic alluvial soils, which, due to the process of humus formation, are transformed into alluvial chernozem or alluvial meadow soils.

\section{LITHOMORPHOUS SOILS}

The rendzina formed in large continuous spots on the plateaus and slopes of the limestone and dolomite block-mountains of the Hungarian Mountains. This rendzina, its area is shown in Figure 1.2, has a forest soil character and is related to the chernozem soils. It forms under rock grasses and karst shrub forests, and under the hairy oaks of rich underwood. It has a high organic matter content because of its extreme water regime and its clay content is low. The contact of the humic level and the compact carbonate rock or of the silt shows a sharp transition. Its reaction is weakly basic, or neutral, and its fertility is low. It occurs independently on dolomites, and alternates with brown forest soils on limestones.

The nyirok soil depicted in Figure 1.3 is a forest soil controlled by bedrock formed on lavas and tuffs of volcanic origin, or on their broken fragments. It usually occurs under extreme soil-climate conditions, on sharp ridges and steep, southern, dry slopes. The shallow tilth and the extreme local climate produces only a weakly developed forest culture, but at the same time the volcanic detritus of high clay content promotes the formation of the luxuriant grass-vegetation. This clay, however, consists mainly of montmorillonite and due to this fact as well as to the shallow tilth it becomes extremely dry. The accumulation of large quantities of humus is the consequence of this phenomenon. This process forms black nyirok soil. Its colour is mostly black, and its reaction is slightly basic or neutral.

The yellow and red detritus which is an adobe of high clay content and has accumulated in the foothills and on the slopes of the Hungarian volcanic mountains also is called nyirok by the geologists but they consider it a detrital substance rather than a soil. 
The podzolic brown forest soil was formed under the closed forests in the areas with most abundant precipitation in the hills and in the Northern Mountains. Under the influence of copious precipitation, the eluvial horizon is 30 to $40 \mathrm{~cm}$. This soil always is pale, and frequently it is light gray or yellowish white. The humus is very thin and there is a very acid podzol top soil. The soil is coloured red-brown by the iron compounds which accumulate. This type of soil is particulary characteristic of the higher regions of the Northern Mountains (Zemplèn, Būkk, Mátra, Börzsöny Mountains), under the beech and oak forests which favour a humid, rather rainy climate and also in the pine forests of the foothills of the Alps and the hills along the border in Vas and Zala Counties (Figure 1.6).

\section{Grey brown forest soils}

Undoubtedly these soils form the greatest part of the forest soils of Hungary. In the mountains and hilly countries of Hungary where the yearly precipitation is over $650 \mathrm{~mm}$., these soils can be found everywhere except on dolomites. It is characteristic of the profile of these soils that the clay colloids flush from the eluviation level into the level of accumulation without collapsing. Their formation is favoured by the carbonate shortage, the surplus of the humidity of ground of relief and the facing to north. The structure of this soil is nutty and prismatic, and its reaction is acid (Figure 2.2). It usually is ameliorated physically as well as chemically in the course of agricultural cultivation.

\section{Brown earth, or brown forest soil according to Ramann}

According to Ramann this soil is formed on the southern, loess-covered lower slopes of the mountains of medium elevation; on the limey, loose, soil-forming rocks of the hilly countries (Figure 1.8) and on the surfaces of macro-, local- or soil-climate drier than that of the grey brown forest soils. The following properties are characteristic of the profile of these soils: an equal distribution of clay in the profile; the enrichment with the iron and aluminium oxides in the B level; the nearly acidic reaction; the great arenaceous structure in the $B$ level, and the crumbly arenaceous structure in the A level (Figure 2.4). The agricultural utilization of these types is highly efficient. They can be cultivated easily and yield rich crops with satisfactory fertilization. A variety of this soil type, the rubiginous forest soil 
forms on sandy soil-forming rock. It is worthy of note because it is relatively widespread.

In the transitional zone of the Hungarian plains facing the hilly countries and mountains the chernozem brown forest soil predominates (Figure 1.10). It is formed from the effects of the soil-climatic drying out which has occurred on the impact of the agriculture. It characteristically contains two levels: the reddish-brown accumulation level, rich in iron and aluminium oxides; and the humic level of organic-mineral complex, saturated with calcium. The humic level is of crumbly structure, its reaction is neutral or sometimes weakly basic, and it can be characterized by chernozemdynamic properties. Its greatest uninterrupted expanse formed in the foothills of the Mátra and Bükk Mountains, but it also is frequent on the margins of the Little Plain. It is a cropland of high quality.

\section{STEPPE SOILS (CHERNOZEM SOILS)}

The chernozem soil with carbonate coating of the Great Plain is one of the most fertile types of the steppe soils (Figure 1.2). It has evolved over great expanses of lowland loess banks and on the loess of varying thickness in the Mezöfold Plain. These soils also have appeared in smaller patches on other bedrocks, under the grassy and papilionaceous vegetation. The chernozem has an excellent crumbly structure, and its humus layer of up to $150 \mathrm{~cm}$. in thickness has gradual transition to the subsoil (Figure 2.6). It is relatively rich in humus and brown or brownish-black in colour. Its $\mathrm{pH}$ is mildly basic or neutral. The fertility of the chernozem soil depends mainly on the thickness of the humus layer.

When the capillary zone of the ground water repeatedly reaches the section of chernozem, the meadow chernozem (Figure 1.13 \& Figure 2.7) the most fertile soil type of the country is formed.

\section{ALKALI SOILS}

Alkali soils in the Great Plain are associated with steppe and meadow soils at levels somewhat lower than the former and higher than the latter. In the shallow depressions without an outlet which are of high salt concentration, alkali soils always form. These soils are classified according to their structure and saline content into the following types: lime-free alkali (solonetz), limey alkali (solonchaky-solonetz, Figure 2.9) and limey-salty (solonchak, Figure 2.8). These differences finally depend on the distance above the salty ground water causing the accumulation of alkaline deposit. In case of the solonetz type the ground water level is always deeper than 
one metre; in case of solonchak soils it is at least intermittently higher than half a metre. The solonchaky-solonetz soil is a transitional type; it either becomes alkaline or to the eluviation of the surface.

Lime-free alkali (solonetz) soils are most widespread east of the Tisza River (Figure 1.17-18). They are of massive-columnar structure. In the soil profile of this type calcium carbonate can be found only to a depth of half a metre or a little more. The humus content is low, and the fertility can be improved by treatment with lime mud. The solonchaky-solonetz soils are limey, or sometimes salty, alkali soils of columnar structure. In their profile, the easily soluble carbonate of calcium is somewhat nearer the surface, and consequently the lime treatment of the soil is of little use. While the solonetz type is slightly acid, the solonchaky-solonetz soil is slightly basic with a subsoil that is intensely basic due to its accumulation of soluble alkali salts. The permeability of the solonchaky type of solonetz is very low, so that the inland waters left by the spring rains dry out only in the early summer. Solonchaks are limey-salty, structureless alkali soils occurring mostly between the Danube and the Tisza. Their soil profile is unstratified; the horizons lack a sharp distinction, and the columnar structure observed in the two foregoing types is absent. The concentration of salts is high even in the uppermostalevel; calcium carbonate is abundant throughout the profile and also occasionally in the subsoil. Solonchak soils make croplands of poor quality, and they can only be improved by treatment with gypsum.

On the basis of their characteristics the solonetz soils can be changed by irrigation into fertile alkali soils on which satisfactory harvests can be produced with suitable agricultural technics. The only method for utilizing the solonchaky-solonetz types is rice production. The solonchaks can be improved only with large investments. The most economical method seems to be using them for satisfactory pasture and meadow agriculture with plantation of honey grass and grub grass.

\section{MEADOW SOILS}

Meadow soils have generally developed along extensive flood areas, in silted-up river-beds, larger hollows and flats, through the influence of stagnant pools of water or marsh vegetation that requires a high ground water level and much moisture. Meadow soil contains much organic material and has a thick layer of humus. The upper part of the soil profile is greyish black, becoming pitchblack farther down. Its structure is generally compact and the clayey soils exhibit polyhedral fracture. These are the socalled meadow clays. A frequent sub-type of the meadow soils is the meadow soil with alkali subsoil. This has, at the lower limit of the humus layer, a 
considerable concentration of sodium, and the structure of this sodic layer is very compact and columnar. Another intermediate form of meadow soils shows affinity with the steppe soils. This meadow soil of steppe character was at the beginning of its development a meadow soil. However, as soon as it was liberated from the influence of water, either by a natural process or by artifical drainage or canalization, the steppe character immediately began to be impressed upon the soil profile. The upper layer of these soils is of a steppe character, of a favourable crumbly structure and browner in colour. Only the lower layers reveal the traces of the meadow soil formation. The geographical distribution of meadow soils is very varied. Apart from the former higher flood plain levels of the rivers, they also frequently occur in the waterlogged flats between the Danube and the Tisza and among the sand dunes of the Nyirség (Figure 1.17-21). As a result of their varied extension, chernozem-type meadow soils may also occur beside swampy meadow soils.

\section{BOG SOILS}

Bog soil types are found in all parts of the country in low, humid flats and small depressions (Figure 1.22-23). They are most frequently found along the shores of standing waters as well as in the filled-up river branches and oxbows in the flood plains of larger rivers. The high organic matter content of the bog soils is supplied by the sedge and swampy plant associations growing luxuriantly on the shores. Two types of bog soils may be distinguished depending on the degree of humification of the organic matter they contain: mucks and peaty bog soils. In the former the organic constituents are completely humified. The colour of this soil type is black; its structure generally is very loose, light and friable. The largest areas of muck soils are located east of the Tisza, between the Berettyo and the Körös Rivers (in the Great and Little Sárret), in the Rétköz north of the Nyirség, in the Hansagg area of the Little Plain, as well as in the swampy area south of Lake Balaton (Little Balaton and Nagyberek), and in the Sárrét of Fejér County. Smaller areas occur in the depressions of the sand plateau between the Danube and Tisza and along the Danube-valley canal. The geographical extension of the peaty bog soils is much the same as that of the mucks. In the peaty soils, the organic substances are humified only in the thin upper layers, whereas, in the lower strata which are isolated from atmospheric oxygen and frequently are 1 to 2 metres thick, the structure of the decaying plants can still be recognized easily. The colour of this type of soil is black or dark blackish-brown, and its reaction slightly acid or 
neutral. In some regions where thicker layers of peat occur, this deposit of high caloric value is exploited for fuel; elsewhere, it is used as a fertilizer. Besides the soil types described above, several other kinds of soils occur in Hungary, but since they cover only very small areas they will not be discussed in detail. This survey of the principal soil types of Hungary and the enclosed map will help to illustrate the great variety of soils characteristic of this country (Figure 1).

\section{BIBLIOGRAPHY}

Mándy, T. and Olvôs, E. (1960). A nyirok kérdès ès a felszini mállàs (The "nyirok" question and the surface weothering). - Foldtani Közlöny, Vol. 90. pp 192-198.

Máté, F. (1960). Javaslat a hazai rêti talajok osztályozásához (Proposal to the classification of Hungarian meadow soils). - Agrokemia ès Talajtan, 1, Vol. 9. pp 121-134.

Sigmond, E. (1934). Általános talajtan (General soil science). - Budapest: saját kiadás, p 696.

Stefanovits, P. (1959). A magyarországi erdôtalajok genetikus talajföldrajzi osztályozása (Genetic soil geographical classification of the Hungarian forest soils). - Agrokémia es Talajtan, 2, Vol. 8, pp 163-184.

Stefanovits, P. (1963). Magyarország talajai (Soils of Mungary). 2. kiad. - Budapest: Akadémiai Kiadó, p 442.

Stefanovits, P. (1971). Brown forest soils of Hungary. - Budapest: Akadémiai Kiadó, in print, p 288.

Stéfanovits, P. and Máté, F. (1960). Javaslat a hazai láptolajok osztályozásảhoz (Proposal to the classification of the Hungarian boggy soils). - Agrokémia es Talajtan, 2, Vol. 9, pp 277-283.

Stefanovits, P. and Szücs, L. (1961). Magyarország genetikus talajtérképe (Genetic soil map of Hungary). - Budapest: OMMI, p 75. (OMMI kiadványai, Ser. 1. Genetikus talajtérképek 1.)

Szabolcs, J. and Jassó. F. (1959). Magyar szikes talajok osztályozása (Classification of the Hungarian alkali soils). - Agrokémia és Talajtan, 3, Vol. 8, pp 281-300.

Szabolcs, J. and Jassó, F. (1961). A szikes talajok genetikus típusai és elterjedésūk tōrvènyszerûségei a Duna-Tisza kōzen (Genetic types and regularities in the occurrence of alkali soils in the lowland between the rivers Danube and Tisza). - Agrokémia és Talajtan, 2, Vol. 10, pp 173-193.

Szücs, L. (1959). A hazai csernozjom talajok osztályozása (Classification of chernozem soils). - Agrokémia és Talajtan, 1, Vol. 8, pp 83-92. 


\section{PART TWO \\ ECONOMIC GEOGRAPHY}




\section{GY. ENYEDI}

The purpose of this brief study is to summarize the regional development of Hungary's national economy since the initiation of the planned economy. The changes in the regional structure of the economy indicate that regional development, while depending on the local development concepts, is primarily determined by the economic policy of the country as a whole. In recent years Hungarian economic policy has emphasized the development of the backward regions and a rational regional distribution of the productive forces.

When the planned economic policy was launched shortly after World War II, the economic levels of the various regions of the country were considerably disparate despite the small size of the country. The diminution of these differences was among the very first targets of the planned economy. In the actual programm of development many new regions were concentrated on, and while earlier disproportions were eliminated, new ones took their places. Hungary's postwar regional economy in general can be characterized by an intense spatial concentration of the productive forces and by an acceleration of the population's geographical mobility. Experience has proved that the regional levelling of a country cannot be realized on the whole because some regions always will show a backwardness relative to others of extraordinary dynamism. At best regional program can only check the deviations from the average and assure that the backwardness of a given area will not be permanent.

The chief targets of the planned economy and their effects on regional development can be summed up as follows:

1. Reconstruction after the war (until 1949). Three to four years were required to rebuild industry and the communication systems, and it took 10 years to redevelop agriculture. During this period it was principally the prewar regional structure that was reconstructed. The fundamental contradiction of the period was the disproportionate economic role of Budapest. Nearly 50 percent of all industrial workers were employed in the capital and there was a great difference between the infrastructure and living standards of Budapest and the other parts of the country.

2. Rapid and extensive industrialization (1949-1957). The rapid development of heavy industry and energetics intensified the activity of the existing industrial centres (mainly Budapest), and resulted in the vigorous development of the mining districts, for example those in the Hungarian Mountains. The development of coal and bauxite mining and steel metal- 
lurgy caused development of new towns and industrial regions. Extensive industrialization absorbed a large number of labourers from the agricultural areas.

3. Restructuring of industry and intensive development (1957-1962). The chief target of this period was the modernization and advancement of those branches of industry that require a small quantity of raw material and a great number of specialistits and skilled workers; for example, the chemical industry, instrument manufacture, electronics etc. As the existing plants were modernized the traditional manufacturing centres, especially Budapest, became predominant.

During this period collectivization of agriculture led to the large-scale migration of the agricultural population, however, the abundant labour supply impeded intensive industrial development.

4. Rise in the technical level of industry and vigorous development of agriculture (1962-1968). - This period can be characterized by a decreased inflow of the agricultural population into industry. Agricultural labourers became more or less stabilized as they attained the average income of the non-agricultural population. In industry accumulation of capital was accelerated. In the principal industrial centres the branches of industry associated with agriculture or those employing unskilled labour (e. g. the textile industry) declined in importance and were relocated in the agricultural regions.

5. The new system of economic motivators. The new economic policy (launched on the first of January 1968) increased production efficiency and emphasized marketability in international trade. The chief methods of the economic reform are: decentralization of economic management; accentuated market orientation; direct financial interest for labourers and managers in enterprise profitability; elimination of central planning instructions; and realizitions of targets through a fiscal price-credit policy. The new system also is attempting to stimulate plant location in the backward regions by economic means such as free supply of public utilities, tax benefits, loan of plant sites etc. Preferential state subsidy was concentrated first of all on the 6 largest provincial towns and secondly on 20 to 25 smaller ones in order to establish vigorous provincial centres. These towns are expected to develop further thorough the accumulation of capital.

As stated previously the changing economic policy accentuated the develupment of new regions. Although the general target was the development of the backward regions, the further industrialization of Budapest proved to be more advantageous at least for the short run. While industrial development is only one aspect of economic development, the degree of industrialization is a measure by which the economic level of each region can be determined. 


\section{The regional structure of the economy}

In Hungary there are three types of regional structures which can be distinguished by the role each plays in gross national production:

1. Agglomeration of Budapest

2. Highly developed provincial regions

3. Underdeveloped provincial regions

These regions (Figure 1) show striking differences in economic level, in the proportion of industry and agriculture, in infrastructure, as well as in employment, personal incomes and consumption. Although the "economically developed" and "industrially developed" regions coincide, the disad-

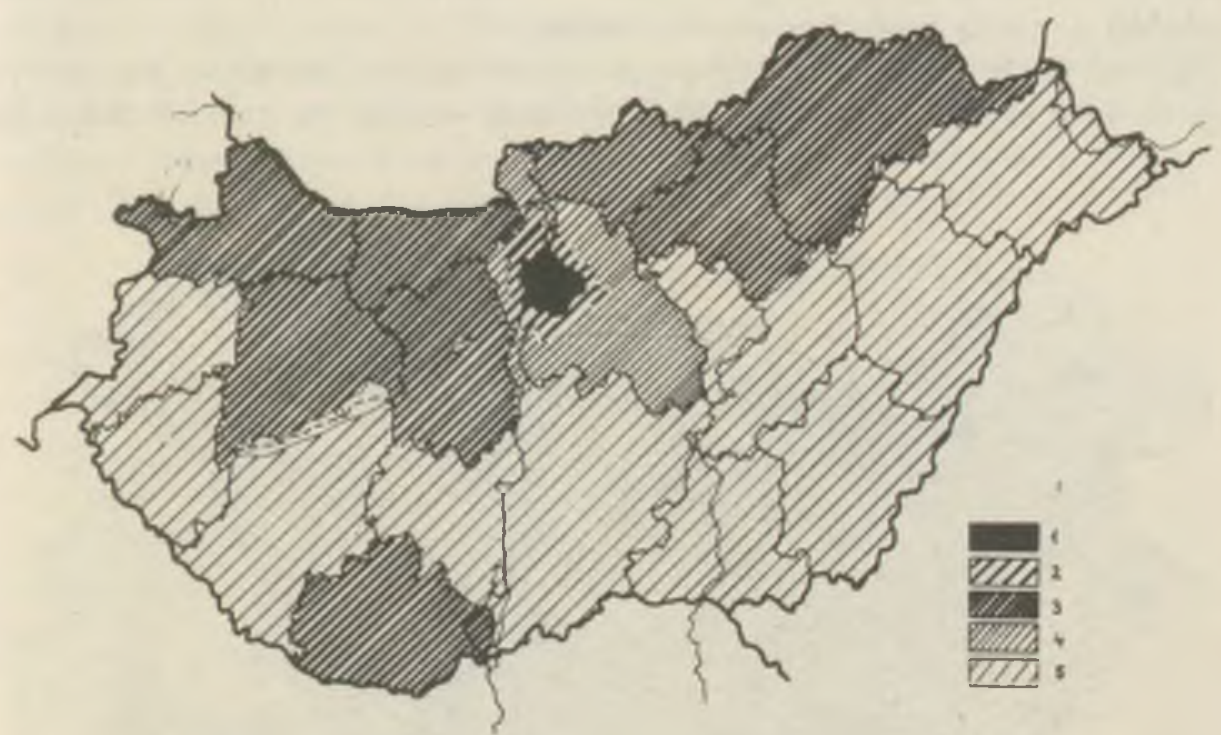

Fig. 1. Regions of differing economic development. $-1=$ Budapest; 2 =agglomeration of Budapest; 3 = developed provincial regions: $4=$ Pest County fouter ring of the agglomeration of Budapest); $5=$ underdeveloped provincial regions

vantages of underdevelopment in some counties are compensated for by a high agricultural level. Therefore the differences between the gross national incomes of counties (2.8 fold) and per capita personal incomes $( \pm 30$ percent of the national average) are by far below industrialization (per capita national income produced by industry) which frequently show a tenfold deviation among the counties. 
The geographical location of industry is still intensely concentrated. Forty percent of the total industrial labourers are employed in Budapest, and 45 to 50 percent of them work in the agglomeration of Budapest.* An additional 20 percent of the industrial manpower is concentrated in 10 provincial towns (Figure 2).

The industrialization of the provinces resulting from the decentralization policy developed several other industrial regions outside of Budapest. The most considerable development occurred in the Northern Mountains (Miskolc and her environs), in the Bakony Mountains (Veszprém-VárpalotaAjka-Székesfehérvár), and in Southern Transdanubia (Pécs-Komló). - In the 1950s the mining districts were developed, and then they became multiple-branched industrial regions; metallurgy, production of energy, and chemical industries were located there. This period of industrialization was oriented primarily toward production of coal.

In the 1960s medium and large provincial towns (including the former agricultural market towns) were industrialized in order to intensify the eco-

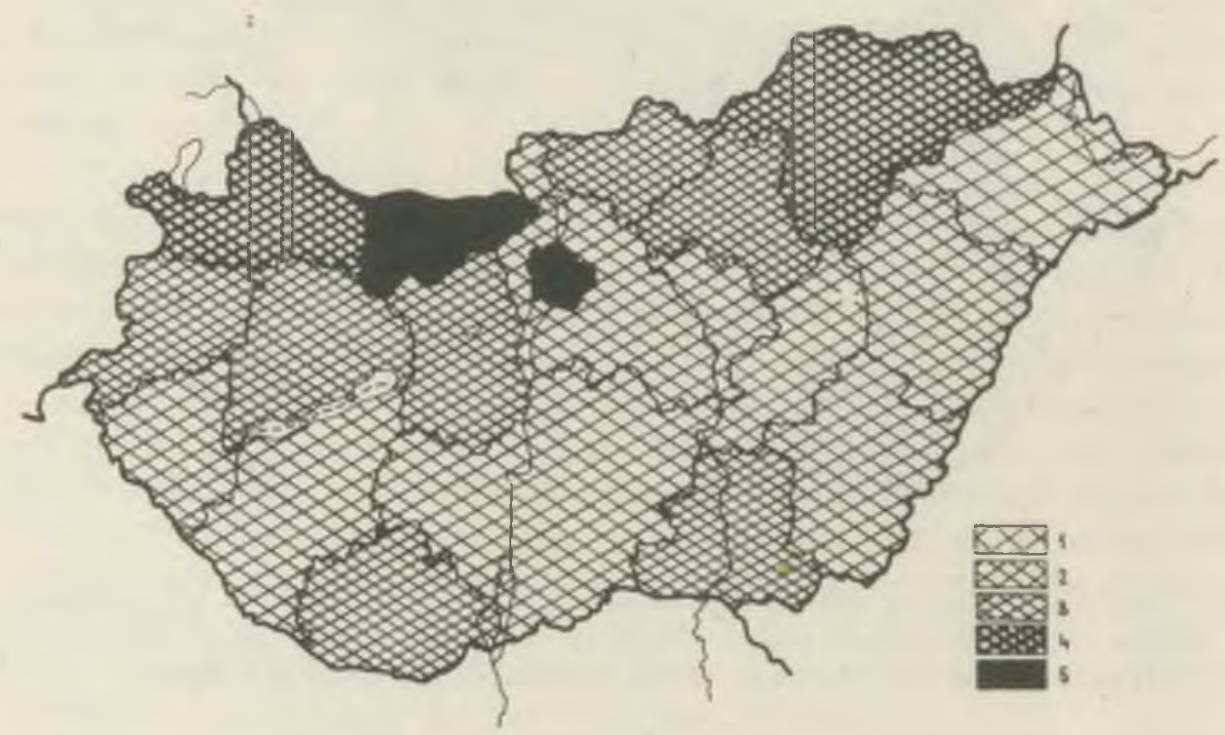

Fig. 2. Industrialization level in 1965. - Number of workers employed in manufacturing industry per 10,000 inhabitants: $1=\langle 500 ; 2=501-1000 ; 3=1001-1500 ; 4=1501-$ $2000 ; 5=>2001$

- It should be noted that while the proportion of industrial labourers decreased considerably, the absolute number of them increased during the past 20 years. In 1948 about 400000 labourers or as much as 55 percent of the total worked in Budapest. At present, 40 percent of the work force totals, 650000 labourers! 
nomic and population-absorbing activities of the regional centres. As a consequence, the highly developed regions extended considerable in size, and several new industrial centres grew up in the Great Plain region (Szolnok, Debrecen, Szeged) as well. Since that a greater emphasis has been placed on manpower recruitment and deliberate decentralization in the location of industry.

\section{THE GEOGRAPHICAL LOCALIZATION OF AGRICULTURE}

Hungary's agriculture is characterized by a relatively low degree of farming specialization because the small peasant holdings have preserved the old traditions of subsistence farming. This fact is evident from the quite even geographical distribution of bread crops. Besides capital deficiency, the relatively high density of the agricultural population sets a barrier against specialization, ${ }^{*}$ i. e. a multiple-branched economy would provide more employment opportunities for the population.

Physical (mainly climatic) conditions are relatively homogeneous throughout the small territory of the country. At the same time even today soil conditions have a considerable effect on the regional development of agriculture (Figure 3 ). The cooperative and state farms producing on fertile

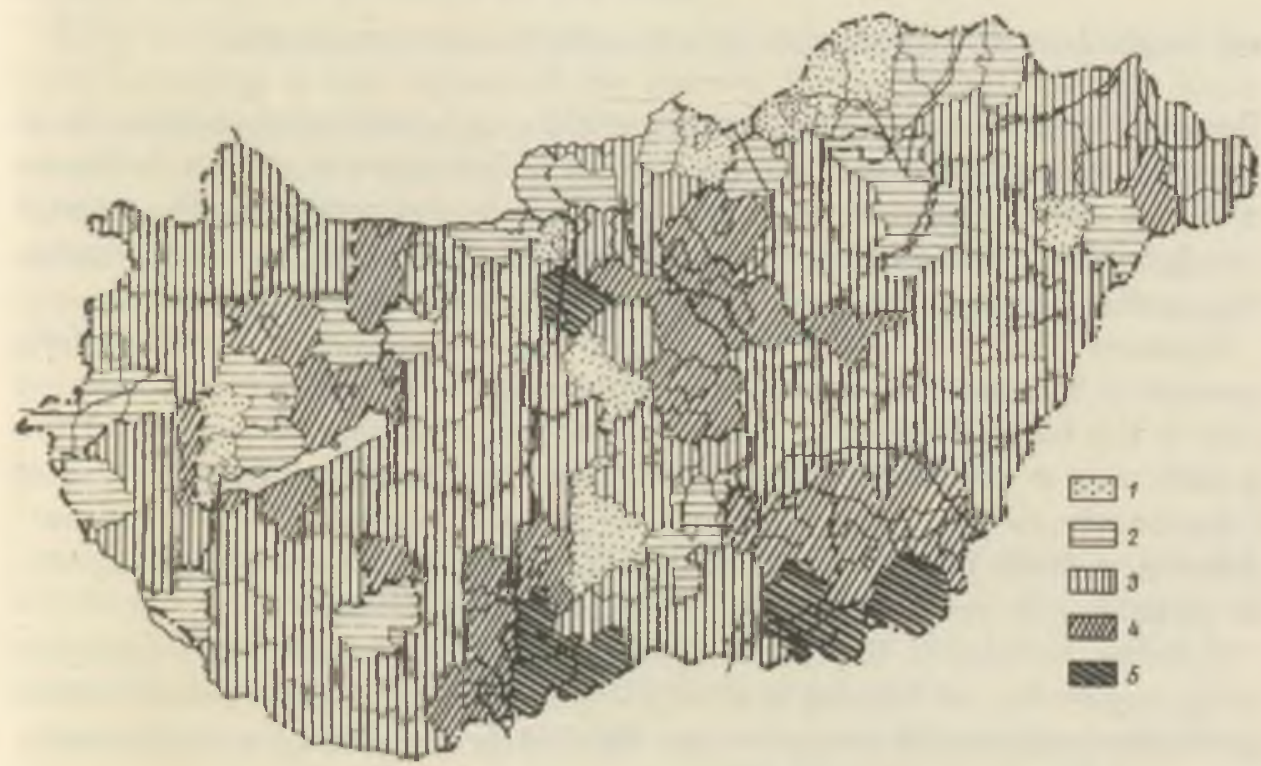

Hig. 3. Ierritorial difference in the level of agriculture according to counties (on the basis of the national income produced by agriculture per 1000 ha agricultural land). $1=$ very low; $2=$ low; $3=$ average; $4=$ advanced; $5=$ well developed The maps were campiled by L. Lackó

- In 1968 agricultural population made up 29 percent of the total. 
chernozem soils are capable of more development, and already show an increasing accumulation of capital. As a consequence the Great Plain has attained the same level as Transdanubian agriculture whereas before World War II, this region was less productive. At the same time, in the mountainous and hilly regions agriculture encounters chronic difficulties, is becoming more and more backward and is in need of state support.

During the post-war period the economic signifiance of the production of maize, meat, some industrial crops, vegetables and fruits increased. All these crops find especially favourable conditions for production in the Great Plain. During the prewar years the mountainous and hilly regions were predominated by dairy farming. However, its unprofitability resulted in the stagnation of agricultural production in the areas mentioned before.

In the past 10 years the establishment of large-scale vineyards and orchards has created a significant regional concentration - a new phenomenon in the spatial structure of agriculture - and has changed extensive agricultural areas into horticultural regions.

It should be mentioned that most of the highly developed agricultural regions are poorly industrialized, although the two activities are not mutually exclusive.

\section{THE GEOGRAPHICAL DISTRIBUTION OF POPULATON AND SETTLEMENTS}

The most striking feature of the population and settlement pattern is a regional disproportion manifesting itself in a high growth rate in Budapest and in a deficiency of large industrial towns in the provinces. The capital has 2 million inhabitants or approximately 20 percent of the total population and some of its tertiary branches exceed industry in importance.

Between 1949 and 1966 the total work force increased by 1 million. Fifty percent of this increase was in the agglomeration of Budapest, 40 percent was in the highly developed provincial regions and only 10 percent of the growth was in the backward regions. Such an uneven geographical distribution of new employment led to a large-scale migration from the underdeveloped areas (chiefly the Great Plain) to the highly developed regions. In recent years, however, this trend has been slowed down.

Another feature of the population and settlement pattern in Hungary is the separation of working and dwelling places which results in a serious commuter problem. At present some 900000 people in Hungary commute. Budapest alone receives 250000 commuters each day.

The remote northern counties (Hajdú-Bihar, Szabolcs-Szatmár) are providing more and more of the labour reserves of the country, and presently 10 percent of the commuters go home only once a week, or once a fortnight. 
As a matter of fact, regions with a population decrease show abnormal adverse demographic patterns as well. The disproportions of the settlement pattern are motivated by: the extremely high growth rate of Budapest; the relative weakness of the secondary centres; and the one-sided and out-of-date functions of the small and medium-sized towns.

Currently, 50 percent of the total population lives in towns.* The large provincial towns are peripherally situated near the frontiers, and their populations do not make up 200000 in number. Smalt- and medium-sized towns show an anomalous and sparse pattern in the Great Plain. Of course, they bear marks of history, and also of the new frontier lines drawn after World War II. In the last 20 years the urban network of Transdanubia and the Northern Mountains underwent an appreciable development, however, the new towns that were founded by socialist industrialization could not make any improvement on the disproportions of the settlement pattern because nearly all of them were established in the vicinity of old towns. Only Dunaújuáros was able to develop as a viable urban center. A slight change took place in the Great Plain which for the most part remained an agricultural region. In this area the chief task is to encourage the further development of the existing agricultural market towns. The urban netwolk cannot be extended at this time.

Rural settlements can be differentiated by size, structure and development according to the regions of the country. In the Great Plain the large rural settlements favour large-scale agriculture and infrastructural development. Here the chief problem is caused by the dispersed farmsteads (the "tanya" population). In the mountainous and hilly regions there are a considerable number of small villages (with less than 1000 inhabitants), however, these villages nave undergone a rapid depopulation in certain areas.

\section{DEVELOPMENT PROBLEMS OF THE AGGLOMERATION OF BUDAPEST}

The agglomeration of Budapest (Budapest and 45 settlements in her environs) is a multiple-branched manufacturing centre - the largest in Eastern Europe. In the past 20 years, 40 percent of the total capital investments were concentrated in this relatively small area.

The relationship between Budapest and her outer zone of communities is changing. In the first years of the planned economy the settlements in

- An international comporison of the urban population is obstructed by the divergent statistical concepts of a "Town". In Hungary urban population is presumed to be living in an administrative town. We have several settlements with 15 to 20000 inhabitants which carry out urban function but are not regarded os towns. At the some time, we have some towns where as yet 30 to $\mathbf{4 0}$ percent of the population is employed in agriculture. 
the outer ring still had a significant town-supplying agriculture, the manpower released from agriculture migrated chiefly to Budapest, and commuting was not as common as at the present time. In the 1950s and early 1960 s commuting became general, agriculture declined or became a female occupation, and the communities around Budapest became dormitory settlements. As a result of the last 6 to 8 years' decentrazilation policy some industrial activities were relocated in the outer ring and a relatively rapid development has resulted. In the opinion of this author the "small decentralization" of 20 to 30 kilometres will enlarge the agglomeration area, as it extends manpower attraction over a far larger area.

The further development of the Budapest agglomeration is a much debated issue on which opinions are divided. Arguments against the further development of the agglomeration include the following considerations:

1. It deprives the backward areas of the financial means for development.

2. It would be accompanied by a population increase, and the resettlement of new inhabitants is rather expensive because per unit costs of infrastructural development are high in towns with a population of one million. The capital is already overcrowded, and most of the apartments are obsolete. The total cast of relocating one new labourer (per capita intrastructural development) is 400000 Forints - much higher than the cost in the large- and medium-sized provincial towns.

The following arguments have been advanced in favour of the further development of the agglomeration:

1. From the view-point of communication, Budapest has an advantageous situation because all of the main railway lines and routes converge on the capital radially.

2. The presence of research capacity and skilled labour favours the development of the up-to-date branches of industry.

3. The industrial equipment of Budapest is not utilized suitably. Owing to labour shortage, the average number of shifts lag far behind those of the provincial plants. At the same time, industry's labour productivity is by far the highest in Budapest.

It appears that the industrialization of Budapest cannot be stopped. Already, several simple working progresses (food, processing and textile industries) have been relocated and additional relocations have been proposed as well. However, relocation might be directed towards the remote underdeveloped areas of the country instead of the outer ring of the Budapest agglomeration. Those plants which supply the capital and 
require much space and a large number of labourers or those which cooperate with the capital's industry possibly can be relocated in some larger settlements of the outer zone. The great advantages of industrial cooperation and the development of the research capacity of Budapest are important assets. It would not be reasonab!e to separate industries from the universities, libraries and academic research institutes of Budapest because they will continue to enhance the potentialities of the Budapest agglomeration. This process cannot be reversed; it can only be controlled by a decentralization policy.

\section{INDUSTRIALIZATION PROBLEMS OF THE PROVINCIAL. REGIONS}

In 1966 one-third of the manufacturing industrial labourers worked in the highly developed provincial regions. These regions exhibit a more or less one-sided industrial structure of mining and a heavy industrial character.

There are four major provincial concentrations of industry in Hungary:

1. The Little Plain (district of Györ) developed during the AustroHungarian Monarchy, chiefly in connection with the Vienna and Pressburg (Bratislava) markets. This multiple-branched manufacturing region needs a thorough structural transformation; because the traditional textile industry occupies a leading position in its production. In Gyor, the centre of the region, the transportation industry is developing rapidly. This is the only industrial region in Hungary which also has a well-developed, relatively specialized agriculture; it is the most balanced region of the country. The new industrial and service employments have absorbed the manpower released from agriculture.

2. The central Transdanubian industrial region originally had a onesided economic structure dependent on mining but today her dynamic development is supported by a multiple-branched industry. The coal-mining of this area is profitable and the manpower released by the closing of smaller mining works in other areas can find employment in this region. The bauxite and manganese mining is developing fairly well. A number of towns in this region have become centres of aluminium metallurgy and processing, and chemical production. The medium-sized towns of this area have exhibited a sound development. Székesfehervár, where the biggest radio and television factory of the country was recently located, is especially progressive.

3. The south Transdanubian industrial region (Pècs-Komlo) also is well balanced and has hopeful prospects for the future. The high quality coal and uranium deposits of the country have assured the significance of mining in this region. Pécs is a multiple-branched manufacturing centre. 
The border of the region which stretches along the Danube and the Dráva, has a rather backward agriculture; however, the industrialization of this area has started already by utilizing her abundant water sources (for cellulose production).

4. The north Hungarian industrial region is second in importance after Budapest and needs a thoroughgoing reconstruction. The emphasis on mining of coal was decisive in the development of this region and this situation has not changed significantly. Manufacturing is limited almost exclusively to heavy machine and heavy chemical industries. The closing of the uneconomical lignite mines has caused employment problems. This problem is due to the fact that since coal miners receive the highest wages in Hungary it is difficult to find satisfactory new employment for miners who are out of work. For example, if an ex-miner were employed as semiskilled worker, his wages would be reduced considerably so that employment must be provided for his wife who did not work previously. It is true that the backward agricultural regions were deprived of considerable financial means by the reconstruction of the out-of-date industrial regions. However, besides the social aspects of full employment, the existing infrastructure of the mining districts justify transformation of the area into a manufacturing region.

In the northern industrial region agriculture production is significant. However, it is difficult to mechanize agriculture in the sloping, eroded arable lands, of the area, in addition, production costs are higher and yields are lower than those of the Great Plain. The chronic agricultural stagnation of the mountainous and hilly regions can be resolved by a structural change in agricultural production (i. e. by the extension of artificial meadows and pastures) and by the development of cattle breeding. This stratagem would release additional manpower from agriculture thereby making further industrialization of the provincial regions possible.

\section{Problems in the Development of the Backward Regions}

The backward regions can be characterized by a preponderance of agriculture and an abundance of labour resources. Most of the Great Plain and some parts of Southern Transdanubia are included in this category. These areas were left out in the era of the coal-oriented industrialization, and consequently they are lacking infrastructure, skilled labour and research bases. Therefore, these areas are not attractive for the location of new industries. It must be noted that the relative concept of "backwardness" means a negative deviation from the prevailing national standard. Since the end of World War II the backward regions in general have 
undergone a remarkable change showing a quick pace in industrial and infrastructural development and a decrease in backwardness. An abundance of labour, the existence of export and import transportation lines, the recently explored hydrocarbon deposits, and the still unexploited water resources will facilitate the industrialization of these areas.

The principal areas which remain underdeveloped are:

1. The loess ridge of the Great Plain. The counties in this area (Szolnok, Hajdu-Bihar, Békés and parts of Csongrád) seem to be in the most promising situation. The wheat maize and hog specialization on fertile soils has reached an appropriate technical level and is profitable as well. Irrigated areas are growing considerably in extent. In the environs of Debrecen and Szeged a significant oil and natural gas production has been started. A number of urban areas including Debrecen, Szeged and Szolnok already are able to attract industry.

2. The sandy regions of the Great Plain. These counties (Bács-Kiskun and Szabolcs-Szatmár) are more difficult to develop. The living conditions and incomes of their populations lag far behind the average. The best forms of land utilization for this area are plantation cultures of grapes, fruits, and vegetables. These crops, however, create large more or less seasonal demands for manpower and therefore per capita incomes are low. The location of labour-intensive branches and, in the frontier areas the manufacturing of raw materials imported from the Soviet Union provide some possibilities for industrialization of this region.

In South-Southwestern Transdanubia natural endowments favour cattle breeding as a means for future development. The settlement pattern is characterized by small villages which hinder infrastructural development. industrialization can be supported both by the abundance of industrial water power, availability of manpower, and by the proximity of important industrial regions as well.

\section{Prospective Regional Development of the National Economy of Hungary}

When discussing the prospective development of Hungary, two questions must be considered: (a) To what extent will the present pattern of regionalization prove to be lasting and (b) will the development plans be able to change the actual conditions of underdeveloped areas considerably?

As far as can be foreseen, the present pattern of regionalization will not change in the next 15 years. The major task of regional development policy is only to equalize the regions in terms of economic level, income and living conditions. More changes are hindered by two difficulties. First there must be a more intense development of the up-to-date branches of industry 
and technical modernization of existing industry. In other words, the existing plants will be modernized, and only a few new plants will be constructed. The development of the up-to-date branches of industry (synthetic materials, electronics etc.) will be joined with the already existing industrial concentrations and research bases. Secondly, the chronic stagnation of population growth will result in the reduction of new manpower reserves. The number of industrial labourers will increase only slightly. The highest labour increase is expected in the tertiary branches which will deprive the backward regions of the new employments.

Accordingly, the prospect for the productive capacity of the Budapest agglomeration is a continual increase in the dynamic branches of industry. However, as these branches will require only a negligible increase in industrial labour, the agglomeration will suffer a percentage decrease in industrial employment. The modernization of the provincial industrial regions also will require a relocation of industry. The revitalization of coalmining districts too will be motivated by the efficient utilization of the already well developed infrastructure.

For development of the backward areas some simple working processes of plants might be relocated from the industrial regions to these areas. Local authorities should try to attract industrial plants by offering incentives (e.g. tax benefits, provision of sewage services etc.). The national budget provides a "relocation loan" for enterprises which establish new plants in certain underdeveloped areas. It would be reasonable to realize decentralization by concentrating relocation to the larger agricultural market towns.

It is obvious that the economic equalization of regions cannot be realized exclusively by industrializaton. On the contrary, development will be checked by a concentrated character of industrialization. In addition the future development of certain areas must be based on agriculture. The development can be realized in areas with favourable physical conditions through the intensification of up-to-date agricultural methods, particulary vertical integration. The personal incomes of the agricultural labourers have all but attained the level of non-agricultural incomes, and it can be foreseen that the highly developed agricultural regions will not suffer from the disadvantages on income differences any longer. In some areas for example in the region of Lake Balaton the development of tourism can be the motivating force of economic development.

There still are great differences between the living conditions of urban and rural regions. Therefore, the preferential development of infrastructure and the rapid increase in tertiary employment can abate these regional differences. 
Asztalos, 1. (1968). Az állottenyésztés területi megoszlása Magyarországon (Regional distribution of stock-breeding in Hungary). - Budapest: Akadémioi Kiadó, p 250.

Barłke, 1. (1967). Területi egységek iparfejlettségi fokának meghatározása (Determination of the rate of industrialization of regional units). - Kozgazdasági Szemle 7-8, Vol. 14. pp 885-897.

Beluszky, P. (1968). Hièrarchie des villes en Hongrie. - Acta Geographica Debrecina (Debrecen), Vol. 14, pp 327-334.

Bencze, 1. (1964). The distribution of the manufacturing and mining industry of Hungary. - Applied geography in Hungary. - Budapest: Akodémiai Kiadó, pp 179-195. (Studies in geography 2.)

Berná, T. and Enyedi, Gy. (1961). A magyar mezōgazdasági termelès kōrzetei (Production regions of the Hungarian agriculture). - Budapest: Mezógazdasági Kiadó, p 168.

Bernát, T. and Enyedi, Gy. (1968). A mogyar mezōgazdaság területi fejlōdése (Regional development of the Hungarian agriculture). - Foldr. Ert. 4, Vol. 17, pp 4-18.

Bora, Gy. and Koródi, J. (1959). A népesség, a munkaerō ès az ipar területi koncentrá. ciója es a fóvárosi ..túlzsúfoltság" (Regional concentration of the population, manpower and industry and the "overcrowding" of the copital). - Kozgazdasagi Szemle 8-9, Vol. 6. pp 892-905.

Boros, F. (1970). A magyar gazdaság térbeli változásainak tendeciái (Trends of the spatial changes of Hungarian economy). - Földr. Ert. 1, Vol. 19, pp 23-48.

Enyedi, Gy. (1964). Analyse breve du probleme de l'utilisation du sol en Hongrie. Acta Geographica Debrecino (Debrecen), Série 3, Tom. 9, pp 87-108.

Enyedi, Gy. (1964). Geographical types of agriculture in Hungary. - Applied geography in Hungary. - Budapest: Akadémiai Kiado, pp 53-105. (Studies in geography 2.)

Enyedi. Gy. (1964) Le village hongrois et la grande exploitation agricole. - Annales de Géographie 400, Ann. 73, pp 687-700.

Enyedi, Gy. (1965). A mezōgazdaság földrajzi tipusai Magyarországon (Geographical types of agriculture in Hungary). - Budapest: Akadémiai Kiadó. p 71 (Földrajzi tanulmányok 4.)

Enyedi, Gy. (1967). A brief characterization of the agricultural land utilization in Hungary. - Land utilization in Eastern Europe. Budapest: Akadèmiai Kiadó, pp 74-88. (Studies in geography in Hungary 4.)

Enyedi, Gy. (1967). La collectivisation de l'agriculture hongroise, son contenu humain et économique. - Mèlanges de géographie physique, humaine, économique, géographie appliquee, regionalisation et théorie. Gembloux: j. Duculot, S. A. pp 14-24.

Enyedi, Gy. (1969). Nepgazdaságunk területi fejlódésenek problèmái (Problems of the regional development of the Hungarian national economy). - Valoság 12, Vol. 12. pp 1-14.

Enyedi, Gy. (1969). Le probleme du dévéloppement régional dans l'économie hongroise. - Bulletin de la Socièté Languedocienne de Géographie 1, pp 45-65.

Enyedi, I. (1969). A felszíni (talaj)adottságok és a jôvedelem vizsgálata 300 termelöszövetkezetben (Investigation of the superficial (soil) endowments and incomes in 300 cooperative farms). - Földr. Ért. 3, Vol. 18, pp 335-344.

Géczy, G. (1968). Magyararszág mezōgazdasági területe (The agricultural area of Hungary). Budapest: Akadémiai Kiadó, p 307.

Kóródi, J. and Mäıton, G. (1968). A magyar ipar területi kèrdései (Regional problems of the Hungarian industry). - Budapest: Kossuth Kiadó, p 173. 
Kulcsár, V. (1968). Az ország külónbōzỗ területeinek mezōgazdasági fejlettségi szintjei (Agricultural development levels of the different regions of Hungary). - OT Tervgazdasági Intẻzet Közleményei 5, p 37.

Lettrich, E. (1969). The Hungarian tanya system: history and present-day problems. Research problems in Hungarian applied geography. Budapest: Akadémiai Kiadó, pp 151-168. (Studies in geography in Hungary 5).

Lettrich, E. (1964). Urbanization of Hungary in the light of the occupational structure of her population. - Applied geography in Hungary. Budapest: Akademiai Kiadó, pp 164-178. (Studies in geography 2).

Magyarország gazdasági földrajza (Economic gegography of Hungary). Szerk. Radó Sándor. - Budapest: Gondolat Kiadó, (1963), p 368.

Markos, Gy. (1962). Magyarország gazdasági földrajza (Economic geography of Hungary). - Budapest: Kozgazdasági Kiadó, p 581.

Pápai, B. (1965). Budapest népesedési és munkaerohelyzete (Demographical and manpower conditions of Budapest). - Demográfia 2, Vol. 8. pp 229-245.

Pécsi, M. and Sarfalvi, B. (1964): The geography of Hungary. - Budapest: Corvina, p XIV. 300.

Petri, E. (1969). The collectivization of agriculture and the tanya sysytem. - Research problems in Hungarian applied geography. Budapest: Akademiai Kiado, pp 169-182. (Studies in geography in Hungary 5).

Sórfalvi, B. (1964). Internal migration and decrease of agricultural population in Hungary. - Applied geography in Hungary. - Budapest: Akadémiai Kiado, pp 150-163. (Studies in geography 2).

Sárlalvi, B. (1965). A mezōgazdasági népessèg csōkkenése Magyarországon (Decrease of agricultural population in Hungary). - Budapest: Akadémiai Kiadó, p 122. 


\section{THE ECONOMIC REGIONS OF HUNGARY}

GY. KRAJKO

In the course of the past two decades, a number of experiments have been made with the economic regionalization of Hungary. The delimitation of the economic regions has a great importance for scientific research as well as for regional planning. The traditional administrative division of the country (formed basically in the Middle Age) is not suitable for a regional framework of a modern economy.

The division of economic regions expresses the existing division of labour among the different geographical areas of the country, and the regional system of the economic connections.

The experiments - having different aims and methods - have had different results. The number of delimited regions has been between 6 and 12 .

The economic regionalization presented here have been based on several criteria.

1. Four hierarchical types of region have been defined. They are: macro-. mezo-, sub- and micro-regions.

2. The following factors have been used to characterize the various regions:

a. the specialization of the regions, significance and number of their functions,

b. the size of the territory of the region.

c. production, trade and transport relations,

d. the model of the economic growth of the given region,

e. demography (incl. the manpower problems).

f. physiographic conditions of the economy.

The region of higher degree incorporates all functions of the lower ones.

\section{Macro-regions}

\section{THE CENTRAL REGION}

The Central region has the smallest area $(6,787 \mathrm{sq} . \mathrm{km}$.) of the macroregions of Hungary, and with its population of $2,787,000$ it is in third place among the macro-regions. It is obvious from the highly centralized regional distribution of the productive forces of Hungary that through its economic and political functions Budapest has created a very strong attraction zone. 
There are many reasons for singling out Budapest and its environs as a uniform macro-region:

1. The exceedingly close internal production, distribution and transport relations make divisions into lower levels unrealistic.

2. The functions fulfilled at the macro-level do not exclude functions at a lower level.

3. The parts of this region - with the exception of Dunaujivaros and its environs - do not fulfil any independent regional functions because together they form the economic, political, and cultural centre of the country.

4. A comparison at the sub-regional level would be impossible and unrealistic.

5. Neither economic, nor methodological viewpoints justify the division into lower levels.

Keeping in mind these factors, Budapest and its environment will only be discussed as a macro-region.

It is difficult to delimit the Central region because its economic and cultural attraction extends over all of the country with almost uniform intensity. Its physical boundaries, however, end where the functions of the regional production complex of Budapest are taken over by the production units of Tatabánya, Fejẻr, Nógrád, Szolnok, and Kecskemét counties. The industrial character, the size, and the importance of the Central region as a regional unit are well-known.

THE GREAT PLAIN

The Great Plain is the largest (37,857 sq. km.) and most populous $(3,150,000)$ but least industrialized macro-region. It owes its unity to a number of direct and indirect factors which led to the development of unique characteristics. These factors include: (a) the similar industrial and agricultural pattern of the region; (b) the similar industrial and agricultural character; (c) the fact that it will become one of the most quickly developing industrial regions; (d) its peculiar economic and historical development which differs from that of the other parts of the country; (e) the uniform agricultural character of the region; (f) the similar development problems of its industry, agriculture, and network of settlements; $(g)$ the similar manpower-balance and manpower-management problems; $(h)$ the fact that a uniform plan, extending over all the Great Plain is necessary to utilize the water of the river Tisza and its tributaries; and (i) the approximate uniformity of the geographical conditions (except the soil). It is therefore not the inseparably close interrelation of the internal con- 
nections of developing regional complex, but the similar character, the direction of development and the natural interdependence of several smaller regions (developing production units) which give unity to the region.

\section{TRANSDANUBIA}

Transdanubia with its population of $2,961,000$ and its area of 35,927 sq. $\mathrm{km}$. is a grouping of mezo-regions differing greatly from each other. A number of factors unify these areas into a macro-region. The include: (a) the reasonable regional utilization of the energy resources; (b) the regional connections of the different industrial branches; (c) the specialization characterizing the greater part of the region; (d) the uniform transport network; (e) the geographical conditions of most of the region which differ from those of the Great Plain; ( $f$ ) the unique economic and historical development of the greater part of Transdanubia which differs from that of the Great Plain; and $(\mathrm{g})$ the problems of the development of the mezo-regions such as the development of coal mining, settlement problems, water supply problems, etc.

\section{NORTHERN HUNGARY}

Northern Hungary with its $12,462 \mathrm{sq}$. km. and 1,266,000 inhabitants is somewhat similar to the Central region because it also includes the functions of the mezo-region. Due to its specialization, regional production connections, development problems and geographical conditions it is the most developed regional production complex after the Central region.

\section{Mezo-regions and Sub-regions}

The identity or unity of macro-regions breaks down if problems of a regional character are studied at the mezo-region level. The Great Plain includes two mezo-regions and Transdanubia has three such regions (Figure 1).

THE SOUTHERN GREAT PLAIN

The internal unity of the southern part of the Great Plain (18,520 sq. km. and $1,471,000$ inhabitants) is due to its industrial character based on the agricultural products and raw materials. It has meat, canning, sugar, grain 
milling, and textile industries, crude oil and natural gas, as well as different kinds of agricultural production (wine, fruit, wheat, maize, industrial crops, vegetables, hog and poultry breeding). It also is unified by the increasing and extensive economic and cultural attraction of Szeged. The common problems in the development of the industry, agriculture and transport, and in the reasonable utilization of manpower are similarly important in its unity.

In the southern part of the Great Plain there are 3 smaller regional units developing which, in spite of their similarity, differ from each other in many respects:

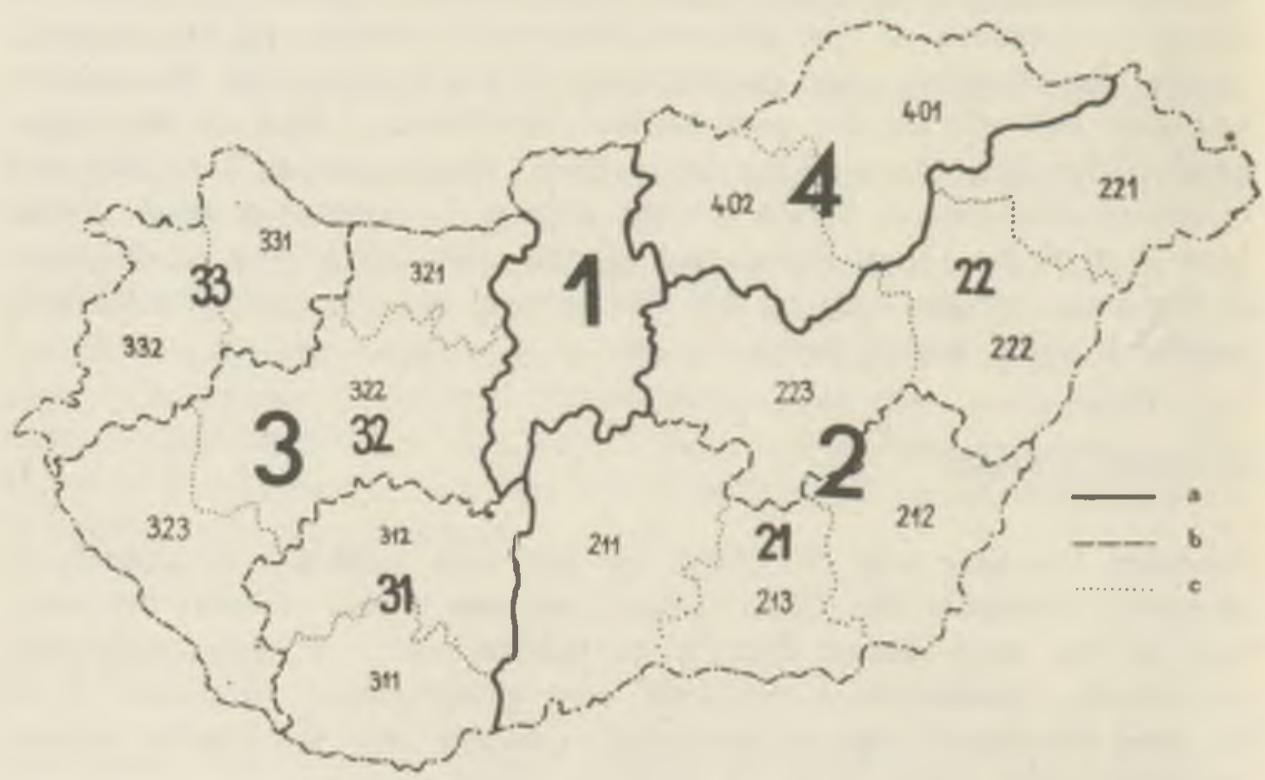

Fig. 1. Economic regions of Hungary. $-1=$ Central Region; $2=$ Great Plain; $21=$ Southern Great Plain; Sub-regions: $211=$ Danube-Tisza; $212=$ Békes: 213 = Szeged: 22 = Northern Great Plain: Sub-regions: 221 = Szabolcs: $222=$ Debrecen: 223 = Szolnok: 3 = Transdanubia; $31=$ Southern Transdanubia; Sub-regions: 311 = Baranya: $312=$ Tolna $; 32$ = Central Transdanubia $;=321=$ Komarom: 322 = Fejér-Veszprém: 323 = Zala: 33 = Little Plain: Sub-regions: $331=$ Györ: $332=$ Western Transdanubia; 4 = Borsod region; Sub-regions: $401=$ Borsod; $402=$ Nograd. - a = boundary of region; $b=$ boundary of mezo-region; $c=$ boundary of sub-region

1. In the sub-region of the Danube-Tisza Interfluve $(8,590 \mathrm{sq} . \mathrm{km}$. and 589,000 inhabitants) the peculiar soil and climatic conditions make it possible to produce wine, fruit and vegetables and therefore a considerable canning industry developed. In addition to the food processing industry the metal industry is quickly developing in Kecskemét, Kiskunfélegyháza. and Baja. 
The special agricultural problems of the sub-region are: increasing the fodder supply; developing animal husbandry; increasing the use of organic tertilizers; organizing the large-scale production of wine; developing the mechanization, storage, and transportaition facilities for the food industry. Special problems also exist in the industries of this region: the canning industry and the agriculture have not been able to attract the manpower necessary for development; and other branches of the light industries and the metal industry need to be developed.

2. In the sub-region of Békés $(5,668 \mathrm{sq}$. $\mathrm{km}$. and 446,000 inhabitants) the soil, the agriculture and the regional production differ considerably from the region between the Tisza and the Danube. Hog breeding and poultry farming based on maize and cereal production have made it possible to establish a well-developed meat industry. The grain milling and sugar industry also have been founded upon the agricultural basis. Manpower has been attracted by the textile industry of the region.

This area also has special economic problems. With the mechanization of agriculture more manpower has been freed than the food processing and textile industries have been able to absorb, and therefore the establishment of other industrial branches has become necessary.

3. The sub-region of Szeged (4,262 sq. $\mathrm{km}$. and 435,000 inhabitants) combines the agricultural characters of the other sub-regions. Accordingly, the meat, grain milling and canning industries have developed in this area. The town of Szeged is the most industrialized sub-region of the Great Plain. In addition to the food processing industry it has considerable light industry (textile, wood and leather), crude oil and natural gas production; as well as an electronic and precision machine industry. In the economic development of this sub-region the production of crude oil and natural gas has become most important. The employment of the manpower is a constant problem. Taking into consideration the physical conditions of the county the future development of the chemical and precision machine industries seems to be realistic.

\section{THE NORTHERN GREAT PLAIN}

This region (19,337 sq. $\mathrm{km}$. and 1,679,000 inhabitants) has an agricultural character; it is the least industrialized part of Hungary. Its boundaries are sharper in the North than in the South and in the West. In the South the boundaries of the region follow the county boundaries because the broad "transitory zone" can best be delimited in this way. In the West are included the districts of "Cegléd" and "Nagykáta" as the irrigation system of Kisköre extends over this area. 
The unity of this region is shown by several factors including: the irrigation system which covers a great part of the region; the similar character of agriculture in a large part of the region; the food processing industry which has developed from the agricultural base; the developing chemical and machine industries: the production of natural gas and crude oil; the high population increase; and, as a result of the weakly developed industrial base, the largest manpower reserves. Due to these factors the development problems of the settlement network and of the industry and agriculture are similar. The unity of the region also is strengthened by the transport network. No uniform regional production complex extending over the whole area of the region has developed as it has in the Southern Great Plain. Only production units including weakly developed small regions can be distinguished.

The mezo-region can be divided into three sub-regions:

1. The sub-region of Szabolcs (5,934 sq. $\mathrm{km}$. and 559,000 inhabitants) is the least industrialized area of the country. At the same time, it has the highest population increase and therefore has the greatest manpower reserves. In its agriculture the production of fruits, potatoes and vegetables as well as the related canning and distilling industries are predominant. In this respect it differs from the other sub-regions of the area. The development of agriculture and industrialization are great problems in the region.

2. The sub-region of Debrecen $(6,211 \mathrm{sq} . \mathrm{km}$. and 516,000 inhabitants) is much more industrialized than the Szabolcs region, however, no one branch of the industry has a great importance in the national economy. There also are essential differences in its agriculture. The production of maize and cereals is more significant in this sub-region, and consequently, animal husbandry and the meat processing industry are more developed. In addition to the industry that has developed on the agricultural base, the machine building and the chemical industries are included in the area's specializaton. Like in some regions of the Great Plain, the efficient employment of manpower is the central problem here.

3. In the sub-region of Szolnok (7,192 sq. $\mathrm{km}$. and 604,000 inhabitants) the structure of the agriculture is identical with that of the region of Békés: still, the combination of the two regions is not advisable because with the building of the irrigation system of Kisköre the agriculture of the sub-region is expected to change. Furthermore, there also are essential differences in the character of the industries of the two regions. On the Great Plain the heavy industry is most concentrated in the sub-region of Szolnok. Accordingly, besides the food processing industry (grain milling and sugar industry) the machine and the chemical industries have developed significantly in Szolnok, Jászberény, and Törökszentmiklós. The centre 
of the crude oil and natural gas production of the Great Plain also is in this region.

The number of commuters in the Szolnok sub-region is very high, especially in the western part, which is in Budapest's sphere of attraction. The future development of industry and the extension of irrigation are expected to provide employment in the region for the manpowar reserves.

\section{SOUTHERN TRANSDANUBIA}

Drawing the boundaries of Southern Transdanubia $(10,271 \mathrm{sq} . \mathrm{km}$. and 822,000 inhabitants) in the North and in the West is problematical. Like in the Great Plain there is a considerable transitory zone which does not make it possible to draw the boundaries of the region sharply. In the North it is advisable to accept the boundaries of the county as boundaries of the region. In the West Somogy County had to be divided because a portion of it is an area of attraction of the Lake Balaton and the second portion has a basically agricultural character.

The region includes two different sub-regions which are closely related economically and culturally. For instance, a large part of the manpower reserves in the Tolna and Somogy Counties are employed in the county of Baranya; the character of agriculture is similar in both, the transportation network is uniform, and finally, the attraction of the town of Pècs extends far to the North. Therefore, it is not so much the production complex extending over the whole region that forms the unit but other factors that unify the two regions.

The sub-regions of Southern Transdanubia are as follows:

1. The sub-region of Baranya (4,530 sq. $\mathrm{km}$. and 41,300 inhabitants) is a newly developing coal mining area which, however, is much weaker than that of Borsod. Half of the workers engaged in the industry are employed by the coal and uranium mining. The production of electric energy, the small machine building and the chemical industries are connected with the coal mining. The light industries and the food processing plants of this region are of national importance. The economic development is based on mining and on the developmental problems connected with it.

2. The sub-region of Tolna is industrially underdeveloped (5,741 sq. $\mathrm{km}$. and 409,000 inhabitants). It has a regional production unit developing around the textile and food processing industries. It has a considerable manpower reserve which cannot be engaged by the development of agriculture, and therefore, it is justifiable to develop the labour-intensive branches of industry, and with the building of the atomic power plant on the Danube it will be possible to develop these branches which require much energy. 
Central Transdanubia (17,253 sq. km. and 1,387,000 inhabitants) is a mezoregion with a primarily industrial character. A developed regional production complex which ensure the unity of the region has evolved in its central and northern parts. The basis of the regional economy is mining (coal, crude oil, bauxite, manganese, etc.) to which the production energy, as well as the aluminium industry, the chemical industry, and machine building are connected. According to future development plans the decrease of coal mining will be counterbalanced by the development of the aluminium industry and machine building. Light industries and food processing have a smaller importance in the region.

The above mentioned production unit rather than the administrative division of this region has been used to delimit the boundaries. The counties of Komárom and Fejer (with the exception of the environs of Dunaujuaros which belong to the region of Budapest) were used as the boundaries for the central industrial region. There is a very close production and transportation connection between the two industrial regions, it is very difficult to separate them and to reveal the objective boundary. The county boundary here essentially reflects the zone where the two regional production complexes diverge from each other.

Central Transdanubia, thus, can be broken down into three sub-regions:

1. In the sub-region of Komárom (2,851 sq. $\mathrm{km}$. and 333,000 inhabitants) coal mining and heavy industry (the aluminium, chemical, and machine building industries as well as the building material industry) located on the Danube provide the basis and main character of the regional production complex. The other industrial branches, particularly heavy industry and food processing, are not of primary importance. The structure of its industry does not differ in many respects from the sub-region of Fejer-Veszprém though they belong to different sub-regions. The differences in the industries of the two sub-regions are, first of all, differences in proportions. Coal mining is more important in Komárom than in Fejer, but in the latter metal mining, aluminium metallurgy and processing, etc. are more important in the production character and in the direction of development.

2. The sub-region of Fejer-Veszprem $(8,461 \mathrm{sq} . \mathrm{km}$. and $659,000 \mathrm{in}$ habitants) has considerable heavy industry (mining, aluminium metallurgy, machine building and the chemical industry) and has the characteristics of a regional production complex. It occupies a distinguished place among the sub-regions. Unlike the sub-region of Komárom, it is territorially less homogenous because a large part of it has an agricultural character. The proportion of the industrial workers to agricultural workers is roughly equal, 
and the number of commuting workers (who enter and leave the region for work) also is roughly equal.

The development of the bauxite mining and the production of aluminium are important in foreign trade and occupy a central place in the development of the sub-region.

Lake Balaton and its environs should also be mentioned as a microregion of the Fejér-Veszprém sub-region. It is questionable whether it can be regarded as an independent sub-region because the main character of the Balaton area is not production. It is very difficult to compare it with other regions as there is no standard to use as a basis for comparison. It has been included in the Fejér-Veszprem sub-region because the solution of the problems connected with the development and supply of the Balaton affects the region as a whole and the problems of development of the Lake Velence are similar to those of the Balaton.

3. The sub-region of Zala $(5,941$ sq. $\mathrm{km}$. and 393,000 inhabitants) is an industrially developed area of Transdanubia whose economy is based on crude oil production. This fact is reflected in the occupational structure of the population and in the high number of commuting workers. Thus, the problems of development are quite different from those of Fejèr County.

\section{THE LITTLE PLAIN}

The geographical unity of the Little Plain (8403 sq. km. and 751,000 inhabitants) is not contested. A relatively developed regional complex based on the agricultural raw material and manpower has developed here in spite of a lack of minerals and energy sources. The machine, food processing and textile industries form the main character of the region and are of national importance.

No sharp boundary can be drawn between the two sub-reigons on the Little Plain; and though in the structure of their industries, in their natural conditions, and in their agriculture there are considerable differences, the transition is almost unnoticed. The sub-regions are as follows:

1. The sub-region of Gyor ( $3,823 \mathrm{sq}$. km. and 353,000 inhabitants), has a manpower equilibrium. The proportion of workers leaving and entering the region is nearly the same due to the developed machine building. food processing, and textile industries and to the productive agriculture. The natural conditions and the economic development of the region are in harmony, and therefore its problems are related to internal developments.

2. The industrial pattern of Western Transdanubia $(4,358 \mathrm{sq} . \mathrm{km}$. and 397,000 inhabitants) differs from that of the Györ sub-region because its 
machine building industry has developed only modestly. The importance of the food processing industry, however, is grealer here than in Györ. The agricultural population exceeds the industrial population, and the number of persons leaving the sub-region for work is higher than the number of those entering. The difference, however, is not too great because the agriculture is well developed and the development of industry is in harmony with the manpower reserves.

\section{BORSOD}

The unity of the Borsod region is more obvious than that of the former regions. The region has a well-developed regional production complex, the main branches of which are mining, the production of electric energy, metallurgy, machine building, the chemical and building material industries.

In the development of the region the main emphasis continues to be on the heavy industry and on the employment of more female manpower in the auxiliary industrial branches. There also is a problem in connection with the reasonable employment of manpower because of the retraining of miners who are unemployed. The lack of water is a serious difficulty hindering the industrialization of the area.

The differences which exist in the mezo-region divide it into two subregions:

1. The sub-region of Borsod (7,247 sq. $\mathrm{km}$. and 759,000 inhabitants) is the most industrialized area of the mezo-region. It essentially includes the county of Borsod. The sub-region preserves the main character of its mezoregion, though the share of mining and metallurgy is less important while that of machine building, the chemical industry and light industry predominates. This is the most important difference on the basis of which it can be delimited from sub-reigon of Nógrád.

2. In the sub-region of Nográd (5,212 sq. km. and 506,000 inhabitants) the smaller regional production unit is based on coal mining. The main constituents of this unit are the production of electric energy, as well as metallurgy, and the building material and food processing industries. It is smaller than the sub-reigon of Borsod and differs from it in many other respects. For example, metallurgy, and the chemical industry are significant in the sub-region of Nográd, while the importance of the food processing industry is great in Borsod. The declining importance of coal mining has affected the sub-region of Nógrád much more than the subregion of Borsod. The machine building and the light industry have developed to a considerable extent in this area. 
This discussion of the sub-regions is far from complete, but it serves as an illustration of the fact that despite strong industrial centralization Hungary is differentiated by regions and regional differences that should be reckoned with both in the economic geography and the economic policy. The main task is to reveal the local conditions in order to promote a more reasonable regional distribution and development of the productive forces.

\section{BIBLIOGRAPHY}

Alampiev, P. M. and Feigin, Ju. G. (1963). A gazdasági földrajz módszertani kérdèsei (Methodological problems of economic geography). - Gazdaságfoldrajzi Dokumentáció 2. Budapest: MTA Földrajztudományi Kutatócsoport, pp 1-114.

Bora, Gy. (1964). Magyarország ipari korzetei (The industrial regions of Hungary). Kézirat. Kandidátusi èrtekezès (Manuscript. Diss.). Budapest.

Dér, E., Mrs. Zala (1964). A gazdasági alkörzetek vizsgálatainak módszerei a „KözépDunántul" peldajan (Methods of studying economic sub-regions by the example of Central Transdanubia). - Kézirat. Kandidátusi èrtekezés (Manuscript. Diss.). Budapest.

Kalasnikova, T. M. (1965). Ekonomicseszkoe rajonirovanije (The division into economic regions). - Moszkva.

Köszegi, L. (1964). A gazdasági körzetkutatas föbb elvi, módszertani es gyakorlati kèrdèsei Magyarorszagon (The main theoretical, methodological and practical problems of the research on economic regions in Hungary). - Kézirat. Kandidatusi értekezés (Manuscript. Diss.). Budapest.

Krajkó, Gy. (1961). A gazdasági korzetesités nèhány elvi problémája (Some theoretical problems of the division into economic regions). - Foldr. Kozl. 3, Vol. 9, pp 223-246.

Krajko, Gy., Penzes, I., Töth, J. and Abonyi, Gy. (1969). Magyarország gazdasági kórzetbeosztásának néhány elvi es gyakorlati kèrdése (Principles and praztice in the regionalization of Hungary). - Földr. Ert. 1. Vol. 18. pp 95-115.

Perczel, K. and Gerle, Gy. (1966). Regionalis tervezes (Regional planning). - Budapest: Akadémiai Kiadó, p 445.

Szabo, K. (1970). Területfejlesztes az uj tervidoszakban (Regional development in the new plan period). - Figyelö 38, Vol. 14. 



\section{THE TERRITORIAL DISTRIBUTION OF ENERGY}

\section{RESOURCES IN HUNGARY}

\section{A. BORAI}

Hungary is poor in energy resources. At the present rate of power production her available resources will satisfy the needs for about a hundred years. With continuous geological prospecting, however, the volume of exploitable primary energy sources (coal, mineral oil, natural gas) increases faster than production. The country's black coal, lignite and natural gas resources have been increasing at a substantially higher rate than production over the past decade. The explored wealth of crude oil is increasing at approximately the same pace as production, and the expected growth of the exploitable quantity of brown coal in Transdanubia and Northern Hungary is expected to increase parallel with production.

The volume of primary energy sources produced and imported has grown by leaps and bounds in recent years. The amount of primary energy sources has increased from 70,3 Tkcal in 1950 to $191,6 \mathrm{Tkcal}$ in 1968 - an increase of 279,6 percent.* Accordingly, the specific value of the per capita resources has risen from $7,0 \mathrm{Mkcal}$ to $19,1 \mathrm{Mkcal}^{* * *}$ The per capita consumption of solid, liquid and gaseous energy resources (Table 1) varies from one area to the next depending on the amount produced and the population living in the region concerned.

Table 1.

\section{THE TERRITORIAL DISTRIBUTION OF THE PER CAPITA PRODUCTION OF POWER}

for the vear 1965, in Mkcal per head

\begin{tabular}{lrrcrr}
\multicolumn{1}{r}{ Regions } & Solid & Liquid & Gaseous & Electric & Total \\
Budapest & 1,3 & 1,2 & 0,6 & 0,4 & 3,5 \\
Central & 0,8 & 3,9 & - & 0,8 & 5,5 \\
Miskolc & 24,7 & 0,7 & - & 2,5 & 27,9 \\
Debrecen & 0,1 & 2,6 & 4,9 & 0,1 & 7,7 \\
Szeged & 0,1 & 1,7 & 0,3 & - & 2,1 \\
Pécs & 16,3 & 12,8 & 2,2 & 0,6 & 31,9 \\
Gyór & 32,5 & 13,5 & 0,3 & 2,2 & 48,5 \\
Hungary & 11,3 & 4,9 & 1,2 & 0,9 & 18,3
\end{tabular}

* Tkcal $=$ Terra calorie $=10^{12} \mathrm{kcal}$.

** Refers to the volume of primary (coal, crude oil, natural gas) and secondary (briquette, coke, gasoline, gas oil, fuel oil, heating oil, propane-butane gas and city gas) energy carriers. 
Parallel with the increases in demands for power, the sources and utilization of the energy supply have undergone a gradual transformation. While in 1938 coal accounted for 95,7 percent of the nation's energy supply, by 1965 only 53,5 percent of the total power was provided by coal. At the same time the share of gaseous and liquid hydrocarbons rose from 4,1 to 39,4 percent, and other energy carriers increased from 0,2 to 6,1 percent.

According to Figure 1, which shows the rate of utilization of primary energy sources in calorific value (Tkcal) and in percentage, the major transformation took place in the period between 1960 and 1968. In spite of the appreciable rise in the production of coal (from 97,5 to 121,9 Tkcal) its share in the total diminished year after year parallel with the steadily increasing utilization of crude oil and natural gas.

The economic regulators introduced with Hungary's new economic mechanism had an essential role to play in the transformation of the energy balance. The capital investment allocated for hydrocarbon prospecting has grown considerably. At the same time, thanks to the new concept evolved for prospecting, the available industrial natural gas resources have increased substantially.

After the abolition of the enforced emphasis on coal mining, the consistent application of the principle of maximum profitability gradually has come to prominence. Accordingly, it was decided that all those mines where the costs exceeded the returns should be closed. As a consequence, the country's coal production has diminished.

The systematic replacement of the outdated combustion equipment relying on coal and operating at a low efficiency has begun. It involves replacement of a very considerable amount of equipment since approximately 44 percent of the boilers operating in Hungary had combustion plants more than forty years old. The conversion is hampered by the relatively small rated capacity ( 0 to 5 tons $/ h$ ) of the steam boilers set up in plants scattered over the country's territory. The situation with respect to industrial furnaces burning natural gas is much more favourable. The larger units were replaced during the second Five Year Plan period (1960-1965).

International cooperations within the CMEA has assumed an increasing role in the transformation of the energy sources and the utilization in the energy balance. For example, imports in primary and secondary energy carriers rose from 5,63 to 6,14 Tkcal between 1960 and 1968. Under the Hungarian-Soviet crude oil agreement a new refinery was erected at Százhalombatta for the vertical refining of 6 million tons of oil per year. Through the "Friendship Pipeline" approximately 2,0 to 2,4 million tons of crude oil reach Hungary from Romaskino in the Soviet Union. This amount is to increase to 4,5 million tons in the not too distant future. In the framework of international cooperation Hungary's imports increased from 5,0 Tkcal 
T.keal

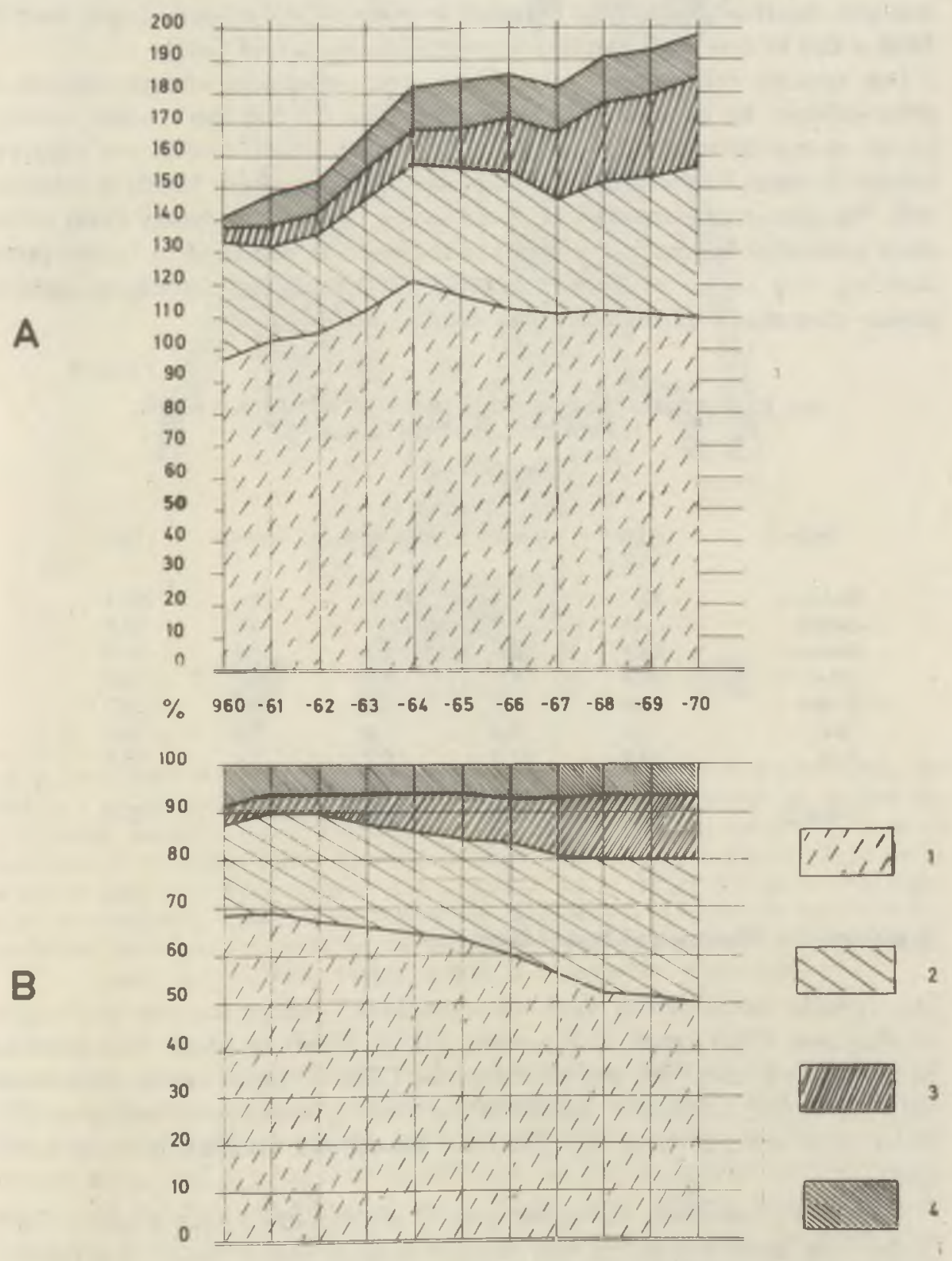

Fig. 1. The development of the primary energy source structure (1960-1968). - A) in Tkcol calorific value, and $B$ ) in percentual value. $1=$ coal; $2=$ mineral oil; $3=$ natural gas; $4=$ other energy carriers 
in 1960 to 8,9 Tkcal in 1968. In addition, in 1958 a $220 \mathrm{kV}$ transmission line was built between Bistricany, Czechoslovakia, and Zugló, Hungary. Another one was constructed in 1962 between Munkács-Sajoszöged-Zugló, and in 1968 a 400 kV line was installed between Munkács and Göd.

The specific consumption of primary and secondary energy sources is differentiated by geographic locations (Table 2). The per capita specific power consumption in Budapest (21,7 Mkcal per head) and in the adjacent industrial areas called the Central region (14,8 Mkcal per head) is substantial. The power consumption of those areas of the Hungarian Plain which were somewhat behind the rest of the country has improved in recent years. Besides, they cover an increasing ratio of the higher per capita specific power consumption from their own production.

Table 2.

THE TERRITORIAL DISTRIBUTION OF THE PER CAPITA SPECIFIC POWER CONSUMPTION IN 1965

Mkcal per head

$\begin{array}{lrrccr}\text { Regions } & \text { Solid } & \text { Liquid } & \text { Gaseous } & \text { Electric } & \text { Total } \\ & & & & & \\ \text { Budapest } & 13,5 & 5,1 & 1,5 & 1,6 & 21,7 \\ \text { Central } & 4,6 & 9,6 & - & 0,6 & 14,8 \\ \text { Miskolc } & 22,4 & 2,5 & 4,9 & 1,5 & 31,3 \\ \text { Debrecen } & 4,4 & 4,3 & 0,9 & 0,3 & 9,9 \\ \text { Szeged } & 5,9 & 1,7 & 0,4 & 0,3 & 8,3 \\ \text { Pécs } & 10,7 & 5,9 & 1,6 & 0,6 & 18,8 \\ \text { Gyốr } & 27,8 & 17,5 & 0,2 & 1,9 & 47,4 \\ & & & & & \\ \text { Hungary } & 13,7 & 6,8 & 1,4 & 1,1 & 23,0\end{array}$

\section{The Regional Structure of Power Economy}

The calorific value of the total non-cumulated energy sources in Hungary in 1968 was $239,1 \mathrm{Tkcal}, 61,2$ percent (146,4 Tkcal) of which was provided by domestic production, and 29.4 percent $(70,3 \mathrm{Tkcal})$ of which was imported. The energy sources - including the starting reserves of that year $(20,3$ Tkcal) and other sources $(2,1 \mathrm{Tkcal})$ - accounted for 22,4 percent of the total.

As Figure 2 indicates, the better part of the available heat quantity $(239.1$ Tkcal) had been converted into electric energy (135,5 Tkcal) the balance $(82,8 \mathrm{Tkcal})$ was used in its original form.

Since the expansion of the electric power producing capacities over the past decade has utilized condensing and backpressure plants, crude oil 


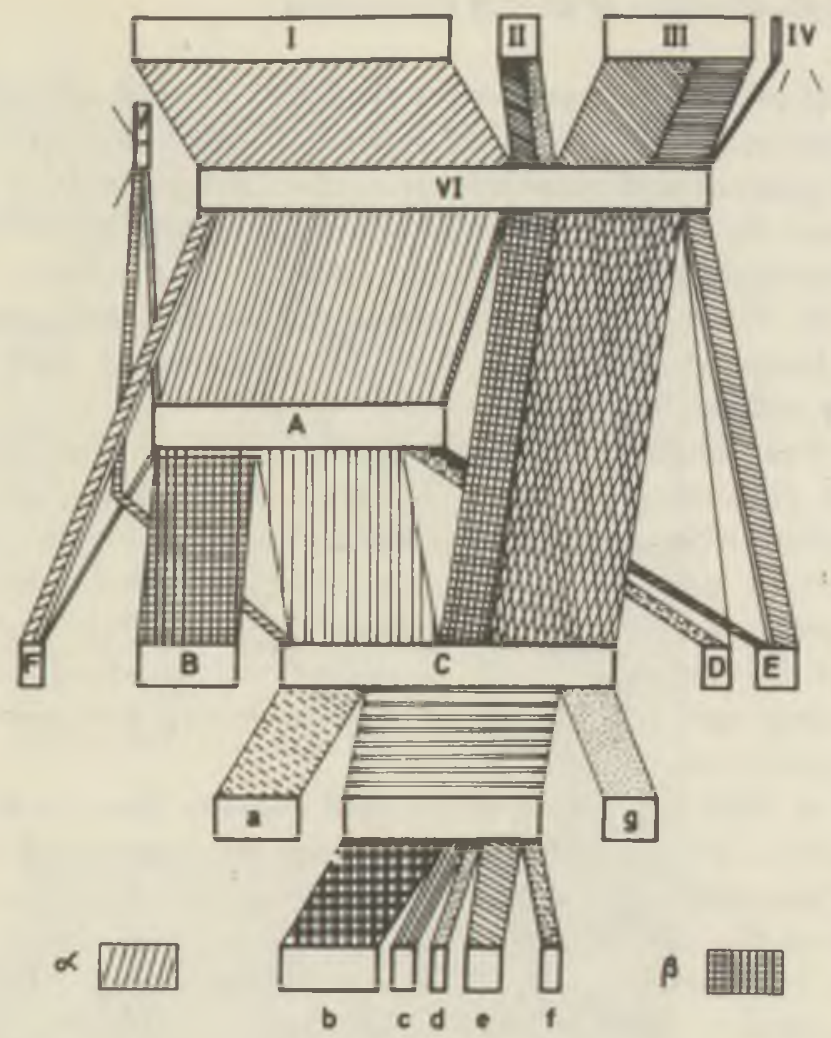

Fig. 2. Flow sheet showing the energy supply in Hungary in Tkcal calorific value, for 1968. -1 = domestic production; II $=$ reserves at year's beginning: III = imports; IV $=$ other energy carriers: $V=$ foundry gas: $V I=$ available quantity. $A=$ transformations: $B=$ transformation losses; $C=$ direct utilization; $D=$ exports; $E=$ stocks at end for year; $F=$ other division; $a=$ population; $b=$ industrial heat; $c=$ heating: $\mathrm{d}=$ non-stationary utilization for mechanical purposes; $\mathrm{e}=$ stationary utilization for mechanical purposes; $f=$ used for non energetical purposes; $g=$ used for other purposes; $\alpha=$ primary energy carrier; $\beta=$ converted energy carrier

processing, gas coal distilling and hydrocarbon cracking, the amount of energy sources used for conversion increased by approximately 22 percent. The data in the figure clearly indicate that the volume of energy used directly amounted to a total of $155,5 \mathrm{Tkcal}$. Of this converted energy carriers accounted for the greater part $(90,7 \mathrm{Tkcal})$, and primary energy sources made up the balance $(61,0 \mathrm{Tkcal})$. The demand of industry for heat $(46,3$ Tkcal) continued to play the dominant role in the utilization of this energy. Also noteworthy is the considerable demand of the population (39,1 Tkcal). The seasonal fluctuations of this demand cause difficulties in supply. 


\section{The Regional Distribution of Energy Production}

The amount of primary energy carriers produced in 1968 amounted to 146.4 Tkcal of which coal represented 62.4 percent, gaseous and liquid hydrocarbons 28.2 percent and other energy carriers 9.4 percent.

The regional distribution of the production of energy carriers can be readily differentiated also by consistency. While the coal basins in Hungary are located in the medium high ranges, the liquid and gaseous energy carriers and found along regional zones in the lowlands over terrain filled up by tertiary sedimentary strata.

There are three characteristic coal bearing areas in Hungary: Northern Transdanubia (Tatabánya, Dorog, Oroszlány, Central Transdanubia, Várpalota), Northern Hungary (Borsod, Ozd and environs, Nógrád Mátraalja), and the southern part of Transdanubia (Mecsek). Their 1968 production respectively was: 49.0 percent, 32.1 percent, and 18.9 percent. Thus, the better part of the nation's coal ( 81.1 percent) was produced in the basins along the energy axis in the south-west - north-east strike in the focus of which Budapest is situated.

From 1965 to 1968 the output of the coal industry decreased 8.7 percent. To a great extent this decline was due to the introduction of the principle of maximum profitability. In the period of the second Five Year Plan (1960 to 1965) due to the relatively high input of labour and capital on the one hand and to the relatively low returns on the other, the cost level in the coal mining industry rose from 89.6 to 96.3 percent. Later, thanks to higher average calorific values and lower ash content of the products, and through cuts in the production costs, the level once more has improved diminishing from 96.3 to 91.2 percent. Behind the average profit, however, the returns vary widely as Figure 3 indicates.

In the mines (Mátra region, Nográd, Borsod) which are operating at a loss, the greater part of the coal sold fell into the $V I$ to $X$ cost level groups. The majority of the coal produced in profitable mines was in the more favourable I to VI basins.

Coal with increased calorific value and lower ash content has assumed vital importance in recent years. However, since the value of a coal basically depends on the carbonification conditions characterizing the given geological period, the technology (grading, washing) available for improving the qualitative parameters are rather limited. In part of the Hungarian coal basins the production costs increase in proportion to the depth of working. Since, due to the widely varying stratification and tectonic conditions, concentrated, high-capacity longwalls cannot be sited. In addition. the specific costs of maintenance, transport, and air supply are disproportionately high. The mine closures greatly improved both the profitability of 


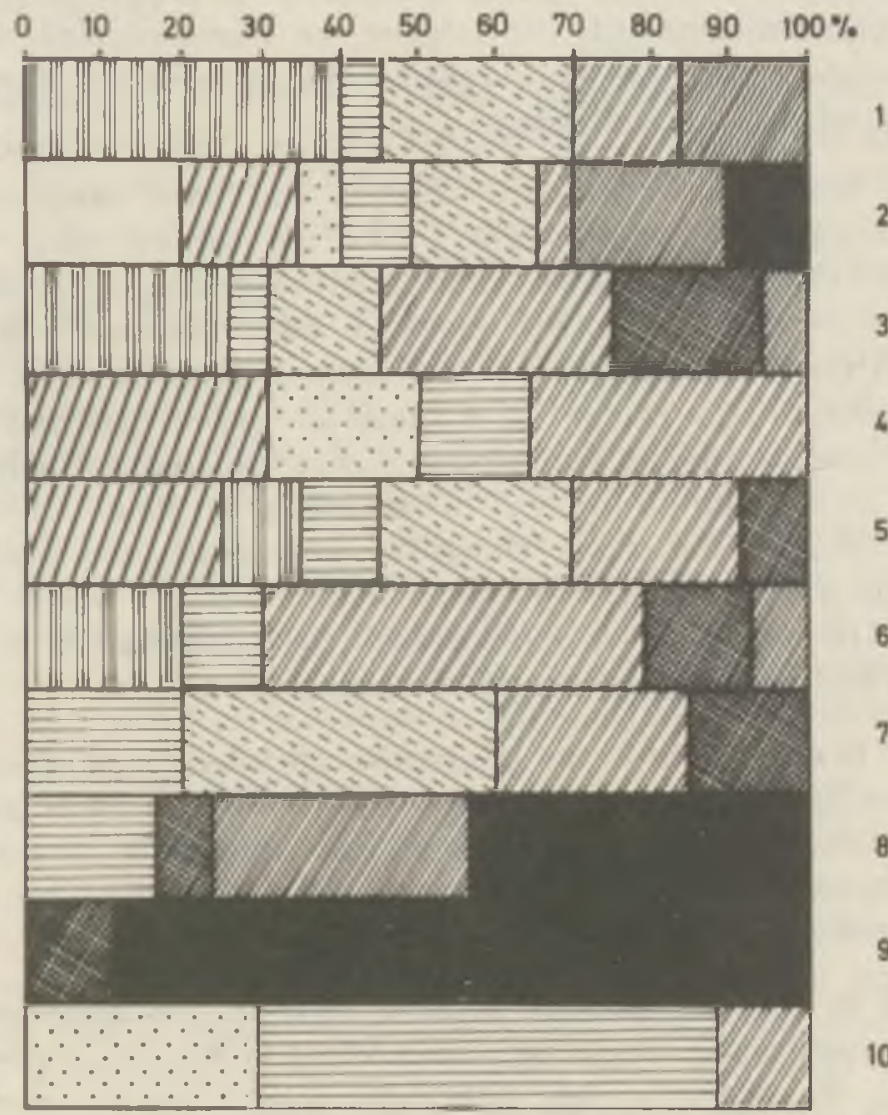

2

3

4

5

6

7

8

9

10

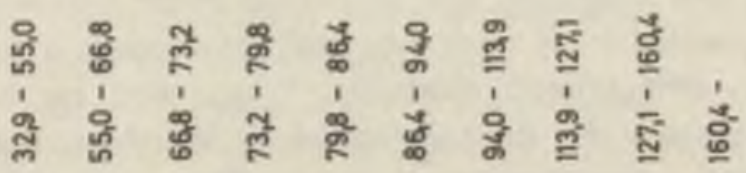

$\mathrm{K} \%$

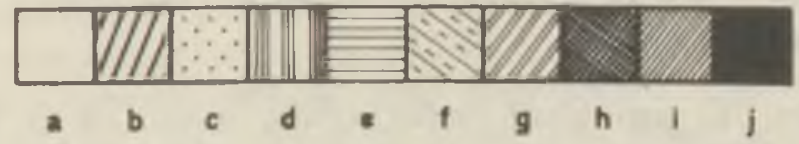

Fig. 3. Distribution of the costs of coal mining $(\%)$ for each basin in terms of percentage of production, for 1968. -1 = Mecsek; 2 = Tatabánya; $3=$ Dorog; 4 = Oroszlány: 5 Central Transdanubia; $6=$ Borsod; $7=$ Ozd and environs; $8=$ Nógrád; $9=$ Mátra and environs; $10=$ Várpalota Basin. Groups of cost percentages: $a-j$ 
the Hungarian coal mines, and owing to the endeavour to meet the qualitative demand, the volume and the regional distribution of production in the different basins also has improved. The sales of the Transdanubian basins yielding higher-grade coals have far surpassed the sales of the Northern Hungarian basins where coal is of poorer quality.

Prior to World War II, hydrocarbon production had been concentrated in the southwestern part of Transdanubia. During the second Three Year Plan period (1957-1960), however, thanks to intensive geological prospecting, increasing quantities of natural gas have been discovered in the Great Plain. With the deconcentration of hydrocarbon production, in 1960. Transdanubia produced 80.9 percent of the total of natural gas and only 19.1 percent was produced in the Great Plain and in the adjacent paleozotic basin fringe in the North. The last survey made in 1968 showed a changed picture: 94.5 percent of the Hungarian production came from the Great Plain and only 5.5 percent from Transdanubia. The shift has a great significance because the newly discovered natural gas resources are located in an area which had been industrially underdeveloped.

A similar trend is observable in the geographic distribution of crude oil production. Before 1945 Hungary could rely only on the crude oil produced in southwestern Transdanubia. In 1968 only after energetic geological prospecting, 52.7 percent of the total was produced in Transdanubia, and 47.3 percent came from the Great Plain.

A new concept in research had a decisive role in the discovery of Hungary's gaseous and liquid energy resources. While in the period preceding World War II, primarily the anticlines (characteristic geological structures at small depths and clear in configuration) were prospected, in the past decade the stratigraphic, lithological traps located at considerable depth have become the principal objectives of research. The wisdom of this new approach was confirmed when prospecting work in the Great Plain revealed crude oil and natural gas deposits is deeply buried upthrousts. terraces and seismic platforms. Prospecting for hydrocarbons has good promise since the area delimited by the Alps, the Carpathians and the Dinarides - the area where accumulations are likely - extends over some $77,000 \mathrm{~km}^{2}$.

Of the 363 geological configurations examined so far by geophysical methods, 158 also were prospected by deep drilling. Of this number, 40 percent were found to be productive. More up-to-date deep drilling technology is expected to render geological prospecting more efficient. In 1968 the drilling depths in Hungary averaged only 2,200 m. 


\section{The Regional Distribution of the Production of Secondary Energy Sources}

Briquetting, tar- and brown coal distilling plants and the condensing and backpressure plants which generate steam for power production - the major basic-material and fuel users - operate almost exclusively on coal.

The industrial thermal power stations in the service of mining (Tatabanya, Dorog, Pècsüszög, etc.) after the capacity expansions carried out at the end of the 19th century, assumed more or less the same functions which characterize the power supply stations of public utility. The Banhida Power Station established in 1936 was erected in connection with the electrification of the railway line between Budapest and Hegyeshalom, and utilized coal with a poor calorific value and considerable ash content mined locally. In the years following the economic crisis of 1935, fastexpanding bauxite and aluminium production and the aluminum processing industry made the erection of the Ajka I power station necessary. Practically on the eve of World War II, a $128 \mathrm{MW}$ capacity thermal power plant was put into operation at Budapest-Kelenföld utilizing the coals of the nearby paleoceneocen basins.

After 1945 the Mátravidék power station in Gyöngyös; the November 7 power station in Inota; the Borsod power plant in Kazincbarcika; and the ones in Tiszapalkonya, Pécs I and Ajka II were constructed. The only exception was the thermal power station of the Danube Iron Works which is located a considerable distance from the nearest coal basins. This station was located in Dunaújváros to utilize the byproducts of coal washing and other waste energies such as foundry gas. In spite of purposeful development, the fast increase of power station capacities make it necessary in some cases that the power plants have to draw their fuels from quite considerable distance, for example. Tiszapalkonya.*

The briquet production facilities at Tatabánya, Dorog, Várpalota, Nagymanyok; the tar distilling plant at Dorog; and the ahydration processing at Várpalota utilize exclusively locally produced coals.

The major centres of crude oil processing are Almásfüzitō, Szôny, Pét, Százhalombatta, Nyirbogdány. Coal distilling (Danube Iron Works), producer gas generation, hydrocarbon breakdown and mixing (city gas production) have been located at some distance from the points where they obtain their primary energy supplies. They were placed closer to the consumers and frequently were situated along the most economical transportation routes. ${ }^{* *}$

* In 1938 the public and industrial power stations (with a total capacity of $492.8 \mathrm{MWh}$ ) produced 1.4 $10^{\mathrm{ii}} \mathrm{MWh}$ of current. By 1968 this volume increased to $13.2 \cdot 10^{\mathrm{ii}} \mathrm{MWh}$.

** Except for the 700,000 tons/year capacity refinery in Zalaegerszeg which has been sited in the vicinity of the oil fields. 
A geographic survey of the 1968 output in primary and secondary energy carriers revealed that 38.8 percent $(72.1 \mathrm{Tkcal})$ of the total production had been supplied by the Györ region. Gyôr is followed by Pécs which produces 17.0 percent and Miskolc which provides 15.9 percent. The combined contribution of the less developed areas amounted to approximately 28.8 percent.

Table 3.

THE REGIONAL DISTRIBUTION OF ENERGY PRODUCTION ${ }^{a}$

in Tkcals

In 1965

\begin{tabular}{lrrrr}
\multicolumn{1}{c}{ Regions } & Solid & Liquid & Gaseous & Total \\
Budapest & 2,63 & 2,26 & 1,12 & 6,01 \\
Central & 0,74 & 3,47 & - & 4,21 \\
Miskolc & 33,22 & 0,86 & 0,05 & 33,13 \\
Debrecen & 0,06 & 3,90 & 7,35 & 11,31 \\
Szeged & 0,05 & 2,38 & 0,54 & 2,97 \\
Pécs & 21,11 & 16,55 & 2,89 & 40,55 \\
Gyór & 57,53 & 20,50 & 0,59 & 78,62 \\
& & & & \\
Total & 115,34 & 49,92 & 12,54 & 177,80
\end{tabular}

In 1968

$\begin{array}{lrrrr}\text { Budapest } & 1,99 & - & 1,52 & 3,51 \\ \text { Cenfral } & 0,68 & 17,10 & 0,22 & 18,00 \\ \text { Miskolc } & 29,11 & 0,58 & 0,07 & 29,76 \\ \text { Debrecen } & 0,05 & 3,99 & 14,42 & 18,46 \\ \text { Szeged } & 0,02 & 7,98 & 6,66 & 14,66 \\ \text { Pécs } & 19,72 & 11,64 & 0,81 & 32,17 \\ \text { Gyór } & 53,64 & 18,04 & 0,44 & 72,12 \\ \text { Total } & & & & \\ & 105,21 & 59,33 & 24,14 & 188,68\end{array}$

${ }^{a}$ The figures in the table are cumulated values.

The energy carrier output of the regions has changed substantially between 1965 and 1968, as Table 3 indicates. The output of the most productive regions (Miskolc, Pécs, Gyôr) diminished, while that of formerly backward regions (Szeged, Debrecen and the Central region) increased appreciably. Table 3 shows that in the case of Debrecen and Szeged the increase was due to a rise in the production of hydrocarbons while in the case of the Central region, the increase was attributable to the processing of the crude oil imported from the Soviet Union. 
The output of the Gyorr, Pécs, and Miskolc regions is decreasing due mainly to changes in the production structure. In Budapest, for example, the Pesvidéki Briquet Factory and the Csepel plant of the Danube Crude Oil Enterprise changed from large to smaller-scale production. At the same time most plants consuming very large amounts of heat were removed from the metropolitan area and resituated in less developed areas of the Great Plain. In addition, to reverse this trend new large plants have been put into operation in some areas such as the Central region.

\section{The Utilization of Energy Resources}

The primary and secondary energy sources utilized in the course of 1968 totalled 240.3 Tkcal. Their territorial distribution is shown in Table 4 and Figure 4

Table 4.

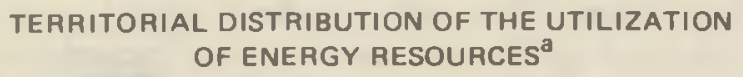

\begin{tabular}{lrrrr}
\multicolumn{1}{l}{ Regions } & Solid & Liquid & Gaseous & Total \\
Budapest & 26,52 & 9,96 & 2,99 & 39,47 \\
Central & 3,91 & 8,19 & 0,05 & 12,15 \\
Miskoic & 30,08 & 3,44 & 6,67 & 40,19 \\
Debrecen & 6,61 & 6,52 & 1,42 & 14,55 \\
Szeged & 8,59 & 2,38 & 0,61 & 11,58 \\
Pécs & 13,78 & 7,57 & 2,16 & 23,51 \\
Gyôr & 49,19 & 30,99 & 0,31 & 80,49 \\
& & & & \\
Total & 138,68 & 69,05 & 14,21 & 221,94
\end{tabular}

$\ln 1968$

$\begin{array}{lrrrr}\text { Budapest } & 23,88 & 7,95 & 7,43 & 39,26 \\ \text { Central } & 4,16 & 26,16 & 2,85 & 33,17 \\ \text { Miskolc } & 26,28 & 4,39 & 8,92 & 39,59 \\ \text { Debrecen } & 6,68 & 7,19 & 1,03 & 14,90 \\ \text { Szeged } & 7,55 & 3,31 & 1,27 & 12,13 \\ \text { Pécs } & 12,78 & 5,67 & 0,88 & 19,33 \\ \text { Gyór } & 46,98 & 32,52 & 2,41 & 81,91 \\ \text { Total } & 128,31 & 69,05 & 24,79 & 240,29 \\ & & & \\ \text { The figures in the table are cumulated values. }\end{array}$




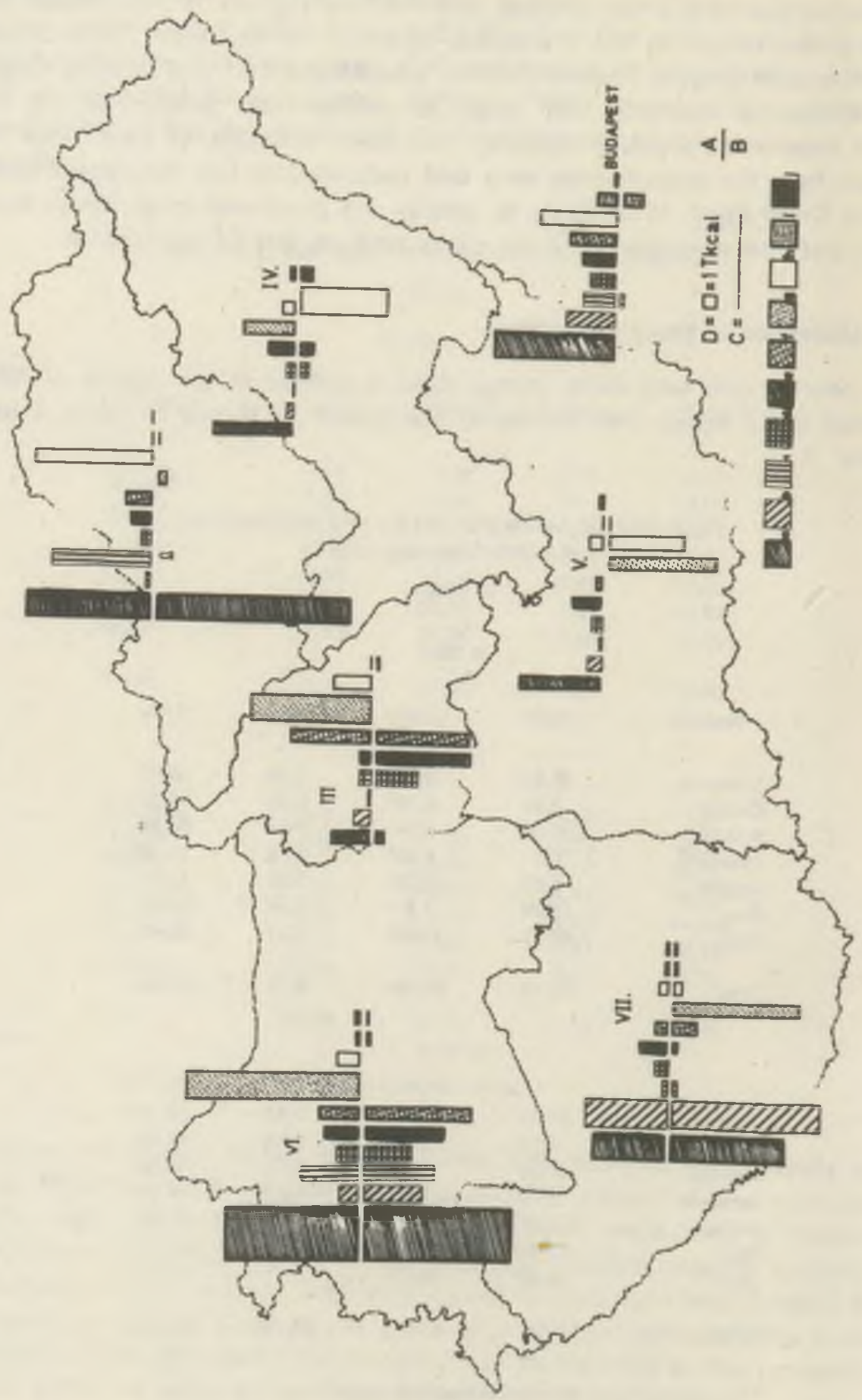


The Györ region, which in 1968 consumed 34.2 percent (81.9 Tkcal) of the total energy consumption of Hungary, became the country's major energy utilizing area. Györ is followed by Miskolc which consumed 16.6 percent (39.6 Tkcal). With its large heat demand (39.3 Tkcal) Budapest is third on the list. Fourth is the Central region around the capital (33.2 Tkcal). Budapest and the Central region's share in the national total was 30.0 percent. The Pécs region which holds the second place in production (19.3 Tkcal) was the fifth in power consumption using 8 percent of the total. In spite of increasing hydrocarbon production, the consumption of the Debrecen (14.9 Tkcal) and Szeged (7.5 Tkcal) regions is less than expected. The heat demand of the Great Plain was as low as 11.2 percent of the national whole. Thus, it is obvious that the demand for energy carriers is concentrated along the south-west-north-east energy axis where 80.8 percent of the total is utilized by the major industrial consumers situated along the Hungarian Mountains.

On the basis of Tables 3 and 4 the power balance of the individual regions (the difference between output and utilization) can be readily determined. In spite of the large imports (15.2 Tkcal) in the Central region and in spite of considerable intraregional energy reserves of the Gyor and Miskolc regions ( $9.8 \mathrm{Tkcal}$ and $9.8 \mathrm{Tkcal}$ respectively), these areas are deficient in power supplies and must resort to imports. It is noteworthy that between 1965 and 1968 the consumption of the main power producing regions diminished simultaneously with the slow transformation of the consumption structure. In addition, a drop in the utilization of intraregional coal, briquet and coke, the utilization of the extraregional natural gas and the more or less intraregional crude oil products has risen due to factors such as increasing communications and population.

The regions which still are backward in utilization of energy (Debrecen, Szeged) use less of the intraregional energy resources than would have been expected. The relatively small and deconcentrated thermal demand of the industrially less developed lowland areas impedes the local utilization of natural gas. The routing of the natural gas pipelines, therefore, benefits those regions (Miskolc, Györ) which have a significant coal wealth of their own.

Fig. 4. Territorial distribution of the production and utilization of energy carriers, in 1968. - I = Budapest; II = Miskolc; III = Central; IV = Debrecen; V = Szeged; $\mathrm{VI}=$ Gyốr; VII = Pécs; $\mathrm{A}=$ utilization in Tkcal; $\mathrm{B}=$ production in Tkcal; $\mathrm{C}=$ region's boundaries: $D=0.5$ Tkcal; $a=$ coal; $b=$ briquet; $c=$ coke $d=$ mineral oil; $e=$ patrol; $f=$ gas and fuel oil; $g=$ heating oil; $h=$ natural gos; $i=$ city gas: $\mathrm{j}=$ propane-butane gas 


\section{BIBLIOGRAPHY}

Országos Energiagazdálkodási Hatóság Energiagazdálkodási Statisztikai Évkónyve (Statistical Yearbook of Energy Economy of the National Board for Fuel and Power Economy). - Budapest (1966, 1967, 1968).

Borai, A. (1968). A kōszènértèkesitèsi körzetek kialakitásának metodikai problêmái (Methodological problems of forming coal marketing districts). - Dunántúli Tudományos Gyüjtemény 84. pp 1-32. (Series Geographica 38).

Borai, A. (1970). A magyarországi foldgáztermelès ès értékesitès foldrajzi problémái (Geograpical problems of Hungarian natural gas production and its utilization). Földr. Ért. 4, Vol. 19, pp 393-408.

Borai, A. (1970). A szénbányászat rentabilitásának terúleti elemzèse (Territorial analysis of rentability of coal-mining). - Földr. Ért. 3, Vol. 19, pp 289-302.

Cukor, Gy. and Sági, M. (1964). Az energiaszūkséglet ès tóvlati tervezèse (Energy demand and long-range planning). - Budapest.

Dank, V. (1968). A hazai szénhidrogénkutatások eredményei (Results and tasks of hydrocarbon prospecting in Hungary). - Földtani Közlöny 1, Vol. 98, pp 3-15.

Dank، V. (1969). A kóolaj- és foldgázkutatás helyzete Magyarországon (Research of crude oil and natural gas in Hungary). - Magyar Tudomány 10, pp 623-632.

Kertai, Gy. (1962). A magyarországi fōldgảztelepek kialakulásáról ès továbbkutatósuk alapelvérôl (On the genesis of petroleum). - Földtani Közlöny 1, Vol. 92, pp 274-279.

Körössy, L. (1963). A magyarországi kỏolaj- ès földgáztelepek elhelyezkedésének nẻhány tôrvényszerúsége (Distribution of oil and natural gas in Hungary). - Foldatani Kozlöny 1, Vol. 98. pp 20-27.

Lévai, A. (1969). Az energiaellátás távlati tervezésének módszerei és tudományos problè.mai (Methods and scientific problems of the perspective planning in energy). Magyar Tudomany. Uj folyam 6, Vol. 14. pp 363-373.

Markos, Gy. (1962). Magyarország gazdasági foldrajza (Economic geography of Hungary). - Budapest: Közgazdasági Kiadó.

$\mathrm{Az}$ energiahordozók közötti választás gazdasági irảnyelvei (Economic principles of choice among the eniergy carriers). - Kézirat (Manuscript). Budapest: Országos Müszaki Fejlesztési Bizottság. (1964 jun.) 677/1964 sz. tan.

Radó, S. ed. (1963). Magyarország gazdasági foldrajza (Economic geography of Hungary). Budapest: Gondolat. 


\section{SOME ECONOMIC GEOGRAPHICAL. PROBLEMS OF HUNGARY'S CHEMICAL INDUSTRY}

\section{Z. ANTAL and GY. PERCZEL}

The increasing economic importance of the chemical industry can be regarded as a world-wide phenomenon in recent years. Through an increasing reliance on chemicals principally by the use of hydrocarbons in the chemical industry the national economy has gained a larger raw material base. This industry also has had a great effect on labour productivity, of which the agricultural use of chemical substances is especially illustrative. The development of the industry has had a share in the transformation of the power economy and in the advancement of numerous other industries (e.g., communication and metallurgy). In addition, by producing consumer goods, it exerts a direct influence on improving the living standards.

Due to these facts, the chemical industry became one of the preferred branches of the Hungarian economy. Between 1950 and 1969, 14.7 percent of the total investment was expended on the development of the chemical industry, while only 18.1 percent was assigned to mining.

The rapid progress of the chemical industry, however did not only mean quantitative increases in production, but also a structural transformation and a regional modification of production.

\section{The development of the Hungarian chemical industry}

In the past twenty years the chemical industry has shown an average development pace of 14.5 percent yearly, almost twice the growth rate for that of industry as a whole. In 1970 the total production value of the chemical industry was one and one-half times as high as it was in 1938. Table 1 shows some indices that represent the development of chemical industry as a whole.

The data representing the development of the chemical industry are more impressive when compared to the development of the other branches of industry. Chemicals account for nearly 10 percent of the gross industrial production, and with 100,000 workers they have become one of the fundamental branches of the Hungarian economy. Table 2 shows the increases in production since 1949. The articles listed in the table generally represents the most dynamic branches of the industry. 
SOME IMPORTANT INDICES OF THE DEVELOPMENT OF THE CHEMICAL INDUSTRY

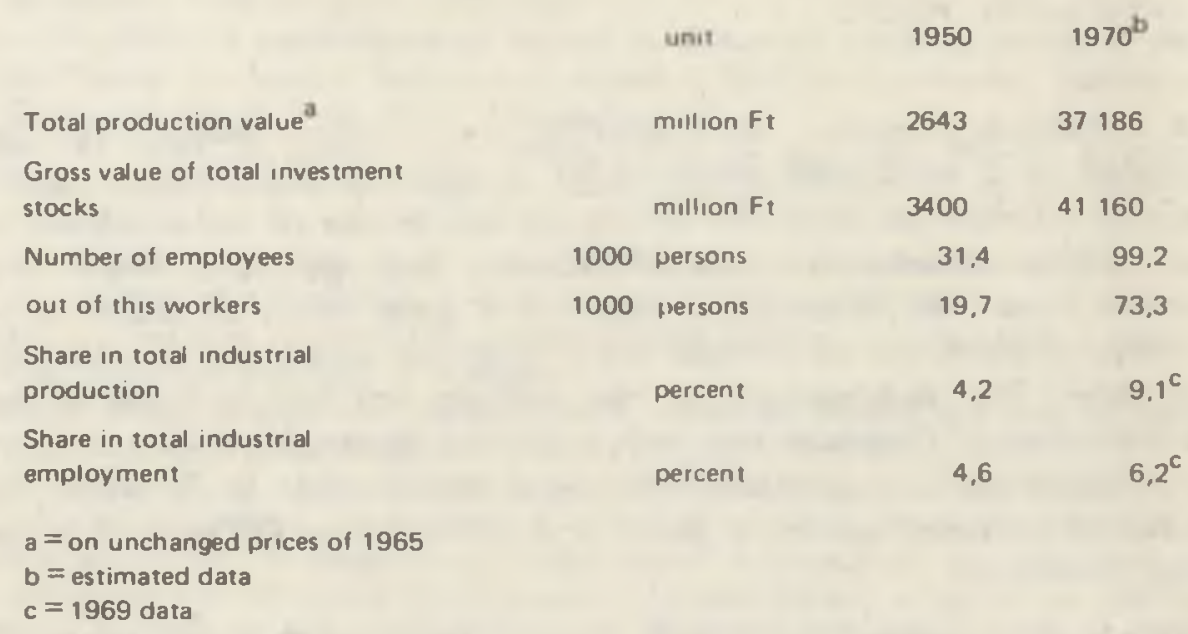

Table 2.

PRODUCTION TRENDS IN THE MORE IMPORTANT CHEMICAL PRODUCTS

unit $\quad 1949 \quad 1960 \quad 1970^{\circ}$

Nitrogenous manure

(in effective agent)

1000 tons

11

145,3

340

Phosphorous manure

(in effec (Ive agen I)

1000 tons

15

116,3

173

Synthetic materıal

Synthetic fibre

tons

1400

30000

65000

Refined oil

tons

2319

6500

10420

Sulphuric acıd

1000 tons

473

3830

6000

1000 tons

49

370

440

Insecticides and pesticides

(in effective agent)

tons
kılogram

1100

12080

16000

Crude morphıne

Chlorocide

kilogram
tons

4800

13300

10000

Automobile tıres

1000 pieces

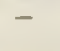

190

320

Truck tires

1000 pieces

$-31$

200

280

40

370

440

$a=$ estimated data 
These results primarily are due to the realization of principles that won acceptance during the 1960s. Subsequent to World War II, three separate concepts provided guidelines for Hungary's chemical industry. Between 1945 and 1949, the country's resources only permitted reconstruction after the war. By the end of this period, production value increased by 70 to 75 percent as compared to that of 1938 . This growth can be regarded as a significant achievement.

In the period between 1950 and 1960 the problems which affected Hungary's national economy affected the chemical industry too. Autocratic trends in economic policy were partly responsible for the basing of the chemical industry on coal. The direct consequence of these policies led to an imbalance in the structure of production. It also must be mentioned, however, that during this period a number of extremely important plants which served as bases of the further development of chemical industry (Borsod Chemical Works, Hajduság Pharmaceutical Factory, the plant for discontinuous polyamid fibre production of the Nyergesújfalu Viscosa Works) were constructed.

During the period beginning in 1960, international division of labour and the conditions of Hungary's national economy offered new opportunities for the chemical industry. The essence of the new principles of development can be summed up as an emphasis on development of the chemical industry on the basis of petrolchemistry by the utilization of the hydrocarbon supplies of Hungary.

\section{Structural transformation of chemical industry}

The quantitative growth of chemical industry went hand in hand with the structural transformation of this branch of the economy. Table 3 depicts the structure of chemical industry.

These data make it obvious that more than 80 percent of Hungary's chemical industry is concentrated in four branches: production of other organic and inorganic chemical products, oil refining, pharmaceutical industry, and rubber and synthetic materials manufacture. These branches are the most dynamic in the industry. This classification, however, does not refer to a number of facts that show the current role and situation of the individual branches of manufacturing. Table 4 details the percentage of the total production of chemical industry provided by the various branches.

These data plainly indicate which sectors of the industry are developed and which branches call for an urgent improvement. Keeping in mind the branch structure of the chemical industries of highly developed countries, and taking into account the endowments of Hungary, it is obvious that the 
Table 3.

STRUCTURE OF CHEMICAL INDUSTRY IN 1966

\begin{tabular}{|c|c|c|c|c|}
\hline Branch & $\begin{array}{l}\text { Gross value } \\
\text { of fixed } \\
\text { assets } \\
\text { (in million } \\
\text { Fts) }\end{array}$ & $\begin{array}{l}\text { Number of } \\
\text { emplovments } \\
\text { (in persons) }\end{array}$ & $\begin{array}{l}\text { Total } \\
\text { production } \\
\text { value } \\
\text { (in million } \\
\text { Fis) }\end{array}$ & $\begin{array}{l}\text { Production } \\
\text { index } \\
1960=100\end{array}$ \\
\hline 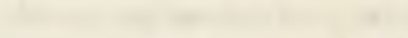 & 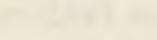 & & & \\
\hline Oil refining & 3053 & 5121 & 5249 & 169,4 \\
\hline Gas manufacture & 2862 & 5798 & 1392 & 143,5 \\
\hline Coal manufacture & 1314 & 2472 & 1413 & 143.4 \\
\hline Pharmaceutical industry & 3079 & 16521 & 4358 & 343,5 \\
\hline Varnish industry & 373 & 1657 & 1021 & 197,3 \\
\hline Cosmetics and detergents & 200 & 2246 & 727 & 118,5 \\
\hline Rubber and synthetics & 2481 & 22893 & 3658 & 222,9 \\
\hline $\begin{array}{l}\text { Production of other organic and } \\
\text { inorganic chemical products }\end{array}$ & 12044 & 32568 & 7613 & 250,4 \\
\hline Total & 25406 & 89276 & 25431 & 214,8 \\
\hline
\end{tabular}

Table 4.

SHARE OF INDIVIDUAL BRANCHES IN THE TOTAL PRODUCTION OF THE CHEMICAL INDUSTRY

Product

Artificial manure

Insecticides and pesticides

Production of synthetic materıals

Synthetic materıats manufacture

Chemical gas production

Detergents, household chemicals

Production of organic and inorganıc basic materials

Varnish industry

Pharmaceutical industry

Rubber industry

Total

$a=$ estımated data
$1950 \quad 1960 \quad 1970^{a}$

percent

$\begin{array}{rrr}16,5 & 13,0 & 18,2 \\ 0,1 & 3,4 & 4,0 \\ 2,8 & 2,0 & 3,2 \\ 5,9 & 2,3 & 3,4 \\ 5,0 & 3,0 & 3,0 \\ 9,4 & 7,8 & 2,7\end{array}$

$\begin{array}{lll}39,0 & 25,1 & 22,6\end{array}$

$7,8 \quad 6,6 \quad 6,0$

$\begin{array}{lll}4.9 & 17.0 & 20,4\end{array}$

$\begin{array}{lll}8,6 & 19,8 & 16,5\end{array}$

$100,0 \quad 100,0 \quad 100,0$ 
main deficiency of the industry is the very low synthetic material and fibre production. These branches have already shown production shares of 6 to 15 percent in the most developed countries as against the 3 percent shown in Table 4, and it would be this proportion by which we could attain the world standard of per capita consumption in synthetical materials and fibres. Furthermore, in the future greater attention must be paid to the production of detergents and varnishes.

Finally, mention must be made of the dynamic development of the rubber industry and especially of the pharmaceutical industry. The pharmaceutical industry has, in fact gained an international reputation for its high quality products.

\section{Geographical distribution of the chemical industry}

The quantitative development and structural tarnsformation of the chemical industry went hand in hand with some regional relocation. The provincial plants have long been preferred by new investments in order to diminish the concentration of the chemical industry in the capital. The decentralization, however, has met whith limited success, as the data in Table 5 indicate.

Table 5.

NUMBER OF EMPLOYMENTS IN THE CHEMICAL INDUSTRY

\begin{tabular}{|c|c|c|c|}
\hline Region & $\begin{array}{c}1957 \\
\%\end{array}$ & $\begin{array}{c}1960 \\
\%\end{array}$ & $\begin{array}{c}1970^{\mathrm{a}} \\
\%\end{array}$ \\
\hline Budapest & 59,0 & 57,8 & 51,2 \\
\hline Baranya County & 1,2 & 1,4 & 1,4 \\
\hline Bács-Kiskun County & 0,4 & 1,5 & 1,6 \\
\hline Borsod-Abauj-Zemplén County & 4,6 & 9,6 & 11,3 \\
\hline Csongrád County & 2,2 & 3,2 & 1,0 \\
\hline Fejér County & 2,0 & 2,2 & 1,6 \\
\hline Gyór-Sopron County & 1,3 & 1,2 & 1,4 \\
\hline Hajdu-Bihar County & 2,3 & 2,1 & 2,5 \\
\hline Komárom County & 7,4 & 5,0 & 5,0 \\
\hline Pest County & 2,4 & 3,0 & 4,3 \\
\hline Szabolcs-Szatmár County & 1,6 & 1,8 & 1,6 \\
\hline Szolnok County & 1,0 & 0,8 & 1,5 \\
\hline Veszprém County & 12,3 & 11,7 & 13,6 \\
\hline Others & 2,3 & 2,6 & 2,0 \\
\hline Total & 100,0 & 100,0 & 100,0 \\
\hline
\end{tabular}

$a=$ estimated data 
The capital's share in chemical industry is due partly to the economic historical and political situation which affected the location of industry during the consolidation of capitalism and during the inter-war period. Until 1945 the chemical industry of Budapest principally had a light industrial and packaging character. After World War II reconstruction and new investments somewhat modified this character, but the development that started in the 1960s, scarcely touched the regional structure of production. On the contrary, the prominent role of Budapest has been stabilized because maximum outputs with minimum inputs can only be realized there.

In the chemical industry, the decentralization of the last twenty years was realized by the location of base plants in the provinces which in the future can reduce the predominance of the capital. That is to say, the new chemical works of the provinces produce basic products or products of high volume (artificial manure, sulphuric acid etc.). while the bulk of the more profitable and labour-intensive branches of the light chemical industry (e.g., the pharmaceutical industry) are found in Budapest.

Currently Veszprém and Borsod-Abaúj-Zemplén counties have highly developed industries. However, both counties only possess a few chemical factories of national importance. The chemical centres of Veszprem County are Várpalota (Pét Nitrogen Works), Balatonfüzfó (nitrokemia) and Peremarton (Industrial Explosives Factory). In Borsod-Abaúj-Zemplén County the following factories are located: Leninváros (Tisza Chemical Works). Sajóbábony (North-Hungarian Chemical Works) and Kazincbarcika (Borsod Chemical Works).

It is worthy iof note that the functional decay of Komarom County is in connection with the declining importance of the coal chemical industry. On the other hand, the relatively quick development of Pest County is due to the oil refinery at Százhalombatta. The major part of sulphuric acid and phosphorous manure is produced in Szolnok where the production of detergents and pulverous paint also is significant.

During the next ten years the share of the provinces will increase further, especially in Borsod-Abaúj-Zemplén County where the construction of a forty billion forint petrolchemical complex soon will be started. It will represent the largest investment of Hungary's national economy to date.

The following section of this study will discuss in more detail the two most important branches of the industry: oil refining and pharmaceuticals.

\section{Oil refining}

Oil refining, one of the most dynamic branches of chemical industry, has a history of 100 years in Hungary. Its role was decisive in the structural transformation of the power economy and in the establishment of the 
petrolchemical basis of chemical industry. Its growth results from either the regression of other industries (e.g., coal mining, coal chemistry etc.). or with the introduction of more economical technologies. Oil refining has an influence on the regional and international division of labour, encourages new cooperations, and provides new incontives for the regional localization of productive forces.

\section{DEVELOPMENTAL TRENDS AND GEOGRAPHICAL LOCATION \\ OF OIL REFINING}

The enlargement and intensification of international division of labour among the Comecon countries, and the research about hydrocarbons has led to considerable changes in the oil refining industry.

The increases in production, shown in Table 6 , were necessitated chiefly by the structural transformation of power economy, and these requirements will be maintained for the next 10 to 15 years.

Table 6 .

DEVEL.JFMENT OF OIL REFINING

\begin{tabular}{|c|c|c|c|c|}
\hline & unit & 1950 & 1960 & $1970^{2}$ \\
\hline Capacity of oil refineries & million rons & 0,92 & 2,68 & 6,5 \\
\hline Quantity of refined oil & million tons & 0,48 & 2,58 & 6,0 \\
\hline $\begin{array}{l}\text { Number of workers employed } \\
\text { in oil refining }\end{array}$ & 1000 heads & 2,58 & 3,89 & 6,42 \\
\hline $\begin{array}{l}\text { Per capita quantity of } \\
\text { refined oil }\end{array}$ & ton per head & 189 & 664 & 950 \\
\hline
\end{tabular}

$a=$ estimated dale

The development of oil refining is based on the conceptions that emerged at the end of the 1950s. It is necessary to emphasize this point since treaties with the USSR which assured a long-range supply of oil were concluded at the time. The fundamental principles of development prefer the location of new refineries instead of expanding them by reconstruction, as the older refineries are located at sites which generally are disadvantageous from the viewpoint of the regional division of goods. At the same time, these principles call for construction of large, complex refineries.

These principles have been realized in the reconstruction of the Komárom Petroleum Company, and especially in the establishment of the 
Danube Petroleum Company which fulfils a special function and therefore deserves a more detailed discussion. In 1962 this plant was opened in Százhalombatta, $30 \mathrm{~km}$. from Budapest. It receives its raw material through the "Friendship Pipe Line" that starts from the USSR. The site of the plant was fixed by the possibility of saving 20 to 30 percent of investment costs required by the large scale of the plant and the minimum costs of transport. In addition, this location made possible the construction of the $600 \mathrm{Mw}$. Százhalombatta thermal power station operated with petroleum products. At the present time one distillery with a one million ton capacity and another one with a two million ton capacity are operating there with numerous subsidiary workshops. A distillery of three million tons is under construction and will be put in operation in 1972.

At present the refinery of Százhalombatta makes up one-half of the total production of the Hungarian oil refining industry while the other half of it is divided among five refineries of four oil companies. Table 7 gives detailed data about each of these refineries.

Table 7 .

PRODUCTION OF OIL REFINING COMPANIES

(in million tons)

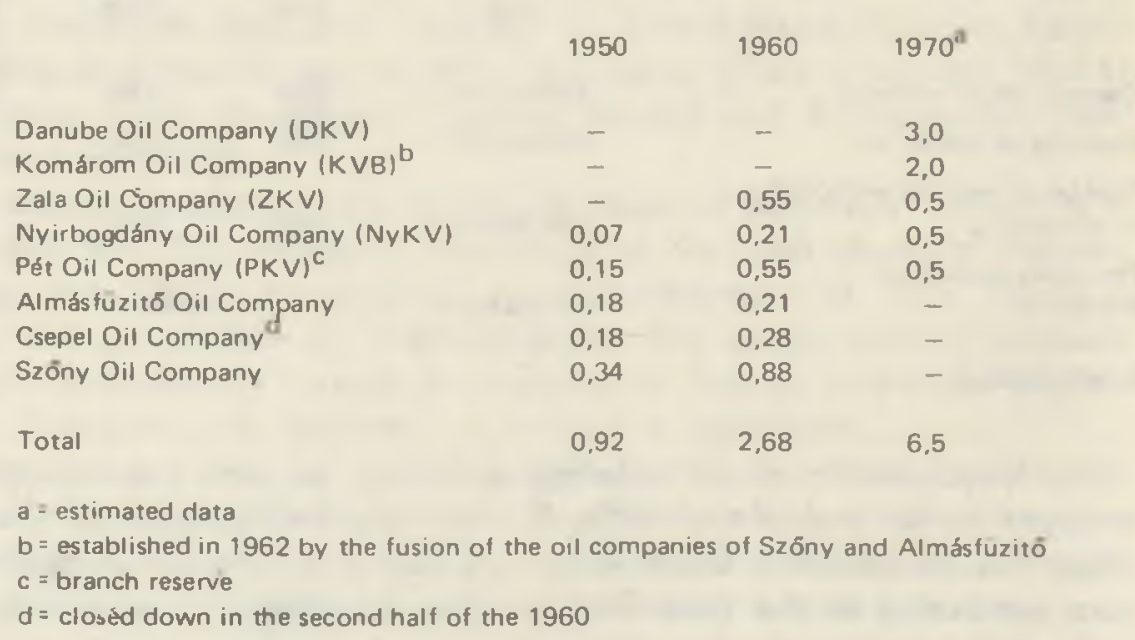

There exists a regional localization of oil refineries. To the east of the Danube (the major part of the country) there is only one relatively outdated refinery operating with a small capacity; the others are located in Transdanubia. Their sites were determined either by local factors, or by the interests of certain capitalist companies (the former proprietors), except 
for the location of the Zala and Danube Oil Companies which were put in operation after World War II and are exceptions to this general rule.

By the end of the 1970s considerable changes will have taken place in the capacities and regional location of oil refineries. The Danube Oil Company's schedule is a capacity of six million tons by 1972, and the Leninvaros refinery will have a six million ton capacity when it is put into operation in 1977. Through the construction of an oil-product-pipeline an optimum distribution will be feasible.

\section{OIL SUPPLY OF THE REFINERIES AND THE STRUCTURE OF THE PRODUCTION}

During the first decade that followed the end of World War II, our plants for the most part refined Hungarian oil. Investive development could be realized only when oil import was started within the framework of longrange interstate treaties. At the present time about 70 percent of the refined oil is imported from the USSR. The bulk of it arrives through the "Friendship Pipe Line" starting from the region between the Volga and Ural rivers. Hungary's oil production totals nearly two million tons, and more and more of it is coming from the district of Szeged. As a result, a pipeline has been constructed connecting Algyõ with Százhalombatta. Previously, the centre of production was localized in the district of Nagylengyel (Southwest Transdanubia). Due to the difficulties in transporting the extremely viscous oil with a bitumenous base, the Zala Oil Company was located near the oil field in Zalaegerszeg. A branch of the pipeline also starts from Nagylengyel and runs as far as Devecser. It provides the raw materials for the Pèt, Komárom and Danube Oil Companies. Some smaller oil fileds which supply the Nyirbogdany refinery have been opened on the Great Plain and near Eger. In 1971 construction of the "Friendship !!" pipeline will begin. Starting out from the USSR and touching Leninvaros on the way, it eventually will reach Szazhalombatta. By the end of the 1970s it will provide an annual capacity of ten million tons.

The regional locations of Hungary's oil fields, hydrocarbon pipeline systems and refineries are shown in Figure 1.

The wider use of oil products and the intensive quantitative increase of oil production have resulted in a considerable modification in the structure of refining.

The production rate of the individual products is determined by market demands and the quality of the refined oil. In previous decades the principal task was fulfilling the needs of "white goods" (gasoline, petroleum). Today, however, the demands are mostly for heavier fractions. It must be 


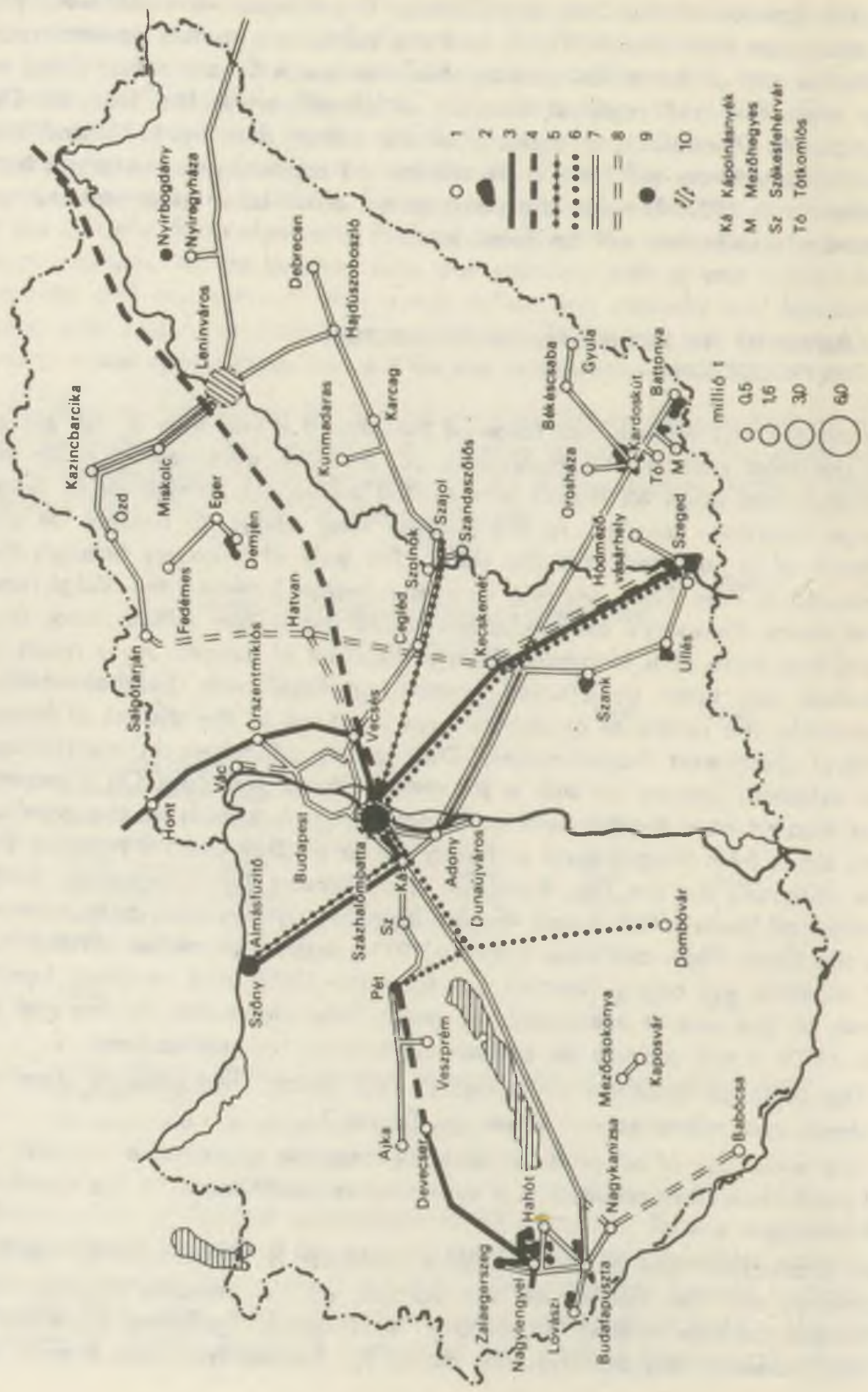


mentioned that the recent past can be characterized by a boom in gasoline production. The rapidly growing number of cars require a higher octane gasoline, while the low octane gasoline is used in the chemical industry (ethylene production, gas manufacture etc.). Currently, diesel oil and fuel oil are the most demanded articles both in the European and in the Hungarian comes of this branch make up twelve billion Forints, while the net profit markets. The former is used in gariculture and communication, and the latter in home heating. Bitumen production also has increased considerably. At present, some 60 excellent sorts of bitumenous products are being produced in the refineries of Hungary.

In the oil refinery production structure a prominent role is given to the needs of Hungary's foreign trade partners. Hungary has traditional oil product markets in Western Europe (Austria, German Federal Republic and Switzerland) which have absorbed more than one millon tons of gasoline, diesel oil, fuel oil and bitumen in 1969. Although the Mediterranean pipelines and the refineries built on these pipelines decreased the demand for the Hungarian oil products, the closing of the Suez Canal restored the demand.

Finally, it is worthwhile to refer to the nationally significant profits accumulated by oil refining. According to the targets for 1970, the gross incomes of this branch make up twelve billion Forints, while the net profit of it will amount to approximately four billion Forints.

Table 8.

\section{TREND OF THE STRUCTURE OF REFINEMENTS}

(In 1000 tons)

\begin{tabular}{|c|c|c|c|c|}
\hline th & 1949 & 1960 & $1970^{a}$ & $\begin{array}{c}\text { Index } \\
1970 / 1949\end{array}$ \\
\hline Gasolene & 179 & 329 & 954 & 5,3 \\
\hline Diesel oil & 105 & 697 & 1640 & 15.6 \\
\hline Heating oil & - & $\ldots b$ & 170 & - \\
\hline Fuel oil & 32 & 988 & 2310 & 72.2 \\
\hline Bitumen & 16 & 315 & 495 & 30,9 \\
\hline Lubricating oil & 21 & 118 & 168 & 8,0 \\
\hline
\end{tabular}

Fig. 1. Regional location of the oil fields, the hydrocarbon pipeline system, and the oil refineries of Hungary. Compiled by G. Perczel. $-1=$ settlements; $2=$ oil fields; $3=$ oil pipeline: $4=$ projected oil pipeline; $5=$ oil product pipeline; $6=$ projected oil product pipeline; $7=$ natural gas pipeline; $8=$ projected natural gas pipeline; $9=$ oil refinery: $10=$ projected oil refinery 


\section{The pharmaceutical industry}

The pharmaceutical industry, one of the most important branches of Hungary's chemical industry, enjoys an international reputation. More than 90 percent of its present capacity is due to the improvemens effected after 1945. The industry itself possesses some unique features:

1. It uses small volume of materials and its finished products have a small volume.

2. Its products have a very high value when compared to their small volume. Therefore even intercontinental distances do not limit their sale.

3. It has large requirements for qualified labour.

4. Research institutes and clinics decisively influence the location of pharmaceutical factories.

Due to these features the pharmaceutical industry fits well in Hungary's national economic plans that prefer the development of the production of less material intensive products of high value employing a large amount of qualified labour.

\section{DEVELOPMENT AND LOCATION OF THE PHARMACEUTICAL INDUSTRY}

The pharmaceutical industry has developed more rapidly than the chemical industry as a whole.

The present level and structure of production evolved during three periods. From 1949 to 1959 some 670 millon Forints were invested in the modernization of this industry and in the construction of a new pharmaceutical factory, Biogal, in Debrecen. Between 1960 and 1965 the pharmaceutical factories of Budapest were reconstructed and expanded at an investment cost of 1.7 billion Forints. Between 1965 and 1970 there was an investment program of 2.6 billion Forints for reconstructing the provincial factories and producing intermediary and base materials. All of these investments are stabilizing the prominent role of pharmacetutical industry, and at the same time are providing a favourable base for further development.

The per capita production value shown in Table 9 call attention to the fact that this branch of the chemical industry has shown a rapid advance in technical level. This fact and the growing international demands for these products are responsible for the national significance of the pharmaceutical industry. During the second Five Year Plan, 1.7 billion Forints were invested in this industry. On contrast, this branch contributed 11 billion Forints to the gross national product. 
TREND OF SOME MORE IMPORTANT INDICES OF PHARMACEUTICAL INDUSTRY

\begin{tabular}{|c|c|c|c|c|}
\hline & Index & 1950 & 1960 & 1969 \\
\hline & t & 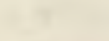 & 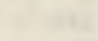 & \\
\hline Total production value & $1950=1.00$ & 1,00 & 11,08 & 45,90 \\
\hline Number of employments & $1950 \quad 1,00$ & 1,00 & 3,12 & 4,76 \\
\hline $\begin{array}{l}\text { Per capita production } \\
\text { value }\end{array}$ & $1950 \quad 1.00$ & 1,00 & 3,53 & 9,43 \\
\hline
\end{tabular}

About 90 percent of the pharmaceutical industry is concentrated in Budapest (Chinoin Factory of Pharmaceutical and Chemical Products, United Pharmaceutical and Food-Preparation Factory, Köbánya Pharmaceutical Factory). As a result of the provincial investments discussed previously. however, the share of the capital will drop to 80 percent in the 1970s. Any perceptible change in the regional localization of pharmaceutical production can only be attained by the location of a new factory in the districts of Pècs and Szeged.

In the last few years the share of several provincial plants in the production of intermediary and base materials (Sajóbábony, Fûzfö. Tiszavasvari, Dorog), has been increasing, as has the packaging functions of the Budapest plants.

\section{PRODUCTION PROFILE AND PHARMACEUTICAL EXPORTS}

Due to the manifold outputs of production it is difficult to determine the production profiles of the individual pharmaceutical plants, however, production traditions have bound each product group to a particular factory.

The Alkaloid Chemical Factory of Tiszavasvár takes a prominent place in the wold for manufacture of crude morphine and other narcotics. In Debrecen, the Biogal Pharmaceutical Factory produces antibiotics. The most important pharmaceuticals produced by the Budapest factories are: medicines for nervous diseases and inflammations as well as vitamins and hormone preparations.

This industry produced 530 specialty items in 1969, and put its 1500 varieties into circulation. The chemical industry provides 97 percent of Hungary's pharmaceutical needs. However, only 30 to 35 percent of the total pharmaceutical production was needed in Hungary, 65 to 70 percent of it was exported.

Hungary occupies the tenth place in the world's pharmaceutical industry. In export volume it is the third country in the world and the seventh or eighth in total export trade. During the past twenty years Hungary's 
pharmaceutical export increased 130 times. Packaged pharmaceutica! exports brought in 900 million exchange rate Forints in 1969, or about 4 percent of the total export trade.

The export trade in pharmaceuticals is determined first by the efficiency of the products. Each specialty necessitates the production of more than a thousand compounds, and the testing of each. All this effort requires a great research apparatus. The new products of good quality have a monopoly until the production out of a more efficient one, therefore, research and the development of new products are of special importance in pharmaceutical industry. The results of the last ten years in this area are manifested by the production of 10 to 20 new base materials and 20 to 40 new products every year. More then 1600 persons are employed in research and development of which more than 25 percent belongs to the technical staff.

\section{BIBLIOGRAPHY}

Antal, Z. (1969). Magyarország iparföldrajza (Industrial geography of Hungary). - Budapest: Tankönyvkiadó.

Antal, Z. (1967). A kōolaj- és szénfeldolgozás gazdasảgföldrajzi kèrdèsei Magyarországon (The economic-geographical problems of petroleum and coal processing in Hungary). - Földr. Ért. 2, Vol. 16.

Antal, Z. and Perczel, Gy. (1965). A földgàz gazdasági hasznositása Magyarországon (The economical utilization of mineral gas in Hungary). - 1, Vol. 14.

Antal, Z. (1967). A területi-gazdasági kapcsolatok változása a bŏvített üjratermelés során a szervetlen vegyipar ès acélipar példajón (The transformation of regional-economic relations in course of the expanded production cycle repeated annually as reflected by the inorganic chemical and steel industry respectively). - Földr. Ert. 1, Vol. 16.

Kóródi, J. and Márton, G. (1969). A magyor ipar területi kèrdesei (Regional problems of Hungarian industry). - Budapest: Kossuth Kiado.

Kóródi, J. (1967). A magyar ipar területi elhelyezkedèsènek ès településének sajátossága: (Some features of the regional settling and location of industry in Hungary). - Foldr. Ért. 2, Vol. 16.

Szekér, Gy., Szerb, F. and Bontó, L. (1965). A magyar vegyipar helyzete ès fejlesztése (Condition and development of Hungarian chemical industry). - Budapest: Közgazda. sági Kiadó.

Magyar Statisztikai Zsebkönyv (Hungarian Statistical Pocket-book). - Budapest: Statisztikai Kiadó Vállalat (1970).

Statisztikai Évkönyv 1949-1950 (Statistical Yearbook). - Budapest: Statisztikai Kiadó Vállalat (1969). 


\section{REGIONAL CHANGES IN HUNGARIAN AGRICULTURE}

\section{T. BERNAT}

This study is aimed at answering some fundamental questions concerning the regional and general development of Hungarian agriculture during the last thirty years. These questions are as follows:

1. How did Hungary's agricultural production and its geographical distribution change?

2. How were the changes reflected by the regional specialization and concentration of cgricultural production?

\section{General Trends in Agricultural Production}

After World War II Hungarian agriculture has lagged behind the industrial development of the country. While in 1969 industry grew more than twofold, and there is a more than threefold increase in national income from its prewar level, the total production value of agriculture only exceeded the average of 1934 to 1938 by 40 percent. The volume of national income produced by agriculture only surpassed its prewar level by about 10 percent.* A superficial comparison of these data would lead us to the statement that Hungarian agriculture is stagnating, and that it is no longer significant in the nation's economy.

The moderate indices of development, however, conceal the unparallelled efforts expended in the field of agriculture in order to do away with centuries old backwardness, poor technical equipment, and lack of skilled labour. Despite the vigorous efforts, 25 years have not been enough to completely reconstruct the agricultural system after the grave war damages (a loss of 750 million dollars). In addition, the marked changes which took place after World War II - the democratic land reform of 1945 and the socialist transformation of agriculture (1959-1961) - released new productive forces but caused many difficulties at the same time. Other significant reasons for the modest development of agriculture are:

1. A permanent and considerable land decrease (from the prewar 7.6 million to 6.9 million hectares) which primarily affected crop production.

2. A serious decrease in the agrarian population. In 1969 some 1.4 million workers - 700,000 less than in the prewar years - were employed in agriculture. A considerable change also took place in the age composi-

* Applying the unchanged prices of the year 1959. 
tion of the agrarian population. In the 1930s only 15 percent of the farm workers was more than 60 years of age, whereas now 44 percent belongs to this age group.

3. A lack of sufficient new investments between 1950 and 1956. In the early 1950 s nearly all investments were devoted to the expansion of heavy industry, and agriculture's share was only 10 to 13 percent of the total. Texation and the price control system allowed only a minimum accumulation of profit.

By and large, agricultural outputs have followed the changes of agricultural policy. Even after the prewar level was attained in 1951, production still fell below this level several times. Starting in 1957, however, production has exceeded the averages of 1934-38 each year. During the last 5 years agricultural production has risen above its prewar level evenly and permanently.

The decrease in the active agrarian population - despite the disadvan. tages of its age composition - resulted in a significant change in labour productivity. In 1969 the agricultural production of one agricultural worker was twice as high as it was before World War II.

\section{Changes in the Geographical Distribution of Agricultural Production}

The gross production value of Hungarian agriculture* increased by 14 billion Ft. during the last 30 years (between 1935-39 and 1962-66).** The different regions and counties contributed to this increment at different rates.

The maximum rate of growth occurred in the Great Hungarian Plain where there was a 44 percent increase. In Northern Hungary (counties of Borsod-Abaúj-Zemplèn, Heves and Nógrád) there was an average rate of growth of 35 percent and in Transdanubia a less than average 29.5 percent increase. As a consequence, the share of the macro-regions in the coun-

* Henceforth abbreviated GPV. GPV at county level calculated by the Regional Department of the Central Statistical Office in 1968, served as basis for the analysis of regional changes. Unfortunately, the regional data of some branches for the basic period (1935-1939) ware not available. Among the lacking data those of poultry-breeding would have been the most important. The branches that could be included within the calculations make up some 80 percent of the total agricultural production. The data are sufficient for drawing conclusions relating to the changes in regional proportions. Similarly, due to calculation difficulties, regions were broken down only to counties (considering the actual county boundaries), and there was no possibility of analysing the great divergencies within the regions themselves. Nevertheless, the trends of development of the macro-regions manifest themselves by a specification according to counties.

** This result of calculations of the Central Statistical Office that shows a 37 percent increase in comparison with the two periods as a summation of county calculations is in accordance with the actual data of the afore-mentioned nation wide evaluations, 
try's agricultural production has changed. Although these changes were not enormous, they were fairly significant in that they increased the significance of the Great Plain (from 48.3 to 50.7 percent) and diminished that of Transdanubia at the same time (from 40 to 37.6 percent) (Figure 1)

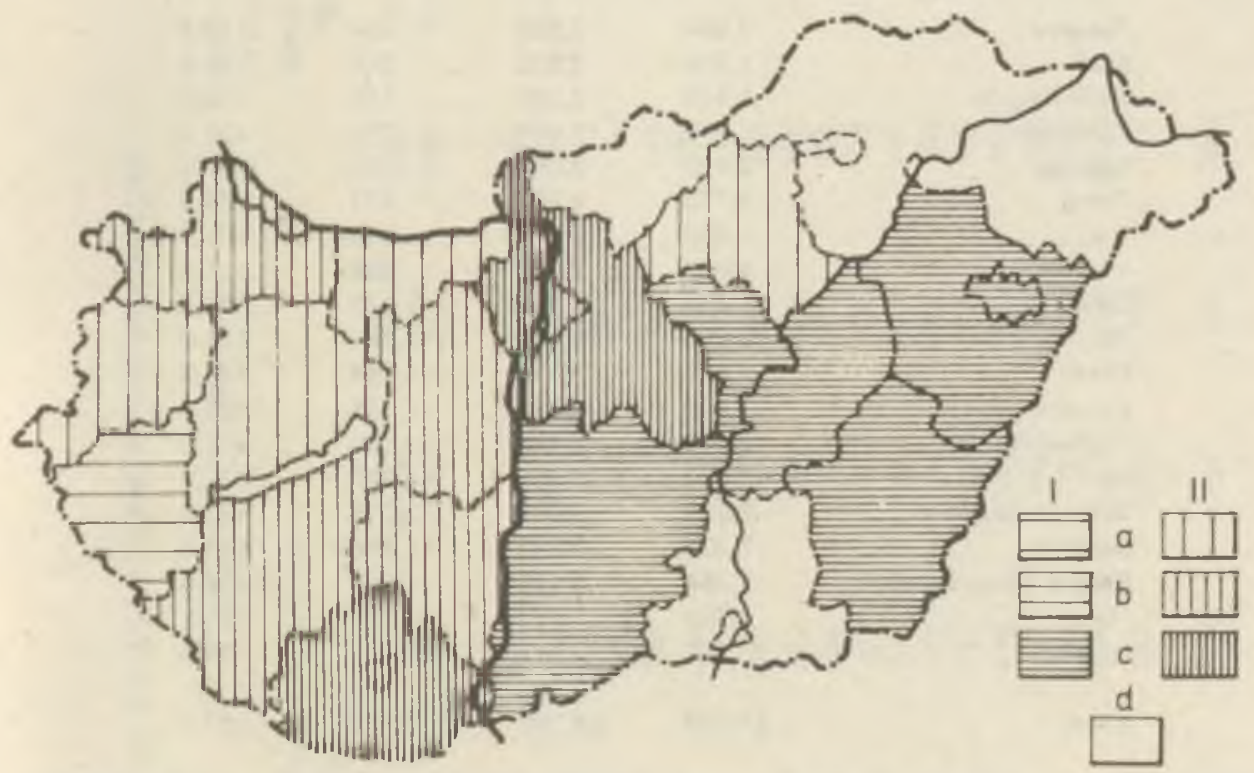

Fig. 1. Changes in the shares of the counties in the GPV of agriculture (1935/3919:2/66). $-1=$ increase; $11=$ decrease. $a=$ slight; $b=$ average; $c=$ considerable: $d=$ stagnant

Investigating the regional distribution of changes by counties, it becomes obvious that the maximum growth almost coincides with the most important agricultural counties. In contrast to the average growth rate of 37.3 percent, production increased by 59 percent in Hajdu-Bihar and Békés counties, by 52 percent in Szolnok, and by 46 percent in Bács-Kiskun County. These four counties yield 39 percent of Hungarian agricultural production, and they led other counties in growth rate too (Table 1).

Since the agricultural areas of the counties are of different sizes, the GPV of each 100 cadastral yokes of agricultural area also was examined. Using this determinant the Great Plain was at a disadvantage at its extensive areas with sandy or alkali soils are not arable. It is significant, however, that the same four counties stand first in development of production level. While the per unit area GPV increased by 49 percent for the country as a whole. Hajdu-Bihar County increased 73 percent, 
Table 1 .

INCREASE OF THE GROSS PRODUCTION VALUE OF AGRICULTURE

\begin{tabular}{|c|c|c|c|c|}
\hline Count & $\begin{array}{c}\text { GPV } \\
\text { Million Ft } \\
1935 / 39\end{array}$ & $\begin{array}{c}\text { GPV } \\
\text { Million Fit } \\
1962 / 66\end{array}$ & $\begin{array}{l}\text { Difference } \\
\text { Million Ft }\end{array}$ & $\begin{array}{c}\text { Index } \\
1935 / 39 \\
100\end{array}$ \\
\hline
\end{tabular}

\begin{tabular}{|c|c|c|c|c|}
\hline Baranya & 2,064 & 2,528 & +464 & 122.4 \\
\hline Fejèr & 1,956 & 2,532 & + 576 & 129.4 \\
\hline Gyỗr Sopron & 1,756 & 2,252 & 496 & 128.2 \\
\hline Komărom & 779 & 1,031 & 252 & 132.3 \\
\hline Somogy & 2,408 & 3,064 & 656 & 127.2 \\
\hline Tolna & 1.773 & 2.250 & 477 & 126.9 \\
\hline Vas & 1,303 & 1,716 & - 413 & 131.7 \\
\hline Veszprem & 1,630 & 2,138 & +508 & 131,2 \\
\hline Zala & 1,263 & 1,812 & + 549 & 143,5 \\
\hline Bács-Kıskun & 3,396 & 4,958 & $+1,562$ & 146,0 \\
\hline Bếkes & 2,465 & 3,919 & $+1,454$ & 159,0 \\
\hline Csongrảd & 2,136 & 2,912 & +776 & 136,3 \\
\hline Hajdu-Bihar & 2,241 & 3.565 & $+1,324$ & 159,0 \\
\hline Pest & 2,892 & 3,620 & +728 & 125,2 \\
\hline Szabolcs-Szatmár & 2,678 & 3,694 & $+1,016$ & 137,9 \\
\hline Szolnnk & 2,226 & 3,374 & +1.148 & 151,6 \\
\hline Borsod Abauj-Zemplén & 2.264 & 3,136 & + 872 & 138,5 \\
\hline Heves & 1,360 & 1,786 & +426 & 131,3 \\
\hline Nógrád & 749 & 1,011 & +262 & 135,0 \\
\hline Total & 37.339 & 51,298 & $+13,959$ & 137.3 \\
\hline
\end{tabular}

Békés County increased 63 percent, Szolnok had a growth rate of 62 percent and in Bács-Kiskun County the rate was 56 percent (Table 2).

During the last 30 years the labour force decreased somewhat faster than decreases in agricultural lands. Comparing labour force with the prewar times, it diminished by 75 percent until 1965. The regional changes of labour force per unit of land between 1930 and 1965 are shown in Table 3.

During the period from 1930 to 1965, the proportion of agricultural labour on each 100 cadastral yokes decreased from 19.6 to 12.5 percent on a national average. Examining this question at a county level, Transdanubia (counties of Zala. Fejerr and Györ-Sopron) experienced an overaverage decrease.

The four counties of the Great Plain that take the lead in the GPV increase, also reflect the scale of nation-wide alterations by the changes in their per unit area agrarian population. At present none of the four counties considerably exceeds the national mean. Even Szolnok and HajdúBihar show an underaverage labour supply in relation to land size. Thus, it follows that labour supply per land unit did not play a prominent role in the growth of production. 
$\frac{v}{5}$

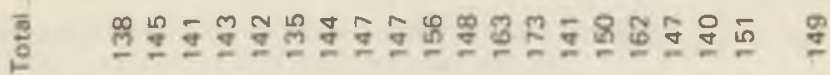

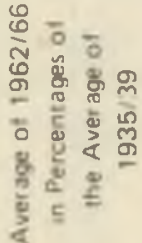

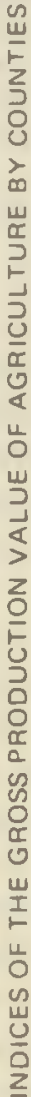

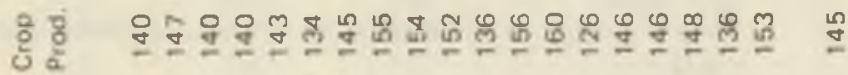

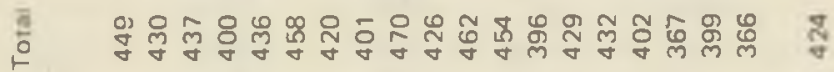

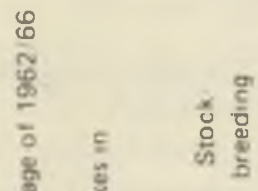

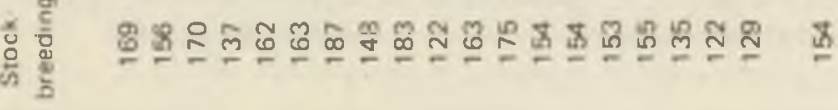
पे

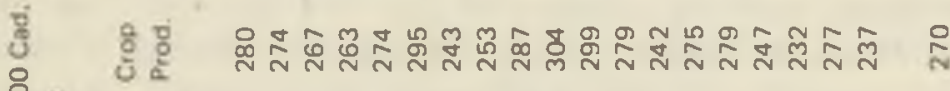
음

용 ำ

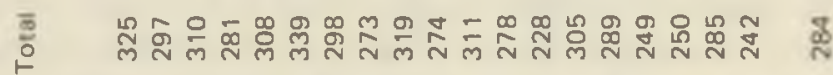
을 듬

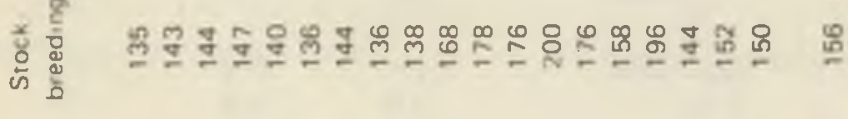

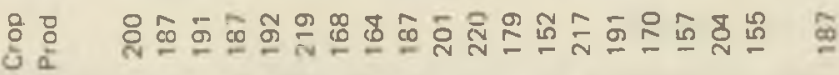

$\frac{2}{5}$

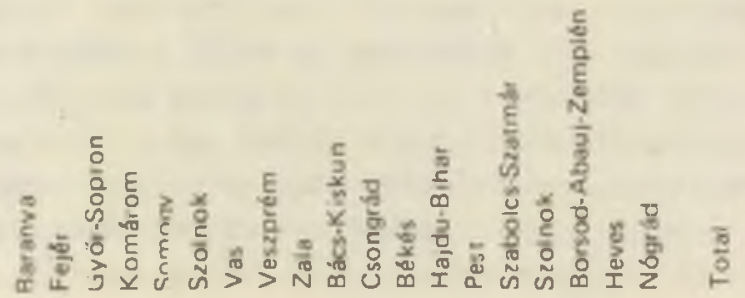


NUMBER OF AGRICULTURAL WORKERS PEH 100 CADASTRAL YOKES OF CULTIVATED LAND BY COUNTIES ${ }^{a}$

County

$\begin{array}{ll}1 & \text { Bacs-Kiskun } \\ 2 & \text { Bekes } \\ 3 & \text { Fejer } \\ 4 & \text { Györ-Sopron } \\ 5 & \text { Heves } \\ 6 & \text { Komarom } \\ 7 & \text { Szabolcs-Szatmar } \\ 8 & \text { Szolnok } \\ 9 & \text { Zala } \\ & \\ & \text { Total }\end{array}$

1930

21,4

17,8

14,0

18,8

25,1

16,0

18,8

17,5

31,0

19.6
1949

22,2

19.6

16.1

20,0

24,9

15,3

24,7

18.8

30.9

21,3
1960

1965

216

17.5

12.5

16.1

21,3

12,6

23.5

13,9

26.3

18.4

13,8

12,0

6.9

8,3

14,0

10,5

15.0

9,0

14.6

12.5
$1930100 \%$

65
67

49

44

56

65

78

51

48

64

${ }^{a}$ County data are represented by 9 counties that showed a minimum regonal change in the period under examination, making thus comparson possible.

The nation-wide decrease in agricultural population by approximately one-third, and the increase of the GPV by more than one-third means that there has been a nearly 100 percent increase in labour productivity. This increase indicates that there has occurred considerable technical progress in Hungarian agriculture.

In addition to the simultaneous diminutions of land and labour, the growth in production has required an increasing utilization of industrial goods and products especially after 1960 . In 1969, some $120 \mathrm{~kg}$. of artificial fertilizer in effective substance were used on each hectare of arable lands, orchards and vineyards. There also was a tenfold increase in tractor stock as compared to the prewar years. In 1969 there were 67,000 tractors in Hun. gary, and more than 80 percent of the total traction power is mechanized.

There have been a number of consequences of the regional changes outlined above:

The differences in the agricultural production levels of the counties has increased, the dispersion of values has become more marked. However, the differences are not particularly great, especially in comparison to the regional divergencies in industrial level. Counties with the maximum and minimum level differ only by \pm 20 percent from the national average. The highly developed agricultural areas coincide, though not necessarily, with the industrially underdeveloped ones. One reason for this distribution is that while the industrial regions for the most part are energy orientated, energy production is linked with the Hungarian Mountains which have a limited agricultural potential. These opposite tendencies of industrial and 
agricultural levels in the regions lessen the level differences present in general economic development. Taking the per capita national income produced by industry as a basis, the extreme values obtained as a result of the examination at county level show a difference of $1: 10$; on the other hand, this value is only $1: 1.38$ if the basis taken into consideration is the total national income produced by industry and agriculture together.

\section{Changes in the Regional Structure of Agricultural Production}

Both correlation calculations and general international experiences show that the most important determinant of agricultural level is the structure of production, or specialization. During the last 30 pears the progress in specialization has not been sufficient and this fact has been a decisive cause of the slow development of Hungarian agriculture.

The economic policies of the last decades produced adverse conditions for regional specialization as a whole. In the thirties regional specialization was hindered by the existing system of land ownership. The smallholder traditions of subsistence farming survived. Due to the chronic shortage of capital even most of the large estates were not up-to-date, capitalist, large-scale farms, and were only weakly specialized. However, in some parts of the country where capitalist, small-scale farms were found in the greatest number and semi-feudal restrictions were not present (e.g. Danube-Tisza Interfluve), region specialization came into being in conformity with the physical conditions and market demands alike.

During World War II, the economic boom effected the modernization of agriculture and parallel with it, the intensification of agriculture's regional specialization, mainly in the production of industrial crops. The structure of production was limited by delivery obligations, but it allowed a certain conformity to the geographical conditions by the substitution of similar products.

The democratic land reform of 1945 multiplied the universal smallholdings and did not encourage regional specialization. In addition, the agricultural specialization and forced collectivization of the fifties did not permit evolution of a reasonable regional specialization. The compulsory rotation-plans often failed to consider regional conditions. For example, in the mountainous regions nearly as much grain had to be produced as in the supply-belt of Budapest, or on the territory east of the river Tisza. Furthermore, in Hungary's special physical conditions, market gardening plays a prominent role and it is particularly sensitive to insecure economic policy. 
Although large-scale farming has become predominant in the last ten years, it has not increased specialization either. Large farms in general have preserved the smallholders' structure of production. Subsistence farming and needs of employment stimulated the farms to pursue diversified farming. It is also true that specialization is hindered by the shortage of capital, because existing resources have been dissipated unreasonably and investments have not been utilized efficiently.

Even though the regional specialization of agriculture has been retarded by a number of handicaps, some changes have taken place. The changes in the regional structure of agriculture are summarized in the following sections.

1. With some exceptions the changes in the regional structure contributed to the decline of specialization. Thus, a levelling of the different regions was experienced in almost all branches of stock-breeding." The maximum decrease in grain production took place in the formerly most productive region (Central Tisza Region), however, the minimum decrease was experienced in the physically most adverse areas (Nógrád. Borsod, and Veszprem counties). Maize production grew mainly in those regions which are the least suitable for its production (Vas, Zala, Komarom, and Borsod counties), but it lagged behind in the traditional production regions (Szolnok, Hajdú, Fejér counties), etc.

2. The specialization that had developed earlier under the influence of the local markets grew indistinct. This trend is particularly obvious in the vegetable and milk supply belt of Budapest. Within the actual administrative boundaries of Budapest, the proportion of cows in the total livestock was 91.7 percent in 1935 and 34.7 percent in 1962. In 1939 some 77.4 percent of the vegetables sold on the Budapest markets were produced in her suburbs while in 1965 this figure had declined to 13 percent. Budapest, the largest consumers' market of Hungary. could not affect the development of agriculture in her suburban area and as a consequence, in the last 30 years Pest County was next to the last among the counties in the growth of production. The potential advantage of the location of this area was minimized by the territorially uniform prices, and local marketing was hindered by a number of administrative directives.

Since the main form of development in the food industry was the expansion of capacity of existing plants, their material supply regions extended enormously. Therefore, freight charge, have risen and a number of other problems have developed.

The actual crop production regions and markets were rather neglected by the location of new food processing plants. Consequently, the average

* See page 205 for a detailed discussion. 
transport distance of vegetables rose above 200 kilometres, while the average transport distance for canned products is 255 kilometres.

In the highly developed countries the big slaughterhouses and coldstorages are decentralized, however, in Hungary they were centralized, and thus there are higher freight charges and considcrable weight loss in transport.

Although the large-scale farms now produce the same kinds of crops as the former small farms did, it would be an error to equate the structures of production of the two farm types. Our co-operative farms allow an upto-date production scale of several kinds of products simultaneously. Even in the future specialization in one or two products is not being envisioned. Instead, as an initial step, it will be necessary to abandon the production of crops that show a deficit due to the local circumstances of the cooperatives.

3. The regional concentration of the different branches of production also depends on the development of specialization. Concentration implies that the production of a crop is concentrated in that region where physical or economic conditions particularly favour it. It follows from the previous discussion of regional specialization that the regional concentration of production did not intensify considerably in the period under examination (Figure 2). The changes of concentration in the individual branches can be summarized as follows:

The regional concentration of bread grain production did not change. This branch can be characterized like it was in the prewar years, by a low degree of concentration. There does not exist a single county that could produce more than 10 percent of the nation's bread grain or any district that could produce two percent of it. Twenty districts each contribute one to two percent of the total crop. yielding about a quarter of the total bread grain production.

The geographical distribution of fodder crops likewise is even. Three counties (Békés, Bács-Kiskun and Szolnok) produce approximately onequarter of the total fodder crops just like they did 30 years ago. A more vigorous concentration is shown in the production of maize, however.

Potato production is more concentrated than the crops discussed previously and its level of concentration on the whole remained unchanged. The proportion of the three largest potato producing areas (SzabolcsSzatmár, Somogy and Pest counties) increased from 37 to 38 percent. The Nyirség Region that yielded a quarter of the total potato production earlier, today scarcely produces more than 20 percent of it. A considerable part of potato production is widely dispersed.

Although the former intense regional concentration of industrial crops weakened somewhat, these crops still can be considered somewhat con- 


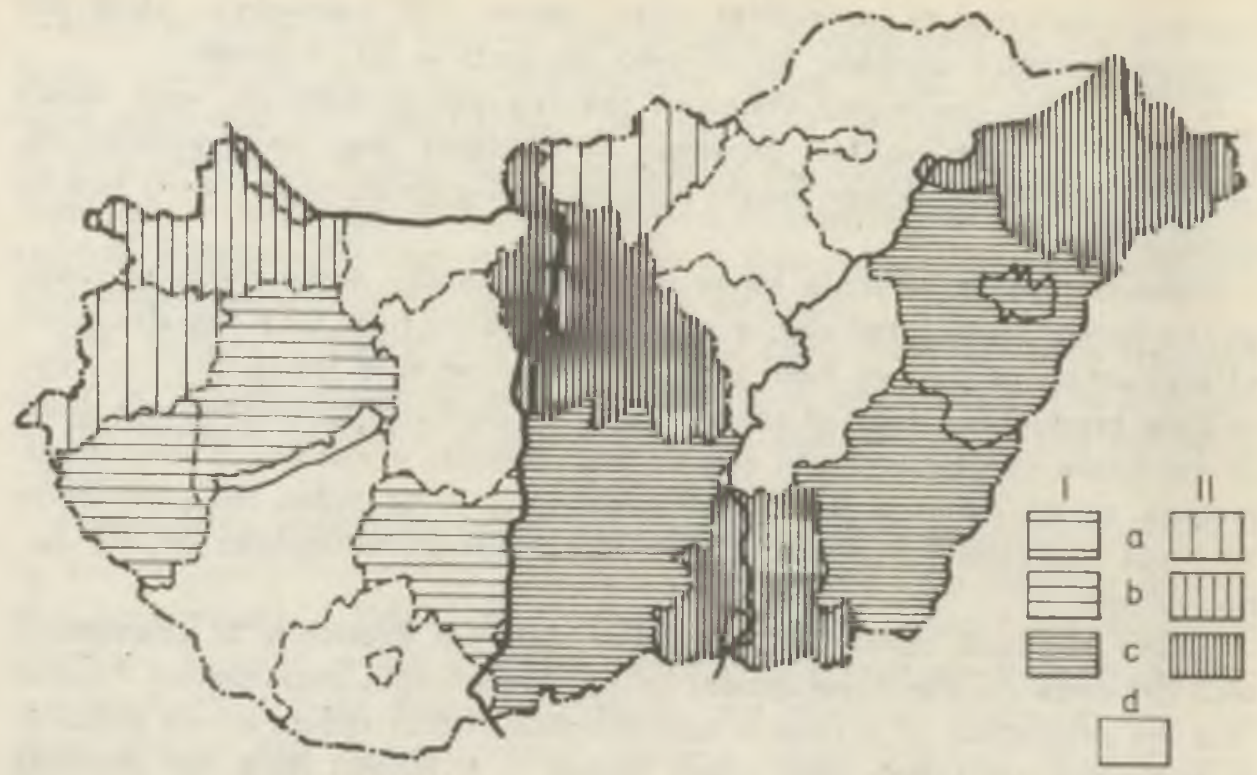

Fig. 2. Lnanges in the shares of the counties in the UVH of crop production (Arable Land + Meadow - Pasture) (1935/39-1962/66). - Legends see Fig. 1.

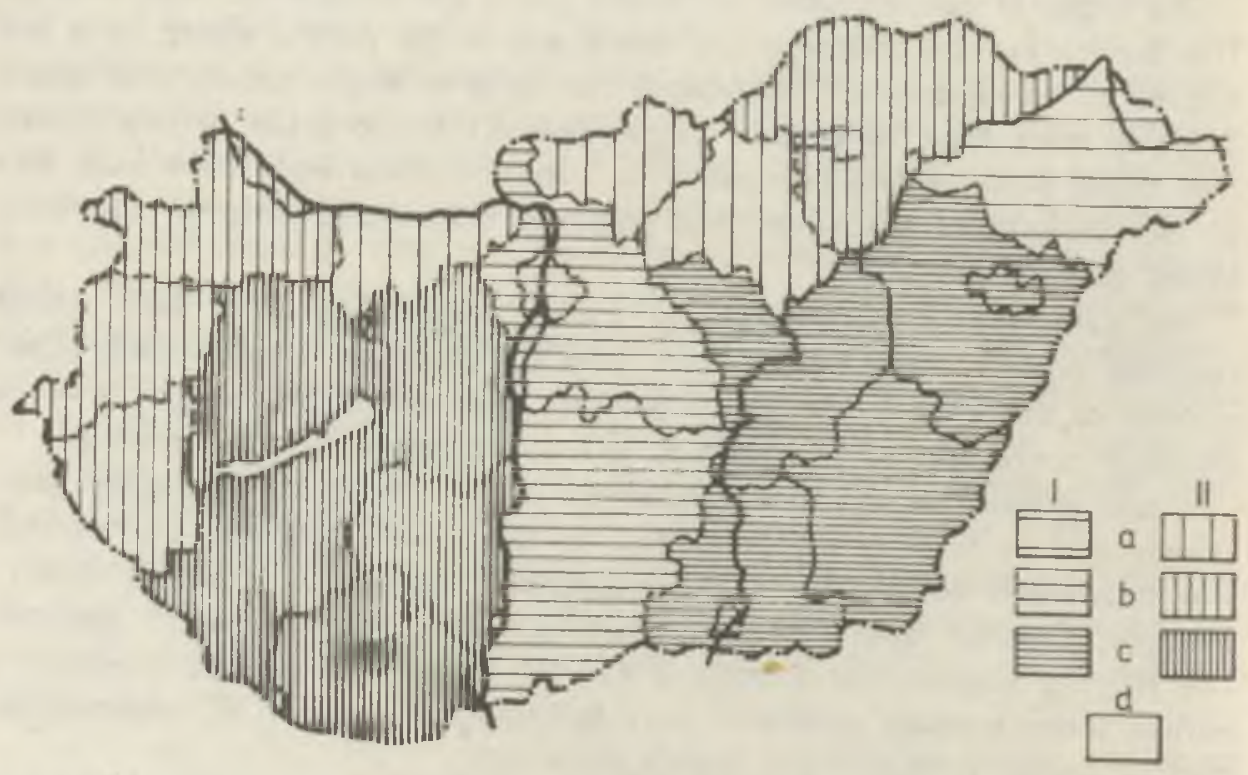

Fig. 3. Changes in the shares of the counties in the GPV of stock-breeding (Without Poultry) (1938-1962/66). Legends see Fig. 1. 


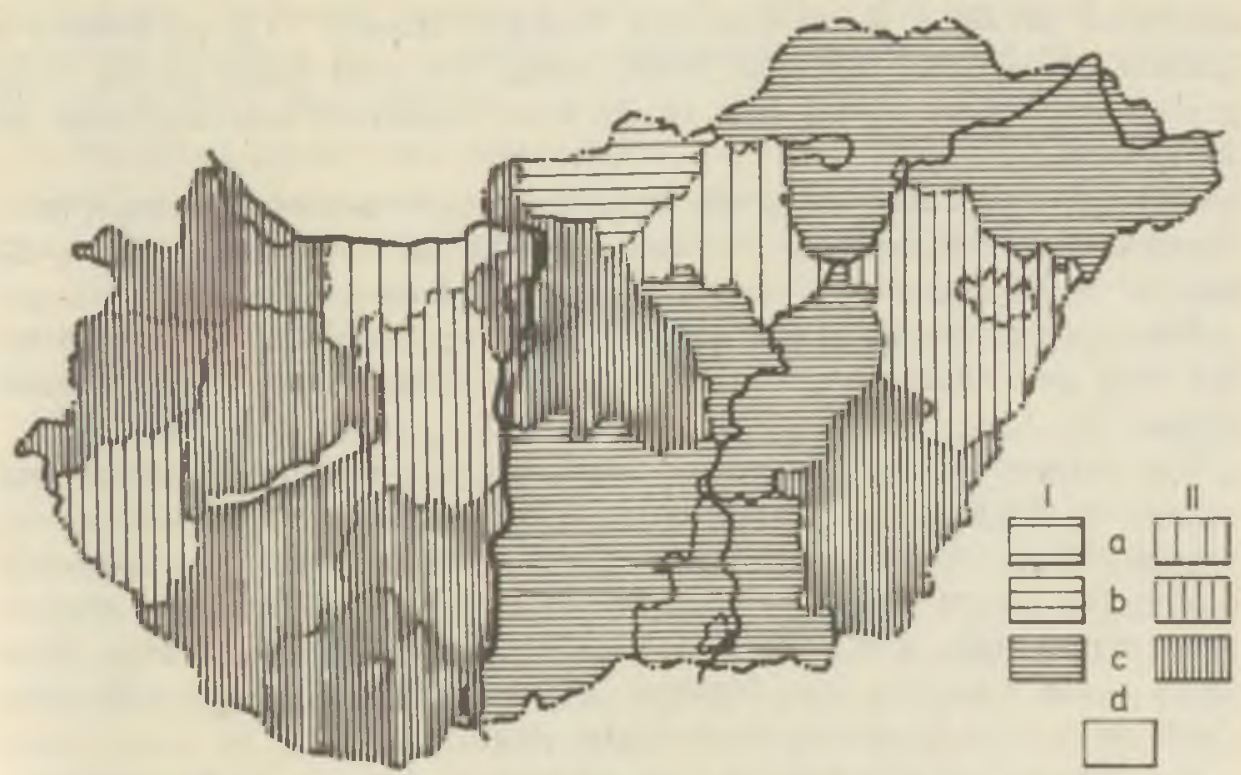

Fig. 4. Changes in the shares of the counties in the GPV of fruits (1935-1963/66.) Legends see Fig. 1.

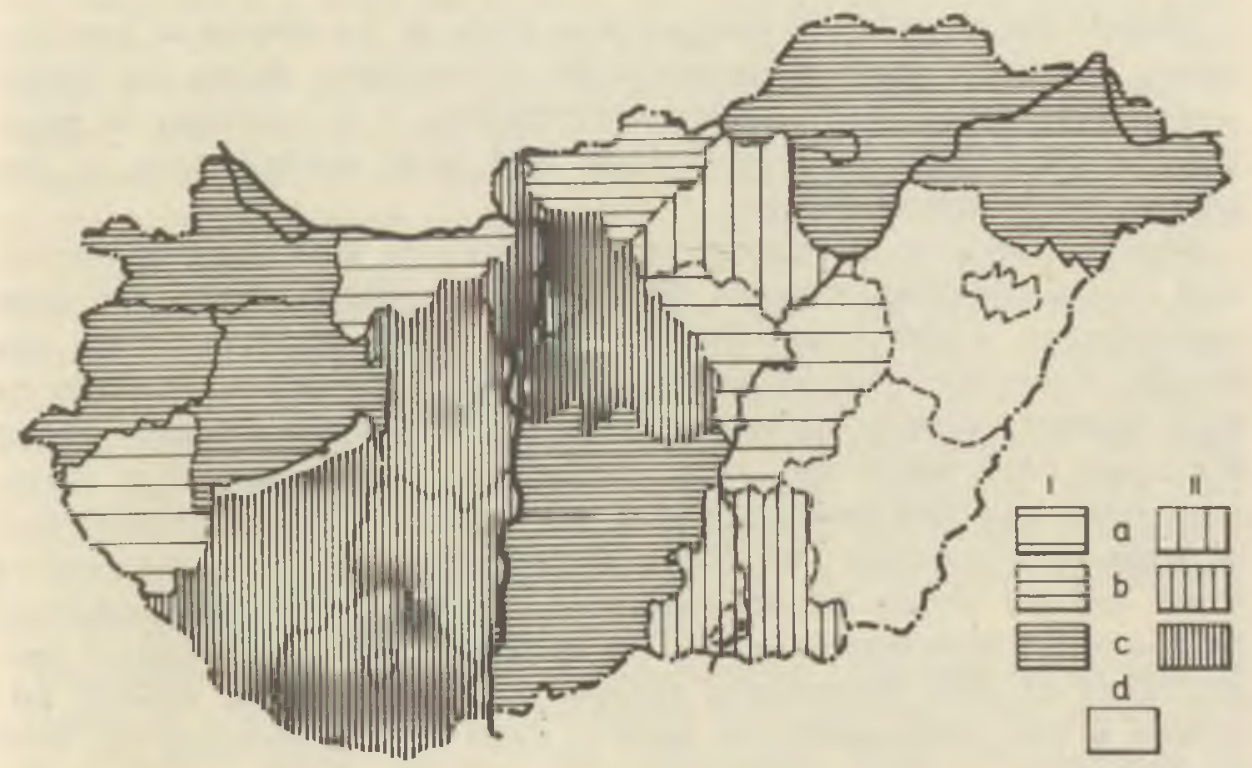

Fig. 5. Changes in the shares of the counties in the GPV of grape + wine (1935-1963/66). - Legends see Fig. 1. 
centrated. While in the thirties only Szaboles-Szatmár County yielded a quarter of the total industrial crops, today the total value of the main production regions (Békès and Hajdu-Bihar Counties) scarcely make up 25 percent.

Vegetable production is quite concentrated. At present the main production regions (Csongrád, Pest and Bács-Kiskun counties) yield only 52 percent of the total compared to the 59 percent they produced 30 years ago.

The regional concentration of stock-breeding remained unchanged for the most part. Only pork production is more concentrated than previously (Figure 3).

The concentration of production intensified only in fruit production and viticulture (Figures 4, 5). The regional concentration of viticulture was always higher than that of other crops, and it increased additionally during the period under investigation. The main wine-producing regions yield almost half of the total production. The district of Kisköros alone yields about 7 percent, and together with the three neighbouring districts, yields more than a quarter of the total production.

The regional development of fruit production shows a similar tendency. While earlier fruits were less concentrated, now the production is quite concentrated. The largest fruit production regions (Szabolcs-Szatmár, Pest, Bács-Kiskun and Borsod-Abaúj-Zemplén counties) yield about one-half of the total production.

Accordingly, no essential changes took place in the degree of specialization, nor in the regional concentration of production during the period under investigation. For a better understanding it is necessary to point out the correlations between regional and farm specializations in the present agriculture of Hungary.

After the socialist transformation of agriculture both agro-economists and agro-geographers assumed that a more vigorous regional and farm specialization would occur. One reason why this specializaton did not develop is that the financial and technical means of the large-scale farms were devoted mainly to the establishment of regional specialization among the single fields within their areas. Until now the development of largescale farms produced specialized units with large fields. By the organization of large-scale structure and financial strengthening of the co-operative forms we can expect the rationalization of the structure of production for the whole farm-enterprise and the realization of a more distinct specialization as well. Accordingly, regional specialization has already advanced in the micro-spaces, in parts of fields without attaining the farm level at all.

At present only a small part of the co-operatives can fulfil the technical requirements of specialized production. Besides the deficiency in the tech- 
nical basis, the former economic policy as well as the needs of the cooperative members for diversified employment counteracted the intensification of farm specializaton.

4. Hungary's current farm specialization can be characterized as follows:

Fifty percent of the co-operative farms and more that 40 percent of the state farms produce 16 to 20 kinds of crops. More than 20 kinds of crops are produced by one-third of the state farms and co-operatives. Wheat, maize, potatoes and lucern are produced in almost all farms. In addition, the bulk of the co-operatives has an orchard or a vineyard.

Cattle and hog-breeding is found on almost every farm, however, sheep are only raised on 80 percent of the state farms and 65 percent of the co-operatives. Nearly half of the state farms and 40 percent of the cooperatives deal with poultry breeding. Concerning the number: of products and the structure of production there is only a slight difference between state and co-operative farms. Although specialization developed in the cooperatives on more than three times as large an area as in the state farms. some of the state farms specialized more forcefully, though they are in minority for the moment. Ten percent of the state farms now produce less than 10 kinds of crops. Some state farms with plantation cultures show much stronger specialization.

Summing up, it can be stated that Hungarian agriculture specialization has advanced in a quick pace within the micro-spaces of the farms (fields, farm units, etc.). As a consequence of the faults of the former economic policy, and other problems such as employment needs and shortage of capital, farm specialization did not make a significant progress when compared to small-scale farming. This situation undoubtedly put a check on the economic growth of agriculture. It is obvious that the production of a great number of crops and the diversified stock-breeding hinder the development of a production structure that would the most suitably conform to the existing conditions. Among 20 to 25 crops there always occurs one or two that would yield very little profit, or even a deficit. In addition. the production of a great number of crops and animal products increases needs and dissipates efficient use of machines, buildings, etc. It also requires a considerable manpower and hampers the vertical integration of agriculture and food industry, because due to dissipation of supplies. the plants produce relatively small quantities.

Regardless of the importance of specialization, until now no conception capable of inducing a radical change in this field has been found. The new economic policy, however, has contributed to the enhancement of agricultural specialization by providing incentives for both state and cooperative farms alike. 


\section{BIBLIOGRAPHY}

Asztalos, I. (1968). Az állattenyẻsztẻs terûleti megoszlása Magyarországon (Territorial distribution of stock-breeding in Hungary). - Budapest: Akadémiai Kiadó, p 250.

Bernát, T. and Enyedi, Gy. (1961). A magyar mezōgazdasảg termelési kōrzetei. I. A szántōföldi növènytermelès körzelei. (Production regions of Hungarian agriculture. I. Regions of field production of crops). - Budapest: Mezōgazdasági Kiadó, p 168.

Bernát, T. and Enyedi, Gy. (1968). A mezōgazdaság területi lejlödèsẻnek fó jellemzōi, 1935/39-1962/66 (Chief characteristics of the regionol development of agriculture in Hungary, 1935/39-1962/66). - Budapest: MTA FKI, p 54. (MTA Foldrajtudományi Kutotó Intézet. Intézeti Munkajelentések 3.)

Enyedi, Gy. (1965). A mezōgazdaság földrajzi tipusai Magyarországon (Geographical types of agriculture in Hungary). - Budapest: Akadémiai Kiadó, p 71. (Földrajzi tanulmányok 4.)

Fazekas, B. (1967). Mexōgazdaságunk a felszabadulás utản (Hungarian agriculture after 1945). - Budapest: Mezōgazdasági Kiadó, p 391.

Géczy, G. (1968). Magyarország mezógazdasági területe (The agricultural area of Hungary). - Budapest: Akadémiai Kiadó, p 307.

Kováes, Cs. (1968). A règi es az új irónyítási rendszer lènyeges elemei a területi fejlesztes szempontjából és hatásuk a gazdaság terúleti orientációjában (Essential features of the old and new management systems for regional development, and their prevalenc: in the regional orientation of economy). - Kèzirat, Soksz. (Manuscript. Mineographed). Budapest, $p 87$.

Területi Statisztikai Zsebkōnyv 1967 (Regional Statistical Pocket-Book 1967). - Budapest: Statisztikai Kiadó (1968) p 523. 


\section{REGIONAL PROBLEMS OF STOCK-BREEDING IN HUNGARY}

\section{ASZTALOS}

Rapid industrialization of the country is closely connected with the development of agriculture. On the one hand agriculture provides a conspicuous contribution to the creation of the material foundations for industrialization, while on the other hand the development of industry contributes to the modernization of agricultural production. The close interaction notwithstading, the rate of development naturally differs considerably, since the development of agriculture in Hungary lags far behind that of the industry; however, in recent years the application of up-to-date agricultural lechnology - mechanization, utilization of chemicals, irrigation, etc. resulted in a more vigorous upswing in agriculture. Industry's contribution to the gross natural income increased 400 percent between 1950 and 1969. while agricultural production remained unchanged.

The structure of agricultural production changed little during the past two decades. Stock-breeding contributes 40 to 43 percent of the gross production value of agriculture. The low gross value of stock-breeding becomes even more obvious when it is taken into account that more than half (54.7 percent in 1963) of the arable lands were used for stock-breeding. Though the relative importance of the gross value of stock-breeding rose faster during the 1960s than that of plant growing, still plant growing had a stronger impact on the trend in the level of agricultural production. In 1968 the production value per one hectare of agricultural area amounted to 5998 Forints in plant growing, while the value of stock-breeding only amounted to 4520 Forints. There is, however, strongly negative feature in the development of agriculture in that the net production value did not increase simultaneously with the growth of gross production: on the contrary a set-back can be observed. Between the years 1963 and 1968 the ratio in the gross production value declined from 46.2 percent to 40.1 percent. This decline was due to the fact that because of the rapidly growing inputs of industrial origin material costs are increasing at a faster rate than the total production. While production is being modernized the investments directly affecting the growth of yieldes are falling behind. This process is associated with the large-scale development of agriculture and its effects are particulary evident in stock-breeding which is substantially more demanding in fixed assets, than plant growing.

In the structure of agriculture the importance of stock-breeding has grown in comparison to plant growing. Further development, however, can 
only result from internal changes within stock-breeding, especially emphasizing the importance of meat production.

The general European trend toward meat production evolved in Hungary as well, but its intensity did not keep pace with the European development in all respects. The meat production per animal approaches the general European level of production.

The evolution of our cattle breeding is favourable, as its beef production capacity, compared with the thirties, rose 195 percent and now approaches $80 \mathrm{~kg}$. per animal of the total stock. This quantity represents a good medium production level by European standards. In turn it is a disadvantageous phenomenon that pork productivity of our principal meat source - has grown only moderately, with a 20 to 25 percent increase and has attained a value of only $50 \mathrm{~kg}$. per animal of the total stock.

Our total meat production increased two and one-half times between 19.58 and 1968; but milk production only increased 25 percent. (I. Asztalos, 1969). The exports similarly are influenced by this peculiar trend in production. As a result of the different rate of development of plant growing and stock-breeding, and the change in the structure of domestic consumption, the export structure of our food economy, also has been modified. The proportion of export products of animal origin has risen gradually. Particulary the exports of slaughter cattle, beef, poultry, gooseliver, and eggs has increased more than the average. On the other hand, exports of pork and butter have declined. In 1969 food exports amounted to some 5.6 million exchange rate Forints, approximately half of which were provided, by stock-breeding. Stock-breading therefore has an extremely significant role, from both the export and domestic points of view.

Fattened cattle is the product which procures the most hard currency, amounting to about one-third of our exports to Western countries, while pork is an indispensable product for the domestic market since pork accounts for more than half of the domestic meat consumption. The development of stock-breeding, however, has not kept abreast of the increasing demand because several circumstances inhibit further progress.

When discussing the situation of stock-breeding, the livestock breeding of houshold plots of collective forms must be considered since they contribute significantly to the total production. While in plant growing up-todate, large-scalc farming could be realized at a relatively quick rate, stock-breeding essentially is a slower process precisely because of the heavy investment requirements. It is characteristic that as late as 19681.2 percent of all the cattle, 36.2 percent of cows and 35.8 percent of pigs could still be found in household plots. 
Nothing proves the importance of houshold plots better than the fact that their gross production value is 15 to 17 billion Forints which is 23 to 25 percent of the total gross value of agriculture. In household plots the products of stock-breeding bring in about 10 billion Forints or roughly 60 percent of the total production, and supply 14 to 15 percent of the total gross agriculture value. In past years, however, a modification occured in production structure of household plots, and their stock-breeding has declined. Not only did the relationship between plant growing and stockbreeding change by this modification, but the internal structure of stockbreeding changed as well. In 1961 pork occupied the first place in gross value, followed by the cattle and then by poultry. Since 1964, however, pork, poultry, and then cattle is the order of sequence.

The structural modification derives from the diversity of development. The 20 percent decline in cattle breeding since 1961 is sufficiently unambigous.

A decrease also can be anticipated in hog breeding, though in recent years an upswing can be noticed here. Only poultry raising is developing uniformly.

The large establishments show dynamic development; by means of heavy investments the number of stalls is growing rapidly, however, the number of stalls still is lagging far behind the requirements. On the other hand the limitations in the national economy make its impossible to replace all of the stalls in the household plots in the next few years. Only building the necessary cow stalls would cost in excess of ten billion Forints. In addition, it must be taken into consideration that a considerable proportion of existing buildings are unsuitable and do not satisfy up-to-date requirements. The pig stys in particular are very out-dated. Naturally, this situation leads to a low efficiency in feed conversion. "The pofitability of stock-breeding depends to a large extent upon the harmony of the breed, the fodder supply and management conditions". (J. Hont, 1969.)

The development of stock-breeding also is fundamentally influenced by the profitability which is very low in the field of stock-breeding. In the middle of the 1960s the prices of slaughter cattle were 30 percent more than production cost, while the price of milk was about 20 percent lower than the production cost. For fattened pigs, however, the price was 6 to 11 percent higher then cost. Slaughter poultry sold at prices 6 to 17 percent above cost, while for eggs 2 to 11 percent more was paid than the production cost. (J. Hont, 1969.) In the last ten years, and particulary after 1965, measures have been taken to increase the profitability of stockbreeding and the purchase prices have gone up. The purchase price of slaughter cattle rose 58 percent between 1958 and 1968 while milk rose 47 percent. These price increases, however, did not bring a fundamental 
change. In addition, a radical solution cannot even be expected from the price changes in 1968, though the total impact cannot be measured as yet.

An additional basic problem in the development of stock-breeding is the scanty fodder supply, the deficiency of feed, and particulary the substantial protein shortage. In the absence of up-to-date feeding methods the food conversion lags behind the level of most developed countries. This problem is especially evident in hog breeding where the small-scale management is the condigeneral rule and where the feed utilization is about 25 to 30 percent less efficient than in many Western European countries. Thus for the production of $1 \mathrm{~kg}$ of meat 4.6 to $4.8 \mathrm{~kg}$ of feed must be utilized.

In the development stock-breeding, the regional differences in the evolution of breeding are influenced by a large number of additional factors which include: the decrease in stock rearing on household plots, the gradual aging of the rural population, the change in the circumstances of rural life following industrialization, the periodic marketing difficulties, etc. The future development and modernization of the stock-breeding industry can be expected to be slower then progress in plant growing because the products of the household animal keeping will continue to remain indispensable for a long time to come both for domestic consumption and for foreign trade. The prevalance of small-scale livestock breeding will mean in turn, that though the commodity bases will grow, productivity and profitability will rise only slowly.

\section{Changes in the regional structure of the fodder supply}

An important inhibiting factor in the development of stock-breeding at a more rapid rate is the need for up-to-date feeding though some progress can be observed in this area. The improvement of fodder bases is evident in the structure of production, and in the increases in the quantity and the quality of the produce.

In the formation of fodder supply the field growing of fodder is of primary importance $(67.7$ percent). The 32.3 percent ratio of the meadow and pasture areas, however, demonstrates that with a modern gross-land management these areas form a very large reserve for stock-breeding. The development of fodder growing is not uniform, and therefore provides no basis for a considerable increase in the livestock. For example, Table 1 indicates that the growing area decreased more than 10 percent between 1960 and 1969, but as indicated by Table 2, the total number of large animals is only 7.5 percent less. It is obvious then that the fodder supply of the livestock apparently has deteriorated. 
Table 1.

CHANGES IN THE FODDER GROWING AREA

\begin{tabular}{lccccc} 
& \multicolumn{3}{c}{1960} & & 1969 \\
& 1000 hectar & $\%$ & 1000 hectar & $\%$ & $1960=100$ \\
& & & & & \\
Field fodder growing area & 3027 & 67,8 & 2704 & 67,7 & 89.3 \\
Meadow pasture & 1437 & 32,2 & 1290 & 32,3 & 89,7 \\
Toral fodder growing area & 4484 & 100 & 3984 & 100 & 89,4
\end{tabular}

Table 2.

TREND IN LIVESTOCK PRODUCTION

\begin{tabular}{|c|c|c|c|c|}
\hline \multirow{2}{*}{ Animal } & \multicolumn{2}{|c|}{1000 heads } & \multicolumn{2}{|c|}{$1960=100$} \\
\hline & 1935 & 1960 & 1969 & 1969 \\
\hline Cattle & 1918 & 1971 & 2006 & 101.8 \\
\hline Pigs & 4674 & 5356 & 5334 & 99,6 \\
\hline Horses & 886 & 628 & 249 & 39,6 \\
\hline Sheeps & 1460 & 2381 & 3277 & 137,6 \\
\hline futal large animals ${ }^{a}$ & 1280 & 2858 & 2645 & 925 \\
\hline
\end{tabular}

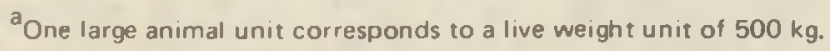

In actual fact fodder growing has decreased, occupying a smaller proportion (54.7 percent) of arable lands than it did in 1960 (57 percent), but its composition is better adapted to the structure of livestock, because parallel to the growth of the cattle stock the cultivation of roughes within the field growing of fodder plants has grown (its ratio being 37.2 percent in 1968 compared to 34.2 percent in 1960). Between 1960 and 1969 there was a large, 14 percent decrease in crop lands in the growing of grain fodder plants. Barley production has declined about 24 percent, and the lands devoted to maize production decreased by about 10 percent. In contrast to this trend there is a six percent increase in the roughages growing area, and with this change there has been an increase in the production of lucerne which from the point of view of protein supply of stock-breeding is very significant. Although the total acreage of clover has declined, in 1968 the acreages of two most important papilionaceous plants, lucerne and clover in 1968 still exceeded that of 1960 by 3 percent.

Although the crop land of fodder plants decreased, the quantity of produced nutritive value has grown due to the modification in the structure of fodder growing and to the increase in per acre yields. Consequently the possibilities for feeding have improved. In 1968 the production of 
concentrates was about 4 percent higher, than in 1960. Although the protein ratio worsened somewhat, it was compensated for by an increase in the imports of protein-feeds and in the utilization of the industrial proteins. According to calculations of the Central Planning Office, 16.6 percent of the total feed-utilization in 19651966 . was covered by imported protein feeds. (J. Hont, 1969.)

The increases in yields were obvious not only in the improvement of concentrate supply, but also in the formation of roughage stocks. As a result with only a 3 percent increase in the growth of areas of papilionaceous plants, the increase of the crop quantity amounted to 10 percent. Another optimistic phenomenon is that the shrinking of meadows and pastures did not mean a decrease in the fodder quantity obtainable from them because there was a corresponding rise in yields.

The changes in fodder production were not uniform throughout the country. There was considerable divergence between the various regions, and these divergencies affected the structure of stock-breeding. The major region for production of maize which traditionally has been grown in the Great Plain has gradually moved to Transdanubia. The development and availability of short vegetation period hybrid seeds, and the profitability of hog breeding undoubtedly have contributed to this change. Between 1960 and 1968 the percentage of maize grown in Transdanubia rose from 35.3 percent to 39.9 percent, while that of the Great Plain declined from 54.7 to 51.2 and the production of the North fell from 10 to 8.9 percent. The growing of barley has declined in general, particularly in Transdanubia, and to a lesser extent in the Great Plain, while in the North a stagnation is more characteristic. As a result of the diversity in the area of declining cultivation, the porportion of barley growing has increased on the Great Plain and in the North. It is characteristic that in the production of lucerne and clover, lucerne growing has widened, and the crop land of clover has decreased in general and its importance in the cultivation of papilionaceous plants declined, mainly in Transdanubia. The fodder basis of roughages deteriorated in Transdanubia because the growing of silage maize became more widespread. The proportion of meadows is high but they supply a qualitatively poorer feed. In contrast to this situation, the fodder base of roughages has improved in the Great Plain. Fodder growing in the North declined generally, however, it is optimistic that the protein production is favourable as indicated by the high porportion of barley and red clover (Table 3 ).

Of course the diminution of the fodder growing area does not necessarely mean a corresponding decrease in the produced stocks, but a decrease can be observed. The 1968 stocks of concentrate feed in Transdanubia and on the Great Plain exceed those of 1960 by about 6 to 7 
Table 3.

DISTRIBUTION OF THE FODDER SUPPLY 1968

\begin{tabular}{|c|c|c|c|c|c|c|c|c|}
\hline \multirow{2}{*}{ Feed } & \multicolumn{2}{|c|}{ Transdanubia } & \multicolumn{2}{|c|}{ Great Plain } & \multicolumn{2}{|c|}{ Northern Hung. } & \multicolumn{2}{|c|}{ Hungary } \\
\hline & ha & $\%$ & ha & $\%$ & ha & $\%$ & ha & $\%$ \\
\hline Barley & 124,7 & 32,3 & 174,2 & 45,2 & 86,5 & 22,5 & 385,4 & 100 \\
\hline Maize & 505,2 & 39.9 & 644,1 & 51,2 & 110,4 & 8,9 & 1259,7 & 100 \\
\hline Lucerne & 106.1 & 30,9 & 196,8 & 57,4 & 39,8 & 11,7 & 342,7 & 100 \\
\hline Clover & 56,8 & 41,7 & 43,8 & 32,2 & 35,5 & 26,1 & 136,1 & 100 \\
\hline Silage maize & 85,8 & 44,9 & 89,6 & 46,9 & 15,5 & 8,2 & 190,9 & 100 \\
\hline Meadows & 213,5 & 51,9 & 138,6 & 33,6 & 59,2 & 14,5 & 411,3 & 100 \\
\hline Pasture & 271.0 & 30,9 & 457,5 & 52,1 & 148,8 & 17,0 & 877.4 & 100 \\
\hline
\end{tabular}

Crop quantities in 1000 tons

$\begin{array}{lrrrrrrrr}\text { Barley } & 311,2 & 34,4 & 411,7 & 45,6 & 180,9 & 20,0 & 903,7 & 100 \\ \text { Maize } & 1616,4 & 42,9 & 1890,6 & 50,2 & 256,9 & 6,9 & 3764,0 & 100 \\ \text { Lucerne } & 329,0 & 28,6 & 712,7 & 61,9 & 110,4 & 9,5 & 1152,1 & 100 \\ \text { Clover } & 141,3 & 41,6 & 124,7 & 36,7 & 73,4 & 21,7 & 339,4 & 100 \\ \text { Silage maize } & 1685,5 & 52,5 & 1309,1 & 40,7 & 217,8 & 6,8 & 3215,5 & 100 \\ \text { Meadows } & 363,8 & 53,4 & 196,0 & 29,6 & 112,5 & 17,0 & 662,2 & 100 \\ \text { Pasture } & 313,7 & 31,5 & 517,3 & 50,9 & 177,7 & 17,6 & 1014,7 & 100\end{array}$

percent while in papilionaceous feeds the development is not so unambigous, since in Transdanubeia the crop quantities of lucerne and clover were nearly 20 percent less in 1968 than in 1960. On the Great Plain, however, a 48 percent larger quantity of these feeds was available. On the Great Plain the modernization of production techniques and significant improvements in irrigation facilities undoubtedly have contributed to the increases in roughages acreages. In Northern Hungary the feeding possibilities have generally deteriorated, because in 1969 the quantities of both concentrate and papilionaceous feeds decreased considerably.

The regional rearrangement of fodder growing and of the cultivation of various fodder plants produced a change in the regional distribution of livestock as well. In Transdanuba cattle and sheep breeding declined in importance while pig breeding flourished.

On the contrary in the Great Plain cattle and sheep breeding is in creasing. As shown in Table 4, the place occupied by the North in the stock-breeding of Hungary is on the decline in general.

A consequence of the regional rearrangement of stock-breeding as that of the traditional regional specialization is getting weaker and as a new tendency toward uniformity in the structure of stock-breeding is developing. This trend, naturally will not mean a complete uniformity in breeding, be- 
Table 4.

REGIONAL DISTRIBUTION OF THE LIVESTOCK

\begin{tabular}{|c|c|c|c|c|c|c|}
\hline \multirow{2}{*}{ Animal } & \multicolumn{2}{|c|}{ Transdanubıa } & \multicolumn{2}{|c|}{ Great Plain } & \multicolumn{2}{|c|}{ North Hungan } \\
\hline & 1960 & 1969 & 1960 & 1969 & 1960 & \\
\hline Cattle & 44,2 & 42,6 & 42,0 & 44.3 & 13,8 & \\
\hline Pigs & 34,6 & 37.5 & 55,6 & 53.1 & 9.8 & \\
\hline Horse & 34.0 & 33.2 & 53,8 & 56.0 & 12,2 & \\
\hline \multirow[t]{3}{*}{ Sheep } & 27,8 & 22.9 & 54,9 & 61,9 & 17,3 & \\
\hline & \multicolumn{6}{|c|}{ STRUCTURE OF LIVESTOCK IN 1969} \\
\hline & & Transdanubia & Great Plain & North Hungary & & Hungary \\
\hline Cattle & & 66,3 & 55,1 & 64,8 & & 60.7 \\
\hline Pigs & & 22,1 & 25,0 & 17.7 & & 22.9 \\
\hline Horse & & 6,4 & 8,7 & 6.7 & & 7.5 \\
\hline Sheep & & 5,2 & 11,2 & 10.8 & & 8,9 \\
\hline Total large an & imals & 100,0 & 100,0 & 100,0 & & 100,0 \\
\hline
\end{tabular}

cause as shown by Table 5, and Figure 1, in Transdanubia and in Northern Hungary cattle breeding continues to be predominant while the Great Plain is leader in hog breeding.

\section{Regional differences in stock-breeding}

In the stock-breeding industry, in general, meat production is of primary importance and now this trend is becoming more and more evident in cattle breeding as well. There has been rapid development in the production of beef as the gross yield per animal of stock rose from $61 \mathrm{~kg}$. in 1960 to $78 \mathrm{~kg}$. in 1968. The stock is still growing at a low and uneven rate while the dairy stock dieclines constantly. In 1969 the dairy stock consisted of 748,600 animals or not more than 37.3 percent of total stock. In the formation of this tendency a considerable role was played by the low profitability of dairy production. This situation is a detrimental phenomenon because it complicates the problem of replacement and also can involve the reduction of milk production. In addition it may jeopardize the consumption of milk and dairy products which already is low by European standards. Until 1967 the numerical reduction was compensated for by increases in milking yields $(2600 \mathrm{~kg}$ year cow in 1968). Since that time, however, a set-back can be noticed in the quantity of milk production. 


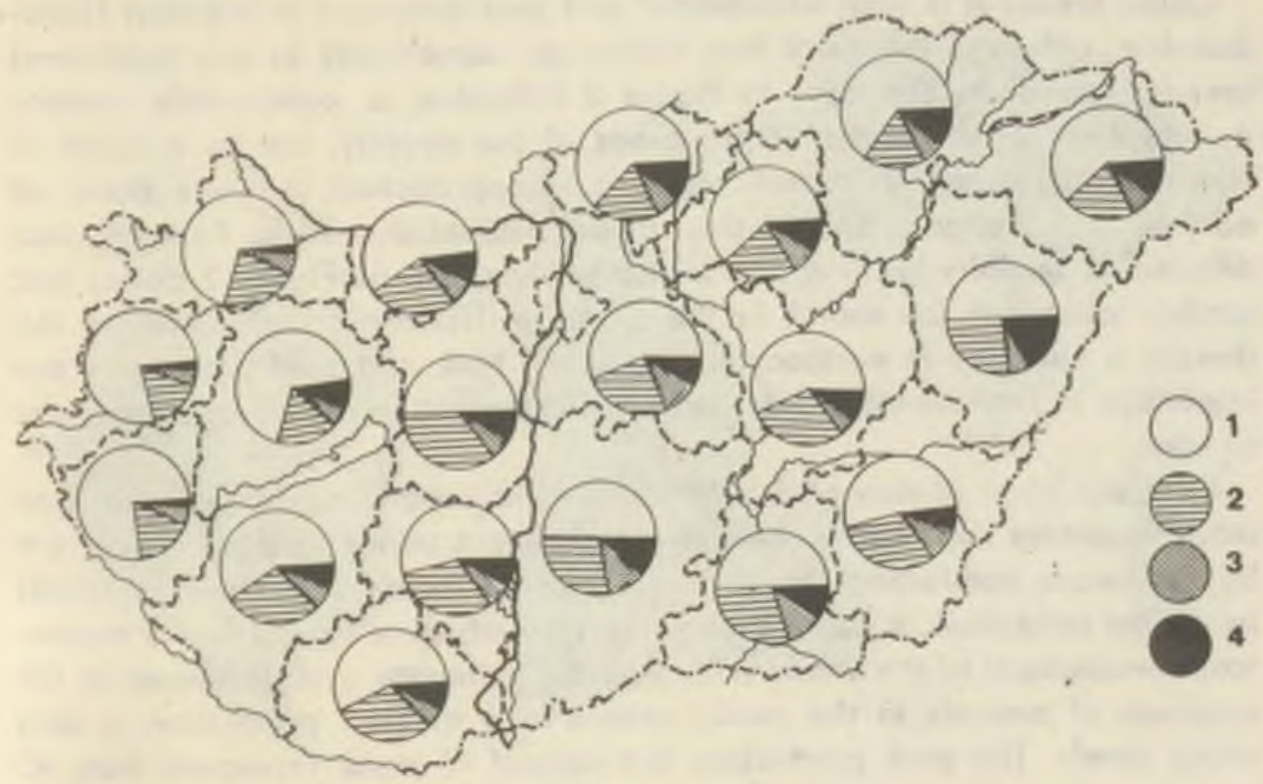

Fig. 1. Livestock population in 1969. $-1=$ cattle; $2=$ pigs; $3=$ horses; $4=$ sheep

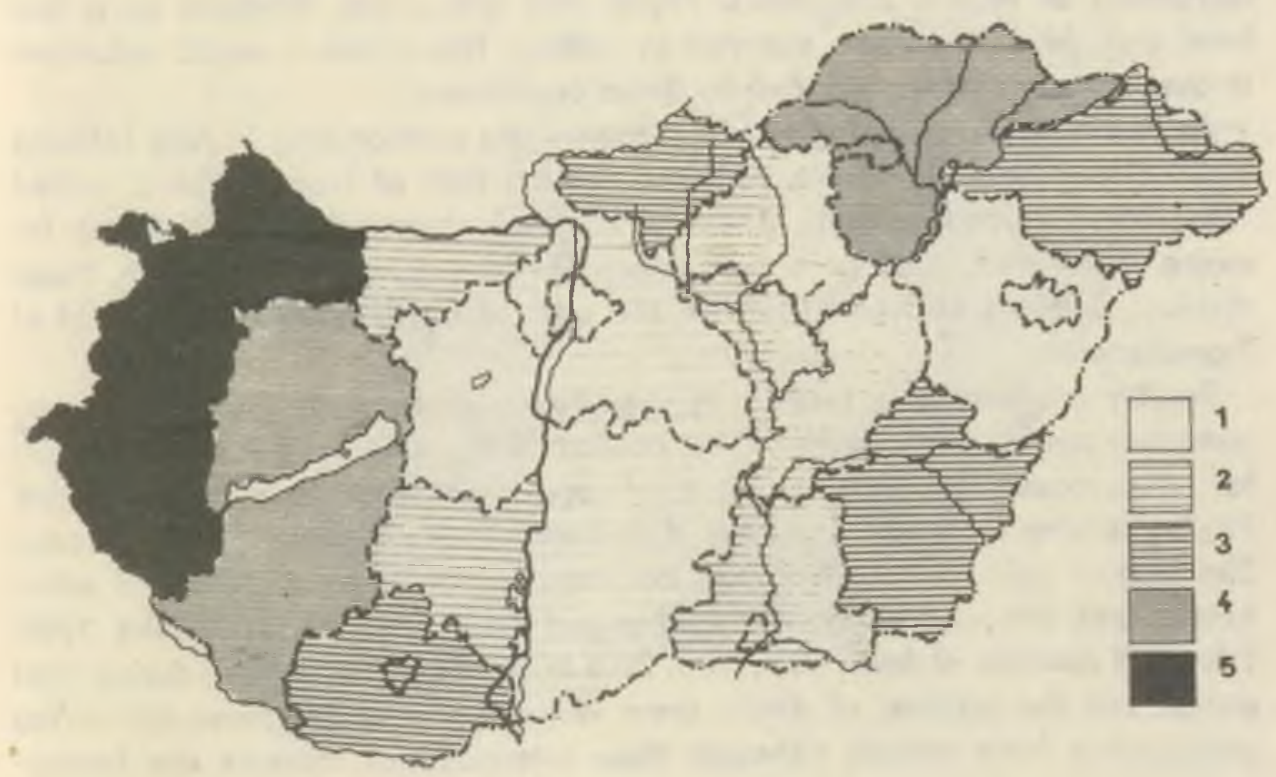

Fig. 2. Cattle per 100 ha agricultural area in 1969. - Numbers: $1=$ below $25 ; 2=25-28$; $3=28-31 ; 4=31-36 ; 5=$ above 36 
Cattle breeding is most widespread and best balanced in Western Transdanubia, although the stock has decreased numerically in this traditional breeding area. As the data in Figure 2 indicates, a comperable animal density cannot be found in other areas of the country, but as a result of the vigorous growth in recent years, it is approached in some parts of northeastern Hungary and of the region east of the Tisza. Few regional differences in dairy farming can be noted, because as Figure 3 points out, similar ratios can be found in the Danube-Tisza mid-region, where the density is low, and in northeastern Hungary. Milk and beef production are important in Transdanubia from both the quantitative and qualitative point of view.

From the point of view of the domestic meat supply hog breeding is even more important than cattle breeding, and recent trends in this industry are by no means comforting. Since hog breeding reacts sensitively to trends in market conditions, it has a cyclic character which is typical in the numerical development of the stock. With periodic increases and decreases in the numbers of animals in the stock, growth rate of pork production is only rising slowly. The pork production per animal of stock increased from 45 $\mathrm{kg}$. in 1960 to not more than $49 \mathrm{~kg}$. in 1968. The development is slow and not linear, in spite of the fact that it is more profitable than cattle breeding.

In the decline of hog breeding a considerable role was played by a decrease in the output of household plots which originally was caused by the worsening of market conditions. Piglet and gilt prices dropped to a low level and difficulties even occured in selling. There was a rapid reduction in the number of sows induced by these conditions.

As Figure 4 shows two areas of Hungary are outstanding in hog farming the region beyond the Tisza, and the eastern half of Transdanubia, called "Mezóföld" (Meadow-field). These areas are the traditional districts for maize cultivation, and pork production is correspondingly high in these districts, but it is also very lively on the eastern border and central third of Transdanubia.

Poultry production is second in importance after pork. Per capita consumption per year are: pork $27 \mathrm{~kg}$. poultry $12 \mathrm{~kg}$. and beef $9 \mathrm{~kg}$.* Precisely for this reason the development of poultry raising is very important. Poultry raising is rather uniformly distributed over all parts of the country. The largest part of the stock can be found in household plots and other farms, and the size of the stock changed little between 1960 and 1969. The total number of fowls rose from $\mathbf{2 5 . 5}$ million to 26.6 million during that period but the number of ducks grew very slightly while goose and turkey populations have shrunk although their international markets are favour-

- Pure meat only, without sausages, liver, etc; the total meat and meat product consumption is $60 \mathrm{~kg}$. per capita a year. 


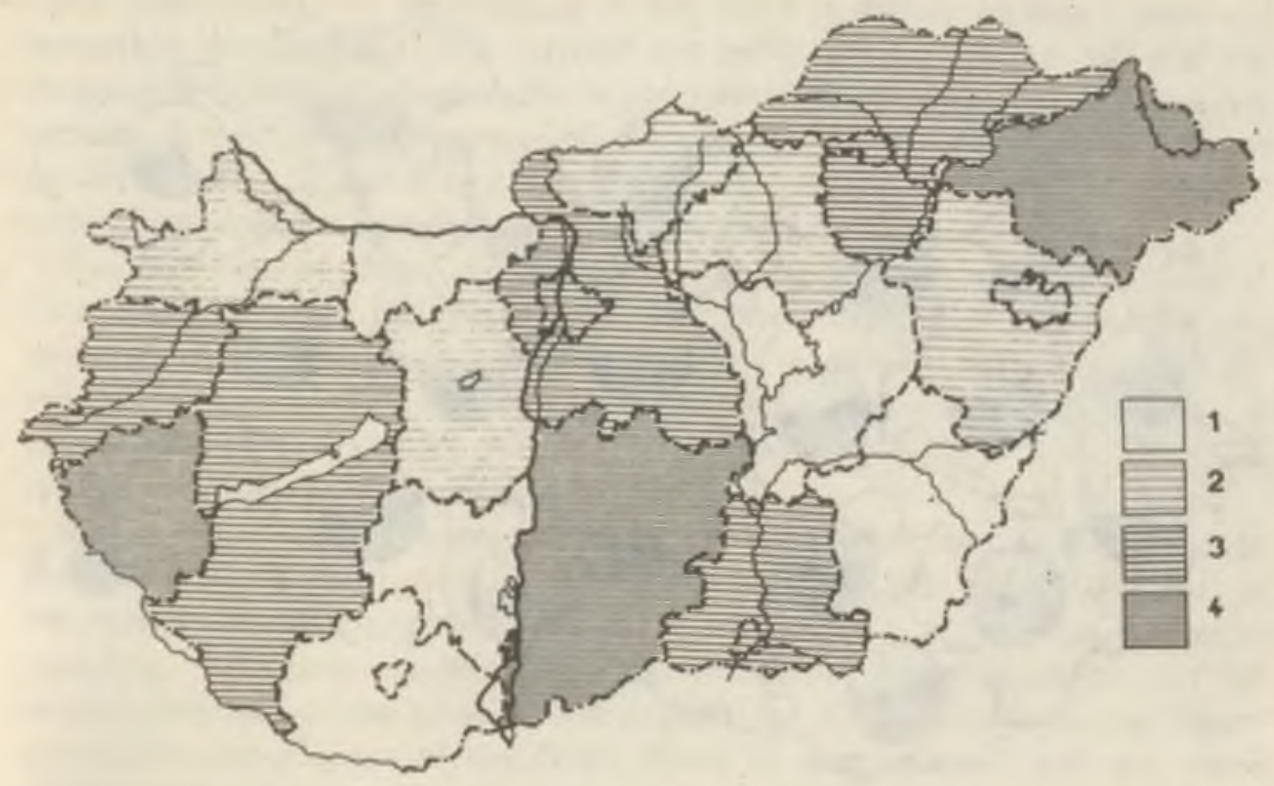

Fig. 3. Ratio of cows in the cattle stock in 1969. $-1=$ below $36 ; 2=36-37 ; 3=$ $37-38,5 ; 4=$ above 38,6

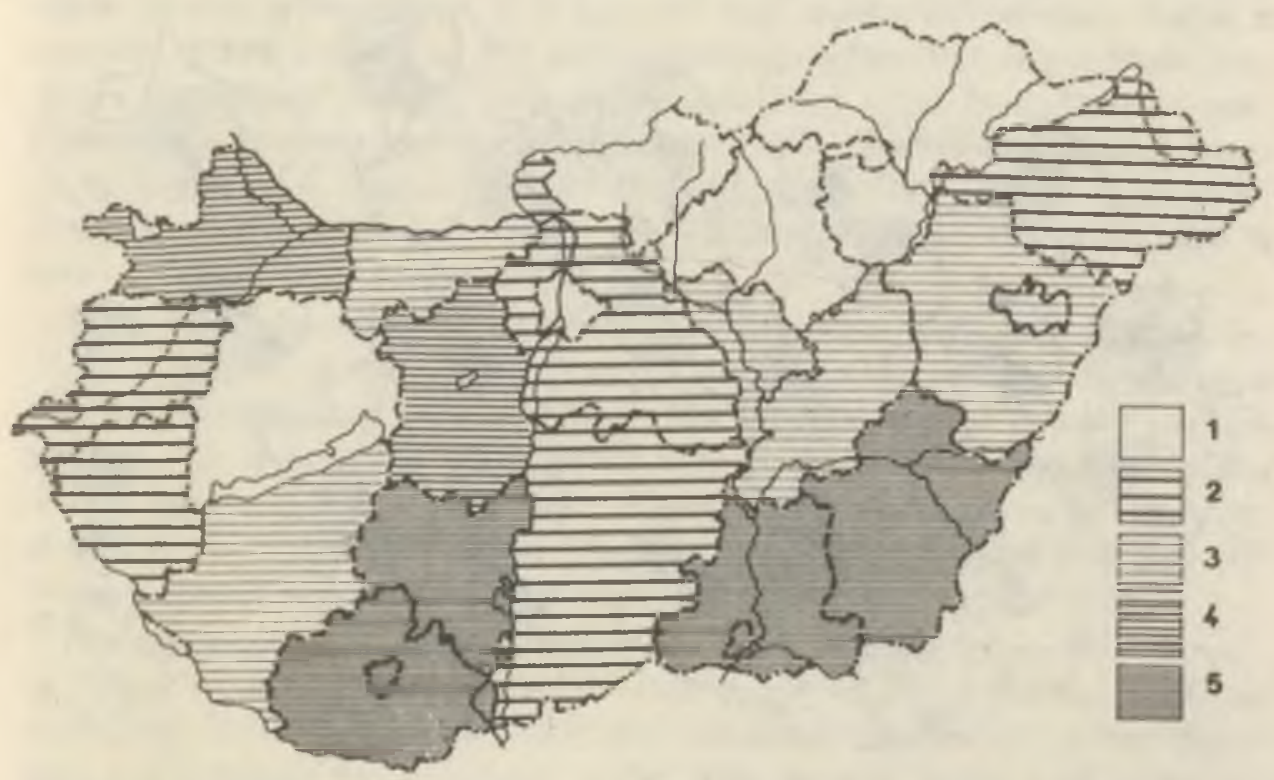

Fig. 4. Head of pigs per 100 ha agricultural area in 1969. - Numbers: $1=$ below 60 ; $2=60-80 ; 3=80-85 ; 4=85-90 ; 5=$ above 90 


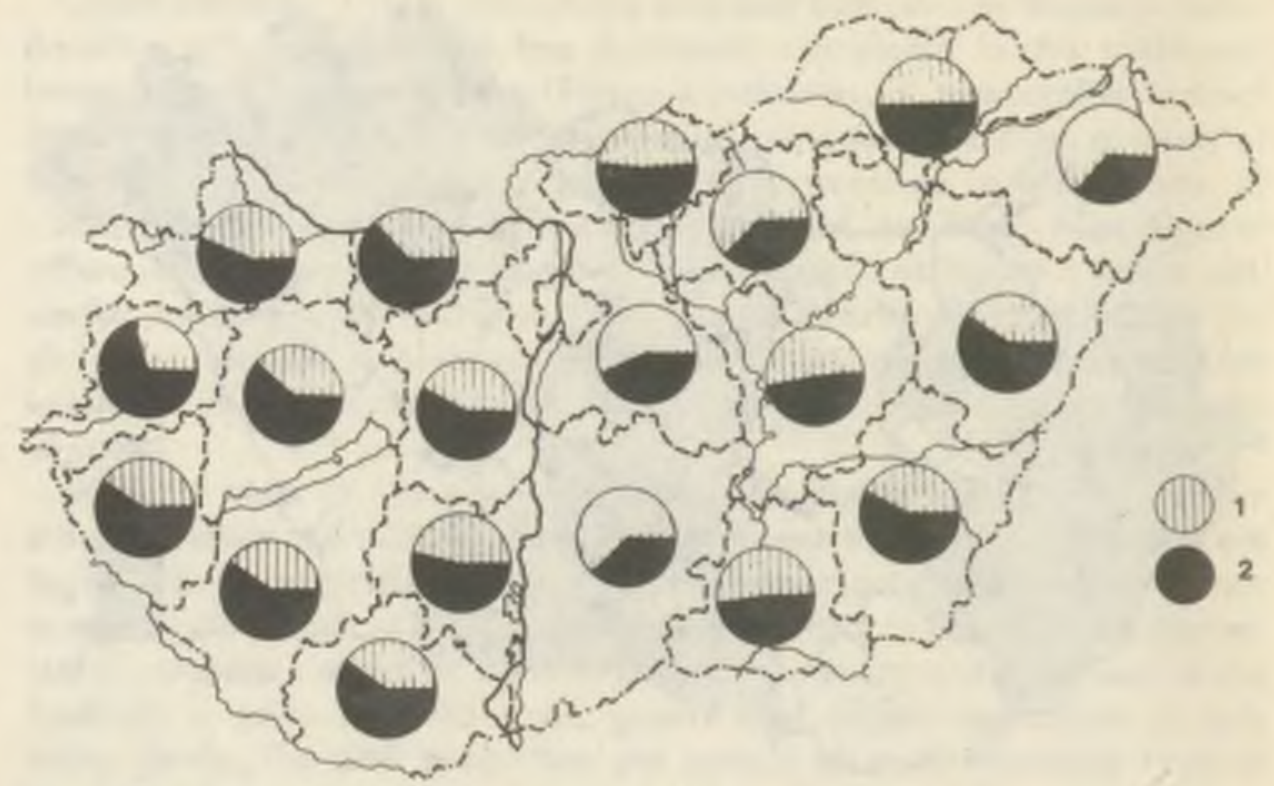

Fig. 5. Structure of the gross value of market production (State purchases.) in 1968. $1=$ plant products; 2 = slaughter animal and animal products

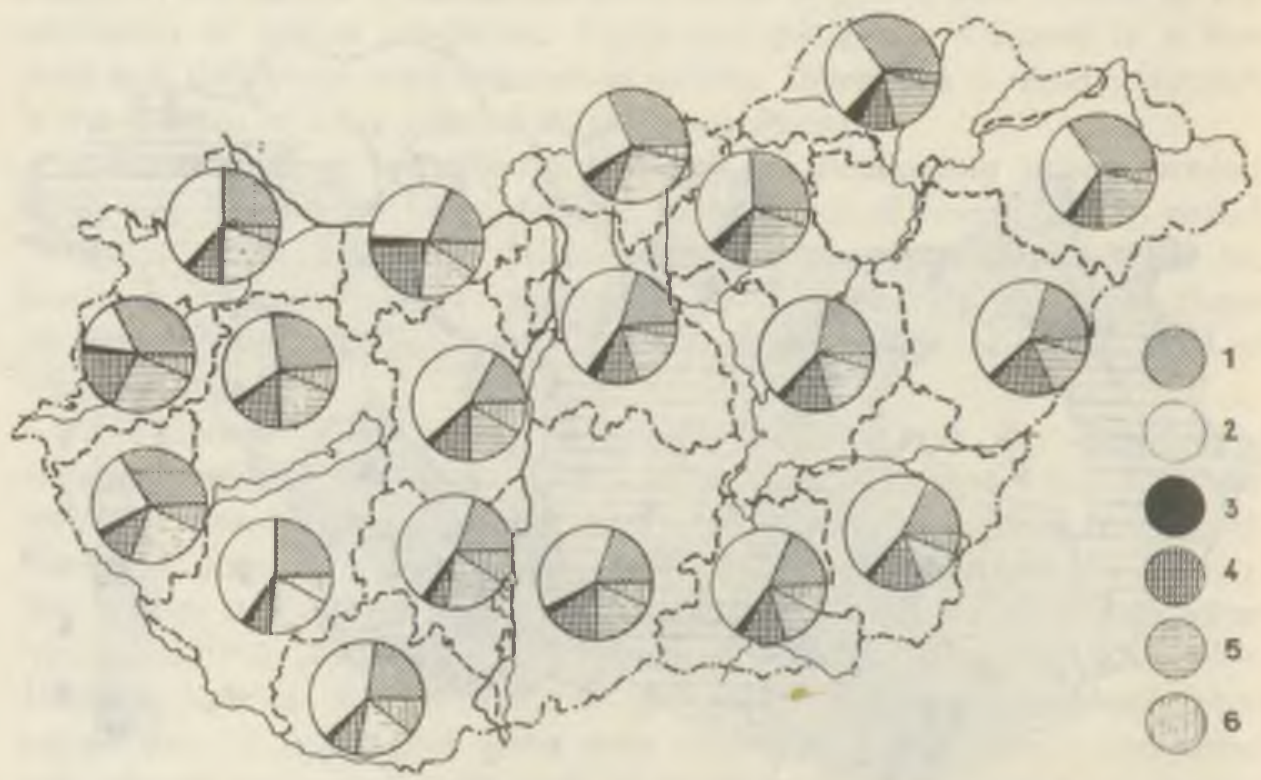

Fig. 6. Distribution of the gross value marketing of anımas products (State purchases) (1268). $-1=$ slaughter cattle: 2 = slaughter hogs; $3=$ slaughter sheep; $4=$ poultry: $5=$ milk; $6=$ eggs 
able. The increase in productivity of the stock is more significant than the numerical development. The average egg yield rose from 85 to 100 and the quantity of broiler production increased nearly 30 percent. The considerable growth of meat production was made possible by the development of the broiler industry. The broiler production is concentratid on the Great Plain; while Transdanubia excells in egg production.

The breeding of sheep and horses is of minor economic importance in Hungary. The Great Plain is the basic location of both of these industries because of the extensive pastures and the scattered farmsteads of the region. Sheep breeding in this area is showing a rather vigorous development, while as a result of the mechanization of agriculture horse breeding is gradually losing its basis for existence.

In Transdanubia the composition of livestock (the joint share of cattle and hogs in the total stock of large animals amounts to 88.4 percent) is the most favourable and the level of breeding also is highest there. Stockbreeding is the primary branch in agriculture of the area which has an outstanding role in the total market production. On the contrary, as Figure 5 indicates most areas of the Great Plain as well as the North are more significant for the gross production value of plant products.

The market production of stock-breeding has developed considerably. Pork occupies the first place and accounts for 48.1 percent of the total weight of all slaughter animals. Beef accounts for 37.5 percent of the total: while poultry amounts to 11.8 percent and sheep 2.8 percent. Table 6 presents a break-down of the production by region. The Great Plain produces the largest number of hogs for slaughter, while Transdanubia contributes the largest quantity of slaughter cattle. Transdanubia also leads in milk and egg production. On the Great Plain poultry and slaughter sheep production is outstanding. The slaughter sheep production also is very considerable in northern Hungary.

There is a considerable divergence between the production of the individual regions of the country. Though the Great Plain and Transdanubia lead in production of slaughter hogs, the slaughter cattle industry is close behind it in importance in Transdanubia, while in the Great Plain cattle raising lags and thus pork production and poultry acquires a greater importance. In northern Hungary the production of slaughter cattle is the primary branch but the slaughter hog industry is not insignificant there.

The significance of the production of stock-breeding, however, is reflected more readily in its gross-value. Figure 6 , which lists the value of the production for various areas, shows that slaughter hogs are in the first place, and are followed by slaughter cattle, milk, poultry, eggs and finally by slaughter sheep. The structure of the stock-breeding in Transdanubia and on the Great Plain generally corresponds to this sequence but naturally 
REGIONAL DISTRIBUTION OF THE MARKETING ANIMAL PRODUCTS

\begin{tabular}{|c|c|c|c|c|c|}
\hline Den & aination & Transdanubia & Great Plain & North & Hungary \\
\hline Slaughter cattle & tons & 140098 & 130994 & 33613 & 305515 \\
\hline Slaughter hogs & tons & 162557 & 206619 & 24992 & 394168 \\
\hline Slaughter sheep & tons & 6547 & 12507 & 4078 & 23132 \\
\hline Poultry & tons & 38024 & 52913 & 5403 & 96340 \\
\hline Milk mill. liters & & 550,1 & 472.3 & 111,0 & 1133,4 \\
\hline Eggs, millions & & 446,9 & 342,8 & 39,9 & 829.6 \\
\hline & & $\%$ & & & \\
\hline Slaughter cattle & & 46.1 & 42.9 & 11,0 & 100 \\
\hline Slaughter pigs & & 41,2 & 52.4 & 6,4 & 100 \\
\hline Slaughter sheep & & 28,3 & 54,1 & 17,6 & 100 \\
\hline Poultry & & 39.5 & 54,9 & 5.6 & 100 \\
\hline Eggs & & 53.9 & 41,3 & 4.8 & 100 \\
\hline Milk & & 48.5 & 41,7 & 9.8 & 100 \\
\hline
\end{tabular}

Table 7. VALUE OF THE COMMODITY PRODUCTION OF STOCK-BREEDING

Product

Slaughter cattle

Slaughter hogs

Slaughter sheep

Poultry

Milk

Eggs

Toral

Slaughter cattle

Slaughter hogs

Slaughter sheep

Poultry

Milk

Eggs

Total

\author{
Transdanubia
}

1690,9

2487.1

36,7

798,5

1375,2

554,2

6942,6

24.4

35,8

0,5

11,5

19,8

8,0

100,0
Great Plaın North Hungary

Hungary

1571,9
3161,3
70,0
1111,2
1180,8
424.5
7519.7

403,4

382,4

$\therefore, 6$

113,5

$27 / 5$

49,5

1249,1

15711,4

$\%$

$\begin{array}{rrr}20,9 & 32,3 & 23,3 \\ 42,0 & 30,6 & 38,4 \\ 0,9 & 1,8 & 0,8 \\ 14,8 & 9,1 & 12,9 \\ 15,7 & 22,2 & 18,0 \\ 5,7 & 4,0 & 6,6 \\ 100,0 & & 100,0\end{array}$

3666,2

6030,8

129,5

2023,2

2833,5

1028,2

23,3

12,9

6,6

100,0 
there are different ratios corresponding to the particularities of market production in stock-breeding. In northern Hungary the composition is modified inasmuch as slaughter cattle occupies the first place in importance and similarly, the production of milk is very high.

Development of stock-breeding is an indispensable requirement for assuring adequate nutrition for the population. For proper nutrition about 50 grams of animal protein ought to be consumed per capita each day, but in Hungary the per capita consumption is only approximately 36 grams. Therefore, more meat products are needed in Hungary but developing the stock-breeding industry and increasing the available quantity of animal products are extremely complex and intricate tasks.

The successful development of stock-breeding is contingent upon improved management conditions, a better feed supply, proper animal hygiene, resarch concerning breeding, mechanization, and financial incentives as well as a closer cooperation between large-scale establishments and household plots. An abundance of animal products can be procured only through increased efficiency in the industry. The development of the industry must therefore proceed in this direction.

\section{BIBLIOGRAPHY}

Asztalos, 1. (1965). A takarmanytermesztès és állattenyésztés területi kapcsolata Magyarorszagon (Regional connection of fodder growing and stock-breeding in Hungary). Foldr. Ert. 1, Vol. 14. pp 73-92.

Asztolos. 1. (1966). Az allattenyésztés szerepe külkereskedelmi forgalmunkban (The role of stock-breeding in our foreign trade). - Földr. Közl. 4, Vol. 14. pp 276-298.

Ásztalos, 1. (1968). Az állattenyesztès területi megoszlása Magyarországon (Regional distribution of stock-breeding in Hungary). - Budapest: Akadémiai Kiadó. p 250.

Asztalos, 1. (1969). A magyar allattenyèsztès helye az európai állattenyèsztésben (Place of the Hungarian stock-breeding in European stock-breeding). - Földr. Ért. 4, Vol. 18. pp 457-479.

Bernát, T. and Enyedi, Gy. (1968). A mezōgazdasảg területi fejlōdésének fó jellemzōi 1935/39-1962/66 (Main characteristics of the regional development of agriculture). MTA Földrajztudamányi Kutató Int. Intézeti Munkajelentések, 3.

Bernat, T. and Enyedi, Gy. (1968). A magyar mezögazdaság területi fejlödésének néhány kèrdèse (Some questions of the regional development of Hungarian agriculture). Földr. Ért. 4, Vol. 17. pp 407-427.

Csizmadia, E., Dankovits, L. and Udvari L. (1968). A magyar mezögazdaság (The Hungarian agriculture). - Budapest: Kossuth Könyvkiadó. p 292.

Csizmadia, E. and Bethlendi. L. (1969). Korszerüsités ès jōvedelmezöség a mezógazdasảg. ban (Modernization and rentability in the agriculture). - Kögazdasági Szemle 7-8, Vol. 16. pp 855-867.

Gyori. M. (1966). A hazai húsellatás ès hústermeles (The inland meat supply and meat production). - Kozgazdasági Szemie 3, Vol. 13. pp 302-314. 
Hont, J. (1969). A mezögazdaság ès az élelmiszeripar fejlódésének föbb tendenciài (Major development tendencies in agriculture and the food industry). - Közazdasági Szemle 2, Vol. 16. pp 144-166.

Hont, J. (1969). A mezōgazdaság termelési szerkezetének lóbb változásai (Main changes in the structure of agricultural production in Hungary). - Közgazdasági Szemle 3. Vol. 16. pp 285-301.

Kiss, P. and Kralovánszky, P. (1962). A hústermelés és húsellátás kérdései hazánkban (Problems of meat production and meat supply in our country). - Budapest: Közgazdasági ès Jogi Kiadó.

Kulcsár, V. (1969). A magyar mezógazdaság területi kérdései (Regional problems of the Hungarian agriculture). - Budapest: Kossuth Konyvkiadó. p 202.

Mezôgazdasági Statisztikai Zsebkonyv 1960-1969 (Agricultural Statistical Monual 1960-1969). - Budapest: KSH.

Szederkenyi, A. (1966). A mezōgazdasági termelés szinvonalának összehasonlitása (Comparison of the level of agricultural production). - Statisztikai Szemle 3, Vol. 44. p 279-288.

Takács, J. (1965). Hüstermelesünk területi intenzitasa (Territorial intensity of our meat production). - Megyei es Városi Statisztikai Ertesitó 10, Vol. 15. 


\section{URBANIZATION TRENDS IN HUNGARY}

\section{E. LETTRICH}

According to the most generally accepted definition, urbanization means the complex process of economic, social and technical change, in the course of which ever increasing percentages of the population live in cities and urban agglomerations.

Important economic factors of this process are the advanced industrialization and agricultural development which permits a small number of the active population (5-15 percent) to produce a sufficient food supply for the entire society. In an industrialized society the overwhelming majority work in secondary and tertiary occupations. Thus they are bound to cities and urban agglomerations by their work, and therefore the majority of the population becomes city dwellers. The gradual territorial concentration of the non-agrarian work places therefore brings about a concentration of the population in urban centers. In countries where the urbanization is at an advanced stage, 70 to 80 percent of the population dwells in cities.

The cities and urban agglomerations which have grown large offer many and diverse opportunities for industrial and tertiary work, and ensure a wide choice of employments and for this reason they attract large numbers of population. At an advanced stage of urbanization the cities offer manifold opportunities for work in the service industries.

An important factor in both the economic growth and the further development of urbanization is a constant rise in the living standards of the masses. The urban way of life (i. e. advanced, civilized lifestyle) cannot be extended to the whole of society without such an increase in the standards of living. The other main factor in urbanization is townbuilding which has an outstonding role in the implementation of the urban land use. Its suitable development depends more closely than that of other factors on the level of technical development. Its special field is the metropolization which takes part in the creation of a metropolis - the main material establishment of urbanization - and as such it is in close interrelation with the more complex process of urbanization embracing the whole society and economic life. When townbuilding is not advanced, urbanization is hampered for lack of demands for new urban land use. Besides the main factors mentioned here, many other factors influence and shape the progess of urbanization. The examination of these factors is a complex task which must be done jointly by several branches of urban specialists. 
This essay examines urbanization from the view-point of settlement geography and endeavours to define the most important quantitatively measurable criteria. A triangle diagram has been used to analyse the changes that occurred in the occupational structure of the population between 1949 and 1960. Through empirical research threshold values were determined to define the 3 main types of communities according to the main occupation of the inhabitants. Subsequently every town and community was classified. The applied threshold values for the selection of the main categories and subtypes are the following:

1. Agrarian character - those communities where the proportion of agricultural earners (agrarquota) is higher than 55 percent.

2. Mixed character - those communities where the agrarquota is 33.6 to 55 percent.

3. Urban character - those communities where the agrarquota is less then 33.6 percent.

4. The advanced urban type communities where the agrarquota is $0-15$ percent.

The main features of the development between 1960 and 1970 have been based on data of population increase furnished by the 1970 census. The population growth change in the 1960 types has been analysed respectively in country district units and in some cases in country area divisions.

\section{Urban development between the two world wars}

Following World War I, the Austro-Hungarian Monarchy broke up and in the new political and economic situation Hungary having lost two thirds of her previous territory, struggled to overcome serious economic and social difficulties. Both the industry and the agriculture of Hungary were stagnant. The less developed industry could not absorb the strong agrarian population surplus. As Figure 1 points out the 58.3 percent agrarian earners in 1900 diminished only to 48 percent by 1941 while the proportion of industrial earners during this period grew from 15.6 percent to only 22.4 percent. The ratio of non-agrarian population to 100 agrarian earners also remained small. In 1900 this figure was 396 persons, while in 1941 it was 419 persons.

The fact that the agricultural territory allotted per capita to farms was very small also indicates the extreme agrarian over-population. Following the war the great and constant migration of refugees and masses of the surplus agrarian population created a new situation in the population distribution of the country. The only considerable large industrial centre 


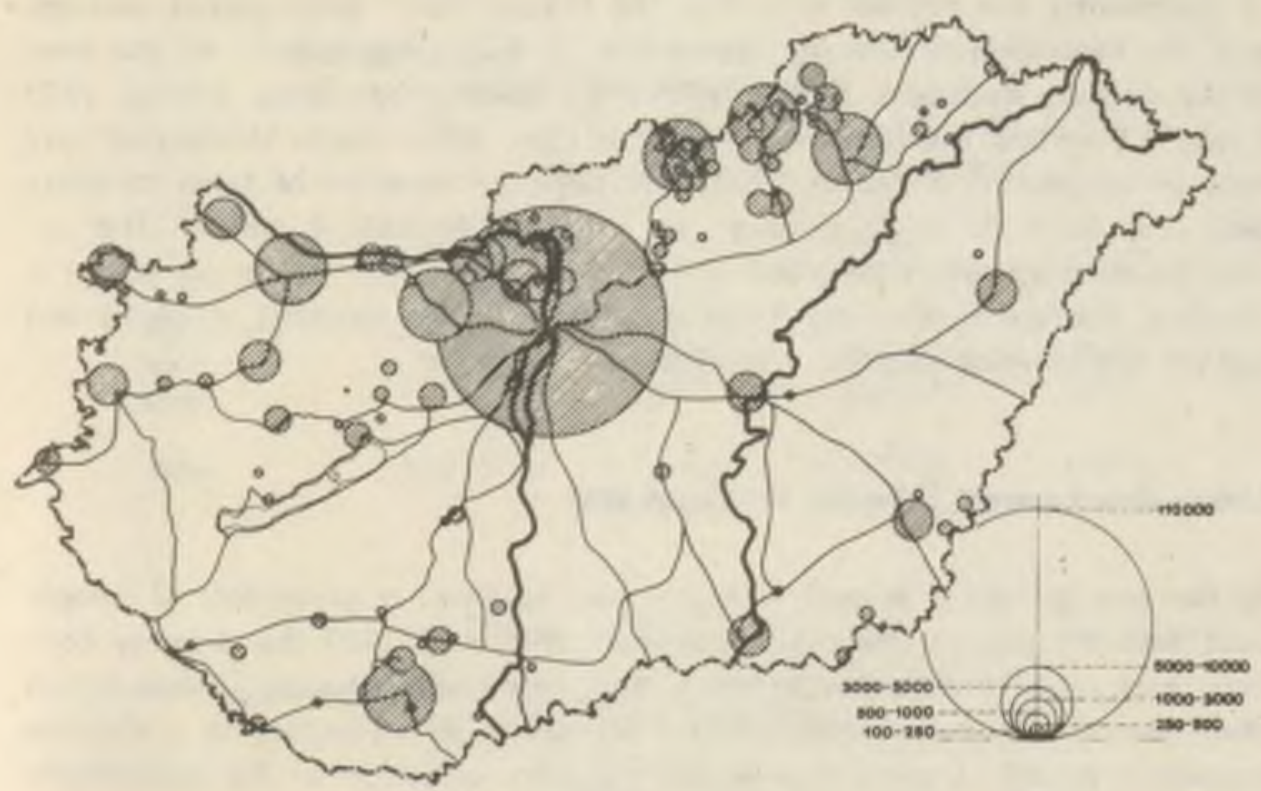

Fig. 1. Industrial works employing more than 100 persons in 1930 . The size of the circles marks the number of employees of the industrial units in accordance with the groups by size

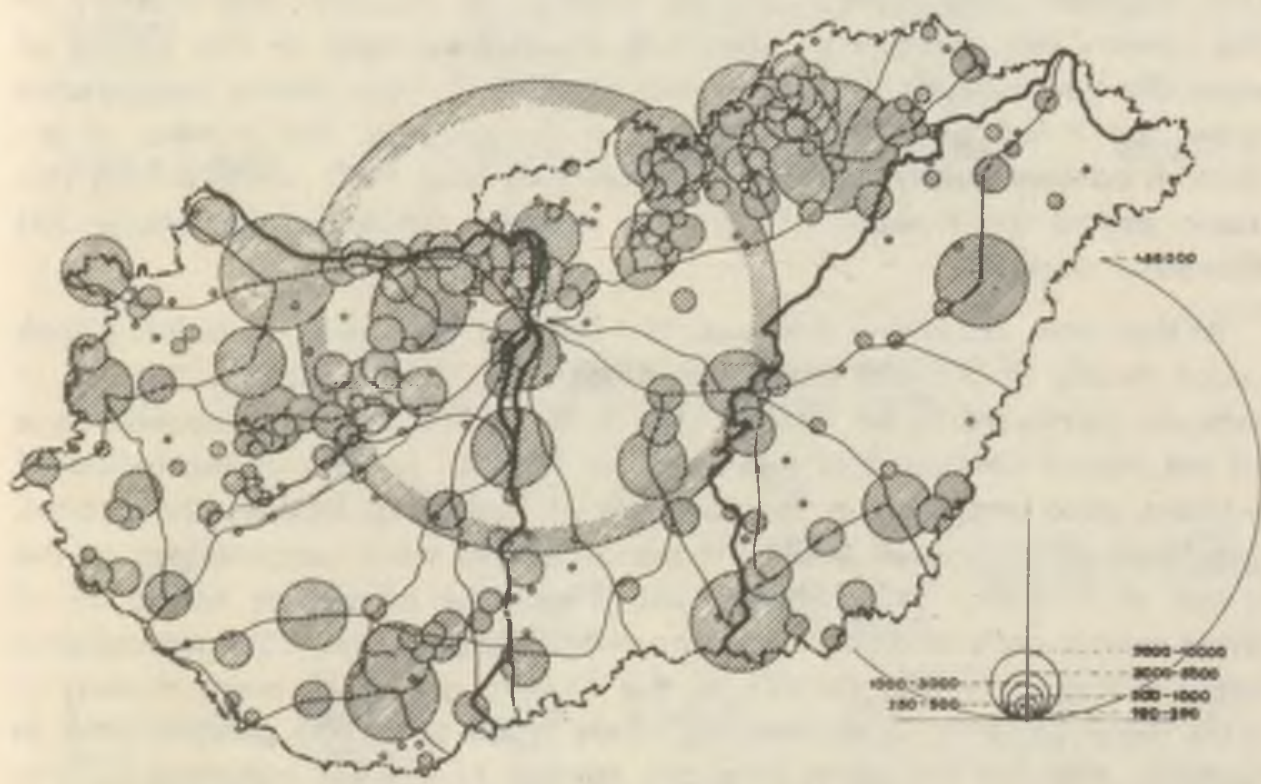

Fig. 2. Industrial works employing more than 100 persons in 1960 . The size of the circles marks the number of employees 
of the country, the capital, absorbed the thousands of employment seekers, and the formation of the agglomeration of Budapest began. At the turn of the century Budapest had only 860 thousand inhabitants, but by 1930 it had 1.5 million residents. At the same time, other towns developed very little or stagnated. Between 1900 and 1941 the number of town dwellers only rose from 40 to 42 percent, an increase of only 4 million. The industrial development connected with World War I, did not bring about a decisive change in the industrial structure of the country; it could not further the development of urbanization.

\section{Urban development between 1945 and 1960}

At the end of World War II Hungary had suffered a great lost of people and material wealth, therefore, between 1945 and 1959 the primary concern was reconstruction of industry and only the following comparatively short period of socialist development of industry has resulted in a decisive economic growth. During this period the transformation of the agricultural system caused basic changes in the agrarian life as well.

The industrialization as well as the transformation of the agrarian structure increased the trend toward reduction of the agrarian population and migration from agricultural occupations to industry. The industry of the country was capable of absorbing much manpower in this period of extensive development. The manpower attraction of the service occupations grew, but it lagged well behind that of the industry. The number of industrial earners nearly doubled between 1949 and 1960, while during this same period the number of agrarian workers diminished by nearly 300 thousand persons.

At that time, as Figure 2 shows, the socialist expansion of industry took place mostly in the old industrial areas and the territorial division of industry continued to be uneven. The unhealthy economic preponderance of the capital continued to exist, and by 196045 percent of the industrial workers were employed in the factories of Budapest. Besides the capital, industries employing 20 to 24 thousand earners were concentrated in the areas of Miskolc, Györ, Szeged and Pécs. The manpower attraction of these towns drew a rather large number of commuters from surrounding areas. Other industrial centres of the country are much more modest in size. There are only 11 settlements where 5.000 to 20.000 persons work in industry, while at the same time the number of smaller industrial centres is quite high. The majority of them are thinly populated mining villages in the Hungarian Mountains. 
Table 1.

THE PROFESSIONAL STRUCTURE OF THE RECTIVE POPULATION 1949 AND 1960

\begin{tabular}{lrrrr}
\multicolumn{1}{c}{ Branch } & \multicolumn{2}{c}{1949} & \multicolumn{2}{c}{1960} \\
& earners & $\%$ & camers & \% \\
& & & & \\
Agriculture & $2,196.185$ & 49,8 & $1,925.100$ & 40,8 \\
Industry & 963.493 & 21,9 & $1,682.233$ & 35,8 \\
Other & $1,249.621$ & 28,3 & 1,102567 & 23,4 \\
& & & & \\
Total & $4,409.299$ & 100,0 & $4,709.900$ & 100,0
\end{tabular}

Table 2.

PROPQRTION OF THE POPULATION IN THE VARIOUS TYYPES OF COMMUNITIES IN 1949 AND 1960

\begin{tabular}{lrrrr} 
Types of communities & \multicolumn{2}{c}{1949} & \multicolumn{2}{c}{1960} \\
& head & $\%$ & head & $\%$ \\
& & & & \\
1. Agrarian & $4,880.808$ & 53,1 & $3,512.094$ & 35,2 \\
2. Mixed & 898.505 & 9,7 & $1,566.952$ & 15,7 \\
3. Urban & $3,425.486$ & 37,2 & $4,897.484$ & 49,1 \\
4. Budapest & $1,589.065$ & 17,3 & $1,807.299$ & 18,1 \\
& & & & 100,0
\end{tabular}

Table 3.

THE POPULATION DECREASE OF COMMUNITIES OF AGRARIAN CHARACTER (1960-1970)

1960

Area head

1970

\begin{tabular}{|c|c|c|c|c|c|c|}
\hline Area & head & $\begin{array}{l}\text { percentage } \\
\text { of the total } \\
\text { population }\end{array}$ & head & $\begin{array}{l}\text { percentage } \\
\text { of the total } \\
\text { population }\end{array}$ & $\begin{array}{c}\text { Decrease } \\
1960-1970\end{array}$ & $\begin{array}{c}\text { Index } \\
1960=100\end{array}$ \\
\hline Transdanubia & $1,258.345$ & 41,8 & $1,181.960$ & 38,1 & 76.385 & 89 \\
\hline North & 389.767 & 29,7 & 378.146 & 27.6 & 11.621 & 91 \\
\hline Great Plain & $1,863.982$ & 48,5 & $1,717.292$ & 44,5 & 146.690 & 94 \\
\hline $\begin{array}{l}\text { Total in } \\
\text { Hungary }\end{array}$ & $3,512.094$ & 35,2 & $3,277.398$ & 31,8 & 234.696 & 92 \\
\hline
\end{tabular}


Approximately two-thirds of the industrial population of the country works near the Danube from the western frontier to the southern fringe of the agglomeration of the capital and in the industrial concentrations in the mining areas of the Hungarian Mountains. These territories have become the most progressive in urbanization. Their populations grew quickly in the wake of the intensification of their manpower attraction: the number of dwellings increased, and even the employment in service occupations grew. In areas away from the industrial belt, zones were gradually formed where the occupational structure of the population changed very slowly and so the population either grew sparsely or stagnated. In about half of the territory of the country in the agrarian settlements an intense out-migration (Landflucht) occured which resulted in a decrease of the population in the settlements concerned. The surplus agrarian population of these areas migrated to the territories becoming industrialized.

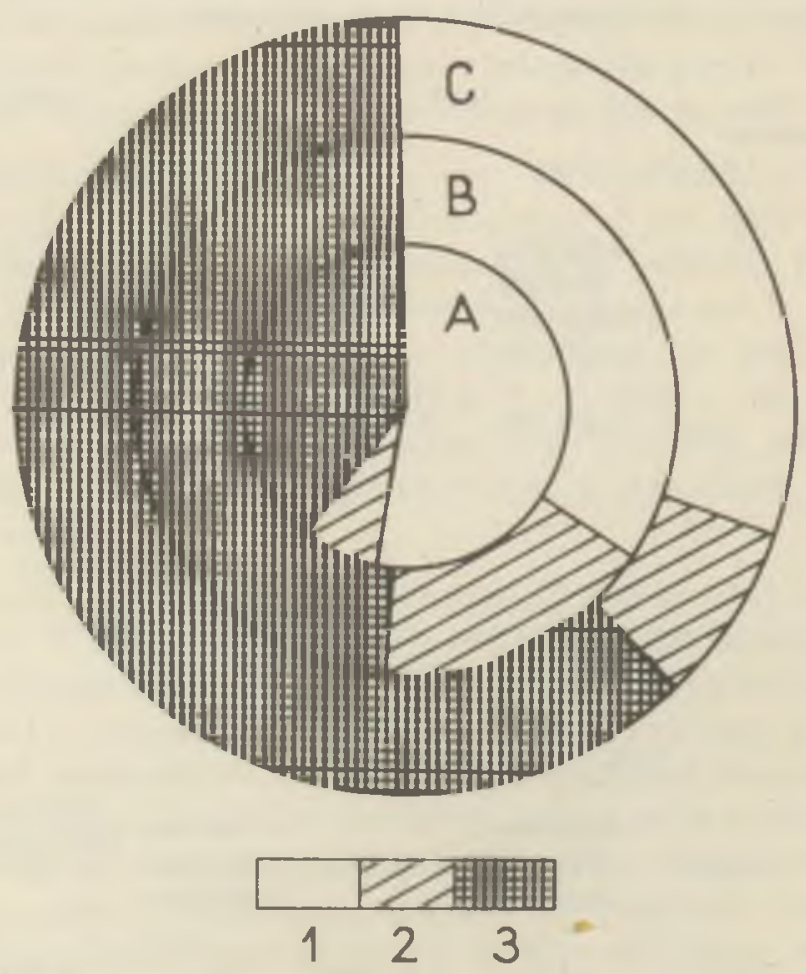

Fig. 3. The change of the number of the inhabitants of agrarian, mixed and urban character between 1949-1960-1970. Inhabitants of settlements of $1=$ agrarian character; $2=$ mixed character; $3=$ urban character; $A, B, C=$ periods (years) : $360^{\circ}=$ the total inhabitants of the country 
The process of change in the occupational structure greatly influenced the modification in the way of life of the population. It lifted huge masses of people from their original dwelling places and placed them into strange living conditions. Figure 3 depicts the great change in the division of the population of the country, in agrarian, mixed and industrial settlements between 1949 and 1960. The population of agrarian settlements obviously has significantly diminished in favour of urban and mixed settlements.

One of the characteristic features of urbanization in this period was that it overemphasized industrial development and its uneven territorial division greatly influenced the progress of urbanization. Another feature was the multidimensional role of the capital. The expanding agglomeration of Budapest constitutes an ever increasing concentration of job opportunities, dwelling places and population. In 1960 its total population reached 2.3 million, or 23 percent of the whole population. An even greater concentration of tertiary employments exists in Budapest and thus the capital has an exaggerated importance in both industrial and service networks of the country. In Hungary only a few large or medium-sized towns ( 80 to 200.000 dwellers) can be found and the sum total of the inhabitants of these towns hardly approaches the number of inhabitants in the agglomeration of Budapest. Though they have achieved a significant increase in population attempts at transforming these towns into urban centres so far have not succeeded because they have not developed an attraction area strong enough to compete with that of the capital. The small-town network of Hungary is undeveloped. Its lack of tertiary occupations and backwardness in building dwelling places considerably hampers it in fulfilling its central place functions. This situation also accounts for the stagnant number of inhabitants or the small scale of the transmigrations.

\section{Urban development between 1960 and 1970}

The urbanization process that evolved in the fifties gained momentum in the sixties and the migration of the population to the towns is constantly increasing. Numerous factors contributed to this development, but the major causes can be summarized as follows:

1. In the last decade the building industry developed greatly and became able to quickly expand and modernize the available supply of flats. Thus, the number of new flats in the towns increased by leaps and bounds.

2. Due to the collectivization process that took place in Hungarian agriculture between 1960 and 1963, large farms were formed from numerous small holdings. This process strengthened the considerable out-migration 

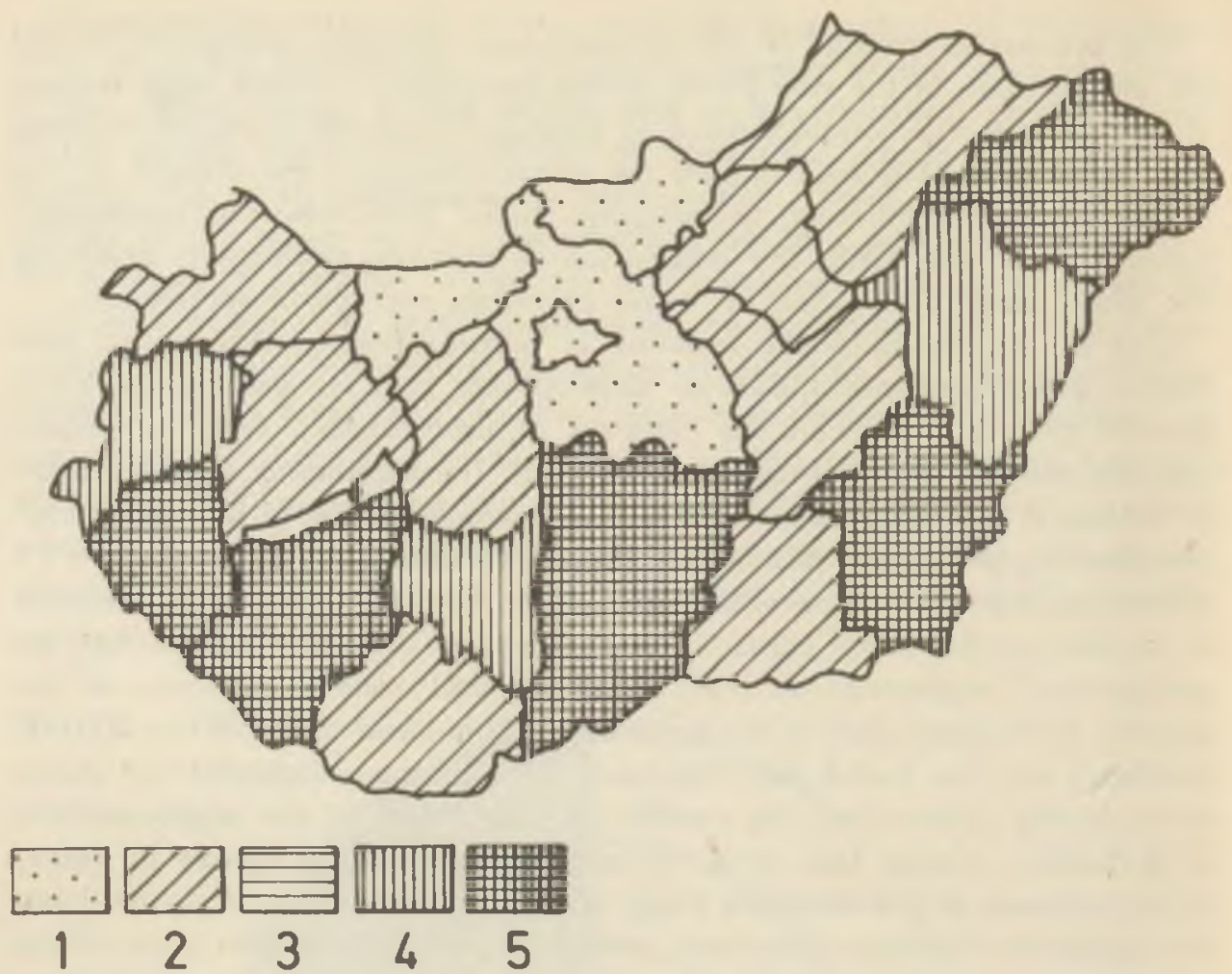

Fig. 4. Percentage of inhabitants of the settlements of agrarian character as comparea to the total inhobitants of the counties in 1970. $-1=5-25 \%, 2=26-35 \%, 3=36-$ $45 \%, 4=46-55 \%, 5=55-75 \%$

and in a few years it diminished the proportion of agrarian wage earnes. As depicted in Figure 4, in 1967 the proportion wage earners was only 30.9 percent, but by 1970 the number had decreased to 27 percent. While the out-migration was eliminating the surplus in agrarian workers technology began making an important impact on agricultural production. Due to the modernization and the many-sided structural transformation of agriculture, the vertical ingtegration (agribusiness) is not taking place. Due to its vertical nature the agrarian production constitutes an organic whole with many industrial and other non-agrarian activities.

In the second half of the sixties, the period of extensive developing of industries essentially was over and the new economic mechanism was introduced in an attempt to raise the effectivness and the output of the production. This new policy has had a direct impact on the occupational structure of the population. In the course of the development of modern technology the importance of coal production is deminishing as hydrocarbon - crude oil and natural gas - are becoming more important. There- 


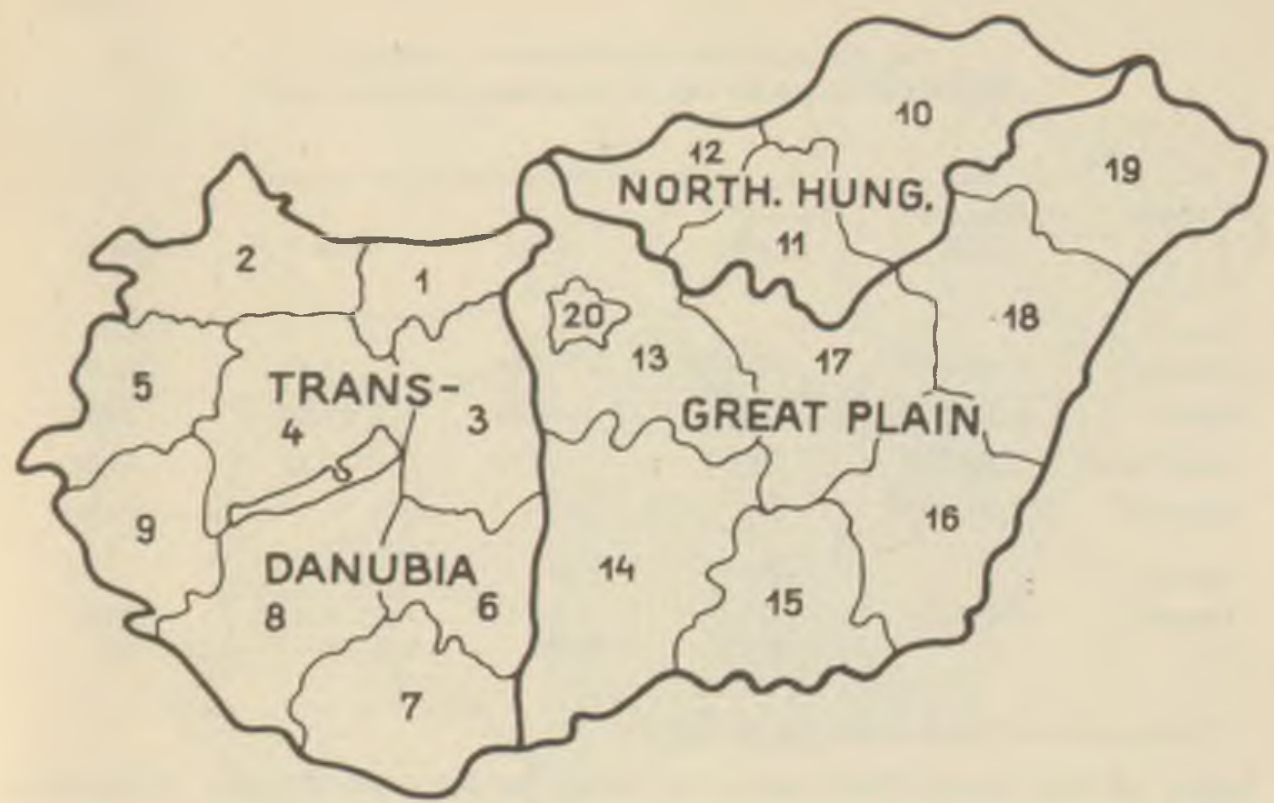

Fig. 5. The counties and regions of the country. - Transdanubia: $1=$ Komárom; $2=$ Gyôr; 3 = Fejér; 4 = Veszprém; 5 = Vas; $6=$ Tolna; $7=$ Baranya: $8=$ Somogy; 9 = Zala: North: 10 = Borsod; 11 = Heves; 12 = Nógrád; Great Plain: 13 = Pest; $14=$ Bács; $15=$ Csongrád; $16=$ Bèkès; $17=$ Szolnok; $18=$ Hajdủ; $19=$ Szabolcs; 20 = Budapest

fore the urbanization of previously attractive coal-mining territories came to a halt and in some places the urban population declined. Simultaneously, the pace of flat-building, the expansion of secondary and tertiary occupations and the corresponding concentration of the population considerably intensified in 6 major urban agglomerations of the country - Budapest, Miskolc, Debrecen, Szeged, Pécs and Gyôr. The manufacturing industry - especially the machine-tool making forged ahead and the speedy development of the tertiary branches increased even in the small and medium-sized towns which became the scene of a growing influx of population (Figure 5).

With this trend a more even period of urbanization has started which is more organically bound to the network of towns than the previous one. As Table 4 indicates the number of inhabitants in agrarian, mixed and urban types of settlements was modified accordingly.

In this structural transformation of employment the inner migration of the population increased and the great transmigration which already was characteristic of rural territories continued to increase. Thus, from Figure 6 it is obvious that the regions of disposed farmsteads and the giant vil- 
THE POPULATION OF DIFFERENT TYPES OF SETTLEMENTS AND THEIR REGIONAL PERCENTAGE ${ }^{\star}$

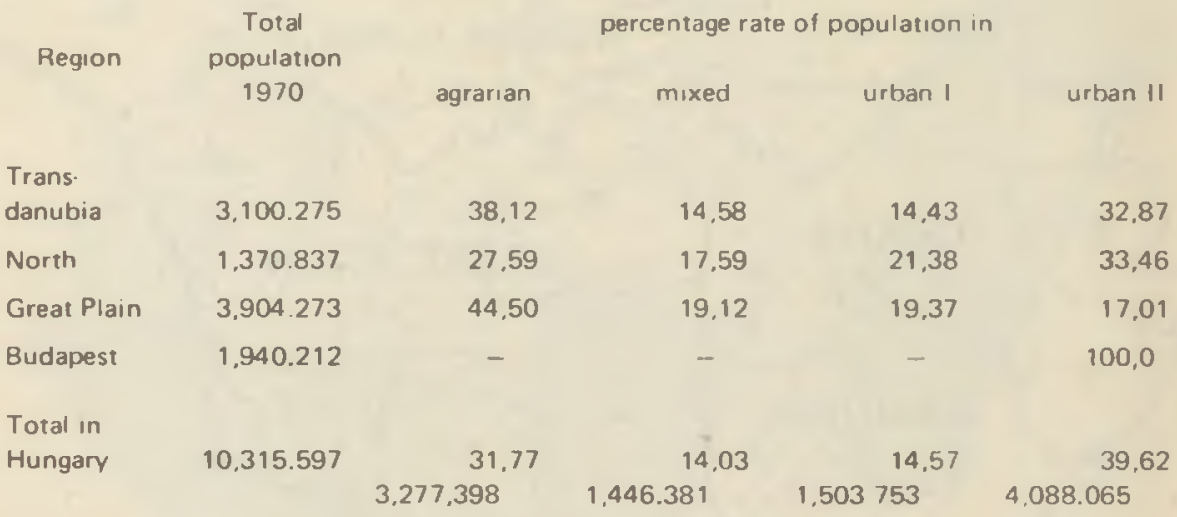

${ }^{x}$ For the criteria of typology see page 222

lages of the Great Plain were the areas which considerably diminished between 1960 and 1970 (Figure 6). The population of the isolated farmsteads has diminished by about 260 thousand during the last 10 years. In 1970, the majority of the nearly 800 thousand inhabitants of the dispersed farmsteads of the country lived in the Csongrád and Bács counties where, because of the intensive horticulture, the small, private farm system seems to be lasting whereas in other parts of the Great Plain - Bèkes, Szabolcs, Hajdu - where there is a different structure of production, the dispersed farmstead system is dying out.

The increase or decrease in the population of certain regions between 1960 and 1970 was primarily caused by the strong internal migration. Figure 7 shows the real population increase during this period. Northern Transdanubia, the North and the agglomeration of the capital greatly increased in population to the detriment of the other territories.

The new stratification of professions and the internal migration resulted in a change in both the quantitative and the qualitative structure of the settlement network.

Besides the outflux of the agrarian surplus population from small villages with less than 1000 inhabitants it was the formation of the agglomeration of the capital that brought about the first decisive change in the structure of the settlement network at the turn of the century. The town development of the present urbanization period has a similar significance because as Figure 8 and Table 5 indicate more than half of the country's population is dwelling in settlements where the number of inhabitants exceeds ten thousand. 


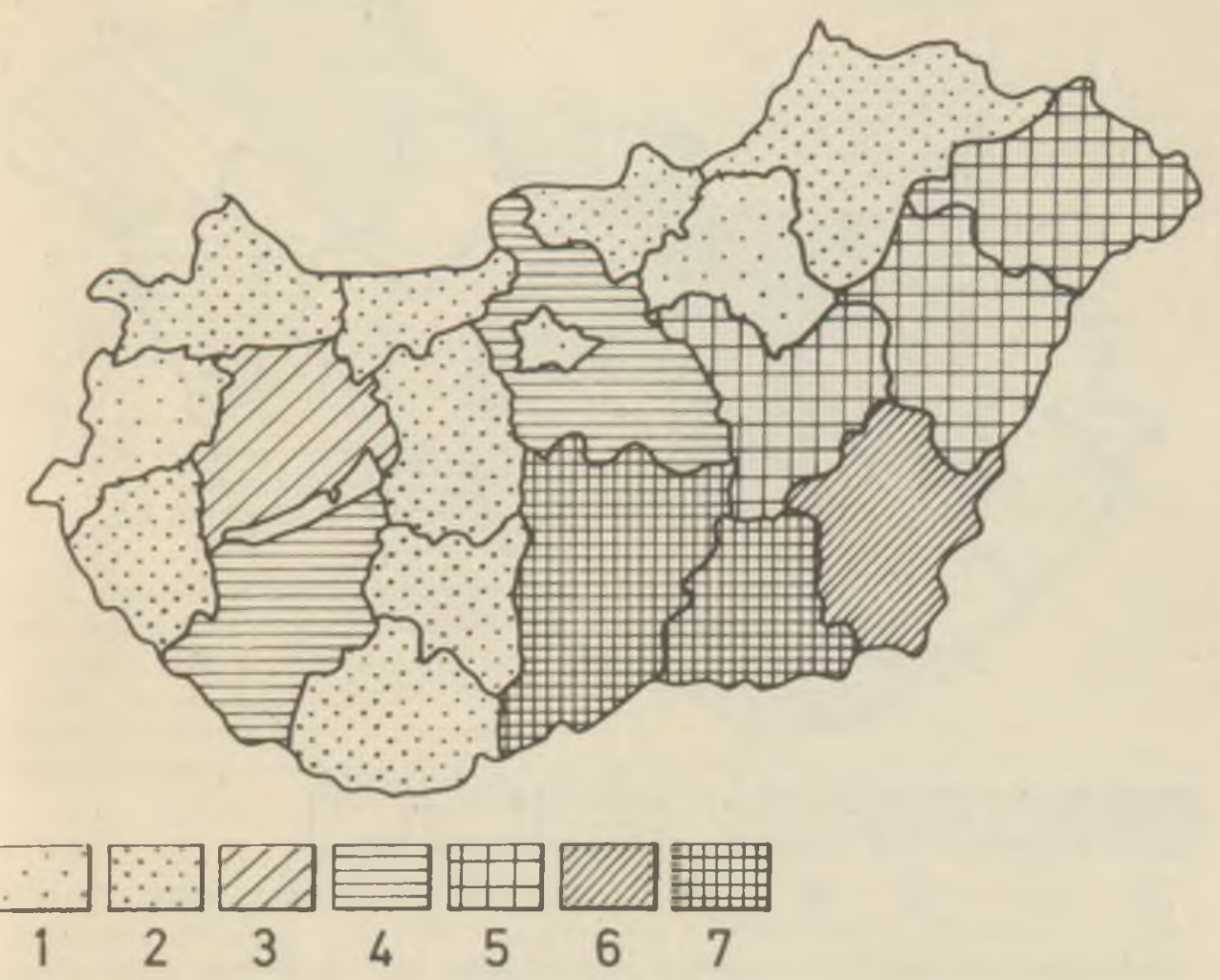

Fig. 6. Percentage of periphery population of the individual counties in $1970 .-1=0,1-$ 3,$4 ; 2=3,5-6,4 ; 3=6,5-8,4 ; 4=8,5-10,4 ; 5=10,5-15,4 ; 6=15,5-20,0 ; 7=20,1-$ $30 \%$

Among settlements of more than ten thousand inhabitants, the settlements of central function forming the town-network are predominant, but their development is not even in all cases. Those with more than fifty thousand inhabitants - usually the administration centres of counties developed most rapidly because in the past decade these towns were the main scenes of new construction and the development of an institutional network. In connection with this growth medium-sized towns began to grow. The small towns with an average population of 25 to 35 thousand - also made a step forward. Even though they lagged behind the pace of progress in larger towns, their institution network did expand and therefore their attraction power increased. Today the remnants of old traditions can be found only on the Great Plain where there is a higher proportion (25 to 35 percent) of agrarian dwellers in certain towns.

In Hungarian villages significant changes which modified both the size 

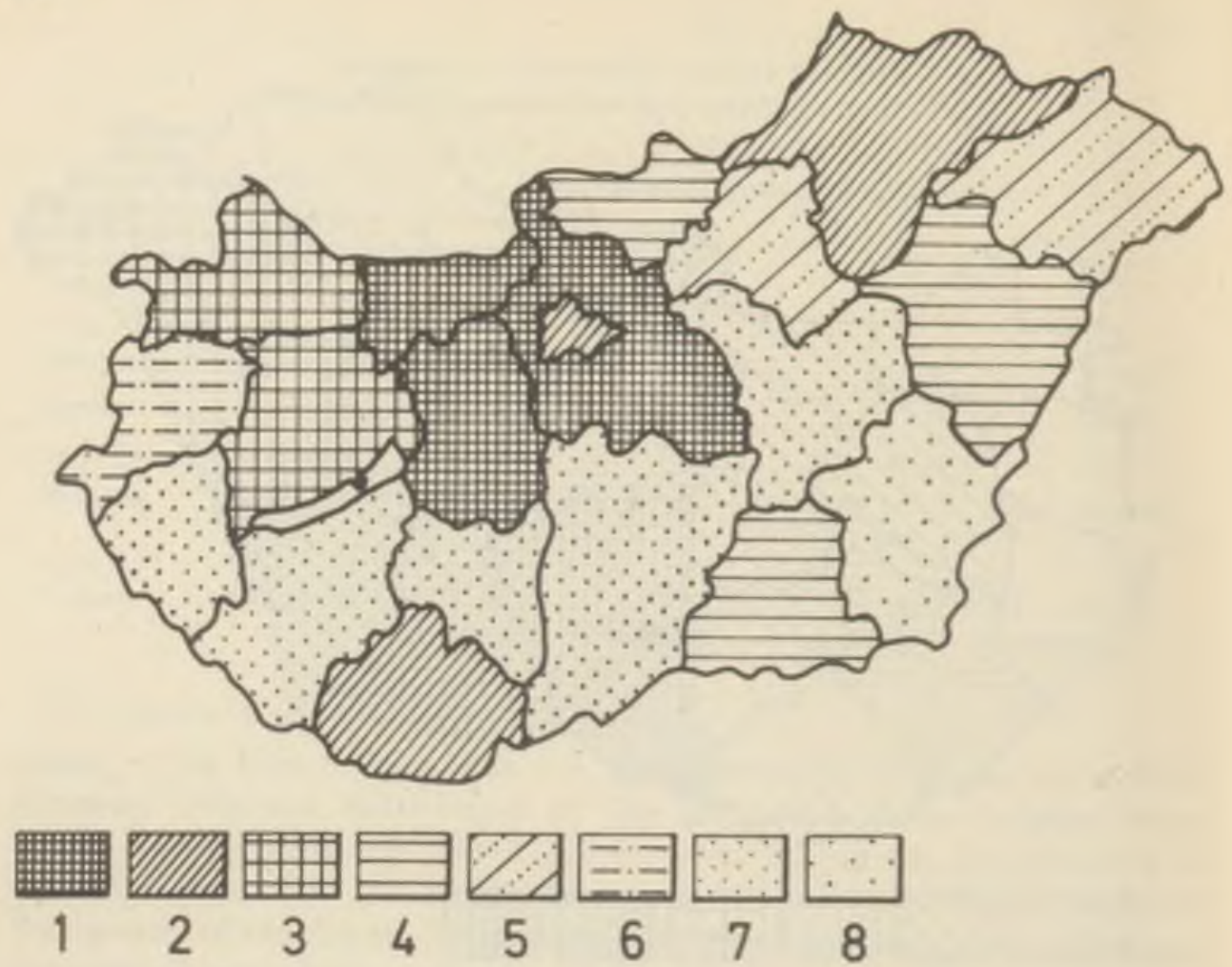

Fig. 7. The real population increase of the individual counties between 1960-1970. Increase: $1=8-15 \% ; 2=5,5-5,4 ; 3=3,5-5,3 ; 4=1,5-3,4 ; 5=0,1-1,4$; Decrease: $6=0,1-1,4 ; 7=1,5-3,4 ; 8=3,5-5,0$

Table 5.

THE DISTRIBUTION OF POPULATION FROM 1789-TO 1970 IN PERCENT

Population of settlements

$$
\text { Years }
$$

1787

1920

1949

1960

1970

500 and less
$500-1000$
$1000-2000$
$2000-3000$
$3000-5000$
$5000-10000$
10000 and more

19,4

26,5

3,5

21,7

9,1

2,2

2,4

2,1

$1 \quad 15,7$

6,9

13,0

6,5

5,9

8,5

9,8

9,5

12,6

11,3

6.2

12,2

8,8

8,3

8,4

१2, 1

11,0

11,2

9,3

39,3

44,1

10,5

48,2

10,4

10,4

51,6

Total

100,0

100,0

100,0

100,0

100,0 

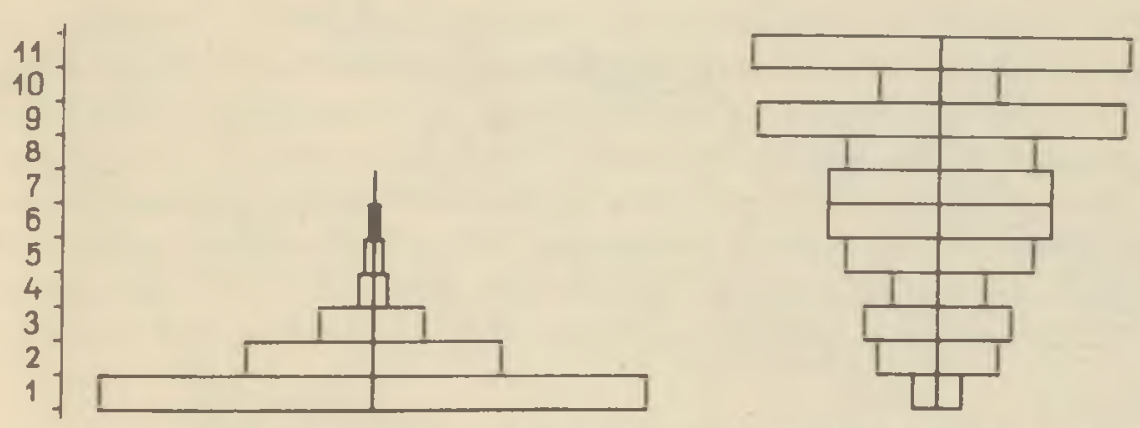

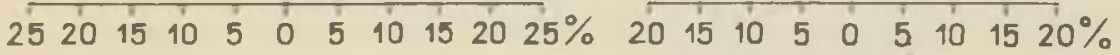

Fig. 8. Diagram of size structure of the settlement network in 1787 and 1970. - Settlement orders: $1=1-500$ inhabitants; $2=500-1000 ; 3=1001-1500 ; 4=1501-2000$; $5=2001-3000 ; 6=3001-5000 ; 7=5001-10.000 ; 8=10.001-20.000 ; 9=20.000-$ $100.000 ; 10=100.001-200.000 ; 11=$ above 200.000 . On the vertical axis the total length of the band chart - the total sum of the percents to the right and to the left from the 0 point - gives the proportion of population of the individual settlement orders from the total population of the country

and character of our rural settlement network also have occured. The most important changes are: the accelerating depopulation of small villages which have less than 500 inhabitants; the slow but constant population loss of villages of 1000 and 2000 inhabitants; and the stagnation of more populated villages as a result of the strong population migration towards the towns. On the other hand in the residential communities population has increased and an ever increasing amount of one family dwellings are being built there. In many villages considerable progress has been achieved in the development of public utilities, retail trade and institution supply and these developments may provide many dwelling communities with urban life. The process of urbanization has not been of equal intensity in all parts of the country in the last decade but a certain moderation of the excesses of the last decade can be seen. This trend is depicted in the Figure 9. which shows the division of population among agrarian, mixed, urban I. and urban II. settlements in each country in 1970.

The influences which lead to changes in the occupational structure of the population are most evident in Pest County and in its western neighbour, the strongly industrialized Komárom County where only 11 to 13 percent of the county's population lives in communities of agrarian character. In these countries the proportion of communities of mixed character is also low, ranging from 6 to 17 percent while at the same time, 


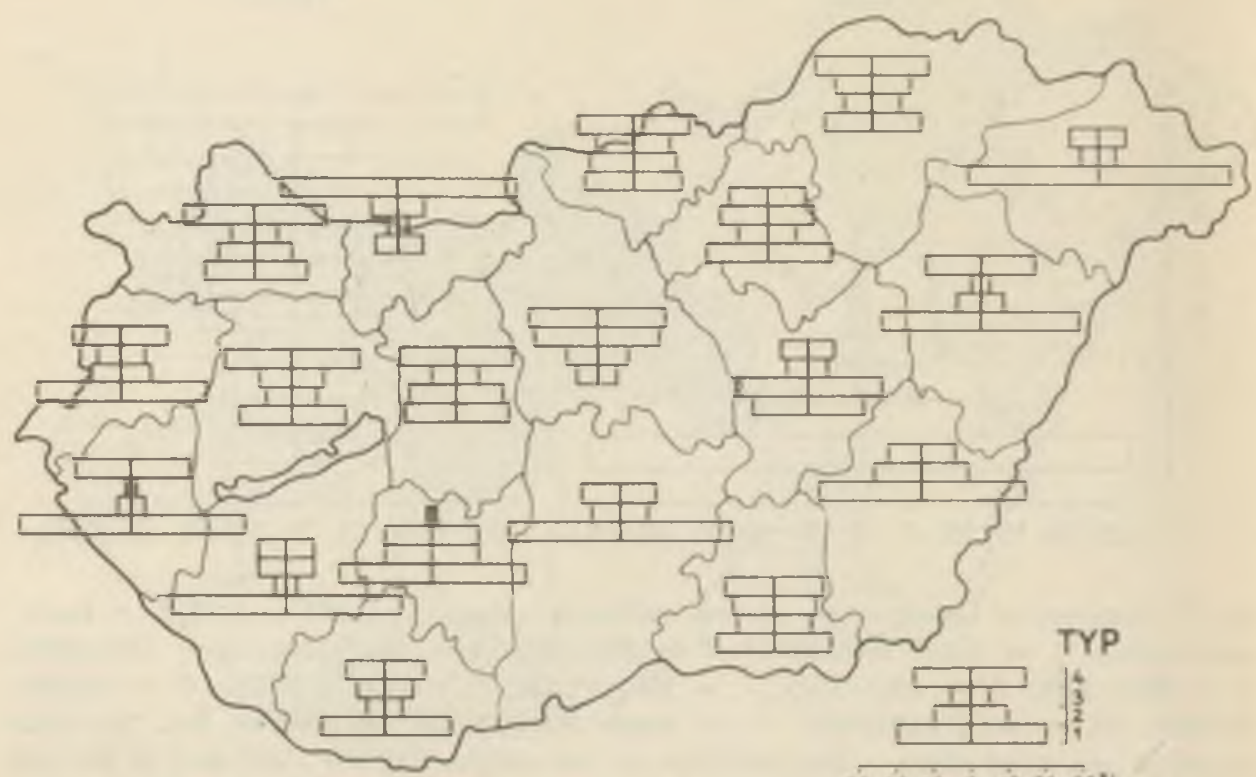

3020100 iी $2030 \%$

Fig. 9. The division of population of the counties between the agrarian, mixed and urban communities of the county in 1970. On the vertical axis: types of communities: $1=$ agrarian; $2=$ mixed; $3=$ urban I.; $4=$ urban II. (their agrarquota $1=$ above $55 \%$. $2=33,5-55 \%, 3=15-33,5 \%, 4=0-1.5 \%$ ), on the horizontal axis the total length of the band chart - the total sum of the percents to the right and to the left from the 0 point - marks the proportion of population attaching to the individual types of community as compared to the total population of the county

more than two-thirds of the population lives in urban settlements among which the urban type II. is dominant.

The heavely industrialized counties of Györ, Veszprem, Fejér, Borsod, Nográd and Csongrád are in second place according to their level of development. Among these there is only one Great Plain county, Csongrad. In this particular county a large quantity of crude oil and natural gas recently has been discovered. The other counties lie in Northern Transdanubia and the northern industrial region of the country.

The progress of urbanization is slow in the other counties which comprise more than half of the territory of the country. The slow progress of the change in the settlement size and occupational structure is especially conspicuous in the counties near the frontier (Szabolcs, Hajdú, Bács, Békés. Zala, and Somogy) some of which (Bács, Bèkés, and Szabolcs), due to their industrial backwardness, do not even possess one highly developed urban settlement (category 4). 


\section{Future trends in urbanization}

On January 1, 1970, the number of inhabitants in Hungary reached approximately 10 million (Census data). At that time the population densitly had risen to 111 persons per square kilometer, exceeding that of all other East Central European countries. The pace of population increase has slowed down excessively the last decade, and improvement in the growth rate cannot be expected by the end of the coming decade, because with the ageing of the population, the pace of the increase will not even reach the yearly 0.35 percent rate of the last decade. Even if this natural increase

Table 6.

THE DIVISION OF THE POPULATION OF THE COUNTIES AMONG THE DIFFERENT TYPES OF SETTLEMENTS IN 1970

\begin{tabular}{|c|c|c|c|c|c|c|}
\hline \multirow{2}{*}{$=$} & \multirow{2}{*}{ County } & \multirow{2}{*}{$\begin{array}{c}\text { Total } \\
\text { Inhabıtants } \\
1000 \text { persons }\end{array}$} & \multicolumn{4}{|c|}{$\begin{array}{l}\text { The percentage rate of population in } \\
\text { various types of towns and communities }\end{array}$} \\
\hline & & & agrarıan & mixed & urban I & urban II \\
\hline 1 & Komarom & 3018,5 & 13,23 & 6,25 & 15,96 & 64,55 \\
\hline 2 & Gyór & 4046,9 & 28,17 & 20,83 & 12,33 & 38,67 \\
\hline 3 & Fejér & 3889,1 & 28.57 & 27,10 & 13,62 & 30,41 \\
\hline 4 & Veszprem & 4089,9 & 29,82 & 14,66 & 17.26 & 38.25 \\
\hline 5 & Vas & 2808.4 & 46,30 & 13,13 & 11.82 & 28,75 \\
\hline 6 & Tolna & 2592,6 & 51.23 & 23,45 & 23,50 & 1.85 \\
\hline 7 & Baranya & 4250,2 & 32,79 & 10,07 & 16,32 & 40,82 \\
\hline 8 & Somogr & 3635.1 & 62,76 & 6,07 & 15.90 & 15,27 \\
\hline 9 & Zala & 2671,8 & 61,59 & 7,37 & 1,63 & 29,41 \\
\hline 10 & Borsod & 7813,2 & 25,48 & 13,54 & 21.41 & 39,57 \\
\hline 11 & Heves & 3483,9 & 34,24 & 16,98 & 26,27 & 22,51 \\
\hline 12 & Nográd & 2311,2 & 24,78 & 23,22 & 22,51 & 29,49 \\
\hline 13 & Pest & 8698,6 & 11,14 & 17.83 & 33.08 & 37,95 \\
\hline 14 & Bacs & 5729,8 & 62,18 & 15,51 & 22,31 & - \\
\hline 15 & Csongrád & 4417,2 & 31,34 & 19,08 & 22,76 & 26,82 \\
\hline 16 & Bekes & 4471,9 & 57,33 & 24,41 & 18,26 & - \\
\hline 17 & Szolnok & 4498,3 & 32,96 & 39,76 & 12.54 & 17,74 \\
\hline 18 & Haıdu & 5304,9 & 53,80 & 12,85 & 4,11 & 29,24 \\
\hline 19 & Szabolcs & 5921,86 & 73,56 & 11,67 & 14.77 & - \\
\hline 20 & Budapest & 19402,1 & - & - & - & 100 \\
\hline otal & ungary & 103155,9 & 31.77 & 14.04 & 14,57 & 39,62 \\
\hline
\end{tabular}

accelerates and exceeds the rate of the sixties, there cannot be a significant improvement in the unfavourable age-composition of the country. While the proportion of 0 to 14 year olds fell from 34.9 percent in 1900 to 21.2 percent by 1970 , the proportion of the over-sixty age group rose from 7.5 percent to 16.9 percent and this proportion will increase in the future. 
The next phase in the development of the economic bases of urbanization will be modernization and intensive development, technological development of existing industries. In the structural change of Hungarian industries it will be especially the change in the energy-structure which will bring future development. The transformation of our agriculture to a vertically integrated one is progressing systematically, while the proportion of our agrarian earners is continually diminishing and by 1980 probably will sink below 20 percent of the active population which is the present level of some of the advanced West European countries. Statistical projections indicate that in 20 to 30 years it will stabilize at about 10 percent. In the present situation a lower agrarquota cannot be expected. The Hungarian infrastructural development is the cause of greatest concern because of its high investment demands. The further development of the tertiary branches is closely connected with the developments in this field.

By 1980 a further increase in the proportion of urban inhabitants can be expected. The populations of settlements of agrarian character will diminish from 3 millon (1970) to 1.5 million (1980). At the same time, the population growth and the corresponding increase in housing construction will be concentrated in the agglomeration. Thus, by the end of the next decade the urban population may rise from 54 percent to 65 or 70 percent.

\section{BIBLIOGRAPHY}

Bobek, H. (1968). Erwerbestruktur und Dienstenquote als Mittel zur quantitativen Erfassung regiondiler Unterschiede der sozialwirtschaftlichen und kulturellen Entwicklung. - Hartke-Festschrift. K. Rupper ed. München. pp 119-131. (Münchener Studien zur Social- und Wirtschaftsgeographie 4.)

Fouradtie, J. (1952). Le grand espoir du XXe siecle. - Paris: Presses Universitaires de France.

Lettrich, E. (1965). Urbanizálódás Magyarországon (Urbanization in Hungary). - Budapest: Akadémiai Kiadó, p 83. (Földrajzi tanulmányok 5.)

1970. évi népszámlálás. 1. Elózetes adatok (Census of the year 1970. 1. Preliminary data).

- Budapest: KSH. p 373. 


\section{THE TOURIST TRADE IN THE BALATON RESORT DISTRICT}

\section{B. GERTIG}

The tourist trade in Hungary largely evolved after World War II. In the first decade following the war the tourist traffic developed slowly and was almost entirely restricted to internal traffic.

During the second half of the 1950s the domestic tourist trade began developing, and after 1960 the international tourist traffic assumed continually increasing proportions. It increased almost six times, surpassing the growth rate of the tourist industry of Europe. In 1960 the Hungarian resorts only received 0.46 percent of the total European tourist trade, but by 1968 it attracted 2.53 percent of the European foreign tourist traffic, which in the meantime increased nearly 200 percent (Table 1).

Table 1.

FOREIGN TOURIST TRAFFIC in HUNGARY and in EUROPE BETWEEN 1958 and 1969

\begin{tabular}{|c|c|c|c|c|c|c|c|c|c|}
\hline \multirow{2}{*}{ Year } & \multirow{2}{*}{$\begin{array}{l}\text { Europe } \\
\text { mil- } \\
\text { lions }\end{array}$} & \multicolumn{3}{|c|}{ Hungary } & \multirow{2}{*}{$\begin{array}{l}\text { Euro- } \\
\text { pe }\end{array}$} & \multicolumn{3}{|c|}{$\begin{array}{c}\text { Hungary } \\
\text { Index: } 1960=100\end{array}$} & \multirow{2}{*}{$\begin{array}{l}\text { Hungary } \\
\text { Participation } \\
\% \text { in the } \\
\text { foreign } \\
\text { tourist } \\
\text { traffic of } \\
\text { Europe }\end{array}$} \\
\hline & & $\begin{array}{l}\text { en- } \\
\text { tering }\end{array}$ & $\begin{array}{l}\text { in- } \\
\text { transit }\end{array}$ & total & & $\begin{array}{l}\text { en- } \\
\text { tering }\end{array}$ & $\begin{array}{l}\text { in- } \\
\text { transit }\end{array}$ & total & \\
\hline 1958 & 50 & 154 & 163 & 317 & 93 & 63 & 58 & 60 & 0,30 \\
\hline 1960 & 54 & 244 & 280 & 524 & 100 & 100 & 100 & 100 & 0,45 \\
\hline 1965 & 88 & 1319 & 816 & 2135 & 163 & 541 & 291 & 407 & 1,47 \\
\hline 1968 & 95 & 2404 & 1903 & 4307 & 176 & 985 & 680 & 822 & 2,53 \\
\hline 1969 & - & 3002 & 3067 & 6069 & - & 1230 & 1095 & 1158 & - \\
\hline
\end{tabular}

In 1968 the number of foreigners choosing Hungary for their destination approached two and half million while in 1969 it exceeded more than three million. The number of foreigners travelling in transit through Hungary, a country situated at a point of intersection of the European foreign tourist traffic in general remained below the number whose destination was Hungary.

In order to be able to satisfy the rapidly increasing demands for accommodations the number of rooms available in the resorts has been considerably increased.

In 1968 the housing capacity was more than the double that of 1960 . The facilities available to foreign tourists have been expanded at a rate 
THE NUMBER OF ACCOMODATIONS, VISITORS and VISITORS DAYS in HUNGARIAN RESORTS

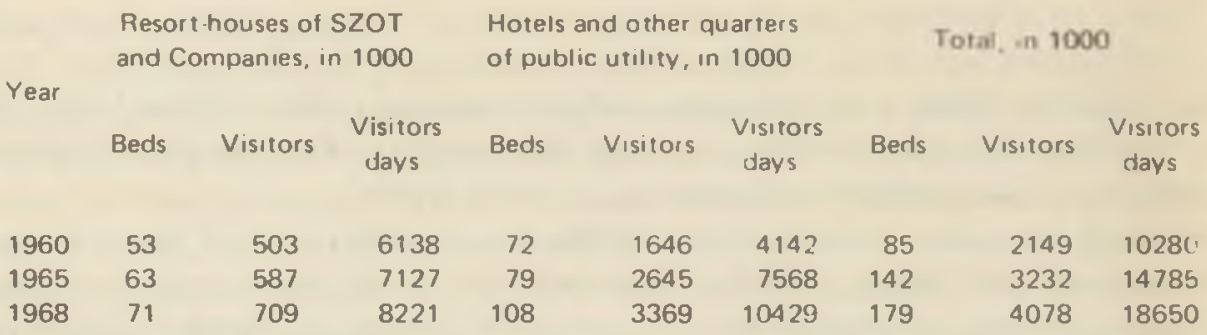

far surpassing that of the average development (Table 2.). The growing importance of the tourist industry has been demostrated by the fact, that in 1964 the grovernment declared the tourist industry an independent branch of national economy.

With the increase in foreign tourist traffic, the receipts also have increased (Table 3.).

Table 3.

THE RECEIPTS trom the FOREIGN TOURIST TRAFFIC

(millions of exchange rate Forints)

$\begin{array}{rrrr}\text { Year } & \text { Receipts } & \text { Expenditure } & \text { Balance } \\ & & & \\ 1958 & 41,1 & 46,8 & 5,7 \\ 1960 & 60,6 & 60,3 & -145,3 \\ 1965 & 328,4 & 183,1 & \cdot 143 \\ 1968 & 453,2 & 218,5 & \cdot 234,7 \\ 1969 & 609.4 & 258,8 & \cdot 350,6\end{array}$

\section{Importance of the Balaton in the tourist industry}

The Balaton is a particularly attractive and valuable tourist center. It is the largest lake in Central Europe, the weather, in the area is exceptionally pleasant, and the warm waters are believed to have medical benefits. An addition it is quite shallow and therefore it is very suitable for swimmers and for families with children. The environs of the Balaton are the most important, most frequented areas for both the domestic and foreign tourist trade even though the main season of recreation lasts not more 
than three months. The total period of the resort season including the early (May) and late (September, October) months is one half a year. Almost two-thirds of the accomodations (71.000 in 1968) used for organized holidays of trade unions, different entreprises and institutions are situated in the Balaton area. The number of persons assigned to resort houses under management of the above mentioned organizations was 708.535 in 1968 and the visitors' days spent in these accomodations totalled 8.2 million in 1968. In spite of the relatively short recreation season, this area is much more important than the other recreation areas of the country (Table 4).

Table 4.

DISTRIBUTION of the TOURIST TRADE in SUBSIDIZED RESORT FACILITIES ( $\%$ )

$\begin{array}{ccccc}\begin{array}{c}\text { Accomo- Guests } \\ \text { dations }\end{array} & \begin{array}{r}\text { Gues! } \\ \text { days }\end{array} & \begin{array}{c}\text { Accomo- Guests } \\ \text { dations }\end{array} & \begin{array}{l}\text { Guest } \\ \text { days }\end{array} \\ 1960 & & & 1968\end{array}$

$\begin{array}{lrrrrrr}\text { Balaton } & 59 & 53 & 54 & 60 & 51 & 54 \\ \text { Velence lake } & 1 & 1 & 1 & 1 & 1 & 1 \\ \text { Budapest } & 9 & 8 & 5 & 7 & 7 & 4 \\ \text { Danube-bend } & 8 & 9 & 8 & 7 & 9 & 8 \\ \text { Mátra-Bukk Mts. } & 9 & 14 & 15 & 8 & 12 & 13 \\ \text { Sopron Kószeg } & 2 & 3 & 4 & 2 & 3 & 3 \\ \text { Other areas } & 12 & 12 & 13 & 15 & 17 & 17 \\ \text { Total. } & 100 & 100 & 100 & 100 & 100 & 100\end{array}$

In addition, almost half of the accomodations in quarters of public utility - hotels, motels, campings, paying guest service - are located in

Table 5 .

DISTRIBUTION OF TOURISTS IN NON-SUBSIDIZED

VACATION FACILITIES $(\%)$

Accomodations Guests Guest days

$\begin{array}{lllllllll}1960 & 1965 & 1968 & 1960 & 1965 & 1968 & 1960 & 1965 & 1968\end{array}$

$\begin{array}{lrrrrrrrrr}\text { Balaton } & 33 & 50 & 43 & 11 & 16 & 15 & 23 & 29 & 29 \\ \text { Budapest } & 14 & 15 & 15 & 28 & 28 & 28 & 26 & 27 & 26 \\ \text { Danube-bend } & 3 & 2 & 2 & 3 & 2 & 4 & 3 & 2 & 4 \\ \text { Orher areas } & 50 & 33 & 40 & 58 & 54 & 53 & 48 & 42 & 41 \\ \text { Total } & 100 & 100 & 100 & 100 & 100 & 100 & 100 & 100 & 100\end{array}$


AUSTRIA

SZOMBATHELY
CZECHOSLOVAKIA

SOPRON GYÕR PÁPA KOMÁROM

II.

III.

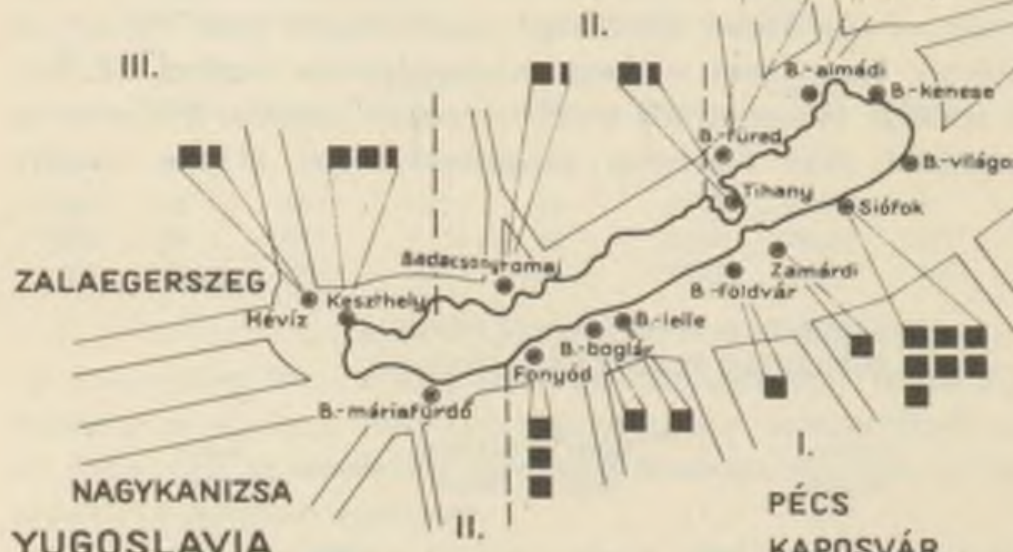

SZEKSZÁRD

E=5000 PERSONS

YUGOSLAVIA

Fig. 1. Distribution of the weekend traffic directed to the Lake Balaton, according to centres of issue, to countries and to holiday resorts. The Roman numerals show the resort district of the southern and northern shore respectively

the Balaton. Although only one-sixth of the persons staying in quarters of public utility had accomodations in the Balaton area, the total number of visitors' days spent in the area amounted to almost one-third of the total.

The predominant proportion of private vacation homes likewise can be found along the shores of the Balaton. In 1968 nearly 200.000 persons vacationed in private flats and villas in the Balaton area. Similarly, the Balaton was the final destination of a substantial proportion of the weekend excursionists. In the second half of the 1960 s 140.000 to 170.000 persons arrived at the Balaton by train or by car during the summer weekends (Figure 1).

Foreigners also have visited this resort in ever increasing numbers. In 1960 only one-seventh of the foreigners visiting Hungary spent some time in one of its resorts whereas in the summer 1968 one quarter of a million of foreigners vacationed at the Balaton. Thus every fourth visitor at the Balaton was a foreigner. Since between 1960 and 1968 the number of visitors staying at the lake on weekdays more than doubled (1.2 million

Fig. 2. Population and the unprovided visitors of the Balaton resort district (B) and Fts important holiday resorts $(A)$ in the 6 to 8 th month on the week-ends. $-1=$ Resident population: 2 = Permanently staying visitors; $3=$ Weekend traffic 


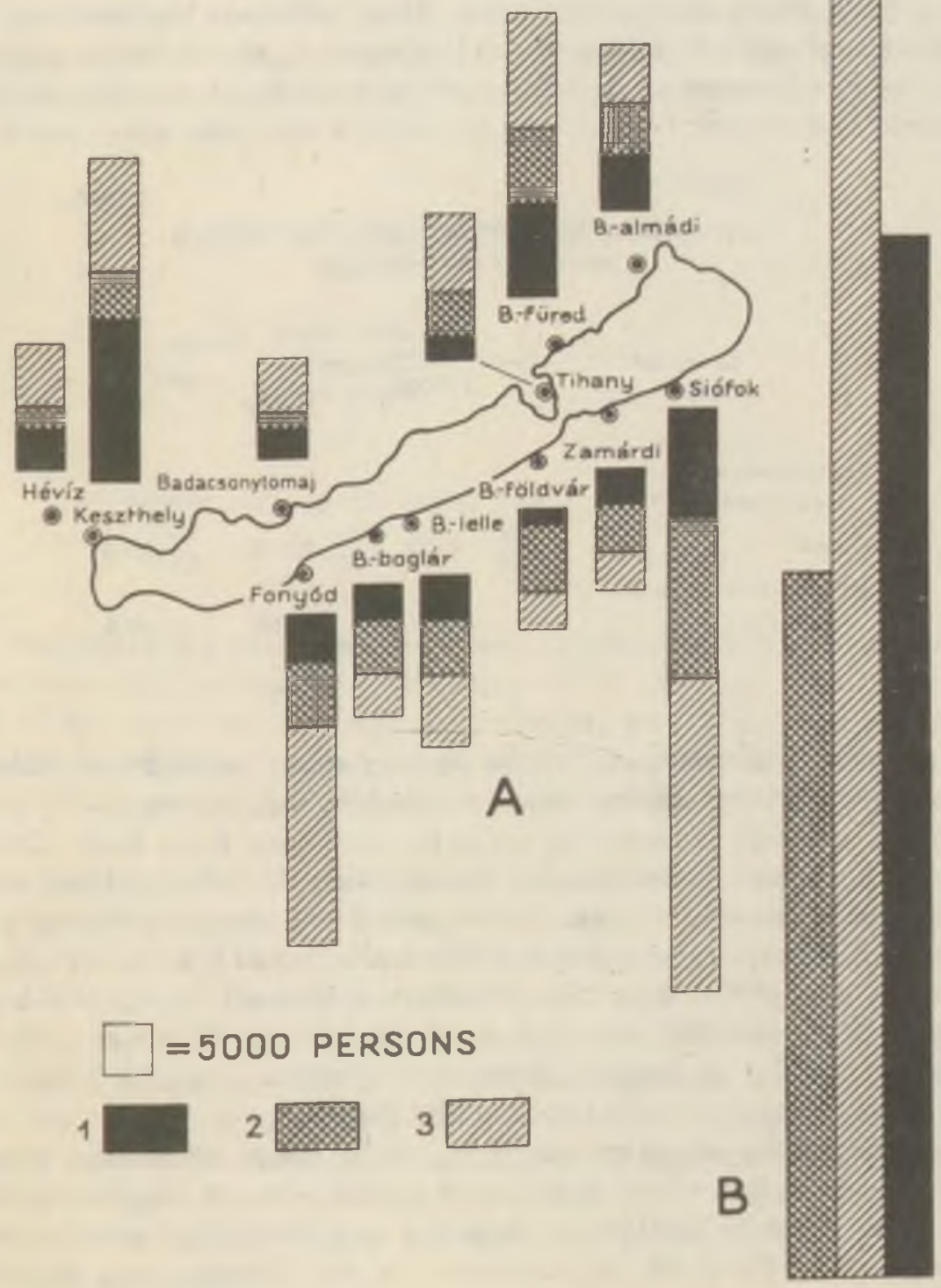


in 1968 plus to the 110.000 permanent inhabitants) accomodations for an additional 160.000 persons had to be provided and their different demands satisfied. In weekends the number af persons needing accomodation approached half a million (Figure 2).

In order to be able to satisfy the growing demands of the visitors at the holiday resorts several billion Forints have been allotted to further development of the Balaton resort district. These investments have come from many sources including the state, the trade unions, industries etc. In designating the direction, character area etc. of the development several factors were taken into consideration. They included: the optimum areal distribution of natural potentialities, the capacity of the resort, the resort area, the development of its infrastructure, transportation systems, and its economic importance. The various interests in the area were coordinated

Table 6.

NEW TOURIST ACCOMODATIONS CONSTRUCTED

BETWEEN 1960 and 1968

Hungary

(1000)

Trade Union enterprise resort homes

Hotels

Other quarters of public utility

Total

$\begin{array}{rrr}18570 & 11557 & 62,2 \\ 7678 & 2312 & 30,5 \\ 69130 & 34165 & 49,4 \\ 95378 & 48034 & 50,3\end{array}$

Balaton

(1000)

$\%$

62,2

0,5

9,4

50,3

and a complex development of the various resort centres and recreation areas began. First of all the reception capacity was increased. In addition a number of large restaurants, espressos etc. have been built. Considerable amounts were spent for the development of infrastructure, and the reclamation of eroded slopes. In this period the reconstruction of railway lines and highways surrounding the Balaton or leading to it was begun.

A large part of the recreation facilities constructed in Hungary between the years 1960 and 1968 was built near the Balaton. One half of the total reception capacity is located there. The reception capacity of the resort district rose almost threefold to 116.900 (Table 6).

The ratio of the reception capacities of the trade union and enterprise resort homes to that of the quarters of public utility changed considerably during the 1960s. In 1960 the trade union and enterprise resort homes had three-fourth of the total accomodations in the Balaton area. In 1968 as 
a result of a vigorous development program, almost two-thirds of the accomodations were in the quarters of public utility (Table 7).

More than half (53 to 68 percent) of the accomodations in the Balaton area can be found on the southern Coast.

Great care also was taken to develop camping facilities and to provide accomodations for paying guests. By locating camping grounds (ranked in the first class by international standars) on the "empty" shores between the more important resort towns, the demands of the visitors for meals, purchases, amusement, motor boats, rowing, yachting etc. could be solved easier and with a minor financial input. This policy also helped to link the various towns around the lake. By this means the supply not only of the camping grounds of the resort-centres has been raised to a higher level.

Table 7.

TOURIST RECEPTION CAPACITY of the BALATON DISTRICT

$\begin{array}{cccc}\text { Year } & \begin{array}{c}\text { Trade Union } \\ \text { and entreprise } \\ \text { vacation homes } \\ \%\end{array} & \begin{array}{c}\text { Hotels } \\ \%\end{array} & \begin{array}{c}\text { Number of } \\ \text { Accomodations }\end{array} \\ & & & \\ 1960 & 74,5 & 25,5 & 41673 \\ 1965 & 49,5 & 50,5 & 78367 \\ 1968 & 36,4 & 63,6 & 116900\end{array}$

The majority of the new hotels was built in places with a well developed infrastructure. Particular care was devoted to assuring that a proper section of the shore line and adequate services would be available to the new hotels. In addition to luxury hotels others have been built in increasing numbers which are accessible to native and foreign visitors with average incomes.

In the second half of the 1960s a new concept was introduced in hotel construction. Now hotels are being constructed which can be utilized in the early and late off-seasons as well as in the summer, and can even be operated throughout the whole year. Several hotels with a total of 1000 accomodations are in operation in the resort-district during the whole year.

In this period between 1960 and 1968 a few thousand private villas were built in the resort district. There has been a rapid decrease of suitable lake-shore construction sites. For this reason the builders more and more are constructing houses with from 50 to 100 flats. These building are being located in areas already provided with public utilities where the tourist traffic is heavy. 
Trade unions and enterprises mostly built their new establishments beside units in already operation. In this way they could increase their services while minimizing maintenance expenses.

The tourist traffic in the Balaton district has risen with 10 to 15 percent each year. The recreation facilities of this area had 790.000 visitors in 1965 - twice the number it served in 1960. The total number of visitors was one million. The number of visitors' days also has grown twofold and approches 9 millions. The tourist traffic in the resort district for the year 1968 far exceeded one million, since in the summer months alone nearly one million persons vacationed on the lake (Table 8 ).

Table 8.

THE TOURIST TRADE on the NORTHERN and SOUTHERN SHORES of the BALATON ${ }^{x}$

Index: $1160=100$

$\begin{array}{ccccccc}\begin{array}{c}\text { Southern } \\ \text { shore }\end{array} & \begin{array}{c}\text { Rest houses } \\ \text { of Trade } \\ \text { Unions and } \\ \text { onterprises }\end{array} & \text { Hotels } & \begin{array}{c}\text { Camping } \\ \text { grounds }\end{array} & \begin{array}{c}\text { Paying } \\ \text { guest- } \\ \text { service }\end{array} & \begin{array}{c}\text { Private } \\ \text { summer } \\ \text { residences }\end{array} & \text { Total } \\ 1960 & 100,0 & 100,0 & 100,0 & 100,0 & 100,0 & 100,0 \\ 1965 & 116,0 & 185,0 & -775,0 & 311,0 & 208,0 & 201,0 \\ 1968 & 122,0 & 197,0 & 770,0 & 357,0 & 287,0 & 228,0 \\ \text { Northern } & & & & & & \\ \text { shore } & 100,0 & 100,0 & 100,0 & 100,0 & 100,0 & 100,0 \\ 1960 & 136,0 & 98,0 & 408,0 & 432,0 & 265,0 & 175,0 \\ 1965 & 143,0 & 131,0 & 513,0 & 740,0 & 367,0 & 246,0 \\ 1968 & & & & & & \\ \text { Balaton } & & & & & & \\ \text { total } & 100,0 & 100,0 & 100,0 & 100,0 & 100,0 & 100,0 \\ 1960 & 123,0 & 133,0 & 588,0 & 346,0 & 225,0 & 206,0 \\ 1965 & 124,0 & 156,0 & 612,0 & 433,0 & 297,0 & 234,0\end{array}$

\footnotetext{
Xince 80 to 95 percent of the traffic is concentrated in the summer months (June, July, . August) the data in the tables contain only the traffic of visitors for the summer months without weekend excursionists.
}

The southern shore attracted more than 60 percent of the total traffic. In 1960 the resort of the southern shore were visited by 86.000 more persons than visited the northern shore, while in 1968 the number rose to 183.000 .

Taking into account only the traffic of the summer months, in 1960 there were 1900 visitors to every kilometer of the total shore length, while in 1968 this number approached 5000 (Figure 3). 


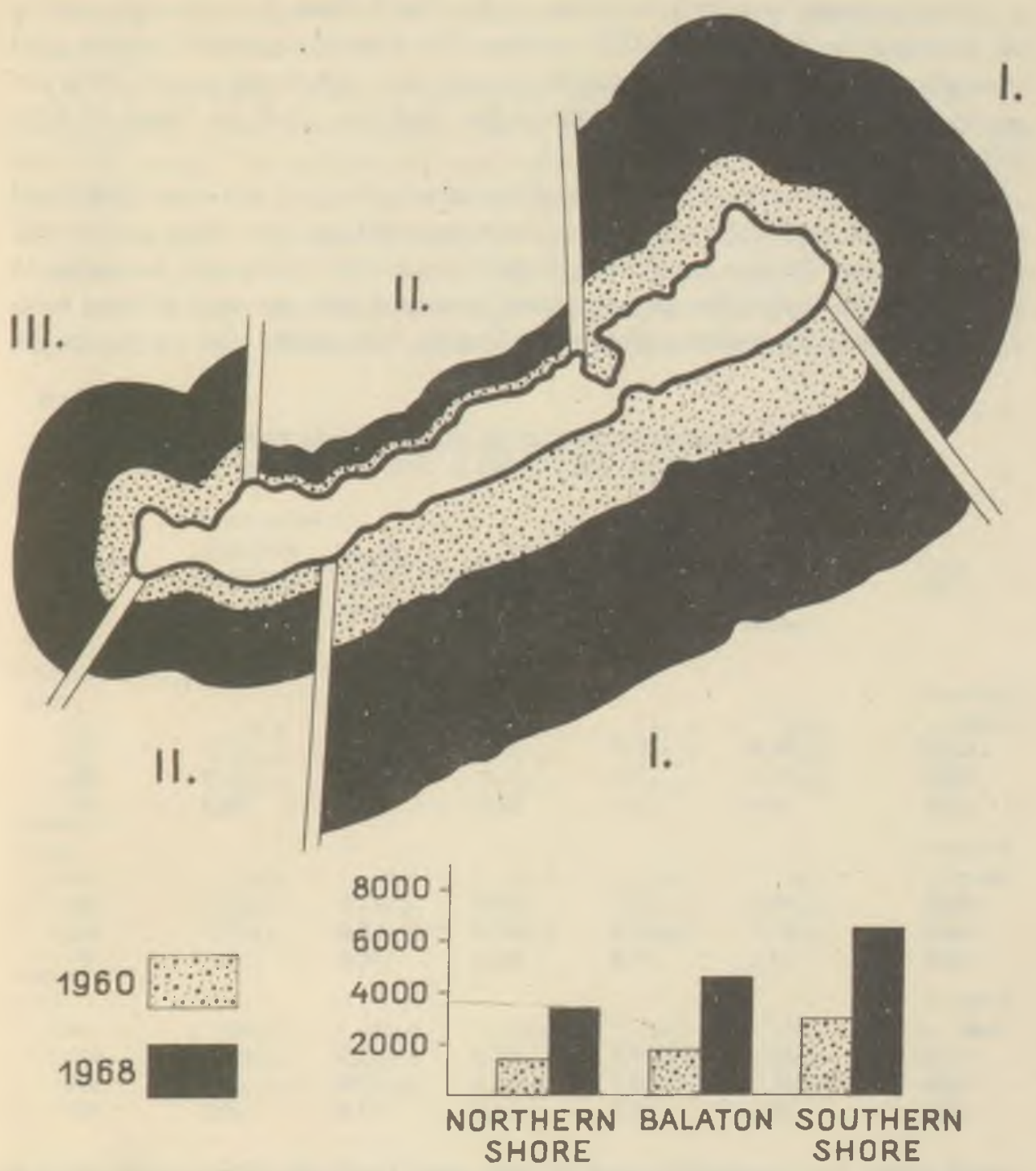

Fig. 3. Number of guests per one $\mathrm{km}$ lake-shore in the resort regions of the southern (I-II) and northern (I-II-III) shore in 1960 and 1968

Among the resort centres, the traffic of Siofok is the largest. In summer months (not counting weekend visitors) nearly 200.000 guests were received there. These guests together with the weekend visitors exceeded half a million. On an average summer day Siófok had one and a half times more visitors (about 20.000) than its permanent population. On the weekends the number is increased by about 25.000 to 30.000 . Therefore, 
on the weekends a supply of a far higher level than the average had to be provided for 65.000 to 70.000 persons. The most frequented centres and recreation areas can be regarded as already saturated particularly on weekends, with regard to possibilities for reception and the level of their infrastructures.

The types of visitors who frequent the area changed between 1960 and 1968. In 1960, half of their visitors was received by the trade union and enterprise rest homes and one seventh by hotels. Campers brought 11 percent of the trade, the paying guest service 6 percent and private summering houses 16 percent (Table 9). During this period the traffic in the

Table 9.

In the SUMMER MONTHS DISTRIBUTION of the TOURIST TRAFFIC in the BALATON RESORT DISTRICT ACCORDING to CHARACTER of RECEPTION, \%

\begin{tabular}{|c|c|c|c|c|c|}
\hline Year & $\begin{array}{l}\text { Trade Union } \\
\text { and enter- } \\
\text { prise rest- }\end{array}$ & Hotels & $\begin{array}{l}\text { Camping } \\
\text { grounds }\end{array}$ & $\begin{array}{l}\text { Paying } \\
\text { guest } \\
\text { service }\end{array}$ & $\begin{array}{c}\text { Private } \\
\text { summer } \\
\text { houses }\end{array}$ \\
\hline
\end{tabular}

\begin{tabular}{|c|c|c|c|c|c|c|}
\hline $\begin{array}{l}\text { Southern } \\
\text { shore }\end{array}$ & & & & & & \\
\hline 1960 & 56,6 & 8,3 & 8,3 & 8,1 & 18,7 & 100 \\
\hline 1965 & 31,4 & 7,3 & 30,0 & 12,0 & 18,0 & 100 \\
\hline 1968 & 30,4 & 7,1 & 28.1 & 12,2 & 22,2 & 100 \\
\hline $\begin{array}{l}\text { Northern } \\
\text { shore }\end{array}$ & & & & & & \\
\hline 1960 & 46,5 & 22,2 & 15,3 & 3,5 & 12,5 & 100 \\
\hline 1965 & 31,7 & 11,2 & 32,0 & 8,0 & 17,1 & 100 \\
\hline 1968 & 27,1 & 11,9 & 31,9 & 10,5 & 18,6 & 100 \\
\hline $\begin{array}{l}\text { Balaton } \\
\text { total }\end{array}$ & & & & & & \\
\hline 1960 & 52,9 & 13,5 & 10,9 & 6,3 & 16,4 & 100 \\
\hline 1965 & 31,5 & 8,7 & 31,3 & 10,5 & 18,0 & 100 \\
\hline 1968 & 29,1 & 8,9 & 29,6 & 11,6 & 20,8 & 100 \\
\hline
\end{tabular}

trade union and enterprise rest houses rose by 60.000 , their proportion of the total visitors' traffic decreased considerably to less than one-third. In 1968 the percentage of visitor's staying in hotels decreased with 8.9 percent. The number of tourists enjoying the paying guest service and private summer residences increased substantially during the 1960s. In 1968 these categories attracted 12 and 21 percent respectively of the total traffic a more than twofold increase.

The number of campers has shown the largest increase. It increased from 46.000 to 267.000 during the 1960 s and the campsites received far more visitors than the hotels and the paying guest service together. The 
percentage of campers in the total traffic in 1968 was more than three times higher than it was in 1960.

On the northern shore 3 recreation areas developed which can be distinguished from one another while on the southern shore there are only two areas. The majority of new visitors in the south went to the resort centres of the recreation area extending from Fonyod to Siofok which is well provided with accessory establishments. Therefore the difference in the reception capacity and number of visitors in the recreation area extendig east from Fonyód to Siófok and that situated to the west became quite accentuated. The recreation area between these two resorts includes 73

Table 10.

DISTRIBUTION of the TOURIST TRAFFIC, \%

\begin{tabular}{|c|c|c|c|c|c|}
\hline Year & $\begin{array}{l}\text { Trade Union } \\
\text { and enter- } \\
\text { prise rest- } \\
\text { houses }\end{array}$ & Hotels & $\begin{array}{l}\text { Camping } \\
\text { grounds }\end{array}$ & $\begin{array}{c}\text { Paying } \\
\text { guest } \\
\text { service }\end{array}$ & $\begin{array}{l}\text { Private } \\
\text { summer } \\
\text { houses }\end{array}$ \\
\hline
\end{tabular}

\section{Southern}

shore

1960

1965

1968

66,9
63,4
63,4

48,4

47,6

62,6

53,6

57,7

79,1
72,2
64,4

71,4

65,5

64,6

62,5

63,7

60,7

Nor thern

shore

\section{0}

1965

33,1

36,6

36,6

$$
\begin{aligned}
& 61,6 \\
& 46,4 \\
& 51,9
\end{aligned}
$$

52,4

37,4

42,3

20,9
27,8
35,6

38,6

37,5

34,5

36,3

35,4

39,3

\section{Balaton}

total

1960

1965

1968

100,0
100,0

100,0

100,0

100,0

100,0
100,0
100,0

100,0
100,0
100,0

100,0

100,0

100,0

100,0

100,0

100,0

percent of the southern shore line, and attracted 89 percent of the visitors. Thus of the 547.000 visitors at the southern shore almost 500.000 spent their summer holidays in this area. Out of the nine most frequented resorts in the Balaton area six can be found on this section of the southern coast. In 1968 these resort centres - Siófok, Fonyód, Balatonföldvár, Balatonlelle, Zamárdi and Balatonboglár - had more visitors than all of the resorts on the northern shore. All of the hotels on the southern shore can also be found in this resort zone, and most of them are located in Siofok.

On the northern coast three recreation areas share in the traffic of visitors. Most of the visitors were received by the recreation area extending 
from Tihany to Balatonvilágos. This area attracted 46 percent of the total for the northern shore. Among its resorts Balatonfüred is the most important. It is in second place after Siofok with the largest traffic of the Balaton district. This centre also is a health-resort which operates during the whole year. In 1968 it received 80.000 visitors. The rapidly developing Balatonalmádi and Tihany areas had over 50.000 visitors each. The Tihany peninsula rich in natural beauties and historical relics is one of the most favoured excursion-places in the Balaton resort district. It is visited yearly by several hundred thousands excursionists.

The central recreation zone - extending from Aszofō to Szigliget - attracts not more than 19.5 percent of the visitors, although it occupies 40 percent of the shore line.

Finally the recreation area situated between Balatonederics and Keszthely situated on the western part of the northern shore occupies only 15 percent of the shore line but it attracts more than one quarter of the tourist traffic. Four fifths of its visitors were received by its two resorts, Keszthely and Héviz, the famous health resort operated during the whole year.

\section{Foreign tourist traffic in the resort district}

In the period between 1960 and 1968 foreigners visited the Balaton in constantly increasing numbers. The foreign tourist traffic of the district rose 64.7 percent and in 1968 totalled 258.501. Eighty-five percent of the foreigners visited the lake in the summer months. The great majority of them were from the socialist countries (Table 11). Those who came from Western countries, however, spent the longest amount of time at the Balaton.

More than half $(121.000)$ of the visitors who arrived from socialist countries came from Czechoslovakia. The second place (42.000) was occupied by the German Democratic Republic, the third by Poland (11.000). The Soviet

Table 11.

THE FOREIGN TOURIST TRAFFIC Of the BALATON RESORT DISTRICT

Arrived from

\% of visitors

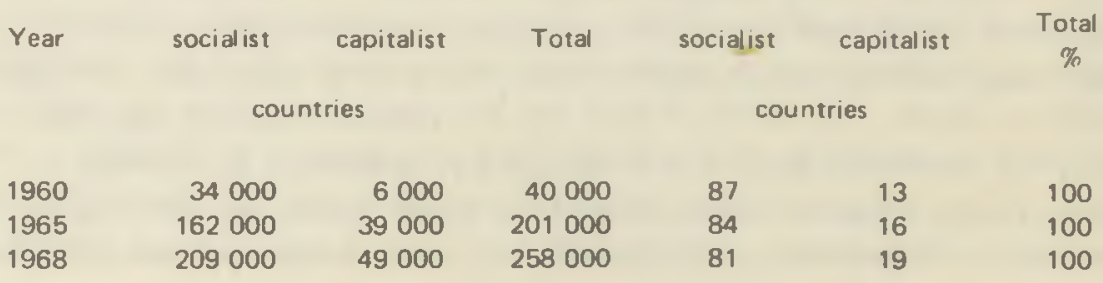


Union and Yugoslavia sent only 6.700 and 4.300 visitors respectively. Among the capitalistic countries the German Federal Republic took first place with 13.000 visitors, the neighbouring Austria was in second place with 8900 visitors. The other European countries, - France, Italy, the United Kingdom and the Scandinavian countries as well as the States and Canada - had 3.000 to 15.000 visitors each.

The distribution of foreign visitors between the two coasts was similar to that of the total visitors' traffic and the largest percent went to the southern coast. Siöfok, Balatonfüred and Balatonföldvár were favourite resorts of the foreigners. Fifty-eight percent of the non-Hungarian tourists stayed in camp grounds; twenty-eight percent stayed in hotels; and fourteen percent used the paying guest service. During the summer of 1968 threefourths of all the visitors in the first class camp grounds and hotels were foreigners, while one-third of those who had quarters in the paying guest service were foreign.

In summary the period between 1960 and 1968 saw a considerable change and advance in the Balaton resort district. The reception capacity increased in response to a growing demand and became differentiated at the same time. The ratio of organized holidays at subsidized prices to visitors staying in quarters of public utility has changed. In the second half of the 1960s a large percentage of guests used nonsubsidized facilities. In addition the reception capacity of the hotels has increased considerably and simultaneously the available services have been greatly expanded. The rapid increase in the number of foreign visitors points to the fact that the attracting potentialities of the Balaton playes a constantly growing role in enlarging Hungarys' foreign tourist trade.

The Balaton resort district consolidated its leading place as an attraction for Hungarian vacationers and remained the most important recreation area. The foreign tourist traffic undoubtedly is the most important function of the Balaton resort district. This main function will only increase in the future. The second regional plan for the development of the resort district was adopted in 1970. The tasks contained in the plan are: development of settlements, resort centres, and recreation areas; enlargement of the capacity of service establishments; building of regional waterworks; solution of the sewage disposal problems; reclamation of eroded shore areas as well as construction of new roads and railways. These objectives will be gradually realized in several plan periods. In the first period (between 1971 and 1975) about seven billion Forints will be spent for the development. According to the plan, in summer months in each day about $450.000 \mathrm{rec}$ reating visitors will be able to stay in the resort district, in addition to the permanent population of 150.000 inhabitants. When the week-end excur- 
sionists - an estimated 200.000 to 250.000 persons - are added to this number an adequate accomodation and supply will have to be provided along the Balaton for nearly one million persons. After realization of these goals the tourist trade in the Balaton should substiantially increase.

\section{BIBLIOGRAPHY}

Bacsó, N. (1959). Magyarország éghajlata (Climate of Hungary). - Budapest: Akadémiai Kiadó.

Balatonfejlesztés 20 éves tervjavaslata (Twenty years' plan proposal for development of the Balaton). - Budapest: Balatoni Intézō Bizottság, (1962).

Balatoni Kōzponti Fejlesztési Program Múszaki-Gazdasági Koncepciōjo (Technical-economic conception of the Central Development Program for the Balaton). - Budapest: Epitesügyi è Vỏrosfejlesztési Minisztérium, (1968).

Gertig, B. (1962). Somogy megye mezŏgazdasági földrajza (Agricultural geography of Somogy County). - Földr. Közl. 1, Vol. 10.

Gertig, B. (1964). A balatoni üdülő́körzet zöldségellátásának földrajzi problémái (Geographical problems of the vegetoble supply of the recreation region of Lake Balaton). Földr. Ert. 1, Vol. 13.

Gertig. B. (1965). A Balaton-part fejlesztésének kérdései (Prablems of developing the Balaton coast). - Kaposvár.

Gertig. B. (1966). A Balaton dẻli (somogyi) partja üdülốvendég-forgalmának alakulása (Trend of the tourist traffic of the southern shore of Lake Balaton (Somogy Region)). Földr. Ert. 4, Vol. 15.

Gertig, B. (1966). A Balaton idegenforgalma (Foreign tourist traffic of the Balaton). Jelenkor (Pécs), 7, Vol. 9.

Gertig. B. A balatoni ūdülōkōrzet idegenforgalma ès ellátósának fôldrajzi problémái (Foreign tourist:traffic of the Balaton resort district and geographical problems of its supply). - Kézirat (Manuscript).

Horvàth, T. (1960). A Balaton üdülôvendég-forgalma (Traffic of the recreating visitors of the Balaton). - Megyei ès Városi Statisztikai Ertesitõ 1, 5, Vol. 10.

Jelentês az 1962. évi balatoni idényröl (Report on the Balaton season of 1962). - Kaposvár: KSH Somogy megyei ès Veszprẻm megyei lgazgotósága, (1963).

Idegenforgalmi adattảr (Collection of data of foreign tourist traffic). - Budapest: KSH, (1966).

Idegenforgalmi adatok (Data of foreign tourist traffic). - Budapest: KSH, (1968).

Belkereskedelmi Dokumentáció II. köt. (Home-trade documentation. Vol. II). - Budapest: $\mathrm{KSH},(1961)$.

Kovács, L. and Takács, J. (1966). Az idegenforgalom alakulása ès fejlōdése Magyarorszá. gon 1945-1965 (Trend and development of the foreign tourist traffic in Hungary 19451965). - Budapest: Panoráma, (1966).

Központi Statisztikai Hivatal Somogy megyei ès Veszprém megyei lgazgatóságának jelentése az 1965. èvi balatoni idènyröl (Report of the Directorate of the Central Statistical Office in Somogy County and Veszprem County on the Bolaton season of 1965). Budapest: KSH Somogy megyei ès Veszprèm megyei lgazgatósóga, (1966).

III, Idegenforgalmi Kollokvium, OIH (III. Foreign Tourist Traffic Colloquium, OIM). - Budapest: Panoràma, (1967). 
Lénárt, K. and Mizser, J. (1962). A Balaton északi partjấn fekvố üdūlőhelyek vendẻgforgalma ès áruellátása (Visitors' traffic and commodity supply of resort places situated on the northern coast of the Balaton). - Megyei ès Városi Statisztikai Értesitó 7, Vol. 12.

Markos, B. and Kolacsek, A. (1961). Idegenforgalom (Foreign tourist traffic). - Budapest: Kōzgazdasági és Jogi Könyvkiadó.

Statisztikai évkönyv 1961 (Statistical yearbook 1961). - Budapest: KSH, (1962).

Statisztikai évkōnyv 1965 (Statistical yearbook 1965). - Budapest: KSH, (1966).

Statisztikai évkönyv 1968 (Statistical yearbook 1968). - Budapest: KSH, (1969).

Somogy megye statisztikai èvkönyve 1968 (Statistical yearbook of Somogy County 1968). Kaposvár: KSH Somogy megyei lgazgatósógo (1968).

Veszprém megye statisztikai évkônyve 1965 (Statistical yearbook of Veszprém County 1965).

- Veszprém: KSH Veszprém megyei Igazgatósága (1968). 
Editor: Geographical Research Institute of the Hungarian Academy of Sciences Responsible editor: Gy. Enyedi 
